\title{
Ion Exchange Testing with SRF Resin FY 2012
}

RL Russell

DE Rinehart

RA Peterson

June 2013

\section{Pacific Northwest}

NATIONAL LABORATORY

Proudly Operated by Battelle Since 1965 


\title{
DISCLAIMER
}

This report was prepared as an account of work sponsored by an agency of the United States Government. Neither the United States Government nor any agency thereof, nor Battelle Memorial Institute, nor any of their employees, makes any warranty, express or implied, or assumes any legal liability or responsibility for the accuracy, completeness, or usefulness of any information, apparatus, product, or process disclosed, or represents that its use would not infringe privately owned rights. Reference herein to any specific commercial product, process, or service by trade name, trademark, manufacturer, or otherwise does not necessarily constitute or imply its endorsement, recommendation, or favoring by the United States Government or any agency thereof, or Battelle Memorial Institute. The views and opinions of authors expressed herein do not necessarily state or reflect those of the United States Government or any agency thereof.

\author{
PACIFIC NORTHWEST NATIONAL LABORATORY \\ operated by \\ BATTELLE \\ for the \\ UNITED STATES DEPARTMENT OF ENERGY \\ under Contract DE-AC05-76RL01830
}

Printed in the United States of America
Available to DOE and DOE contractors from the Office of Scientific and Technical Information, P.O. Box 62, Oak Ridge, TN 37831-0062; ph: (865) 576-8401 fax: $(865) 576-5728$
email: reports@adonis.osti.gov
Available to the public from the National Technical Information Service 5301 Shawnee Rd., Alexandria, VA 22312 ph: (800) 553-NTIS (6847) email: orders $a$ ntis.gov $<$ http://www.ntis.gov/about/form.aspx> Online ordering: http://www.ntis.gov


PNNL-21645

WTP-RPT-223, Rev 0

\section{Ion Exchange Testing with SRF Resin FY 2012}

RL Russell

DE Rinehart

RA Peterson

June 2013

Test Specification: 24590 PTF-TSP-RT-09-002, Rev. 0

Test Plan: TP-RPP-WTPSP-002, Rev. 3.0

Test Exceptions: 24590-PTF-TEF-RT-11-00003, Rev. 0 and

24590-PTF-TEF-RT-11-00004, Rev. 0

R\&T Focus Area: Pretreatment

Test Scoping Statement: 24590-WTP-PL-RT-07-0002, Rev 0; M6-3

Prepared for the U.S. Department of Energy

Under Contract DE-AC05-76RL01830

Pacific Northwest National Laboratory

Richland, Washington 99352 
WTP-RPT-223 Rev 0

\section{Completeness of Testing}

This report describes the results of work and testing specified by Test Specification, 24590-PTF-TSP-RT-09-002, Rev 0, Test Exception 24590-PTF-TEF-RT-11-00003, Rev. 0, and Test Plan TP-RPP-WTPSP-002, Rev. 3.0. The work followed the quality assurance requirements outlined in the Test Specification and Test Plan. The descriptions provided in this report are an accurate account of both the conduct of the work and the data collected. Test Plan results are reported. Also reported are any unusual or anomalous occurrences that are different from expected results. The test results and this report have been reviewed and verified.

Approved:

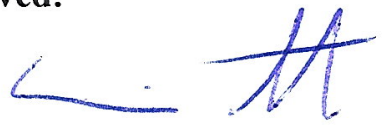

Reid A Peterson, Manager

WTP R\&T Support Project

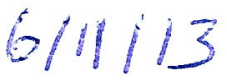

Date 


\section{Testing Summary}

Ion exchange using spherical resorcinol-formaldehyde (SRF) resin has been selected by the U.S. Department of Energy's Office of River Protection (DOE-ORP) for use in the Pretreatment Facility (PTF) of the Hanford Tank Waste Treatment and Immobilization Plant (WTP) and for potential application in at-tank deployment. Numerous studies have shown SRF resin to be effective for removing ${ }^{137} \mathrm{Cs}$ from a wide variety of actual and simulated tank waste supernatants (Adamson et al. 2006; Blanchard et al. 2008; Burgeson et al. 2004; Duignan and Nash 2009; Fiskum et al. 2006a; Fiskum et al. 2006b; Fiskum et al. 2006c; Fiskum et al. 2007; Hassan and Adu-Wusu 2003; King et al. 2004; Nash et al. 2006). Prior work at the Pacific Northwest National Laboratory (PNNL) has focused primarily on the loading behavior for 4 to $6 \underline{\mathrm{M}}$ Na solutions at 25 to $45^{\circ} \mathrm{C}$. Recent proposed changes to the WTP ion exchange process baseline indicate that loading may include a broader range of sodium molarities ( 0.1 to $8 \underline{\mathrm{M}})$ and higher temperatures $\left(50^{\circ} \mathrm{C}\right)$ to alleviate post-filtration precipitation issues.

This report discusses ion exchange loading kinetics testing activities performed in accordance with Test Plan TP-WTPSP-002, Rev. $3.0^{1}$, which was prepared and approved in response to the Test Specification 24590-PTF-TSP-RT-09-002, Rev. 0 (Lehrman 2010) and Test Exception 24590-PTF-TEF-RT-11-00003, Rev. 0 (Meehan 2011). This testing focused on column tests evaluating the impact of elevated temperature on resin degradation over an extended period of time and batch contacts evaluating the impact on Cs loading over a broad range of sodium concentrations (0.1 to $5 \underline{\mathrm{M}})$. These changes may be required to alleviate post-filtration precipitation issues and broaden the data range of SRF resin loading under the conditions expected with the new equipment and process changes.

\section{Objectives}

The test objectives included the following:

- Determine the impact of 0.1 to $5 \underline{\mathrm{M}}$ sodium, 0.005 to $0.05 \underline{\mathrm{M}}$ potassium, 0.1 to $1 \underline{\mathrm{M}}$ free hydroxide, and 5E-06 to 5E-03 $\underline{\mathrm{M}}$ cesium on the Cs ion exchange loading of the SRF resin at 25,35 , and $50^{\circ} \mathrm{C}$.

- Determine the impact of temperature $\left(25,35,40\right.$, and $\left.45^{\circ} \mathrm{C}\right)$ on $\mathrm{Cs}$ ion exchange kinetics and loading of the SRF resin.

- Determine the impact of temperature $\left(45,50,55\right.$, and $\left.60^{\circ} \mathrm{C}\right)$ on Cs ion exchange loading of the SRF resin during extended (>30-day) exposure to flowing waste simulant.

Table S.1 provides test objectives and results for the ion exchange loading kinetics testing task.

\footnotetext{
${ }^{1}$ Russell RL. 2010. Cesium Ion Exchange Simulant Testing in Support of M6. TP-WTPSP-002, Rev. 3.0, Pacific Northwest National Laboratory, Richland, Washington.
} 
Table S.1. Summary of Test Objectives and Results

\begin{tabular}{|c|c|c|}
\hline Test Objective & $\begin{array}{c}\text { Objective } \\
\text { Met? }\end{array}$ & Discussion \\
\hline $\begin{array}{l}\text { Determine the impact of } 0.1 \text { to } \\
5 \underline{\mathrm{M}} \text { sodium, } 0.005 \text { to } 0.05 \underline{\mathrm{M}} \\
\text { potassium, } 0.1 \text { to } 1 \underline{\mathrm{M}} \text { free } \\
\text { hydroxide, and } 5 \mathrm{E}-06 \text { to } \\
5 \mathrm{E}-03 \underline{\mathrm{M}} \text { cesium on the Cs } \\
\text { loading of the SRF resin at } \\
\text { various temperatures. }\end{array}$ & Yes & $\begin{array}{l}\text { Batch loading tests were performed using simulants with } \\
\text { varying Na, OH, K, and Cs concentrations. It was found that } \\
\text { Cs loading was primarily affected by Na concentration. } \\
\text { Potassium appeared to have a varying effect on the Cs loading; } \\
\text { lower Cs concentrations had greater K effect. This was } \\
\text { expected due to the competition for the resin sites between the } \\
\text { K and the Cs. The OH concentration did not have a significant } \\
\text { effect on the resin Cs loading. The temperature effect on the } \\
\text { resin Cs loading appeared to be dependent on Na concentration } \\
\text { with the effect being greater at lower Na concentrations. At } \\
5 \underline{\mathrm{M}} \text { Na, only a slight negative effect of increasing temperature } \\
\text { was observed; however, at } 1 \underline{\mathrm{M}} \text { Na, the effect of increasing } \\
\text { temperature was much greater. These results are discussed in } \\
\text { Section } 4.3 \text {. }\end{array}$ \\
\hline $\begin{array}{l}\text { Determine the impact of } \\
\text { multiple moderate temperature } \\
\text { loading cycles on Cs ion } \\
\text { exchange kinetics and loading } \\
\text { of the SRF resin. }\end{array}$ & Yes & $\begin{array}{l}\text { Columns were loaded with a } 5 \underline{\mathrm{M}} \text { Na feed initially and then } \\
\text { cycled through several loading and elution cycles. After five } \\
\text { cycles, columns were loaded with the same } 5 \underline{\mathrm{M}} \text { Na feed as } \\
\text { used initially under the same conditions. The level of Cs } \\
\text { loading on the resin was then compared. Moderate temperature } \\
\text { cycling up to } 45^{\circ} \mathrm{C} \text { only affected the resin Cs loading slightly } \\
\text { and did not have a significant effect on the loading kinetics of } \\
\text { the resin. These results are discussed in Section } 4.2 \text {. }\end{array}$ \\
\hline $\begin{array}{l}\text { Determine the impact of } \\
\text { temperature on Cs ion exchange } \\
\text { loading of the SRF resin during } \\
\text { extended (>30-day) exposure to } \\
\text { flowing waste simulants. }\end{array}$ & No & $\begin{array}{l}\text { Ion exchange columns were held at varying temperatures from } \\
45 \text { to } 60^{\circ} \mathrm{C} \text { for } 14 \text { to } 30 \text { days with feed passing through them. } \\
\text { Simulant feed samples were taken periodically to assess the Cs } \\
\text { loading of the resin. Testing for these extended times at } \\
\text { elevated temperatures showed that resin loading capacity } \\
\text { decreased at } 45^{\circ} \mathrm{C} \text { and continually decreased with increasing } \\
\text { temperature. Column plugging was observed in all runs above } \\
45^{\circ} \mathrm{C} \text { prior to the end of the } 30 \text {-day test period. These results } \\
\text { are discussed in Section } 4.2 \text {. }\end{array}$ \\
\hline
\end{tabular}




\section{Test Exceptions}

Test Exceptions applicable to Test Plan TP-WTPSP-002, Rev. $3^{1}$ are presented in Table S.2.

Table S.2. Test Exceptions

\begin{tabular}{|c|c|}
\hline Test Exception Number & Description of Test Exception \\
\hline \multirow[t]{3}{*}{ 24590-PTF-TEF-RT-11-00003, Rev 0} & $\begin{array}{l}\text { This Test Exception was received from Bechtel National, Inc. (BNI) on } \\
\text { September } 13,2011 \text {. Two requests to expand the process limits evaluation } \\
\text { for cesium ion exchange resin were received and the outcome of earlier } \\
\text { testing temperatures at } 55^{\circ} \mathrm{C} \text { and above requires further testing to confirm } \\
\text { appropriate operating limits for WTP ion exchange. The WTP mission } \\
\text { simulations using the G2 Dynamic model have shown that the cesium ion } \\
\text { exchange process (CXP) feed stream will 'frequently' be below } 2.0 \underline{\mathrm{M}} \text { Na. } \\
\text { Therefore, the process limits were changed to evaluate cesium removal } \\
\text { performance at Na concentrations as low as } 0.71 \underline{\mathrm{M}} \text {. }\end{array}$ \\
\hline & $\begin{array}{l}\text { Also, unexpected challenges were experienced for conditions at } 55^{\circ} \mathrm{C} \text { and } \\
\text { above during cesium removal. BNI suspected that the mechanism for } \\
\text { these issues was related to the simple simulant applied during testing the } \\
\text { previous year. Therefore, they wanted to use a more complex simulant to } \\
\text { assess performance in extended } 30 \text {-day duration in solutions at and above } \\
55^{\circ} \mathrm{C} \text { in this testing. These temperature evaluations are needed to identify } \\
\text { the specific operating temperature range for SRF resin. }\end{array}$ \\
\hline & $\begin{array}{l}\text { Data on the fire safety limits for soot/particulate generation and ignition } \\
\text { temperature for the SRF resin was also requested. This is addressed in } \\
\text { report WTP-RPT-218 (Kim 2012). }\end{array}$ \\
\hline 24590-PTF-TEF-RT-11-00004, Rev 0 & $\begin{array}{l}\text { This Test Exception was received from BNI on December 22, 2011. This } \\
\text { is not applicable to the task in this report and is addressed in report } \\
\text { WTP-RPT-218 (Kim 2012). }\end{array}$ \\
\hline
\end{tabular}

${ }^{1}$ Russell RL. 2010. Cesium Ion Exchange Simulant Testing in Support of M6. TP-WTPSP-002, Rev. 3.0, Pacific Northwest National Laboratory, Richland, Washington. 


\section{Results and Performance Against Success Criteria}

The Research and Technology (R\&T) success criteria for achieving the test objectives is discussed in Table S.3.

Table S.3. Success Criteria Ion Exchange Loading Kinetics

List Success Criteria

1) Develop empirical information that allows determination of the effect of temperature and initial $\mathrm{Na}$, initial $\mathrm{K}$, initial Cs, and free $\mathrm{OH}$ ion concentrations on Cs loading capacity of the ion exchange resin.

2) Develop empirical information that allows determination of the effect of multiple moderate temperature loading cycles on the Cs kinetics and loading of the SRF resin.

3) Develop empirical information that allows determination of the impact of temperature on Cs loading of the SRF resin during extended (>30-day) exposure to flowing waste simulants.
Explain How the Tests Did or Did Not Meet the Success Criteria

This success criterion was met. The batch bottles were loaded with various compositions of simulants and SRF resin at a volumetric phase ratio of 150:1 for $72 \mathrm{hr}$. The level of Cs in the solution was measured before and after the $72 \mathrm{hr}$ and the results were compared. It was found that Cs loading was primarily affected by Na and Cs concentrations. Potassium appeared to have a varying effect on Cs loading; lower $\mathrm{Cs}$ concentrations had greater $\mathrm{K}$ effect. This was expected due to the competition for the resin sites between the $\mathrm{K}$ and the Cs. The $\mathrm{OH}$ concentration did not have a significant effect on the resin Cs loading. The temperature effect on the resin loading appeared to be dependent on Na concentration with the effect being greater at lower Na concentrations. At $5 \underline{\mathrm{M}} \mathrm{Na}$, only a slight negative effect of increasing temperature was observed; however, at $1 \underline{\mathrm{M} \mathrm{Na}}$, the effect was greater.

This success criterion was met. The columns were loaded with a $5 \underline{\mathrm{M}} \mathrm{Na}$ feed initially and then cycled through several loading and elution tests. After a total of four $10 \mathrm{hr}$ cycles and one extended cycle at elevated temperature (14 to 30 days), the column was loaded with the same $5 \underline{\mathrm{M}} \mathrm{Na}$ feed as used initially under the same conditions. The level of Cs loading on the resin was then compared to determine the effect of these variables. Moderate temperature cycling up to $45^{\circ} \mathrm{C}$ only affected the resin Cs loading slightly and did not have a significant effect on the loading kinetics of the resin.

This success criterion was partially met. The extended run tests at $55^{\circ} \mathrm{C}$ and $60^{\circ} \mathrm{C}$ that were intended to run for $720 \mathrm{hr}$ were aborted after $\sim 336 \mathrm{hr}$ due to column plugging. The extended run test at $50^{\circ} \mathrm{C}$ that was intended to run for $720 \mathrm{hr}$ was aborted after $\sim 600 \mathrm{hr}$ due to column plugging. Columns were held at varying temperatures from 45 to $60^{\circ} \mathrm{C}$ for 14 to 30 days with feed passing through them. Samples were taken periodically to assess the Cs loading of the resin. Testing for these extended times at elevated temperatures showed that the resin Cs loading decreased at $45^{\circ} \mathrm{C}$ and continually decreased with increasing temperature.

\section{Quality Requirements}

The PNNL Quality Assurance (QA) Program is based on requirements defined in the DOE Order 414.1D, Quality Assurance, and 10 CFR 830, Energy/Nuclear Safety Management, and Subpart A--Quality Assurance Requirements (a.k.a. the Quality Rule). PNNL has chosen to implement the following consensus standards in a graded approach:

- ASME NQA-1-2000, Quality Assurance Requirements for Nuclear Facility Applications, Part 1, Requirements for Quality Assurance Programs for Nuclear Facilities. 
- ASME NQA-1-2000, Part II, Subpart 2.7, Quality Assurance Requirements for Computer Software for Nuclear Facility Applications.

- ASME NQA-1-2000, Part IV, Subpart 4.2, Graded Approach Application of Quality Assurance Requirements for Research and Development.

The procedures necessary to implement the requirements are documented through PNNL's "How Do I...?” (HDI). ${ }^{1}$

The Waste Treatment Plant Support Project (WTPSP) implements an NQA-1-2000 QA Program, graded on the approach presented in NQA-1-2000, Part IV, Subpart 4.2. The WTPSP QA Manual (QA-WTPSP-0002) describes the technology life cycle stages under the WTPSP QA Plan (QA-WTPSP-0001). The technology life cycle includes the progression of technology development, commercialization, and retirement in process phases of basic and applied research and development (R\&D), engineering and production and operation until process completion. The life cycle is characterized by flexible and informal quality assurance activities in basic research, which becomes more structured and formalized through the applied R\&D stages.

The work described in this report has been completed under the QA technology level of Applied Research. WTPSP addresses internal verification and validation activities by conducting an Independent Technical Review of the final data report in accordance with WTPSP's procedure QA-WTPSP-601, Document Preparation and Change. This review verifies that the reported results are traceable, that inferences and conclusions are soundly based, and that the reported work satisfies the test plan objectives.

\section{R\&T Test Conditions}

This report summarizes the ion exchange removal of Cs from a simple waste simulant using Microbeads SRF resin, Lot 5E-370/641. The resin was sub-sampled from existing stock that had been stored under $\mathrm{N}_{2}$ at PNNL for more than 4 years in the $\mathrm{H}^{+}$-form. The resin was bulk pretreated with de-ionized (DI) water, $1 \underline{\mathrm{M}} \mathrm{NaOH}$, and $0.5 \underline{\mathrm{M}} \mathrm{HNO}_{3}$ to cycle between $\mathrm{Na}^{+}$and $\mathrm{H}^{+}$-forms.

The batch testing samples required 72 simulants to be prepared with varying amounts of $\mathrm{Cs}, \mathrm{Na}, \mathrm{K}$, $\mathrm{OH}$, and $\mathrm{NO}_{3}$. The $\mathrm{Na}^{+}$form resin was contacted with each simulant for $72 \mathrm{hr}$ at varying temperatures $\left(25,35,50^{\circ} \mathrm{C}\right)$ with mixing and then sampled to determine the Cs loading on the resin.

For column testing, resin was placed in columns and further pretreated with another acid/base cycle prior to simulant loading. For batch resin testing, the resin was loaded after the bulk pretreatment. Dry resin density was determined by drying duplicate samples under vacuum at $50^{\circ} \mathrm{C}$ to constant mass.

Four columns of SRF resin were loaded with a simple simulant containing $\mathrm{Cs}, \mathrm{Na}, \mathrm{K}, \mathrm{Al}, \mathrm{OH}$, and $\mathrm{NO}_{3}$, partially eluted with 3 bed volumes (BV) $0.5 \underline{\mathrm{M}} \mathrm{HNO}_{3}$ and then eluted with $25+\mathrm{BV}$ of $0.25 \underline{\mathrm{M}}$ $\mathrm{HNO}_{3}$ solution. These columns were cycled through a series of five loading and elution cycles.

All test conditions delineated by the test plan and test exceptions were met. A summary of test conditions is provided in Table S.4.

\footnotetext{
${ }^{1}$ System for managing the delivery of PNNL policies, requirements, and procedures.
} 
Table S.4. R\&T Test Condition Summary

List R\&T Test Conditions

1) Ion Exchange Loading Kinetics Tests

(a) Small-column ion exchange loading tests were performed using near prototypic flow conditions with feed recycle until equilibrium loading was achieved in order to evaluate cesium uptake kinetics.

(b) The results from these tests will be used to assess the impact of linear load velocity and the impact of high free hydroxide on resin degradation during extended solution flow using elevated temperatures. Preliminary results of testing will be transmitted to the WTP Project lead.
Were Test Conditions Followed?

(a) A series of column loading and elution cycles were completed as detailed in Table 3.4. The composition of the simulant used is shown in Table 3.1. The ion exchange columns were loaded with simulant feed solution at temperatures between $25 \pm 2^{\circ} \mathrm{C}$ and $60 \pm 2^{\circ} \mathrm{C}$. The solution was processed at various flow velocities as shown in Table 3.4 for the $10 \mathrm{~h}$ to 30 days of loading. Following loading, the feed solution was displaced with $7.5 \mathrm{BV}$ of $0.1 \mathrm{M} \mathrm{NaOH}$, rinsed with 7.5 BV of DI water, and the resin was neutralized with $3 \mathrm{BV}$ of $0.5 \mathrm{M} \mathrm{HNO}_{3}$ at $3 \mathrm{BV} / \mathrm{h}$ as is outlined in Table 3.3.

(b) The results from these tests were used to assess the impact of linear load velocity and the impact of high free hydroxide on resin degradation during extended solution flow using elevated temperatures as discussed in Sections 4.1 and 4.2. Preliminary results of the testing were transmitted to the WTP Project lead.
2) Ion Exchange Batch Loading Tests

(a) Several small $(<1 \mathrm{~mL})$ batches of conditioned SRF resin were each contacted with supernate simulants containing various $\mathrm{Na}, \mathrm{Cs}, \mathrm{K}$, and $\mathrm{OH}$ ion concentrations. The balance of the simulant was nitrate ion. Approximately $0.1 \mathrm{~g}$ resin was contacted with $\sim 25 \mathrm{~mL}$ of simulant (volumetric phase ratio of 150:1) for $72 \mathrm{hr}$ to ensure equilibrium had been reached. Sub-sets of samples were mixed at approximately $25^{\circ} \mathrm{C}$, $35^{\circ} \mathrm{C}$ and $50^{\circ} \mathrm{C}$.

(b) Data from this testing was analyzed to determine the impact of $\mathrm{Na}, \mathrm{OH}$, and $\mathrm{K}$ levels on Cs loading. (a) Approximately $0.1 \mathrm{~g}$ of dry resin was added to $\sim 25 \mathrm{~mL}$ of each of the 72 simulants and mixed at the designated temperature of 25,35 , or $50^{\circ} \mathrm{C}$ for $72 \mathrm{hr}$ and then sampled. Samples were analyzed for Cs concentration to determine Cs loading under these conditions.

(b) The data from this testing was analyzed and the impact of these variables is reported in Section 4.3.

\section{Simulant Use}

The small-column kinetics loading testing task was performed using a single nonradioactive aqueous simulant solution for $\mathrm{Cs}$ loading of the SRF resin. The nominal $\mathrm{Na}$, Cs, free $\mathrm{OH}$, and $\mathrm{Al}$ concentrations were selected to be $5 \underline{\mathrm{M}}, 4.5 \mathrm{E}-05 \underline{\mathrm{M}}, 1.55 \underline{\mathrm{M}}$, and $0.115 \underline{\mathrm{M}}$, respectively. The anion used to obtain these concentrations was nitrate. This simulant was not selected to represent any particular Hanford tank waste type. 
The batch loading tests were performed with a variety of 72 different simulants with varying amounts of $\mathrm{Na}, \mathrm{K}, \mathrm{Cs}, \mathrm{OH}$, and $\mathrm{NO}_{3}$. Na ranged from 0.1 to $5 \underline{\mathrm{M}}$ and the Cs ranged from 5.0E-06 to 5.0E-03 $\underline{\mathrm{M}}$. $\mathrm{K}$ was either 0.005 or $0.05 \underline{\mathrm{M}}$ and free $\mathrm{OH}$ was either 0.1 or $1 \underline{\mathrm{M}}$. The anion used to obtain these concentrations was nitrate. The simulants were not selected to represent any particular Hanford tank waste type but to assess the ion effect over varying concentration ranges.

\section{Discrepancies and Follow-on Tests}

The extended run tests at 55 and $60^{\circ} \mathrm{C}$ that were intended to run for $720 \mathrm{hr}$ were aborted after $\sim 336 \mathrm{hr}$ due to column plugging. The extended run test at $50^{\circ} \mathrm{C}$ intended to run for $720 \mathrm{hr}$ was aborted after $\sim 600 \mathrm{hr}$ due to column plugging. When tested, the resin was a hard clump that was difficult to break up, and therefore prevented solution from flowing through it. Two columns had to be opened and the resin mass broken up before they could be eluted. 



\section{Acknowledgments}

The authors would like to thank the Southwest Research Institute (Daniel Ramirez and other staff, San Antonio, Texas) for analytical support. The authors also would like to thank David Sherwood of the Hanford Tank Waste Treatment and Immobilization Plant project for his support. The authors are grateful for the assistance of Pacific Northwest National Laboratory staff members Mike Parker for editorial and document design support and Garrett Brown for technical review. 



\section{Acronyms and Abbreviations}

ASTM

BNI

BV

CXP

DIW

DOE

FFPM

GGRF

HDI

HLW

IC

ICP

LAW

MS

NA

OES

ORP

PNNL

PTF

PTFE

PVDF

QA

$\mathrm{R} \& \mathrm{D}$

RF

$\mathrm{RPP}$

$\mathrm{R} \& \mathrm{~T}$

RV

SRF

SwRI

TIC

TOC

TRU

WSRC

WTP

WTPSP
American Society for Testing and Materials

Bechtel National, Inc.

bed volumes

cesium ion exchange process

de-ionized water

U.S. Department of Energy

perfluorinated elastomer

ground gel resorcinol-formaldehyde

How Do I

high-level waste

ion chromatography

inductively coupled plasma

low activity waste

mass spectroscopy

not applicable

optical emission spectroscopy

Office of River Protection

Pacific Northwest National Laboratory

Pretreatment Facility

polytetrafluoroethylene

polyvinylidene fluoride

quality assurance

research and development

resorcinol-formaldehyde

River Protection Project

research and technology

resin volume

spherical resorcinol-formaldehyde

Southwest Research Institute

total inorganic carbon

total organic carbon

transuranic

Westinghouse Savannah River Company

Hanford Tank Waste Treatment and Immobilization Plant

Waste Treatment Plant Support Project 



\section{Contents}

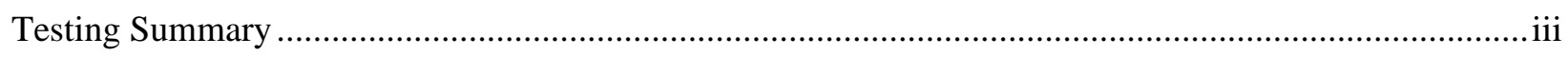

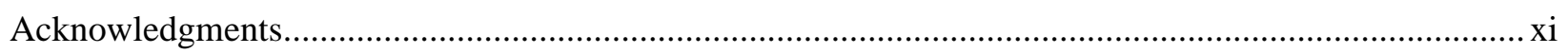

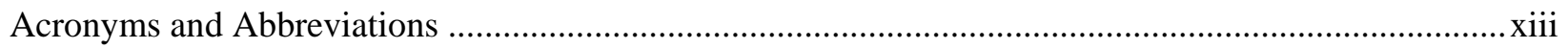

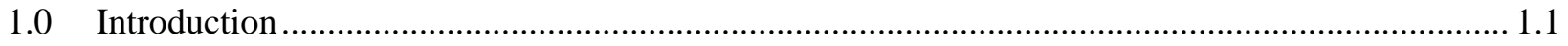

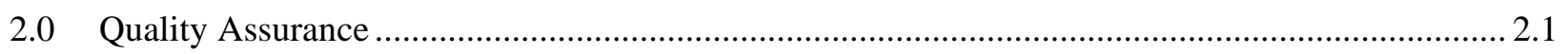

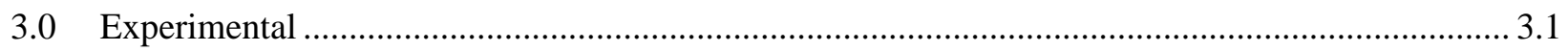

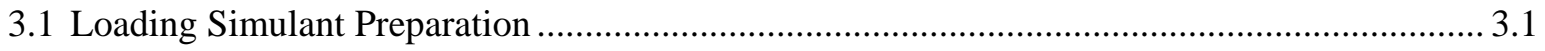

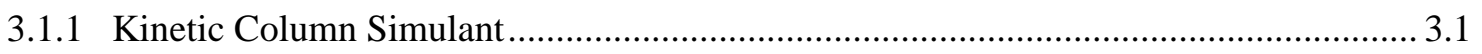

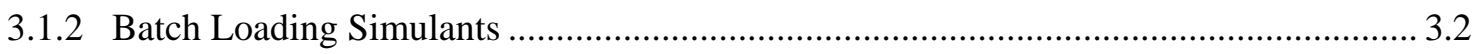

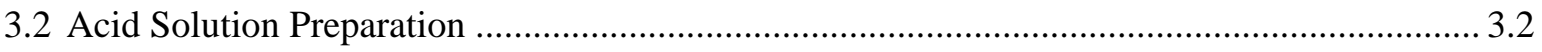

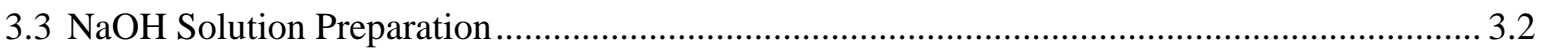

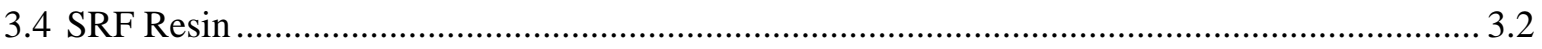

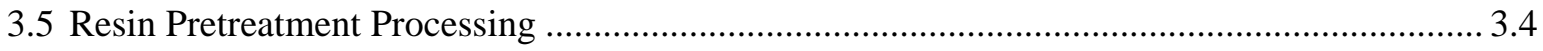

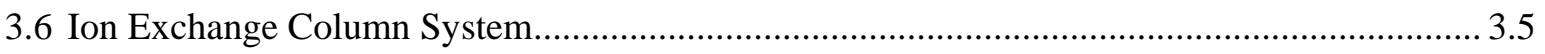

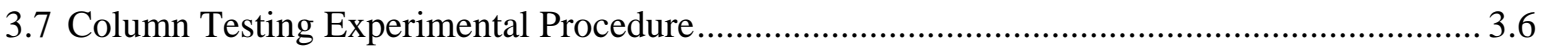

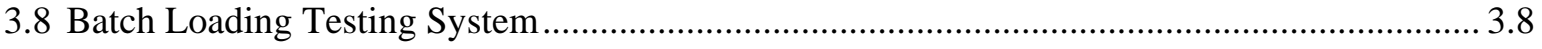

3.9 Batch Testing Experimental Procedure ….................................................................... 3.8

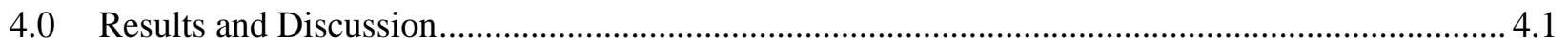

4.1 Impacts of Linear Load Velocity and Temperature on Resin Cs Loading Kinetics .................. 4.1

4.2 Impacts of Extended Elevated Temperature on Resin Loading.............................................. 4.5

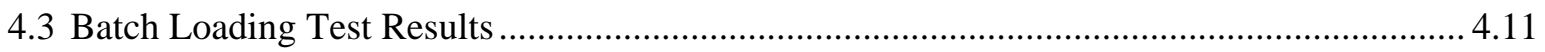

4.3.1 Na Effect on Resin Cs Loading ............................................................................ 4.12

4.3.2 K Effect on Resin Cs Loading................................................................................. 4.13

4.3.3 OH Effect on Resin Cs Loading Capacity................................................................. 4.14

4.3.4 Temperature Effect on Resin Cs Loading Capacity .................................................. 4.17

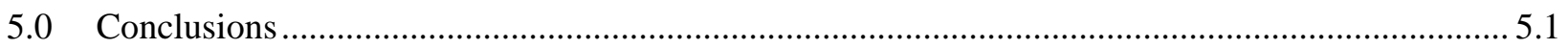

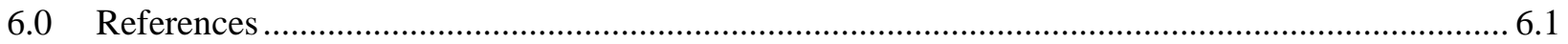

Appendix A - Column Sampling Information................................................................................. A.1

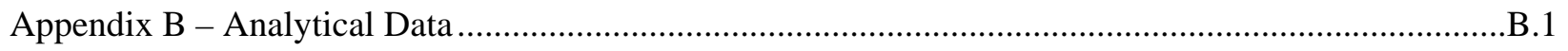




\section{Figures}

3.1. Representative SRF Resin Sample for Column Testing Showing Darkened Resin Beads .............. 3.3

3.2. A Visible Light Microscopy Image of SRF Resin ..................................................................... 3.3

3.3. Differential Column Ion Exchange Kinetics Schematic ............................................................. 3.6

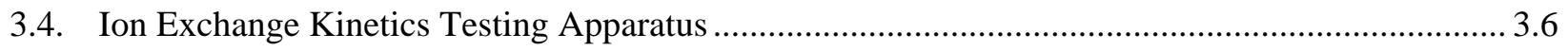

3.5. Batch Cs Loading Temperature Controlled Orbital Shaker Table ................................................ 3.14

4.1. Velocity Impact on Kinetics of Column A $\left(45^{\circ} \mathrm{C}\right)$ Cs Loading ...................................................... 4.2

4.2. Velocity Impact on Kinetics of Column B $\left(40^{\circ} \mathrm{C}\right)$ Cs Loading ...................................................... 4.2

4.3. Velocity Impact on Kinetics of Column $\mathrm{C}\left(30^{\circ} \mathrm{C}\right) \mathrm{Cs}$ Loading ....................................................... 4.3

4.4. Velocity Impact on Kinetics of Column D $\left(25^{\circ} \mathrm{C}\right)$ Cs Loading .................................................... 4.3

4.5. Temperature Effect on Cs Loading Kinetics of Test 1................................................................ 4.4

4.6. Temperature Effect on Cs Loading Kinetics of Test 2 ................................................................ 4.4

4.7. Temperature Effect on Kinetics of Test $3(4 \mathrm{~cm} / \mathrm{min})$.............................................................. 4.5

4.8. Resin Total Cs Loading After Extended Flow Testing ................................................................... 4.6

4.9. Resin Cs Loading During Extended Flow Testing..................................................................... 4.7

4.10. Feed Displacement Solution Compared Before and After Running Through the Column.............. 4.7

4.11. First and Fifth Resin Loading Cycles Compared at $45^{\circ} \mathrm{C}$ with Long Loading Cycle at $60^{\circ} \mathrm{C} . . . . . . . .4 .8$

4.12. First and Fifth Resin Loading Cycles Compared at $40^{\circ} \mathrm{C}$ with Long Loading Cycle at $55^{\circ} \mathrm{C} . . . . . . . .4 .9$

4.13. First and Fifth Resin Loading Cycles Compared at $30^{\circ} \mathrm{C}$ with Long Loading Cycle at $50^{\circ} \mathrm{C}$........ 4.9

4.14. First and Fifth Resin Loading Cycles Compared at $25^{\circ} \mathrm{C}$ with Long Loading Cycle at $45^{\circ} \mathrm{C} \ldots . . . .4 .10$

4.15. Microscopic Comparison of Resin from All Tests.................................................................. 4.11

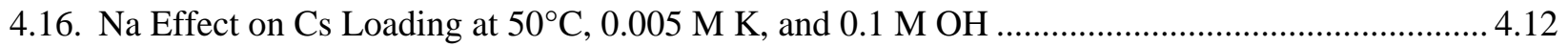

4.17. Na Effect on Cs Loading at $25^{\circ} \mathrm{C}, 0.005 \mathrm{M} \mathrm{K}$, and $0.1 \mathrm{M} \mathrm{OH}$...................................................13

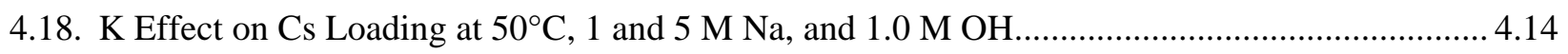

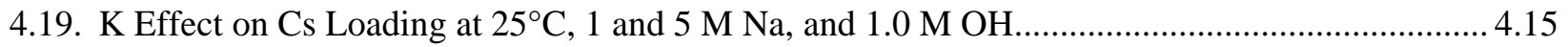

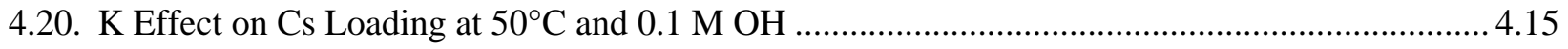

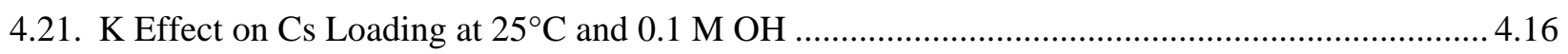

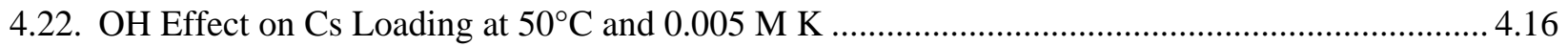

4.23. OH Effect on Cs Loading at $25^{\circ} \mathrm{C}$ and $0.005 \mathrm{M} \mathrm{K}$.................................................................. 4.17

4.24. Temperature Effect of $\mathrm{Na}$ on Cs Loading at $0.1 \mathrm{M} \mathrm{OH}$ and $0.005 \mathrm{M} \mathrm{K....................................} 4.18$

4.25. Temperature Effect of $\mathrm{K}$ on Cs Loading at $0.1 \mathrm{M} \mathrm{OH}$ and $0.1 \mathrm{M} \mathrm{Na}$........................................ 4.19

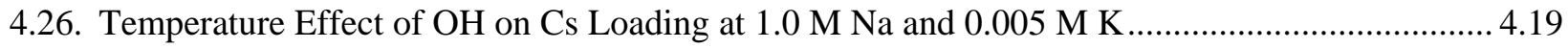

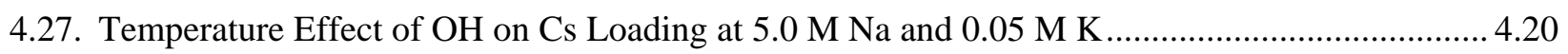




\section{Tables}

3.1. Column Testing Simulant Solution for Cesium Ion Exchange Loading ........................................ 3.1

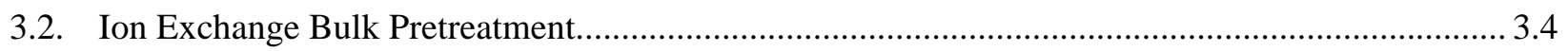

3.3. Ion Exchange Pretreatment and Process Steps in Column ........................................................... 3.5

3.4. Ion Exchange Temperature Impact Experimental Design ........................................................... 3.7

3.5. Sodium Impact Experimental Design ....................................................................................... 3.9

4.1. Average Particle Size of Resin Both Before and After Use ........................................................... 4.10 



\subsection{Introduction}

The U.S. Department of Energy (DOE) Hanford Site contains more than 53 million gallons of legacy waste generated as a byproduct of plutonium production and reprocessing operations. The wastes are a complex mixture composed mostly of $\mathrm{NaNO}_{3}, \mathrm{NaNO}_{2}, \mathrm{NaOH}, \mathrm{NaAlO}_{2}, \mathrm{Na}_{3} \mathrm{PO}_{4}$, and $\mathrm{Na}_{2} \mathrm{SO}_{4}$, with a number of minor and trace metals, organics, and radionuclides stored in underground waste tanks. The DOE's Office of River Protection (ORP) has contracted Bechtel National Incorporated (BNI) to build a pretreatment facility (PTF), the River Protection Project-Waste Treatment Plant (RPP-WTP), that will separate long-lived transuranics (TRU) and highly radioactive components (specifically ${ }^{137} \mathrm{Cs}$ and, in selected cases, ${ }^{90} \mathrm{Sr}$ ) from the bulk (nonradioactive) constituents and immobilize the wastes by vitrification. The plant is designed to produce two waste streams: a high-volume low-activity waste (LAW) and a low-volume high-activity waste (HLW).

Ion exchange using the spherical resorcinol-formaldehyde (SRF) resin has been selected by the WTP project and approved by DOE-ORP for use in the PTF of the RPP-WTP. The SRF resin is an engineered spherical form of the older ground gel resorcinol-formaldehyde (GGRF) resin, also termed resorcinol-formaldehyde (RF), which was developed and evaluated at the Westinghouse Savannah River Company (WSRC) in the 1980s (Ebra and Wallace 1983; Bibler et al. 1989). Numerous studies at Hanford and other DOE sites have shown the GGRF and SRF resins to be effective for removing ${ }^{137} \mathrm{Cs}$ from a wide variety of simulated and actual tank waste supernatants and for achieving less than the proposed spent waste classification criteria of $<100 \mathrm{nCi}$ TRU and $<60 \mu \mathrm{Ci}{ }^{137} \mathrm{Cs}$ per gram of spent resin (Adamson et al. 2006; Blanchard et al. 2008; Burgeson et al. 2004; Duignan and Nash 2009; Fiskum et al. 2006a; Fiskum et al. 2006b; Fiskum et al. 2006c; Fiskum et al. 2007; Hassan and Adu-Wusu 2003; King et al. 2004; Kurath et al. 1994; Nash et al. 2006).

Prior work has focused primarily on loading behavior for $5 \underline{\mathrm{M}}$ Na solutions at $25^{\circ} \mathrm{C}$ (Hassan et al. 2004; King et al. 2004; Peterson et al. 2006; Fiskum et al. 2006a). Recent proposed changes to the process baseline in the PTF indicate that both a broader range of sodium molarities $(0.1$ to $8 \underline{\mathrm{M}})$ and higher temperatures may be required to alleviate post-filtration precipitation issues. The objective of this report is to summarize the results of the resin's Cs loading under lower Na concentrations and higher temperatures as well as the resin's Cs loading kinetics and degradation at $5 \underline{\mathrm{M}} \mathrm{Na}$ under higher temperatures. Previous work focused on testing the higher Na concentrations (5 to $8 \underline{\mathrm{M}}$ ) as reported by Russell (2012).

Section 1.0 provides a brief historical background for HLW, Cs ion exchange, and the test design. Section 2.0 details the basis of the Pacific Northwest National Laboratory (PNNL) Quality Assurance (QA) Program as applied to the RPP-WTP quality requirements. Section 3.0 describes the test design, solution and resin preparations, equipment, process steps, and chemical analyses. Section 4.0 provides a summary of the experimental data and includes a discussion of the results of the Cs ion exchange kinetics testing and the Cs loading under various conditions. Section 5.0 provides a list of conclusions obtained from this experimental work. Section 6.0 provides a list of references cited in this report. Appendix A and Appendix B list experimental conditions and analytical data, respectively. 



\subsection{Quality Assurance}

The PNNL QA Program is based on the requirements defined in DOE Order 414.1D, Quality Assurance, and Title10 of the Code of Federal Regulations (CFR) Part 830, Energy/Nuclear Safety Management, and Subpart A, Quality Assurance Requirements (a.k.a. the Quality Rule). PNNL has chosen to implement the following consensus standards in a graded approach:

- ASME NQA-1-2000, Quality Assurance Requirements for Nuclear Facility Applications, Part 1, Requirements for Quality Assurance Programs for Nuclear Facilities.

- ASME NQA-1-2000, Part II, Subpart 2.7, Quality Assurance Requirements for Computer Software for Nuclear Facility Applications.

- ASME NQA-1-2000, Part IV, Subpart 4.2, Graded Approach Application of Quality Assurance Requirements for Research and Development.

The procedures necessary to implement the requirements are documented through PNNL's "How Do I...?” (HDI) system. ${ }^{1}$

The Waste Treatment Plant Support Project (WTPSP) implements an NQA-1-2000 QA Program, graded on the approach presented in NQA-1-2000, Part IV, Subpart 4.2. The WTPSP QA Manual (QA-WTPSP-0002) describes the technology life cycle stages under the WTPSP QA Plan (QA-WTPSP-0001). The technology life cycle includes the progression of technology development, commercialization, and retirement in process phases of basic and applied research and development $(R \& D)$, engineering and production and operation until process completion. The life cycle is characterized by flexible and informal QA activities in basic research, which becomes more structured and formalized through the applied R\&D stages.

The work described in this report has been completed under the QA technology level of Applied Research. WTPSP addresses internal verification and validation activities by conducting an Independent Technical Review of the final data report in accordance with the WTPSP procedure QA-WTPSP-601, Document Preparation and Change. This independent review verifies that the reported results are traceable, that inferences and conclusions are soundly based, and that the reported work satisfies the test plan objectives.

\footnotetext{
${ }^{1}$ System for managing delivery of PNNL policies, requirements, and procedures.
} 



\subsection{Experimental}

This section summarizes the loading simulant preparation, acid solution preparation, $\mathrm{NaOH}$ solution preparation, SRF resin, resin pretreatment processing, ion exchange column system, column testing experimental procedure, batch loading testing system, and batch testing experimental procedure. Detailed laboratory test instructions were provided by internal documentation. ${ }^{1,2,3}$ Data and observations were recorded on photocopied datasheets and the printed test instructions. Experimental conditions and analytical data are provided in Appendix A and Appendix B, respectively.

\subsection{Loading Simulant Preparation}

\subsubsection{Kinetic Column Simulant}

The small-column Cs loading kinetics testing task was performed using one nonradioactive aqueous simulant solution for loading Cs onto the SRF resin. This loading simulant composition is shown in Table 3.1. The nominal Na, Cs, free $\mathrm{OH}$, and $\mathrm{K}$ concentrations were selected to be $5 \underline{\mathrm{M}}, 4.51 \mathrm{E}-05 \underline{\mathrm{M}}$, $1.2 \underline{\mathrm{M}}$, and $0.030 \underline{\mathrm{M}}$, respectively. This Cs loading simulant was not selected to represent any particular Hanford tank waste type.

Approximately $6 \mathrm{~L}$ of this Cs loading simulant solution was prepared. All chemicals were added to the bottle based on weight $( \pm 0.1 \mathrm{~g})$ and were within 0.1 percent of the target. The density of the Cs loading simulant was measured to be $1.23 \mathrm{~g} / \mathrm{mL}$.

Table 3.1. Column Testing Simulant Solution for Cesium Ion Exchange Loading

\begin{tabular}{llc}
\hline \multicolumn{1}{c}{ Compound } & \multicolumn{1}{c}{ Formula } & Concentration (M) \\
\hline Potassium nitrate & $\mathrm{KNO}_{3}$ & 0.030 \\
Aluminum nitrate & $\mathrm{Al}\left(\mathrm{NO}_{3}\right)_{3}-9 \mathrm{H}_{2} \mathrm{O}$ & 0.150 \\
Sodium phosphate & $\mathrm{Na}_{3} \mathrm{PO}_{4}-12 \mathrm{H}_{2} \mathrm{O}$ & 0.013 \\
Sodium nitrate & $\mathrm{NaNO}_{3}$ & 1.56 \\
Sodium sulfate & $\mathrm{Na}_{2} \mathrm{SO}_{4}$ & 0.011 \\
Sodium hydroxide & $\mathrm{NaOH}$ & 1.20 \\
Sodium carbonate & $\mathrm{Na}_{2} \mathrm{CO}_{3}$ & 0.663 \\
Sodium oxalate & $\mathrm{Na}_{2} \mathrm{C}_{2} \mathrm{O}_{4}$ & 0.017 \\
Sodium nitrite & $\mathrm{NaNO}_{2}$ & 0.831 \\
Cesium nitrate & $\mathrm{CsNO}_{3}$ & $4.51 \mathrm{E}-5$ \\
\hline
\end{tabular}

\footnotetext{
${ }^{1}$ Russell RL. 2012. Simulant Preparation for Ion Exchange Batch Testing. TI-WTPSP-064, Rev. 0, Pacific Northwest National Laboratory, Richland, Washington.

${ }^{2}$ Russell RL. 2012. Resin Batch Contact Loading Tests. TI-WTPSP-065, Rev 0, Pacific Northwest National Laboratory, Richland, Washington.

${ }^{3}$ Russell RL. 2012. FY12 Small Column SRF Ion Exchange Kinetics Testing. TI-WTPSP-077, Rev 0, Pacific Northwest National Laboratory, Richland, Washington.
} 


\subsubsection{Batch Loading Simulants}

The batch Cs loading testing task was performed using 72 nonradioactive aqueous simulant solutions for Cs loading onto the SRF resin. These Cs loading simulant compositions are shown in Table 3.1 and were chosen to provide a wide range of each ion. The nominal Na concentration was selected to be between 0.1 and $5 \underline{\mathrm{M}}$, the nominal Cs concentration was selected to be between 5.0E-06 and 5.0E-03 $\underline{\mathrm{M}}$, the free $\mathrm{OH}$ concentration was selected to be either 0.1 or $1.0 \mathrm{M}$, and the K concentration was selected to be either 0.005 or $0.05 \underline{\mathrm{M}}$. The anion used to obtain these concentrations was nitrate. These simulants did not contain $\mathrm{Al}$ as opposed to the column test simulant. These Cs loading simulants were not selected to represent any particular Hanford tank waste type.

Approximately $500 \mathrm{~mL}$ of each Cs loading simulant solution was prepared. All chemicals were added to the bottle based on weight $( \pm 0.1 \mathrm{~g})$ and were within 0.1 percent of the target except Cs which was added based on weight but to $\pm 0.0001 \mathrm{~g}$. The density of the Cs loading simulants were measured and ranged from 1.00 to $1.26 \mathrm{~g} / \mathrm{mL}$.

\subsection{Acid Solution Preparation}

Elution $\left(0.25 \underline{\mathrm{M} \mathrm{HNO}_{3}}\right)$ and acid conversion solutions $\left(0.50 \underline{\mathrm{M}} \mathrm{HNO}_{3}\right)$ were prepared by volumetric dilution of reagent-grade concentrated $\mathrm{HNO}_{3}$ with de-ionized (DI) water in a volumetric flask.

\subsection{NaOH Solution Preparation}

$\mathrm{NaOH}$ solutions for SRF resin pretreatment $(1.0 \underline{\mathrm{M}})$, regeneration $(0.50 \underline{\mathrm{M}})$, and feed displacement $(0.10 \underline{\mathrm{M}})$ were prepared by weighing $( \pm 0.1 \mathrm{~g}) 50$ percent $\mathrm{NaOH}$ solution into volumetric flasks and diluting to volume using DI water.

\subsection{SRF Resin}

The SRF resin used in these tests was from existing stock (Microbeads, Skedsmokorset, Norway, Lot Number 5E-370/641) that had been stored at PNNL for more than four years. The resin had been stored in the $\mathrm{H}^{+}$-form in water under $\mathrm{N}_{2}$ in sealed 2-L plastic bottles. A small (3 mm) layer of the resin was dark brown, indicating possible oxidative degradation, in contrast to the orange color of the remaining bulk. Upon opening the container, the top layer of resin was removed by vacuum sluicing and disposed of without use. The remaining resin was thoroughly mixed, and a representative sample was removed for use in the experiments using a coring technique consistent with the American Society for Testing and Materials (ASTM) Method 2687, Standard Practice for Sampling Particulate Ion-Exchange Materials (ASTM 2001). Even after vacuum sluicing of the top, darker brown layer and mixing the remaining material, a small fraction ( $<1$ percent) of the sampled resin still exhibited the darker brown color as shown in Figure 3.1. The small fraction was deemed inconsequential and no further separation was attempted. Figure 3.2 displays an example visible light microscopy image of the SRF resin. 


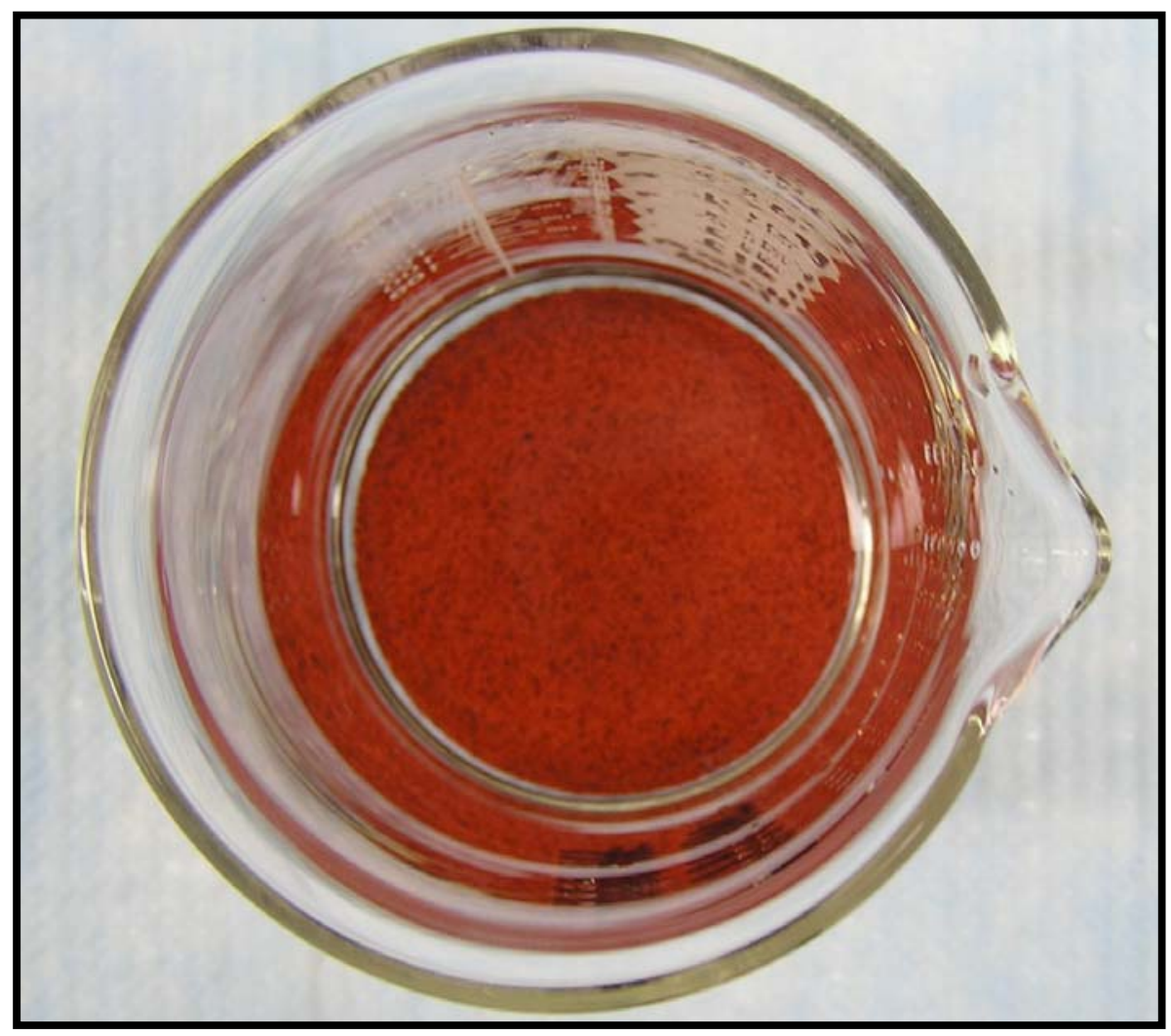

Figure 3.1. Representative SRF Resin Sample for Column Testing Showing Darkened Resin Beads

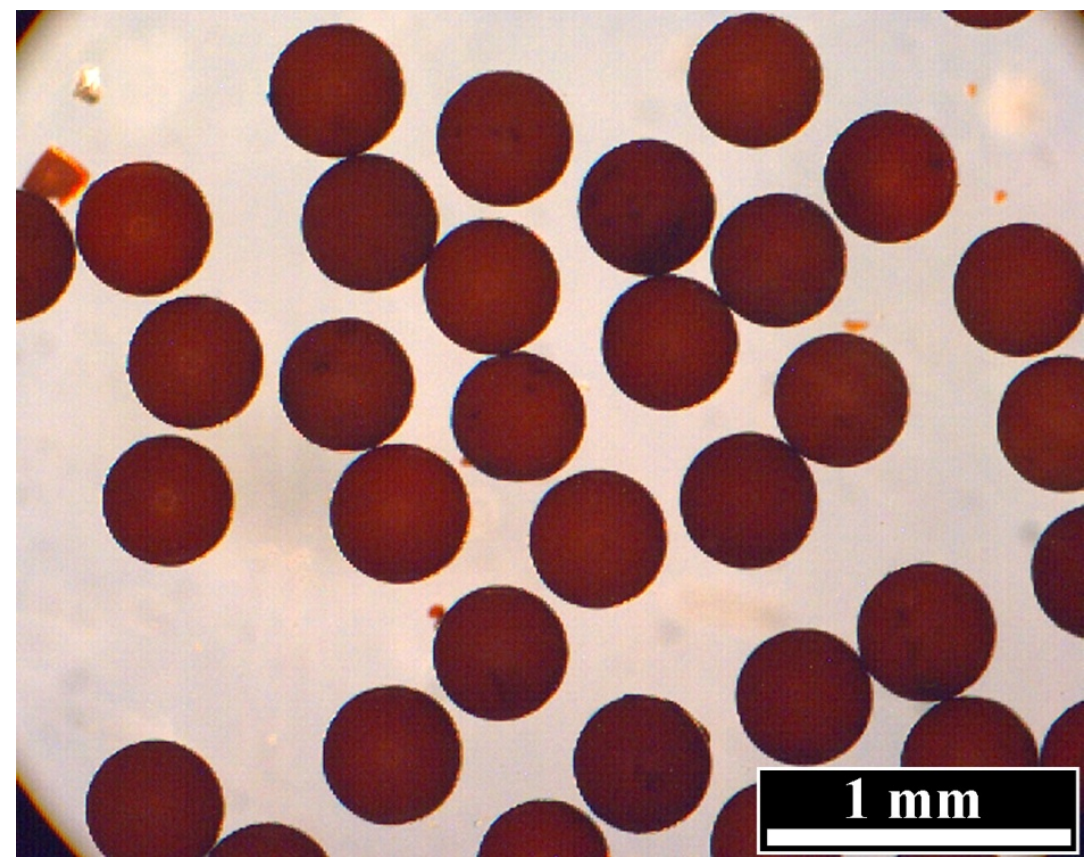

Figure 3.2. A Visible Light Microscopy Image of SRF Resin 


\subsection{Resin Pretreatment Processing}

The overall resin bulk pretreatment and column pretreatment steps are shown in Table 3.2 and Table 3.3, respectively, and are consistent with previous testing ${ }^{(1)}$ (Arm and Blanchard 2004; Fiskum et al. 2006b; Fiskum et al. 2006c). The bulk pretreatment processes used a full resin expansion/contraction cycle in an open beaker format as described in Fiskum et al. 2007, which allows for full expansion of the resin without it being constrained inside the ion exchange column and for the batch testing resin to be pretreated.

Table 3.2. Ion Exchange Bulk Pretreatment

\begin{tabular}{|c|c|c|c|c|c|c|}
\hline & Process/Pretreatment Step & Solution & Volume & Time & Mixing & Flowrate \\
\hline \multicolumn{7}{|c|}{ Batch Bulk Pretreatment } \\
\hline & Water Rinse & DI Water & $5 \mathrm{RV}^{(\mathrm{a})}$ & $0.5 \mathrm{hr}$ & Swirl $^{(\mathrm{b})}$ & $\mathrm{NA}^{(\mathrm{c})}$ \\
\hline & Resin Expansion & $1 \underline{\mathrm{M}} \mathrm{NaOH}$ & $5 \mathrm{RV}$ & $16 \mathrm{hr}$ & Soak & NA \\
\hline & Water Rinse $-1^{\text {st }}$ & DI Water & $4.2 \mathrm{RV}$ & $0.5 \mathrm{hr}$ & Swirl & NA \\
\hline & Water Rinse $-2^{\text {nd }}$ & DI Water & $4.2 \mathrm{RV}$ & $0.5 \mathrm{hr}$ & Swirl & NA \\
\hline & Water Rinse $-3^{\text {rd }}$ & DI Water & $4.2 \mathrm{RV}$ & $0.5 \mathrm{hr}$ & Swirl & NA \\
\hline & Resin Conversion & $0.5 \underline{\mathrm{M}} \mathrm{HNO}_{3}$ & $7.5 \mathrm{RV}$ & $2.5 \mathrm{hr}$ & Swirl & NA \\
\hline & Water Rinse $-4^{\text {th }}$ & DI Water & $7.5 \mathrm{RV}$ & $2 \mathrm{~min}$ & Swirl & NA \\
\hline & Resin Expansion & $1 \underline{\mathrm{M}} \mathrm{NaOH}$ & 7.5 RV & $1.33 \mathrm{hr}$ & Swirl & NA \\
\hline & Water Rinse $-5^{\text {th }}$ & DI Water & $7.5 \mathrm{RV}$ & $2 \mathrm{~min}$ & Swirl & NA \\
\hline \multicolumn{7}{|c|}{$\begin{array}{l}\text { Resin volume (RV). } \\
\text { Gently swirling by hand every } 10 \text { min. } \\
\text { Not applicable (NA). }\end{array}$} \\
\hline
\end{tabular}

Following bulk pretreatment, some of the $\mathrm{Na}^{+}$-form resin was slurry-transferred into the ion exchange column, rinsed with DI water, and converted into the $\mathrm{H}^{+}$-form with up-flow $0.5 \underline{\mathrm{M}} \mathrm{HNO}_{3}$. The resin was then converted back into the $\mathrm{Na}^{+}$-form with up-flow $0.5 \underline{\mathrm{M} \mathrm{NaOH}}$.

Six $10 \mathrm{~mL}$ sub-samples of the resin, three in the $\mathrm{H}^{+}$-form and three that had been converted to the $\mathrm{Na}^{+}$-form, were dried to a constant mass at $50^{\circ} \mathrm{C}$ in a vacuum oven. Constant mass was defined as $<0.1$ percent mass variation over two consecutive measurements taken at an interval of at least $7 \mathrm{hr}$. The average density of the resin was calculated to be $0.454 \mathrm{~g} / \mathrm{mL}$ (mass of dried $\mathrm{H}^{+}$-form resin per $\mathrm{mL}$ of settled $\mathrm{H}^{+}$-form resin under water in a $10 \mathrm{~mL}$ graduated cylinder), consistent with values reported previously (Fiskum et al. 2006b; Fiskum et al. 2006c).

\footnotetext{
${ }^{1}$ Nash CA and CE Duffey. August 17, 2004. Hanford RPP-WTP Alternate Resin Program -Protocol P1-RF: Spherical Resin Sampling from Containers, Resin Pretreatment, F-Factor, and Resin Loading to Column, WTP 097893, Savannah River National Laboratory.
} 
Table 3.3. Ion Exchange Pretreatment and Process Steps in Column

\begin{tabular}{|c|c|c|c|c|c|}
\hline Process/Pretreatment Step & Solution & Volume & Time & Mixing & Flowrate \\
\hline \multicolumn{6}{|c|}{ Column Pretreatment } \\
\hline Water Rinse & DI Water & $7.5 \mathrm{BV}^{(\mathrm{a})}$ & $2.5 \mathrm{hr}$ & Flow & $3 \mathrm{BV} / \mathrm{h}$ \\
\hline Acid Rinse & $0.5 \underline{\mathrm{M}} \mathrm{HNO}_{3}$ & $8 \mathrm{BV}$ & $2.7 \mathrm{hr}$ & Flow & $3 \mathrm{BV} / \mathrm{h}$ \\
\hline Water Rinse & DI Water & $3 \mathrm{BV}$ & $1 \mathrm{hr}$ & Flow & $3 \mathrm{BV} / \mathrm{h}$ \\
\hline Feed Prep & $0.5 \underline{\mathrm{M} \mathrm{NaOH}}$ & $6 \mathrm{BV}$ & $2 \mathrm{hr}$ & Flow & $3 \mathrm{BV} / \mathrm{h}$ \\
\hline \multicolumn{6}{|c|}{ Column Loading/Eluting } \\
\hline Simulant & Simulant & variable & $10 \mathrm{hr}$ & Flow & variable \\
\hline Feed Displaced & $0.1 \underline{\mathrm{M}} \mathrm{NaOH}$ & $7.5 \mathrm{BV}$ & $2.5 \mathrm{hr}$ & Flow & $3 \mathrm{BV} / \mathrm{h}$ \\
\hline Water Rinse & DI Water & $7.5 \mathrm{BV}$ & $2.5 \mathrm{hr}$ & Flow & $3 \mathrm{BV} / \mathrm{h}$ \\
\hline Neutralization & $0.5 \underline{\mathrm{M}} \mathrm{HNO}_{3}$ & $3 \mathrm{BV}$ & $1 \mathrm{hr}$ & Flow & $3 \mathrm{BV} / \mathrm{h}$ \\
\hline Acid Elution & $0.25 \underline{\mathrm{M}} \mathrm{HNO}_{3}$ & $25 \mathrm{BV}$ & $10 \mathrm{hr}$ & Flow & $2.8 \mathrm{BV} / \mathrm{h}$ \\
\hline Water Rinse & DI Water & $3 \mathrm{BV}$ & $1 \mathrm{hr}$ & Flow & $3 \mathrm{BV} / \mathrm{h}$ \\
\hline Regeneration & $0.5 \underline{\mathrm{M} ~ N a O H}$ & $6 \mathrm{BV}$ & $2 \mathrm{hr}$ & Flow & $3 \mathrm{BV} / \mathrm{h}$ \\
\hline
\end{tabular}

\subsection{Ion Exchange Column System}

The kinetics experimental setup was based on a differential column concept described in detail in Duffey et al. (2003). This concept uses a thin resin bed exposed to a feed solution with nearly uniform uptake throughout the bed. In essence, this setup is designed to determine resin adsorption properties of a differential cross-sectional area of an ion exchange column. Implementation requires a controlled flow of liquid through the resin bed, a controlled temperature throughout the system, and continuous homogenization of the liquid phase. A schematic of the kinetics experimental setup is shown in Figure 3.3 and the actual system is shown in Figure 3.4.

Resin test samples were placed into the jacketed column. The resin was held in place between 200 mesh stainless steel screens. The simulant was fed through the column in an up-flow manner to minimize the amount of air initially in the system. The entire system remained closed with the exception of a small vent/sampling port in the simulant feed bottle. The target resin bed path length and diameter were 10.1 and $15.0 \mathrm{~mm}$ respectively, giving a target resin volume of $1.8 \mathrm{~mL}$, which is similar to those reported by Duffey et al. (2003).

The simulant feed was held within a capped $125 \mathrm{~mL}$ polyethylene bottle and was continually stirred with a 1-in. polytetrafluoroethylene (PTFE) stir bar. Approximately $3 \mathrm{~mL}$ samples were taken from the simulant feed bottle at $0,6,12,18,24,36,48,60,80,120,180,240$, and 600 minutes using a $10 \mathrm{~mL}$ plastic syringe with a 4-in. \#18 stainless steel needle through the sampling port. The simulant feed bottle was wrapped in a heat jacket that was temperature controlled using a calibrated Type K thermocouple and a Digi-Sense temperature controller (Thermo Fisher, Waltham, Massachusetts). These experiments were conducted with a Stepdos reduced pulsation diaphragm-metering pump (KNF Neuberger, Trenton, New Jersey) with a polyvinylidene fluoride head, perfluorinated elastomer valves and gaskets, and PTFE-coated diaphragm. The jacketed column temperature was controlled using a Haake DC-5 (Thermo Electron, Newington, New Hampshire) re-circulating chiller/heater. 


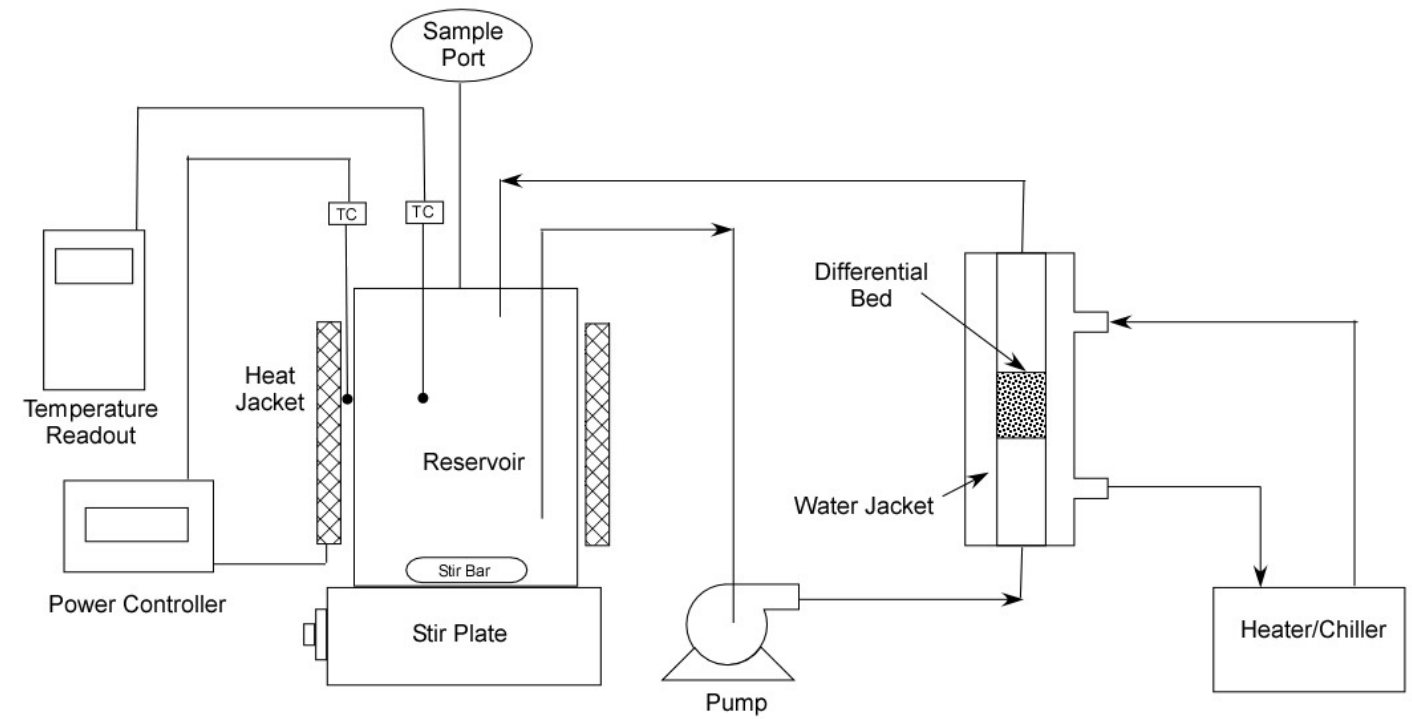

Figure 3.3. Differential Column Ion Exchange Kinetics Schematic

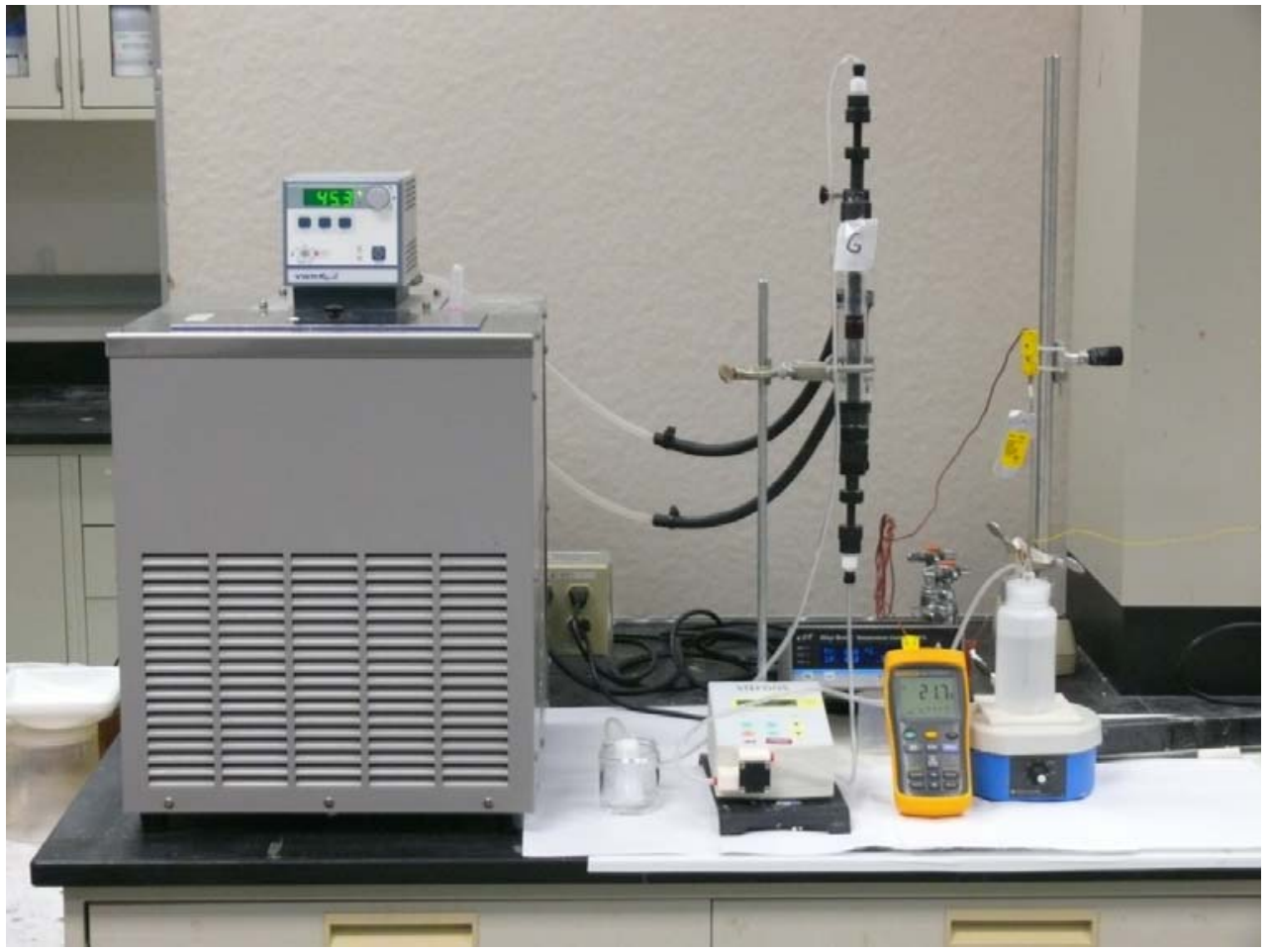

Figure 3.4. Ion Exchange Kinetics Testing Apparatus

\subsection{Column Testing Experimental Procedure}

A series of column Cs loading and elution cycles was completed as detailed in Table 3.4. The composition of the simulant used is shown in Table 3.1. The general column processing steps (e.g., pretreatment, loading, feed displacement, rinsing, elution, rinsing, and regeneration) are described in Table 3.3. 
Table 3.4. Ion Exchange Temperature Impact Experimental Design

\begin{tabular}{|c|c|c|c|c|c|c|c|c|c|c|c|}
\hline \multirow[b]{2}{*}{ Run ID ${ }^{(e)}$} & \multicolumn{7}{|c|}{ Ion Exchange Kinetic Loading Conditions } & \multicolumn{4}{|c|}{ Column Elution Conditions } \\
\hline & $\begin{array}{l}\mathrm{hr} \\
\text { (a)(b) }\end{array}$ & $\begin{array}{l}\mathrm{T} \\
{ }^{\circ} \mathrm{C}\end{array}$ & $\begin{array}{l}\mathrm{Cs}^{(\mathrm{c})} \\
\mathrm{C} / \mathrm{C}_{0}\end{array}$ & $\begin{array}{c}\text { Flow } \\
\mathrm{cm} / \mathrm{min}\end{array}$ & $\begin{array}{l}\mathrm{Na} \\
\mathrm{M}\end{array}$ & $\begin{array}{l}\mathrm{K} \\
\underline{\mathrm{M}}\end{array}$ & $\begin{array}{l}\text { Initial } \\
\text { Cs, } \underline{M}\end{array}$ & $\begin{array}{l}\mathrm{T} \\
{ }^{\circ} \mathrm{C}\end{array}$ & $\begin{array}{c}\mathrm{BV} \\
\text { (d) }\end{array}$ & $\frac{B V}{h^{(g)}}$ & $\begin{array}{c}\mathrm{HNO}_{3} \\
\underline{\mathrm{M}}^{(\mathrm{d})}\end{array}$ \\
\hline Test-4-A-1 & 10 & 45 & 0.52 & 6 & 5.0 & 0.03 & $4.51 \mathrm{E}-5$ & 25 & 25 & 2.8 & 0.25 \\
\hline Test-4-A-2 & 10 & 45 & 0.52 & 8 & 5.0 & 0.03 & $4.51 \mathrm{E}-5$ & 25 & 25 & 2.8 & 0.25 \\
\hline Test-4-A-3 & 10 & 45 & 0.52 & 4 & 5.0 & 0.03 & $4.51 \mathrm{E}-5$ & 25 & 25 & 2.8 & 0.25 \\
\hline Test-4-A-4 & 10 & 45 & 0.52 & 6 & 5.0 & 0.03 & $4.51 \mathrm{E}-5$ & 25 & NA & NA & NA \\
\hline Test-4-A-4B & 720 & 60 & 0.52 & $<0.1^{(\mathrm{f})}$ & 5.0 & 0.03 & $4.51 \mathrm{E}-5$ & 25 & 25 & 2.8 & 0.25 \\
\hline Test-4-A-5 & 10 & 45 & 0.52 & 6 & 5.0 & 0.03 & $4.51 E-5$ & 25 & 25 & 2.8 & 0.25 \\
\hline Test-4-B-1 & 10 & 40 & 0.52 & 6 & 5.0 & 0.03 & $4.51 \mathrm{E}-5$ & 25 & 25 & 2.8 & 0.25 \\
\hline Test-4-B-2 & 10 & 40 & 0.52 & 8 & 5.0 & 0.03 & $4.51 \mathrm{E}-5$ & 25 & 25 & 2.8 & 0.25 \\
\hline Test-4-B-3 & 10 & 40 & 0.52 & 4 & 5.0 & 0.03 & $4.51 \mathrm{E}-5$ & 25 & 25 & 2.8 & 0.25 \\
\hline Test-4-B-4 & 10 & 40 & 0.52 & 6 & 5.0 & 0.03 & $4.51 \mathrm{E}-5$ & 25 & NA & NA & NA \\
\hline Test-4-B-4B & 720 & 55 & 0.52 & $<0.1^{(\mathrm{f})}$ & 5.0 & 0.03 & $4.51 \mathrm{E}-5$ & 25 & 25 & 2.8 & 0.25 \\
\hline Test-4-B-5 & 10 & 40 & 0.52 & 6 & 5.0 & 0.03 & $4.51 E-5$ & 25 & 25 & 2.8 & 0.25 \\
\hline Test-4-C-1 & 10 & 30 & 0.52 & 6 & 5.0 & 0.03 & $4.51 \mathrm{E}-5$ & 25 & 25 & 2.8 & 0.25 \\
\hline Test-4-C-2 & 10 & 30 & 0.52 & 8 & 5.0 & 0.03 & $4.51 \mathrm{E}-5$ & 25 & 25 & 2.8 & 0.25 \\
\hline Test-4-C-3 & 10 & 30 & 0.52 & 4 & 5.0 & 0.03 & $4.51 \mathrm{E}-5$ & 25 & 25 & 2.8 & 0.25 \\
\hline Test-4-C-4 & 10 & 30 & 0.52 & 6 & 5.0 & 0.03 & $4.51 \mathrm{E}-5$ & 25 & NA & NA & NA \\
\hline Test-4-C-4B & 720 & 50 & 0.52 & $<0.1^{(\mathrm{f})}$ & 5.0 & 0.03 & $4.51 \mathrm{E}-5$ & 25 & 25 & 2.8 & 0.25 \\
\hline Test-4-C-5 & 10 & 30 & 0.52 & 6 & 5.0 & 0.03 & $4.51 \mathrm{E}-5$ & 25 & 25 & 2.8 & 0.25 \\
\hline Test-4-D-1 & 10 & 25 & 0.52 & 6 & 5.0 & 0.03 & $4.51 \mathrm{E}-5$ & 25 & 25 & 2.8 & 0.25 \\
\hline Test-4-D-2 & 10 & 25 & 0.52 & 8 & 5.0 & 0.03 & $4.51 \mathrm{E}-5$ & 25 & 25 & 2.8 & 0.25 \\
\hline Test-4-D-3 & 10 & 25 & 0.52 & 4 & 5.0 & 0.03 & $4.51 \mathrm{E}-5$ & 25 & 25 & 2.8 & 0.25 \\
\hline Test-4-D-4 & 10 & 25 & 0.52 & 6 & 5.0 & 0.03 & $4.51 \mathrm{E}-5$ & 25 & NA & NA & NA \\
\hline Test-4-D-4B & 720 & 45 & 0.52 & $<0.1^{(\mathrm{f})}$ & 5.0 & 0.03 & $4.51 \mathrm{E}-5$ & 25 & 25 & 2.8 & 0.25 \\
\hline Test-4-D-5 & 10 & 25 & 0.52 & 6 & 5.0 & 0.03 & $4.51 \mathrm{E}-5$ & 25 & 25 & 2.8 & 0.25 \\
\hline
\end{tabular}

(a) Resin loading is expected to require approximately $10 \mathrm{hr}$ to achieve kinetic equilibrium. Samples were collected periodically to define the cesium uptake curve (i.e., 0, 6, 12, 18, 24, 36, 48, 60, 80, 120, 180, 240, $600 \mathrm{~min}$ ).

(b) The $10 \mathrm{hr}$ kinetics tests were completed at temperatures specified for each run. Four extended duration (720 hr target) solution flow tests were completed at $45^{\circ}, 50^{\circ}, 55^{\circ}$, and $60^{\circ} \mathrm{C}$.

(c) The total simulant solution volume used was targeted to obtain an expected loading of $0.52 \mathrm{C} / \mathrm{C}_{0}$. However, this ratio was not achieved in this testing.

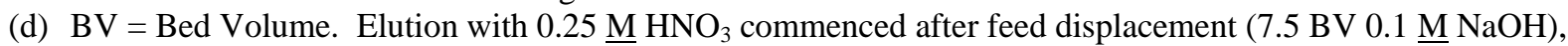
water rinse (7.5 BV DI water) and acid neutralization (3 BV 0.5 $\mathrm{M} \mathrm{HNO}_{3}$ ) solutions were passed through the column. A single elution composite sample was collected and analyzed.

(e) Each test series (e.g., A, B, C and D) represents an independent ion exchange column that was loaded and eluted one or more times using the conditions listed. The BV of the ion exchange resin was $\sim 1.8 \mathrm{~mL}$.

(f) The actual flow velocity was limited by the pump configuration and determined at the time of experimentation; however, it was estimated to be approximately $0.08 \mathrm{~cm} / \mathrm{min}$. The flow was as slow as possible to look at resin degradation.

(g) The flow rate for elution was expected to be approximately $2.8 \mathrm{BV} / \mathrm{h}$. The flow rate was approximately $5 \mathrm{~mL} / \mathrm{h}$. 
The ion exchange columns were loaded with simulant feed solution at temperatures of 25, 30, 40, 45, 50,55 , and $60 \pm 2^{\circ} \mathrm{C}$. The solution was processed at various linear flow velocities $(0.08,4,6$, and $8 \mathrm{~cm} / \mathrm{min}$ ) as shown in Table 3.4. Following Cs loading, the feed solution was displaced with $7.5 \mathrm{BV}$ of $0.1 \underline{\mathrm{M}} \mathrm{NaOH}$, rinsed with 7.5 BV of DI water, and the resin was neutralized with $3 \mathrm{BV}$ of $0.5 \underline{\mathrm{M} \mathrm{HNO}} \mathrm{HN}_{3}$ at $3 \mathrm{BV} / \mathrm{hr}$ as outlined in Table 3.3 except after the fourth cycle. After the fourth cycle, the columns weren't eluted but were then loaded with fresh simulant feed solution at a very slow flow rate $(0.08 \mathrm{~cm} / \mathrm{min})$ at a higher temperature for a target of $720 \mathrm{hr}$ to determine the effect of temperature on the resin Cs loading.

The ion exchange columns were eluted with approximately $28 \mathrm{BV}$ of $0.25 \underline{\mathrm{M}} \mathrm{HNO}_{3}$ processed at $25^{\circ} \mathrm{C}$ and at $2.8 \mathrm{BV} / \mathrm{hr}$, as shown in Table 3.4. Following elution, the columns were rinsed with $3 \mathrm{BV}$ of DI water and regenerated with $6 \mathrm{BV}$ of $0.5 \underline{\mathrm{M} \mathrm{NaOH}}$ at $3 \mathrm{BV} / \mathrm{hr}$ before beginning the next Cs loading cycle. Weights of each sample and the temperature of the simulant were recorded for each sampling.

Simulant samples were submitted to Southwest Research Institute (SwRI) for chemical analysis. Analysis methods included inductively coupled plasma-mass spectroscopy (ICP-MS) for Cs; inductively coupled plasma-optical emission spectroscopy (ICP-OES) for Na, K, and Al; ion chromatography (IC) for anions; total inorganic carbon (TIC); total organic carbon (TOC); and titration for total and free $\mathrm{OH}$ analysis. QA and quality control procedures for using blanks, duplicates, and spikes, along with standard results for each analysis set, are maintained in records and not reported here.

\subsection{Batch Loading Testing System}

A series of batch Cs loading tests was completed as detailed in Table 3.5. The composition of each feed simulant used in the loading tests is also shown in Table 3.5. The batch feed simulants were placed into $30 \mathrm{~mL}$ bottles, the required amount of resin was added to the bottles, and then the bottles were placed on an IKA KS 4000 orbital shaker table (IKA Works, Wilmington, North Carolina) with a temperature control to hold them at the specified temperature $\left(25,35\right.$, or $\left.50^{\circ} \mathrm{C}\right)$. A picture of this orbital shaker table is shown in Figure 3.5. The temperature was measured using a calibrated Type $\mathrm{K}$ thermocouple and Fluke 52II temperature readout (Fluke, Everett, Washington). The samples were rotated at $140 \mathrm{rpm}$ to ensure that samples were mixed thoroughly for the entire contact time.

\subsection{Batch Testing Experimental Procedure}

Several small batches of conditioned SRF resin were contacted with feed simulant solutions (Table 3.5) containing variable $\mathrm{Na}, \mathrm{Cs}, \mathrm{K}$, and $\mathrm{OH}$ ion concentrations. The balance of the simulant was nitrate ion. Approximately $0.1 \mathrm{~g}$ resin was contacted with $\sim 25 \mathrm{~mL}$ of feed simulant solution (phase ratio of 150:1) for $72 \mathrm{hr}$ as shown in Table 3.5 to ensure equilibrium had been reached. Samples were mixed at one of three temperatures (i.e., 25,35 and $50 \pm 2^{\circ} \mathrm{C}$ ).

Simulant samples were submitted to SwRI for the same chemical analysis as described in Section 3.7. 
Table 3.5. Sodium Impact Experimental Design

\begin{tabular}{|c|c|c|c|c|c|c|}
\hline \multirow[b]{2}{*}{ Run ID } & \multicolumn{6}{|c|}{ Ion Exchange Loading Conditions } \\
\hline & $\mathrm{hr}$ & $\begin{array}{c}\mathrm{T} \\
{ }^{\circ} \mathrm{C}\end{array}$ & $\begin{array}{l}\mathrm{Na} \\
\underline{\mathrm{M}}\end{array}$ & $\begin{array}{c}\mathrm{OH} \\
\underline{\mathrm{M}}\end{array}$ & $\begin{array}{l}\text { Initial } \\
\text { Cs, } \underline{M}\end{array}$ & $\begin{array}{l}\mathrm{K} \\
\mathrm{M}\end{array}$ \\
\hline Test-5-Na-A1 & 72 & 50 & 0.1 & 0.1 & $5.0 \mathrm{E}-06$ & 0.005 \\
\hline Test-5-Na-A2 & 72 & 50 & 0.5 & 0.1 & 5.0E-06 & 0.005 \\
\hline Test-5-Na-A3 & 72 & 50 & 0.75 & 0.1 & 5.0E-06 & 0.005 \\
\hline Test-5-Na-A4 & 72 & 50 & 1.0 & 0.1 & 5.0E-06 & 0.005 \\
\hline Test-5-Na-A5 & 72 & 50 & 3.0 & 0.1 & 5.0E-06 & 0.005 \\
\hline Test-5-Na-A6 & 72 & 50 & 5.0 & 0.1 & $5.0 \mathrm{E}-06$ & 0.005 \\
\hline Test-5-Na-B1 & 72 & 50 & 0.1 & 0.1 & 5.0E-06 & 0.05 \\
\hline Test-5-Na-B2 & 72 & 50 & 0.5 & 0.1 & 5.0E-06 & 0.05 \\
\hline Test-5-Na-B3 & 72 & 50 & 0.75 & 0.1 & 5.0E-06 & 0.05 \\
\hline Test-5-Na-B4 & 72 & 50 & 1.0 & 0.1 & 5.0E-06 & 0.05 \\
\hline Test-5-Na-B5 & 72 & 50 & 3.0 & 0.1 & $5.0 \mathrm{E}-06$ & 0.05 \\
\hline Test-5-Na-B6 & 72 & 50 & 5.0 & 0.1 & 5.0E-06 & 0.05 \\
\hline Test-5-Na-C1 & 72 & 50 & 1.0 & 1 & $5.0 \mathrm{E}-06$ & 0.005 \\
\hline Test-5-Na-C2 & 72 & 50 & 3.0 & 1 & 5.0E-06 & 0.005 \\
\hline Test-5-Na-C3 & 72 & 50 & 5.0 & 1 & 5.0E-06 & 0.005 \\
\hline Test-5-Na-D1 & 72 & 50 & 1.0 & 1 & 5.0E-06 & 0.05 \\
\hline Test-5-Na-D2 & 72 & 50 & 3.0 & 1 & $5.0 \mathrm{E}-06$ & 0.05 \\
\hline Test-5-Na-D3 & 72 & 50 & 5.0 & 1 & 5.0E-06 & 0.05 \\
\hline Test-5-Na-E1 & 72 & 25 & 0.1 & 0.1 & 5.0E-06 & 0.005 \\
\hline Test-5-Na-E2 & 72 & 25 & 0.5 & 0.1 & 5.0E-06 & 0.005 \\
\hline Test-5-Na-E3 & 72 & 25 & 0.75 & 0.1 & $5.0 \mathrm{E}-06$ & 0.005 \\
\hline Test-5-Na-E4 & 72 & 25 & 1.0 & 0.1 & $5.0 \mathrm{E}-06$ & 0.005 \\
\hline Test-5-Na-E5 & 72 & 25 & 3.0 & 0.1 & $5.0 \mathrm{E}-06$ & 0.005 \\
\hline Test-5-Na-E6 & 72 & 25 & 5.0 & 0.1 & 5.0E-06 & 0.005 \\
\hline Test-5-Na-F1 & 72 & 25 & 0.1 & 0.1 & 5.0E-06 & 0.05 \\
\hline Test-5-Na-F2 & 72 & 25 & 0.5 & 0.1 & 5.0E-06 & 0.05 \\
\hline Test-5-Na-F3 & 72 & 25 & 0.75 & 0.1 & $5.0 \mathrm{E}-06$ & 0.05 \\
\hline Test-5-Na-F4 & 72 & 25 & 1.0 & 0.1 & 5.0E-06 & 0.05 \\
\hline Test-5-Na-F5 & 72 & 25 & 3.0 & 0.1 & 5.0E-06 & 0.05 \\
\hline Test-5-Na-F6 & 72 & 25 & 5.0 & 0.1 & 5.0E-06 & 0.05 \\
\hline Test-5-Na-G1 & 72 & 25 & 1.0 & 1 & 5.0E-06 & 0.005 \\
\hline Test-5-Na-G2 & 72 & 25 & 3.0 & 1 & 5.0E-06 & 0.005 \\
\hline Test-5-Na-G3 & 72 & 25 & 5.0 & 1 & 5.0E-06 & 0.005 \\
\hline Test-5-Na-H1 & 72 & 25 & 1.0 & 1 & 5.0E-06 & 0.05 \\
\hline Test-5-Na-H2 & 72 & 25 & 3.0 & 1 & $5.0 \mathrm{E}-06$ & 0.05 \\
\hline Test-5-Na-H3 & 72 & 25 & 5.0 & 1 & 5.0E-06 & 0.05 \\
\hline Test-5-Na-I1 & 72 & 50 & 0.1 & 0.1 & 5.0E-05 & 0.005 \\
\hline Test-5-Na-I2 & 72 & 50 & 0.5 & 0.1 & $5.0 \mathrm{E}-05$ & 0.005 \\
\hline Test-5-Na-I3 & 72 & 50 & 0.75 & 0.1 & 5.0E-05 & 0.005 \\
\hline Test-5-Na-I4 & 72 & 50 & 1.0 & 0.1 & 5.0E-05 & 0.005 \\
\hline
\end{tabular}


Table 3.5. (contd)

\begin{tabular}{|c|c|c|c|c|c|c|}
\hline \multirow[b]{2}{*}{ Run ID } & \multicolumn{6}{|c|}{ Ion Exchange Loading Conditions } \\
\hline & $\mathrm{hr}$ & $\begin{array}{c}\mathrm{T} \\
{ }^{\circ} \mathrm{C}\end{array}$ & $\begin{array}{l}\mathrm{Na} \\
\mathrm{M}\end{array}$ & $\begin{array}{c}\mathrm{OH} \\
\mathrm{M}\end{array}$ & $\begin{array}{l}\text { Initial } \\
\text { Cs, } \underline{M}\end{array}$ & $\begin{array}{l}\mathrm{K} \\
\mathrm{M}\end{array}$ \\
\hline Test-5-Na-I5 & 72 & 50 & 3.0 & 0.1 & $5.0 \mathrm{E}-05$ & 0.005 \\
\hline Test-5-Na-I6 & 72 & 50 & 5.0 & 0.1 & $5.0 \mathrm{E}-05$ & 0.005 \\
\hline Test-5-Na-J1 & 72 & 50 & 0.1 & 0.1 & $5.0 \mathrm{E}-05$ & 0.05 \\
\hline Test-5-Na-J2 & 72 & 50 & 0.5 & 0.1 & $5.0 \mathrm{E}-05$ & 0.05 \\
\hline Test-5-Na-J3 & 72 & 50 & 0.75 & 0.1 & $5.0 \mathrm{E}-05$ & 0.05 \\
\hline Test-5-Na-J4 & 72 & 50 & 1.0 & 0.1 & $5.0 \mathrm{E}-05$ & 0.05 \\
\hline Test-5-Na-J5 & 72 & 50 & 3.0 & 0.1 & $5.0 \mathrm{E}-05$ & 0.05 \\
\hline Test-5-Na-J6 & 72 & 50 & 5.0 & 0.1 & $5.0 \mathrm{E}-05$ & 0.05 \\
\hline Test-5-Na-K1 & 72 & 50 & 1.0 & 1 & $5.0 \mathrm{E}-05$ & 0.005 \\
\hline Test-5-Na-K2 & 72 & 50 & 3.0 & 1 & $5.0 \mathrm{E}-05$ & 0.005 \\
\hline Test-5-Na-K3 & 72 & 50 & 5.0 & 1 & $5.0 \mathrm{E}-05$ & 0.005 \\
\hline Test-5-Na-L1 & 72 & 50 & 1.0 & 1 & $5.0 \mathrm{E}-05$ & 0.05 \\
\hline Test-5-Na-L2 & 72 & 50 & 3.0 & 1 & $5.0 \mathrm{E}-05$ & 0.05 \\
\hline Test-5-Na-L3 & 72 & 50 & 5.0 & 1 & $5.0 \mathrm{E}-05$ & 0.05 \\
\hline Test-5-Na-M1 & 72 & 25 & 0.1 & 0.1 & $5.0 \mathrm{E}-05$ & 0.005 \\
\hline Test-5-Na-M2 & 72 & 25 & 0.5 & 0.1 & $5.0 \mathrm{E}-05$ & 0.005 \\
\hline Test-5-Na-M3 & 72 & 25 & 0.75 & 0.1 & $5.0 \mathrm{E}-05$ & 0.005 \\
\hline Test-5-Na-M4 & 72 & 25 & 1.0 & 0.1 & $5.0 \mathrm{E}-05$ & 0.005 \\
\hline Test-5-Na-M5 & 72 & 25 & 3.0 & 0.1 & $5.0 \mathrm{E}-05$ & 0.005 \\
\hline Test-5-Na-M6 & 72 & 25 & 5.0 & 0.1 & $5.0 \mathrm{E}-05$ & 0.005 \\
\hline Test-5-Na-N1 & 72 & 25 & 0.1 & 0.1 & $5.0 \mathrm{E}-05$ & 0.05 \\
\hline Test-5-Na-N2 & 72 & 25 & 0.5 & 0.1 & $5.0 \mathrm{E}-05$ & 0.05 \\
\hline Test-5-Na-N3 & 72 & 25 & 0.75 & 0.1 & $5.0 \mathrm{E}-05$ & 0.05 \\
\hline Test-5-Na-N4 & 72 & 25 & 1.0 & 0.1 & $5.0 \mathrm{E}-05$ & 0.05 \\
\hline Test-5-Na-N5 & 72 & 25 & 3.0 & 0.1 & $5.0 \mathrm{E}-05$ & 0.05 \\
\hline Test-5-Na-N6 & 72 & 25 & 5.0 & 0.1 & $5.0 \mathrm{E}-05$ & 0.05 \\
\hline Test-5-Na-O1 & 72 & 25 & 1.0 & 1 & $5.0 \mathrm{E}-05$ & 0.005 \\
\hline Test-5-Na-O2 & 72 & 25 & 3.0 & 1 & $5.0 \mathrm{E}-05$ & 0.005 \\
\hline Test-5-Na-O3 & 72 & 25 & 5.0 & 1 & $5.0 \mathrm{E}-05$ & 0.005 \\
\hline Test-5-Na-P1 & 72 & 25 & 1.0 & 1 & $5.0 \mathrm{E}-05$ & 0.05 \\
\hline Test-5-Na-P2 & 72 & 25 & 3.0 & 1 & $5.0 \mathrm{E}-05$ & 0.05 \\
\hline Test-5-Na-P3 & 72 & 25 & 5.0 & 1 & $5.0 \mathrm{E}-05$ & 0.05 \\
\hline Test-5-Na-Q1 & 72 & 50 & 0.1 & 0.1 & $5.0 \mathrm{E}-04$ & 0.005 \\
\hline Test-5-Na-Q2 & 72 & 50 & 0.5 & 0.1 & $5.0 \mathrm{E}-04$ & 0.005 \\
\hline Test-5-Na-Q3 & 72 & 50 & 0.75 & 0.1 & $5.0 \mathrm{E}-04$ & 0.005 \\
\hline Test-5-Na-Q4 & 72 & 50 & 1.0 & 0.1 & $5.0 \mathrm{E}-04$ & 0.005 \\
\hline Test-5-Na-Q5 & 72 & 50 & 3.0 & 0.1 & $5.0 \mathrm{E}-04$ & 0.005 \\
\hline Test-5-Na-Q6 & 72 & 50 & 5.0 & 0.1 & $5.0 \mathrm{E}-04$ & 0.005 \\
\hline Test-5-Na-R1 & 72 & 50 & 0.1 & 0.1 & $5.0 \mathrm{E}-04$ & 0.05 \\
\hline Test-5-Na-R2 & 72 & 50 & 0.5 & 0.1 & $5.0 \mathrm{E}-04$ & 0.05 \\
\hline Test-5-Na-R3 & 72 & 50 & 0.75 & 0.1 & $5.0 \mathrm{E}-04$ & 0.05 \\
\hline Test-5-Na-R4 & 72 & 50 & 1.0 & 0.1 & $5.0 \mathrm{E}-04$ & 0.05 \\
\hline Test-5-Na-R5 & 72 & 50 & 3.0 & 0.1 & $5.0 \mathrm{E}-04$ & 0.05 \\
\hline Test-5-Na-R6 & 72 & 50 & 5.0 & 0.1 & $5.0 \mathrm{E}-04$ & 0.05 \\
\hline Test-5-Na-S1 & 72 & 50 & 1.0 & 1 & $5.0 \mathrm{E}-04$ & 0.005 \\
\hline
\end{tabular}


Table 3.5. (contd)

\begin{tabular}{|c|c|c|c|c|c|c|}
\hline \multirow[b]{2}{*}{ Run ID } & \multicolumn{6}{|c|}{ Ion Exchange Loading Conditions } \\
\hline & $\mathrm{hr}$ & $\begin{array}{c}\mathrm{T} \\
{ }^{\circ} \mathrm{C}\end{array}$ & $\begin{array}{l}\mathrm{Na} \\
\mathrm{M}\end{array}$ & $\begin{array}{c}\mathrm{OH} \\
\mathrm{M}\end{array}$ & $\begin{array}{l}\text { Initial } \\
\text { Cs, } \underline{M}\end{array}$ & $\begin{array}{l}\mathrm{K} \\
\mathrm{M}\end{array}$ \\
\hline Test-5-Na-S2 & 72 & 50 & 3.0 & 1 & $5.0 \mathrm{E}-04$ & 0.005 \\
\hline Test-5-Na-S3 & 72 & 50 & 5.0 & 1 & $5.0 \mathrm{E}-04$ & 0.005 \\
\hline Test-5-Na-T1 & 72 & 50 & 1.0 & 1 & $5.0 \mathrm{E}-04$ & 0.05 \\
\hline Test-5-Na-T2 & 72 & 50 & 3.0 & 1 & $5.0 \mathrm{E}-04$ & 0.05 \\
\hline Test-5-Na-T3 & 72 & 50 & 5.0 & 1 & $5.0 \mathrm{E}-04$ & 0.05 \\
\hline Test-5-Na-U1 & 72 & 25 & 0.1 & 0.1 & $5.0 \mathrm{E}-04$ & 0.005 \\
\hline Test-5-Na-U2 & 72 & 25 & 0.5 & 0.1 & $5.0 \mathrm{E}-04$ & 0.005 \\
\hline Test-5-Na-U3 & 72 & 25 & 0.75 & 0.1 & $5.0 \mathrm{E}-04$ & 0.005 \\
\hline Test-5-Na-U4 & 72 & 25 & 1.0 & 0.1 & $5.0 \mathrm{E}-04$ & 0.005 \\
\hline Test-5-Na-U5 & 72 & 25 & 3.0 & 0.1 & $5.0 \mathrm{E}-04$ & 0.005 \\
\hline Test-5-Na-U6 & 72 & 25 & 5.0 & 0.1 & $5.0 \mathrm{E}-04$ & 0.005 \\
\hline Test-5-Na-V1 & 72 & 25 & 0.1 & 0.1 & $5.0 \mathrm{E}-04$ & 0.05 \\
\hline Test-5-Na-V2 & 72 & 25 & 0.5 & 0.1 & $5.0 \mathrm{E}-04$ & 0.05 \\
\hline Test-5-Na-V3 & 72 & 25 & 0.75 & 0.1 & $5.0 \mathrm{E}-04$ & 0.05 \\
\hline Test-5-Na-V4 & 72 & 25 & 1.0 & 0.1 & $5.0 \mathrm{E}-04$ & 0.05 \\
\hline Test-5-Na-V5 & 72 & 25 & 3.0 & 0.1 & $5.0 \mathrm{E}-04$ & 0.05 \\
\hline Test-5-Na-V6 & 72 & 25 & 5.0 & 0.1 & $5.0 \mathrm{E}-04$ & 0.05 \\
\hline Test-5-Na-W1 & 72 & 25 & 1.0 & 1 & $5.0 \mathrm{E}-04$ & 0.005 \\
\hline Test-5-Na-W2 & 72 & 25 & 3.0 & 1 & $5.0 \mathrm{E}-04$ & 0.005 \\
\hline Test-5-Na-W3 & 72 & 25 & 5.0 & 1 & $5.0 \mathrm{E}-04$ & 0.005 \\
\hline Test-5-Na-X1 & 72 & 25 & 1.0 & 1 & $5.0 \mathrm{E}-04$ & 0.05 \\
\hline Test-5-Na-X2 & 72 & 25 & 3.0 & 1 & $5.0 \mathrm{E}-04$ & 0.05 \\
\hline Test-5-Na-X3 & 72 & 25 & 5.0 & 1 & $5.0 \mathrm{E}-04$ & 0.05 \\
\hline Test-5-Na-Y1 & 72 & 50 & 0.1 & 0.1 & $5.0 \mathrm{E}-03$ & 0.005 \\
\hline Test-5-Na-Y2 & 72 & 50 & 0.5 & 0.1 & $5.0 \mathrm{E}-03$ & 0.005 \\
\hline Test-5-Na-Y3 & 72 & 50 & 0.75 & 0.1 & $5.0 \mathrm{E}-03$ & 0.005 \\
\hline Test-5-Na-Y4 & 72 & 50 & 1.0 & 0.1 & $5.0 \mathrm{E}-03$ & 0.005 \\
\hline Test-5-Na-Y5 & 72 & 50 & 3.0 & 0.1 & $5.0 \mathrm{E}-03$ & 0.005 \\
\hline Test-5-Na-Y6 & 72 & 50 & 5.0 & 0.1 & $5.0 \mathrm{E}-03$ & 0.005 \\
\hline Test-5-Na-Z1 & 72 & 50 & 0.1 & 0.1 & $5.0 \mathrm{E}-03$ & 0.05 \\
\hline Test-5-Na-Z2 & 72 & 50 & 0.5 & 0.1 & $5.0 \mathrm{E}-03$ & 0.05 \\
\hline Test-5-Na-Z3 & 72 & 50 & 0.75 & 0.1 & $5.0 \mathrm{E}-03$ & 0.05 \\
\hline Test-5-Na-Z4 & 72 & 50 & 1.0 & 0.1 & $5.0 \mathrm{E}-03$ & 0.05 \\
\hline Test-5-Na-Z5 & 72 & 50 & 3.0 & 0.1 & $5.0 \mathrm{E}-03$ & 0.05 \\
\hline Test-5-Na-Z6 & 72 & 50 & 5.0 & 0.1 & $5.0 \mathrm{E}-03$ & 0.05 \\
\hline Test-5-Na-AA1 & 72 & 50 & 1.0 & 1 & $5.0 \mathrm{E}-03$ & 0.005 \\
\hline Test-5-Na-AA2 & 72 & 50 & 3.0 & 1 & $5.0 \mathrm{E}-03$ & 0.005 \\
\hline Test-5-Na-AA3 & 72 & 50 & 5.0 & 1 & $5.0 \mathrm{E}-03$ & 0.005 \\
\hline Test-5-Na-BB1 & 72 & 50 & 1.0 & 1 & $5.0 \mathrm{E}-03$ & 0.05 \\
\hline Test-5-Na-BB2 & 72 & 50 & 3.0 & 1 & $5.0 \mathrm{E}-03$ & 0.05 \\
\hline Test-5-Na-BB3 & 72 & 50 & 5.0 & 1 & $5.0 \mathrm{E}-03$ & 0.05 \\
\hline Test-5-Na-CC1 & 72 & 25 & 0.1 & 0.1 & $5.0 \mathrm{E}-03$ & 0.005 \\
\hline Test-5-Na-CC2 & 72 & 25 & 0.5 & 0.1 & $5.0 \mathrm{E}-03$ & 0.005 \\
\hline Test-5-Na-CC3 & 72 & 25 & 0.75 & 0.1 & $5.0 \mathrm{E}-03$ & 0.005 \\
\hline Test-5-Na-CC4 & 72 & 25 & 1.0 & 0.1 & $5.0 \mathrm{E}-03$ & 0.005 \\
\hline
\end{tabular}


Table 3.5. (contd)

\begin{tabular}{|c|c|c|c|c|c|c|}
\hline \multirow[b]{2}{*}{ Run ID } & \multicolumn{6}{|c|}{ Ion Exchange Loading Conditions } \\
\hline & $\mathrm{hr}$ & $\begin{array}{c}\mathrm{T} \\
{ }^{\circ} \mathrm{C}\end{array}$ & $\begin{array}{l}\mathrm{Na} \\
\mathrm{M}\end{array}$ & $\begin{array}{c}\mathrm{OH} \\
\mathrm{M}\end{array}$ & $\begin{array}{l}\text { Initial } \\
\text { Cs, } \underline{M}\end{array}$ & $\begin{array}{l}\mathrm{K} \\
\mathrm{M}\end{array}$ \\
\hline Test-5-Na-CC5 & 72 & 25 & 3.0 & 0.1 & $5.0 \mathrm{E}-03$ & 0.005 \\
\hline Test-5-Na-CC6 & 72 & 25 & 5.0 & 0.1 & $5.0 \mathrm{E}-03$ & 0.005 \\
\hline Test-5-Na-DD1 & 72 & 25 & 0.1 & 0.1 & $5.0 \mathrm{E}-03$ & 0.05 \\
\hline Test-5-Na-DD2 & 72 & 25 & 0.5 & 0.1 & $5.0 \mathrm{E}-03$ & 0.05 \\
\hline Test-5-Na-DD3 & 72 & 25 & 0.75 & 0.1 & $5.0 \mathrm{E}-03$ & 0.05 \\
\hline Test-5-Na-DD4 & 72 & 25 & 1.0 & 0.1 & $5.0 \mathrm{E}-03$ & 0.05 \\
\hline Test-5-Na-DD5 & 72 & 25 & 3.0 & 0.1 & $5.0 \mathrm{E}-03$ & 0.05 \\
\hline Test-5-Na-DD6 & 72 & 25 & 5.0 & 0.1 & $5.0 \mathrm{E}-03$ & 0.05 \\
\hline Test-5-Na-EE1 & 72 & 25 & 1.0 & 1 & $5.0 \mathrm{E}-03$ & 0.005 \\
\hline Test-5-Na-EE2 & 72 & 25 & 3.0 & 1 & $5.0 \mathrm{E}-03$ & 0.005 \\
\hline Test-5-Na-EE3 & 72 & 25 & 5.0 & 1 & $5.0 \mathrm{E}-03$ & 0.005 \\
\hline Test-5-Na-FF1 & 72 & 25 & 1.0 & 1 & $5.0 \mathrm{E}-03$ & 0.05 \\
\hline Test-5-Na-FF2 & 72 & 25 & 3.0 & 1 & $5.0 \mathrm{E}-03$ & 0.05 \\
\hline Test-5-Na-FF3 & 72 & 25 & 5.0 & 1 & $5.0 \mathrm{E}-03$ & 0.05 \\
\hline Test-5-Na-GG1 & 72 & 35 & 5.0 & 1 & $5.0 \mathrm{E}-03$ & 0.05 \\
\hline Test-5-Na-GG2 & 72 & 35 & 5.0 & 1 & $5.0 \mathrm{E}-04$ & 0.05 \\
\hline Test-5-Na-GG3 & 72 & 35 & 5.0 & 1 & $5.0 \mathrm{E}-05$ & 0.05 \\
\hline Test-5-Na-GG4 & 72 & 35 & 5.0 & 1 & $5.0 \mathrm{E}-06$ & 0.05 \\
\hline Test-5-Na-HH1 & 72 & 35 & 5.0 & 1 & $5.0 \mathrm{E}-03$ & 0.005 \\
\hline Test-5-Na-HH2 & 72 & 35 & 5.0 & 1 & $5.0 \mathrm{E}-04$ & 0.005 \\
\hline Test-5-Na-HH3 & 72 & 35 & 5.0 & 1 & $5.0 \mathrm{E}-05$ & 0.005 \\
\hline Test-5-Na-HH4 & 72 & 35 & 5.0 & 1 & $5.0 \mathrm{E}-06$ & 0.005 \\
\hline Test-5-Na-II1 & 72 & 35 & 0.5 & 0.1 & $5.0 \mathrm{E}-03$ & 0.05 \\
\hline Test-5-Na-II2 & 72 & 35 & 0.5 & 0.1 & $5.0 \mathrm{E}-04$ & 0.05 \\
\hline Test-5-Na-II3 & 72 & 35 & 0.5 & 0.1 & $5.0 \mathrm{E}-05$ & 0.05 \\
\hline Test-5-Na-II4 & 72 & 35 & 0.5 & 0.1 & $5.0 \mathrm{E}-06$ & 0.05 \\
\hline Test-5-Na-JJ1 & 72 & 35 & 0.5 & 0.1 & $5.0 \mathrm{E}-03$ & 0.005 \\
\hline Test-5-Na-JJ2 & 72 & 35 & 0.5 & 0.1 & $5.0 \mathrm{E}-04$ & 0.005 \\
\hline Test-5-Na-JJ3 & 72 & 35 & 0.5 & 0.1 & $5.0 \mathrm{E}-05$ & 0.005 \\
\hline Test-5-Na-JJ4 & 72 & 35 & 0.5 & 0.1 & $5.0 \mathrm{E}-06$ & 0.005 \\
\hline Test-5-Na-KK1 & 72 & 35 & 3.0 & 1 & $5.0 \mathrm{E}-04$ & 0.05 \\
\hline Test-5-Na-KK2 & 72 & 35 & 3.0 & 1 & $5.0 \mathrm{E}-03$ & 0.05 \\
\hline Test-5-Na-LL1 & 72 & 50 & 0.1 & 0.1 & $5.0 \mathrm{E}-06$ & 0.005 \\
\hline Test-5-Na-LL2 & 72 & 50 & 0.5 & 0.1 & $5.0 \mathrm{E}-06$ & 0.005 \\
\hline Test-5-Na-LL3 & 72 & 50 & 0.75 & 0.1 & $5.0 \mathrm{E}-06$ & 0.005 \\
\hline Test-5-Na-LL4 & 72 & 50 & 1.0 & 0.1 & $5.0 \mathrm{E}-06$ & 0.005 \\
\hline Test-5-Na-LL5 & 72 & 50 & 3.0 & 0.1 & $5.0 \mathrm{E}-06$ & 0.005 \\
\hline Test-5-Na-LL6 & 72 & 50 & 5.0 & 0.1 & $5.0 \mathrm{E}-06$ & 0.005 \\
\hline Test-5-Na-MM1 & 72 & 50 & 0.1 & 0.1 & $5.0 \mathrm{E}-06$ & 0.05 \\
\hline Test-5-Na-MM2 & 72 & 50 & 0.5 & 0.1 & $5.0 \mathrm{E}-06$ & 0.05 \\
\hline Test-5-Na-MM3 & 72 & 50 & 0.75 & 0.1 & $5.0 \mathrm{E}-06$ & 0.05 \\
\hline Test-5-Na-MM4 & 72 & 50 & 1.0 & 0.1 & $5.0 \mathrm{E}-06$ & 0.05 \\
\hline Test-5-Na-MM5 & 72 & 50 & 3.0 & 0.1 & $5.0 \mathrm{E}-06$ & 0.05 \\
\hline Test-5-Na-MM6 & 72 & 50 & 5.0 & 0.1 & $5.0 \mathrm{E}-06$ & 0.05 \\
\hline Test-5-Na-NN1 & 72 & 50 & 1.0 & 1 & $5.0 \mathrm{E}-06$ & 0.005 \\
\hline
\end{tabular}


Table 3.5. (contd)

\begin{tabular}{|c|c|c|c|c|c|c|}
\hline \multirow[b]{2}{*}{ Run ID } & \multicolumn{6}{|c|}{ Ion Exchange Loading Conditions } \\
\hline & $\mathrm{hr}$ & $\begin{array}{c}\mathrm{T} \\
{ }^{\circ} \mathrm{C}\end{array}$ & $\begin{array}{l}\mathrm{Na} \\
\mathrm{M}\end{array}$ & $\begin{array}{c}\mathrm{OH} \\
\mathrm{M}\end{array}$ & $\begin{array}{l}\text { Initial } \\
\text { Cs, } \underline{M}\end{array}$ & $\begin{array}{l}\mathrm{K} \\
\mathrm{M}\end{array}$ \\
\hline Test-5-Na-NN2 & 72 & 50 & 3.0 & 1 & $5.0 \mathrm{E}-06$ & 0.005 \\
\hline Test-5-Na-NN3 & 72 & 50 & 5.0 & 1 & $5.0 \mathrm{E}-06$ & 0.005 \\
\hline Test-5-Na-OO1 & 72 & 50 & 1.0 & 1 & $5.0 \mathrm{E}-06$ & 0.05 \\
\hline Test-5-Na-OO2 & 72 & 50 & 3.0 & 1 & $5.0 \mathrm{E}-06$ & 0.05 \\
\hline Test-5-Na-OO3 & 72 & 50 & 5.0 & 1 & $5.0 \mathrm{E}-06$ & 0.05 \\
\hline Test-5-Na-PP1 & 72 & 35 & 5.0 & 1 & $5.0 \mathrm{E}-06$ & 0.05 \\
\hline Test-5-Na-PP2 & 72 & 35 & 5.0 & 1 & $5.0 \mathrm{E}-06$ & 0.005 \\
\hline Test-5-Na-PP3 & 72 & 35 & 0.5 & 0.1 & $5.0 \mathrm{E}-06$ & 0.05 \\
\hline Test-5-Na-PP4 & 72 & 35 & 0.5 & 0.1 & $5.0 \mathrm{E}-06$ & 0.005 \\
\hline Test-5-Na-QQ1 & 72 & 25 & 0.1 & 0.1 & $5.0 \mathrm{E}-06$ & 0.005 \\
\hline Test-5-Na-QQ2 & 72 & 25 & 0.5 & 0.1 & $5.0 \mathrm{E}-06$ & 0.005 \\
\hline Test-5-Na-QQ3 & 72 & 25 & 0.75 & 0.1 & $5.0 \mathrm{E}-06$ & 0.005 \\
\hline Test-5-Na-QQ4 & 72 & 25 & 1.0 & 0.1 & $5.0 \mathrm{E}-06$ & 0.005 \\
\hline Test-5-Na-QQ5 & 72 & 25 & 3.0 & 0.1 & $5.0 \mathrm{E}-06$ & 0.005 \\
\hline Test-5-Na-QQ6 & 72 & 25 & 5.0 & 0.1 & $5.0 \mathrm{E}-06$ & 0.005 \\
\hline Test-5-Na-RR1 & 72 & 25 & 0.1 & 0.1 & $5.0 \mathrm{E}-06$ & 0.05 \\
\hline Test-5-Na-RR2 & 72 & 25 & 0.5 & 0.1 & $5.0 \mathrm{E}-06$ & 0.05 \\
\hline Test-5-Na-RR3 & 72 & 25 & 0.75 & 0.1 & $5.0 \mathrm{E}-06$ & 0.05 \\
\hline Test-5-Na-RR4 & 72 & 25 & 1.0 & 0.1 & $5.0 \mathrm{E}-06$ & 0.05 \\
\hline Test-5-Na-RR5 & 72 & 25 & 3.0 & 0.1 & $5.0 \mathrm{E}-06$ & 0.05 \\
\hline Test-5-Na-RR6 & 72 & 25 & 5.0 & 0.1 & $5.0 \mathrm{E}-06$ & 0.05 \\
\hline Test-5-Na-SS1 & 72 & 25 & 1.0 & 1 & $5.0 \mathrm{E}-06$ & 0.005 \\
\hline Test-5-Na-SS2 & 72 & 25 & 3.0 & 1 & $5.0 \mathrm{E}-06$ & 0.005 \\
\hline Test-5-Na-SS3 & 72 & 25 & 5.0 & 1 & $5.0 \mathrm{E}-06$ & 0.005 \\
\hline Test-5-Na-TT1 & 72 & 25 & 1.0 & 1 & $5.0 \mathrm{E}-06$ & 0.05 \\
\hline Test-5-Na-TT2 & 72 & 25 & 3.0 & 1 & $5.0 \mathrm{E}-06$ & 0.05 \\
\hline Test-5-Na-TT3 & 72 & 25 & 5.0 & 1 & $5.0 \mathrm{E}-06$ & 0.05 \\
\hline
\end{tabular}




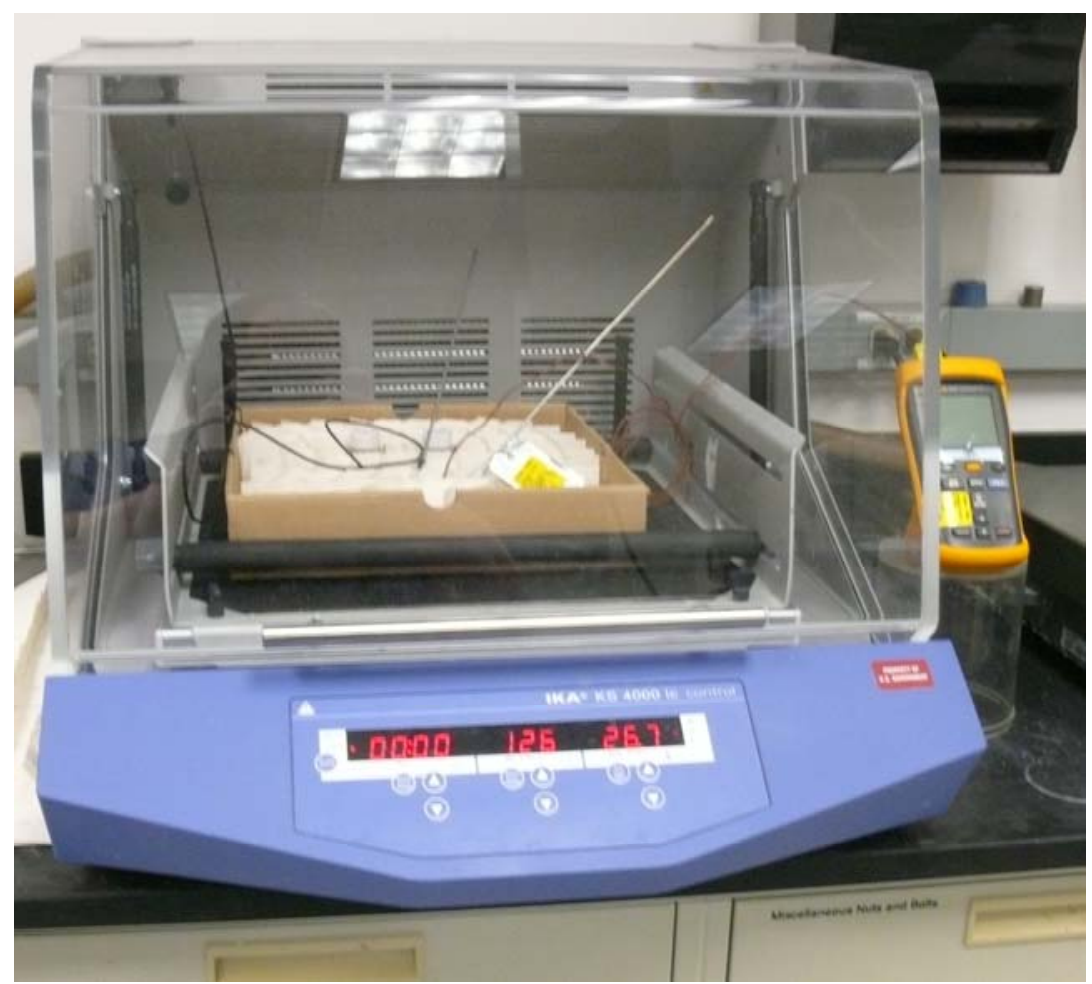

Figure 3.5. Batch Cs Loading Temperature Controlled Orbital Shaker Table 


\subsection{Results and Discussion}

This research examined the impact of linear load velocity $(4,6,8 \mathrm{~cm} / \mathrm{min})$ and temperature $(25,30$, $40,45^{\circ} \mathrm{C}$ ) on the Cs loading kinetics in columns. The resin degradation during extended solution flow at elevated temperatures $\left(45,50,55,60^{\circ} \mathrm{C}\right)$ was also studied using columns. The effect of the initial $\mathrm{Na}$ concentration $(0.1,0.5,0.75,1,3,5 \underline{\mathrm{M}})$, initial $\mathrm{K}$ concentration $(0.005$ and $0.05 \underline{\mathrm{M}})$, and free $\mathrm{OH}$ concentration ( 0.1 and $1 \underline{\mathrm{M}}$ ) on the resin's Cs loading capacity at temperatures of 25,35 , and $50^{\circ} \mathrm{C}$ was tested using batch tests. The results of this research are discussed in this section.

\subsection{Impacts of Linear Load Velocity and Temperature on Resin Cs Loading Kinetics}

A series of column Cs loading and elution cycles were completed using the test matrix as detailed in Table 3.4. The axial velocity and temperature were the primary variables studied. Test results were then compared.

Tests performed at varying linear load velocities provided a measurement of the impact of the film mass transfer coefficient on the Cs loading kinetics. The overall effect of the linear load velocity was considered insignificant on the Cs loading kinetics as shown in Figure 4.1 through Figure 4.4. However, as the temperature increased, the impact of velocity began to increase as well. Previous work showed a greater effect of the loading velocity on the Cs loading when performed at $45^{\circ} \mathrm{C}$ to $60^{\circ} \mathrm{C}$ (Russell et al. 2012). The decrease in the impact of velocity with decreasing temperature is somewhat expected. As temperature is decreased, the kinetics of the sorption process will decrease. It would appear that below $45^{\circ} \mathrm{C}$, the sorption process becomes the dominant factor in the Cs loading in place of the mass transfer process, which results in velocity not having a significant effect.

It was also seen that the lower the temperature, the greater the effect of the linear load velocity on Cs loading. At $45^{\circ} \mathrm{C}$ the $\mathrm{Cs}$ loading is essentially the same, but at the lower temperatures, the Cs loading is slightly higher with the lower linear load velocity. This may be due to competing effects on the resin. The higher temperature is decreasing the Cs loading while the lower linear load velocity is increasing the Cs loading. At $45^{\circ} \mathrm{C}$, they cancel each other resulting in no effect on the Cs loading. However, at lower temperatures, the effect of the lower linear velocity is higher than the effect of the temperature which results in a slightly increased Cs loading. Lower linear load velocity allows more time for diffusion into the ion exchange particles and has been noted in previous work (Smith et al. 2009, Smith et al. 2007, and King et al. 2004).

It was found that temperature under these conditions had a slightly positive effect with the Cs loading kinetics increasing slightly with temperature as expected. The $25^{\circ} \mathrm{C}$ and $30^{\circ} \mathrm{C}$ tests were essentially the same and the $40^{\circ} \mathrm{C}$ and $45^{\circ} \mathrm{C}$ tests were essentially the same. However, there was a slight increase in the kinetics between the $30^{\circ} \mathrm{C}$ and $40^{\circ} \mathrm{C}$ tests. These results are shown in Figure 4.5 through Figure 4.7. 


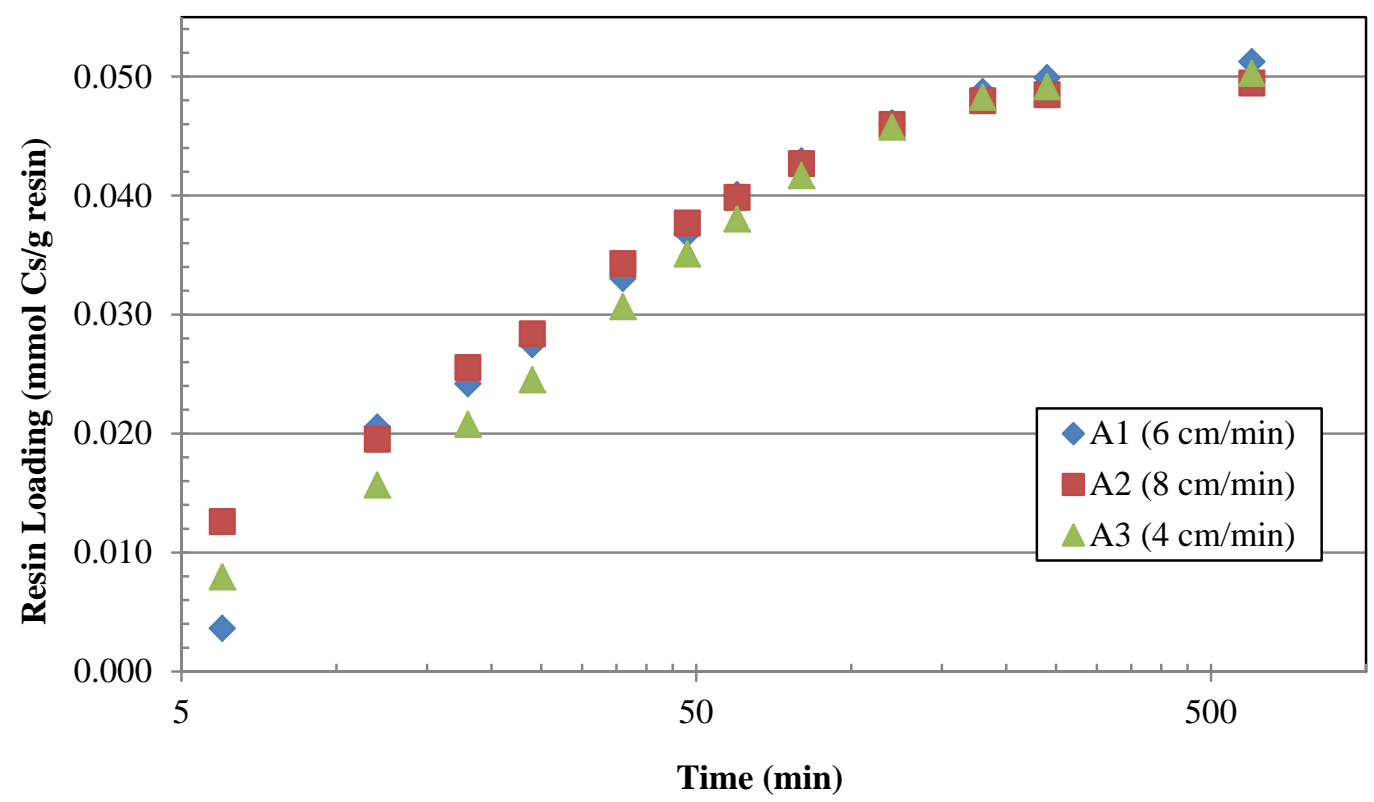

Figure 4.1. Velocity Impact on Kinetics of Column A $\left(45^{\circ} \mathrm{C}\right)$ Cs Loading

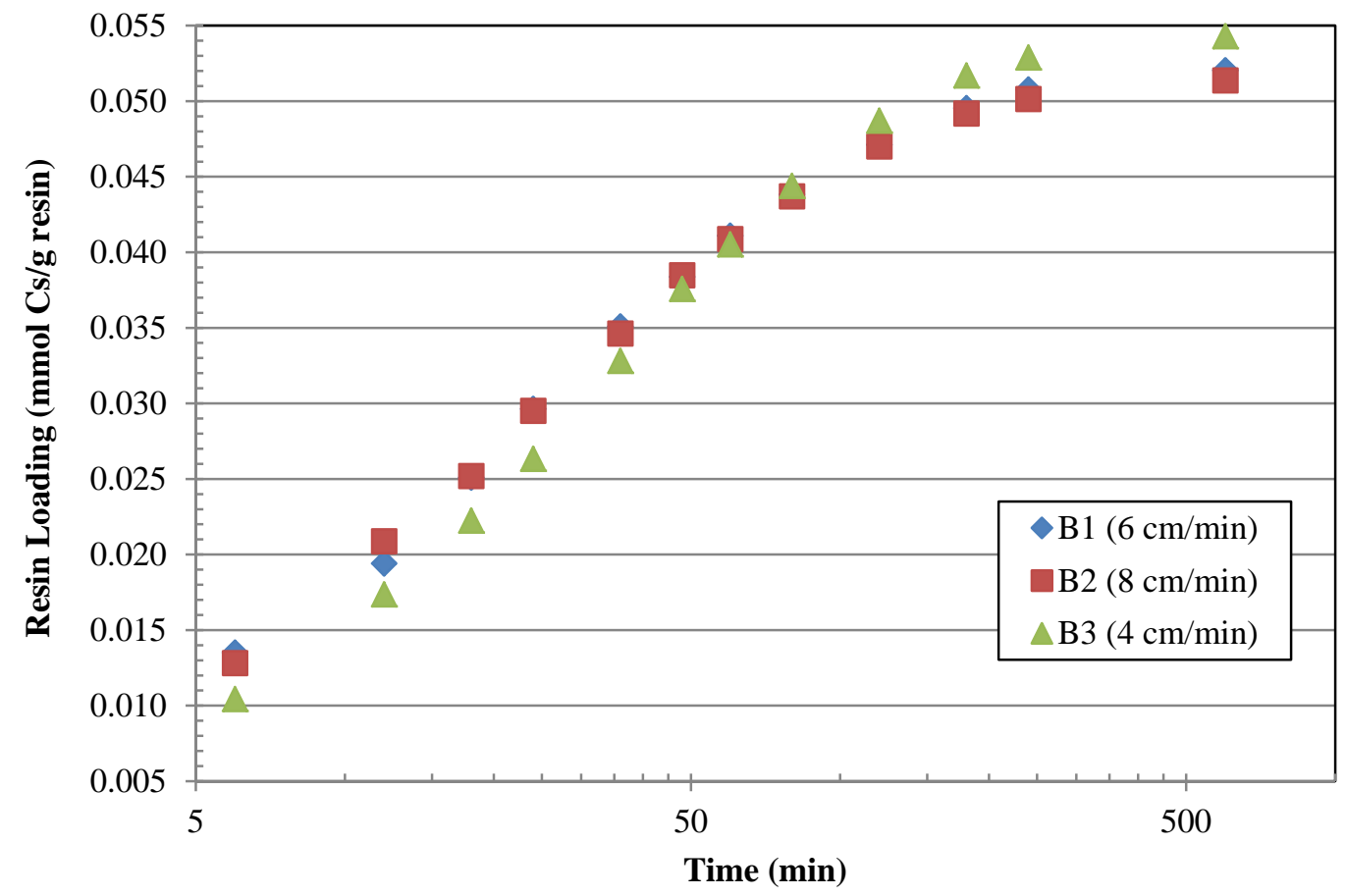

Figure 4.2. Velocity Impact on Kinetics of Column B $\left(40^{\circ} \mathrm{C}\right)$ Cs Loading 


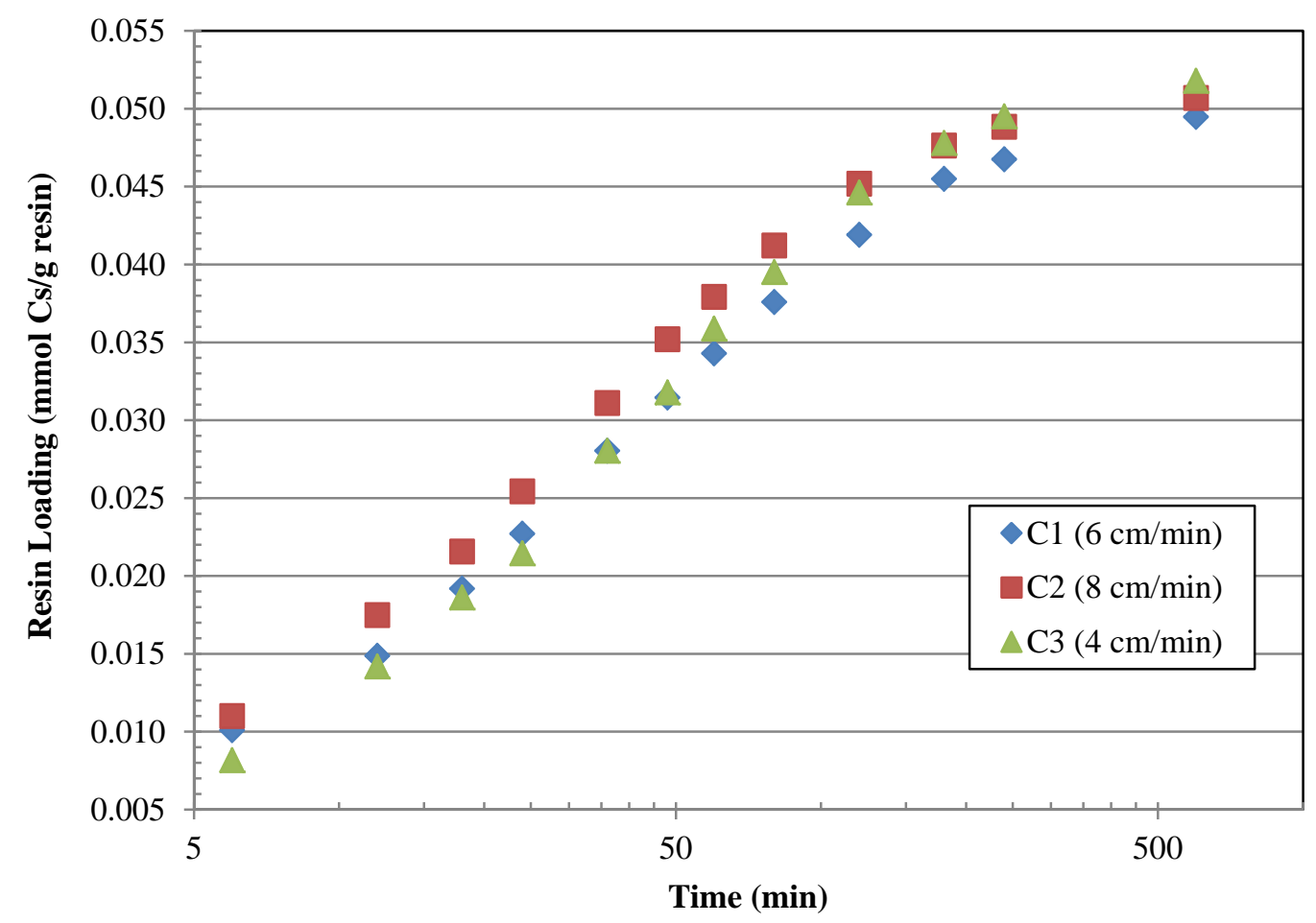

Figure 4.3. Velocity Impact on Kinetics of Column C $\left(30^{\circ} \mathrm{C}\right)$ Cs Loading

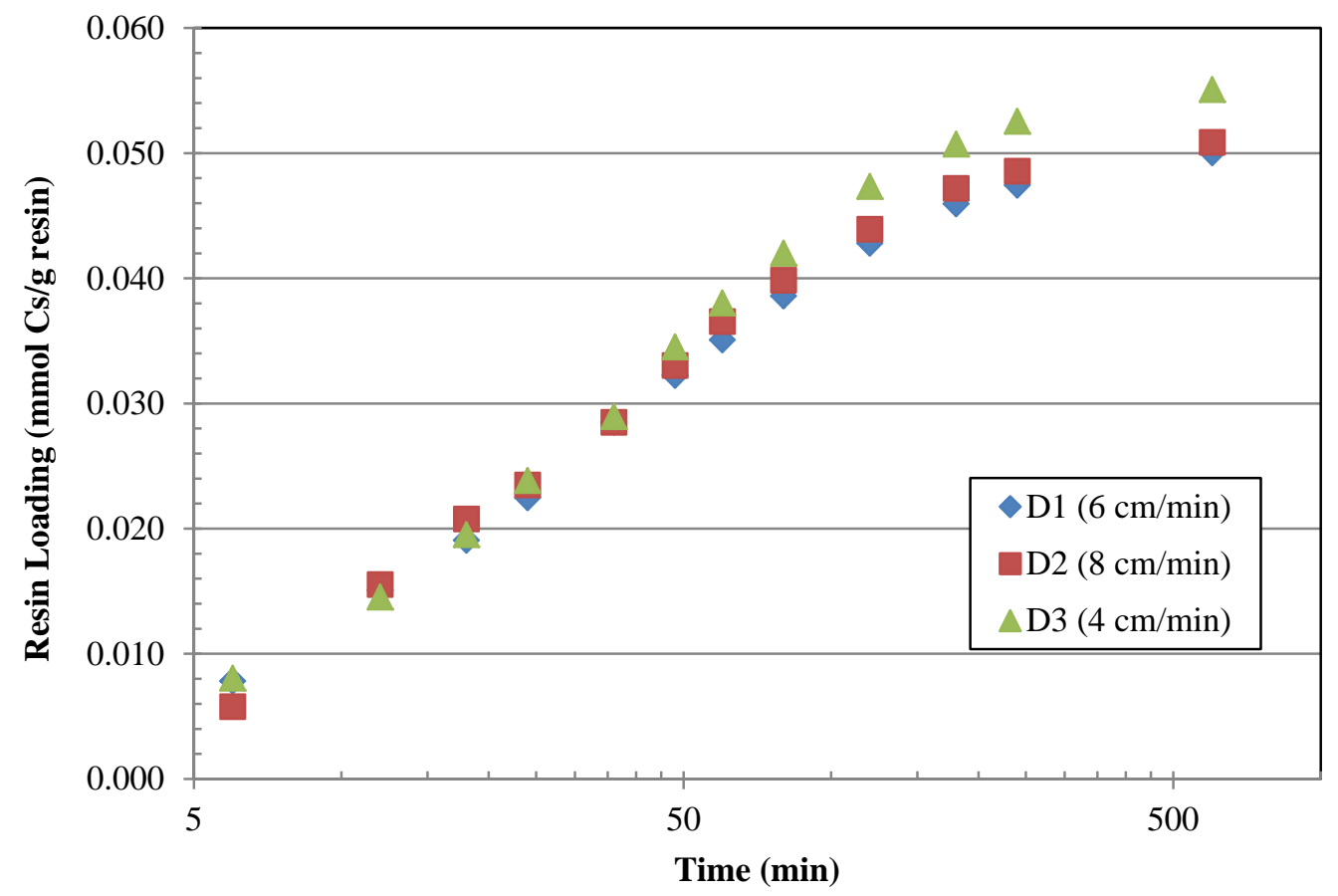

Figure 4.4. Velocity Impact on Kinetics of Column D $\left(25^{\circ} \mathrm{C}\right)$ Cs Loading 


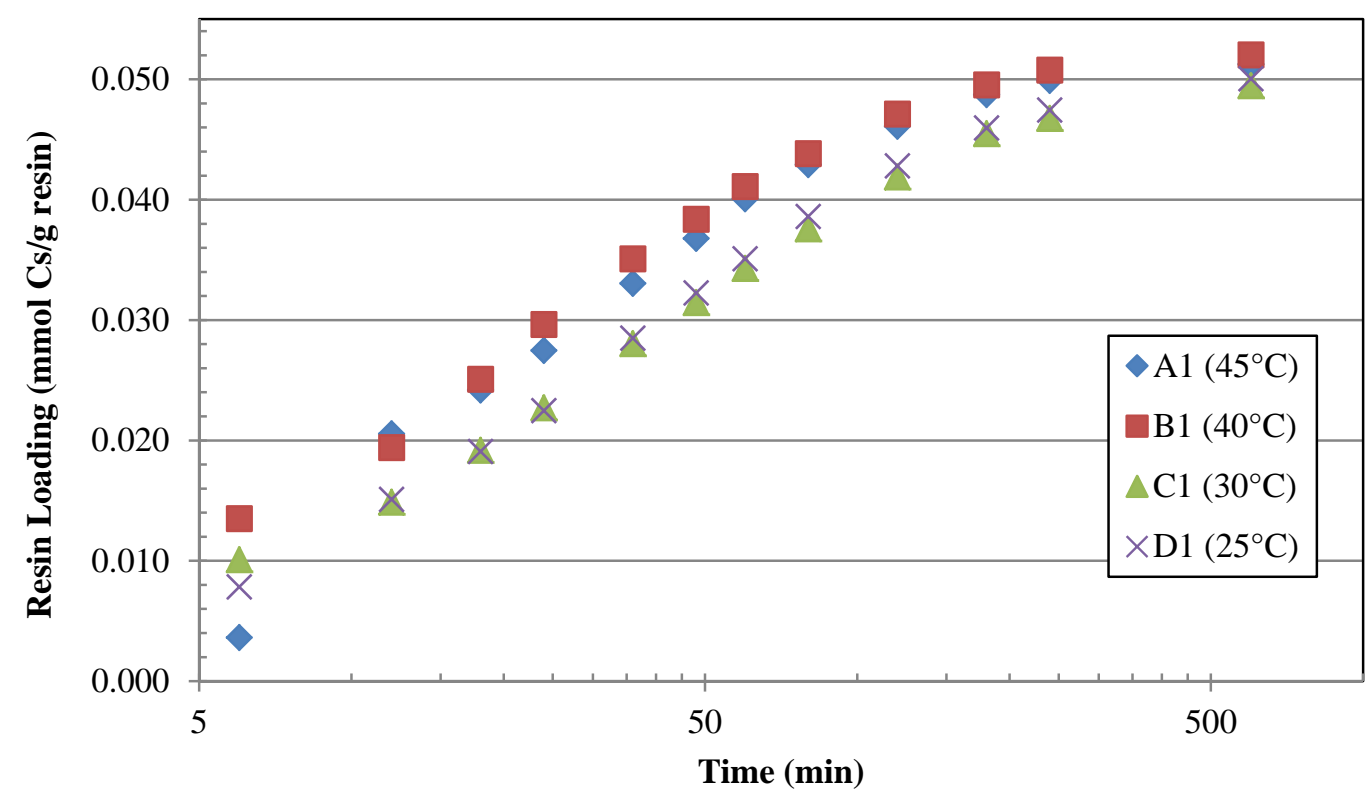

Figure 4.5. Temperature Effect on Cs Loading Kinetics of Test $1(6 \mathrm{~cm} / \mathrm{min})$

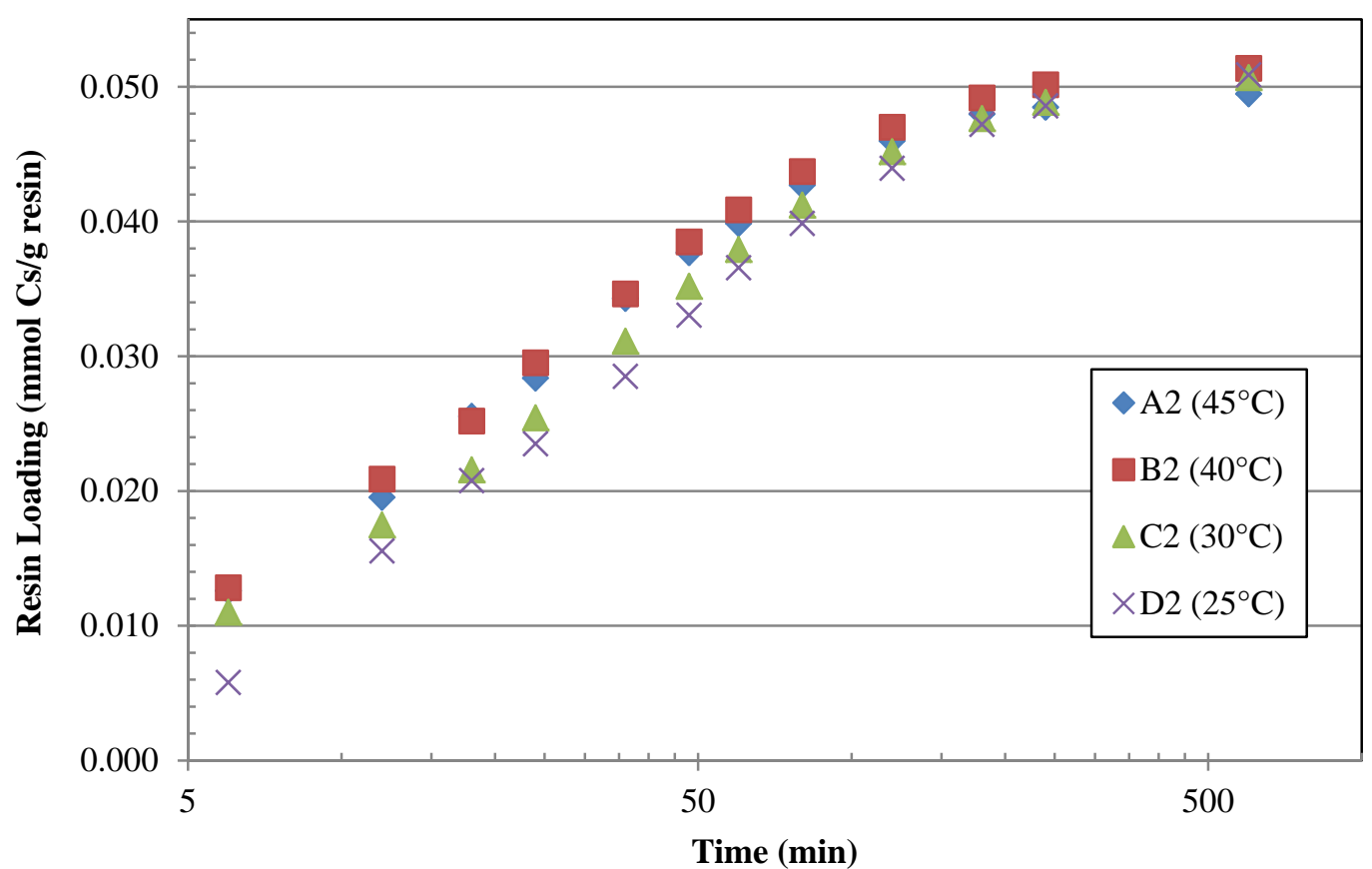

Figure 4.6. Temperature Effect on Cs Loading Kinetics of Test $2(8 \mathrm{~cm} / \mathrm{min})$ 


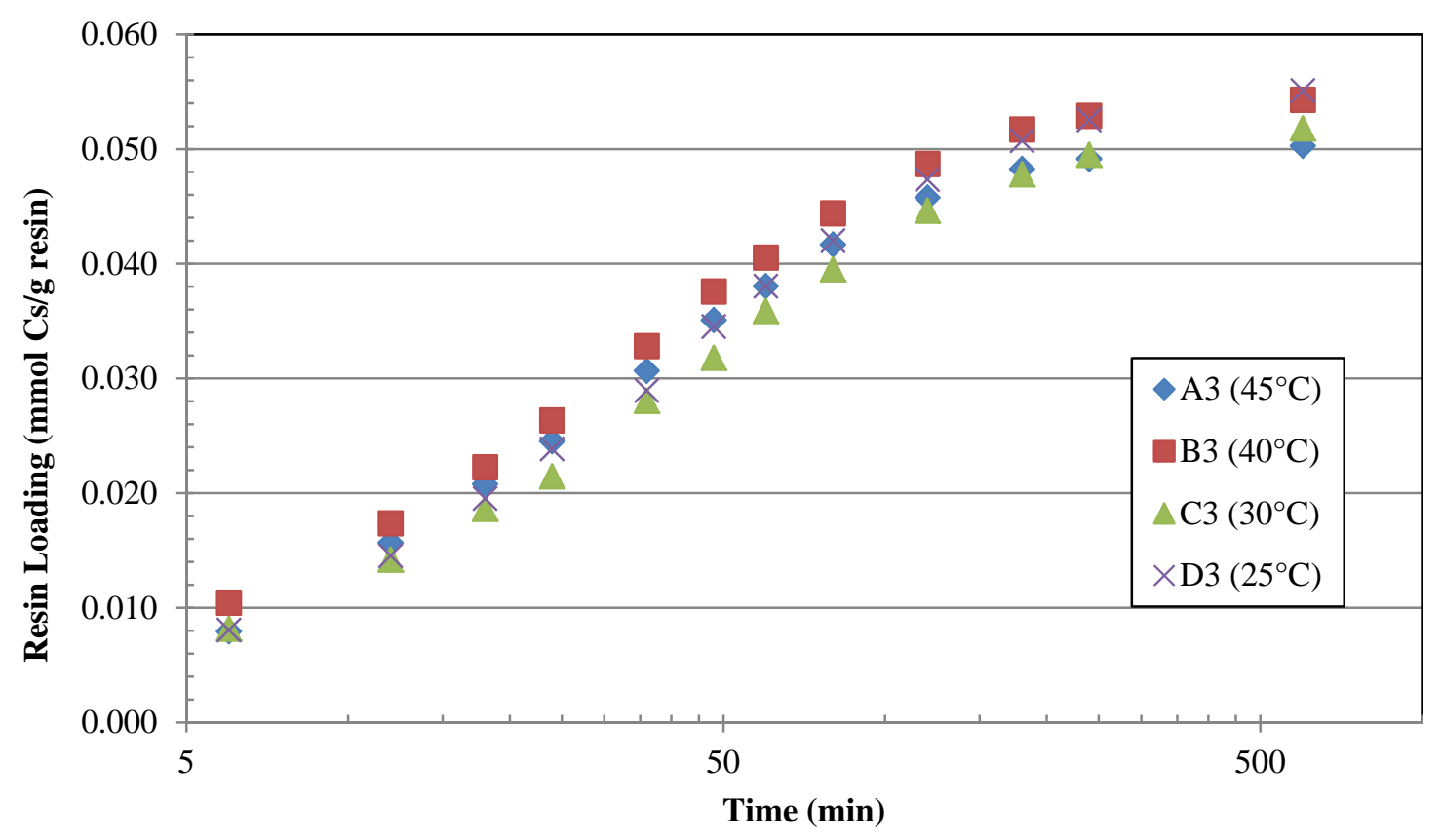

Figure 4.7. Temperature Effect on Kinetics of Test $3(4 \mathrm{~cm} / \mathrm{min})$

\subsection{Impacts of Extended Elevated Temperature on Resin Loading}

Resin was loaded for 336 to $720 \mathrm{hr}$ at several elevated temperatures at a very low linear load velocity ( $\sim 0.08 \mathrm{~cm} / \mathrm{min}$ ) compared to the column tests described in Section 4.1. The linear load velocity was as slow as possible to observe what was happening to the resin when held at higher temperatures for extended times. These tests are designated as $-4 \mathrm{~B}$ in Table 3.4. Samples were taken periodically throughout the test to determine the Cs uptake curve as shown in Figure 4.9. These tests were not scaled to the WTP ion exchange columns but were to just observe the degradation and temperature effect on the ion exchange resin over time.

Testing for these extended times at elevated temperatures showed that the Cs loading decreased at $45^{\circ} \mathrm{C}$ and continually decreased with increasing temperature. At $60^{\circ} \mathrm{C}$, the Cs loading had decreased by 35 percent from the $45^{\circ} \mathrm{C}$ test. All columns, with the exception of the $45^{\circ} \mathrm{C}$ column, plugged prior to $720 \mathrm{hr}$ of testing. The $55^{\circ} \mathrm{C}$ and $60^{\circ} \mathrm{C}$ columns plugged after about 14 days ( $336 \mathrm{hr}$ ) and the $50^{\circ} \mathrm{C}$ column plugged after about 25 days ( $600 \mathrm{hr}$ ). The resin that plugged the columns was found to be hard clumps that were difficult to break apart. These agglomerates effectively inhibited the flow of solution. Two of the columns had to be opened and the resin masses broken up before the columns could be eluted. The overall Cs loading at these temperatures is shown in Figure 4.8. These loading results are in strong agreement with previous work (Russell et al. 2012).

Regardless of temperature, Cs loading peaked after about $72 \mathrm{hr}$ and then began to decrease (see Figure 4.9). However, less of a decrease in Cs loading was observed at lower temperatures (e.g., from 4 percent at $45^{\circ} \mathrm{C}$ to 22 percent at $60^{\circ} \mathrm{C}$ ). Previous work of Cs loading over extended times also showed that the Cs loading peaked after $\sim 72 \mathrm{hr}$ and then began to decrease (Russell et al. 2012). This indicates that the resin loses Cs loading ability over time and with increased temperature, making it unable to hold 
the Cs over a long period of time at elevated temperatures. These results could be significant if the WTP is operating at elevated temperatures and indicate that resin may have to be eluted more often and/or Cs may be lost into the effluent off the column.

In addition, during the $720 \mathrm{hr}$ loading tests, a white precipitate formed on the top and bottom edge of the resin column. It was also noticed that during the tests, and especially during the feed displacement portion of the test, the solution coming out of the column had turned a yellow color after having entered the column completely clear. This is shown in Figure 4.10. This indicates the presence of chemical resin degradation, which explains the lower Cs loading.

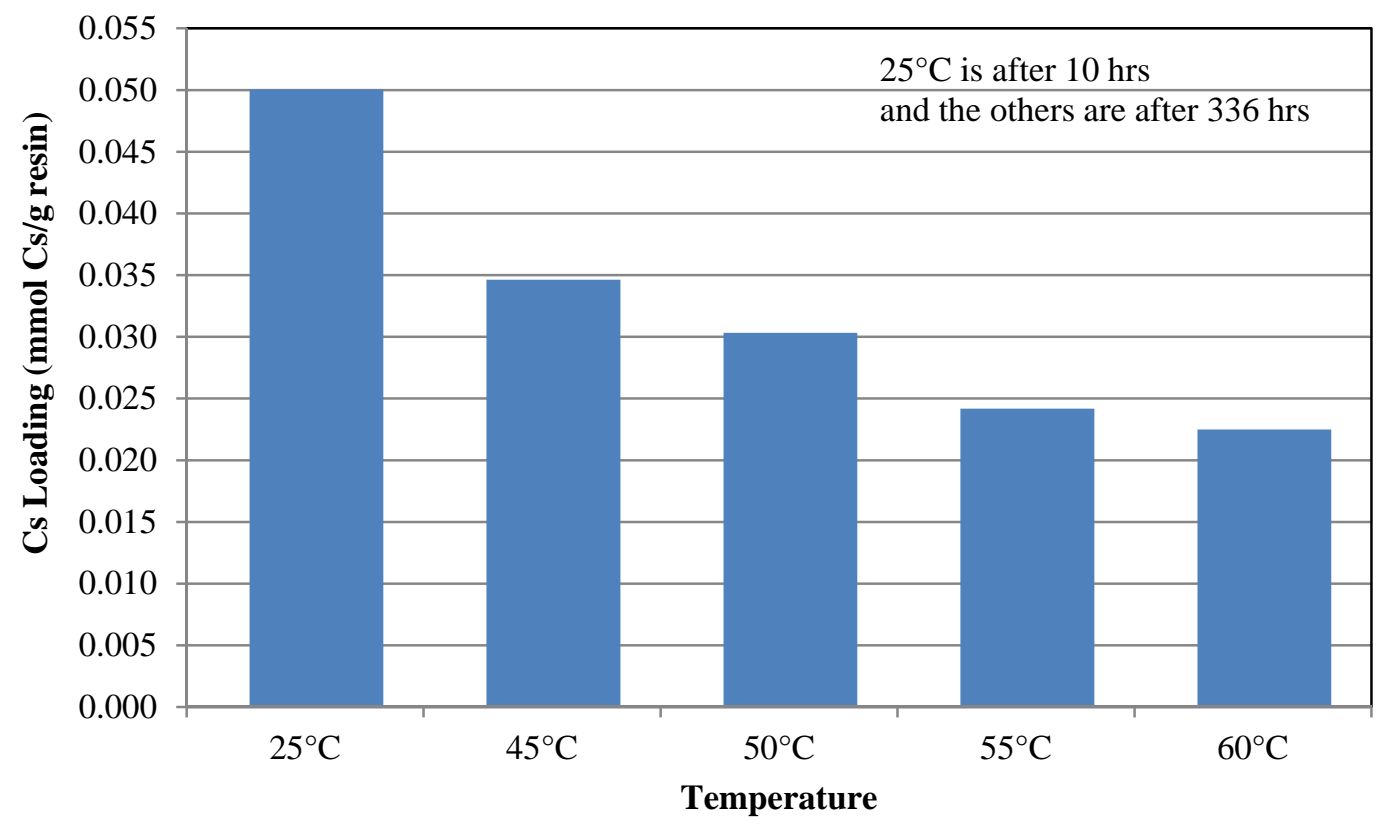

Figure 4.8. Resin Total Cs Loading After Extended Flow Testing 


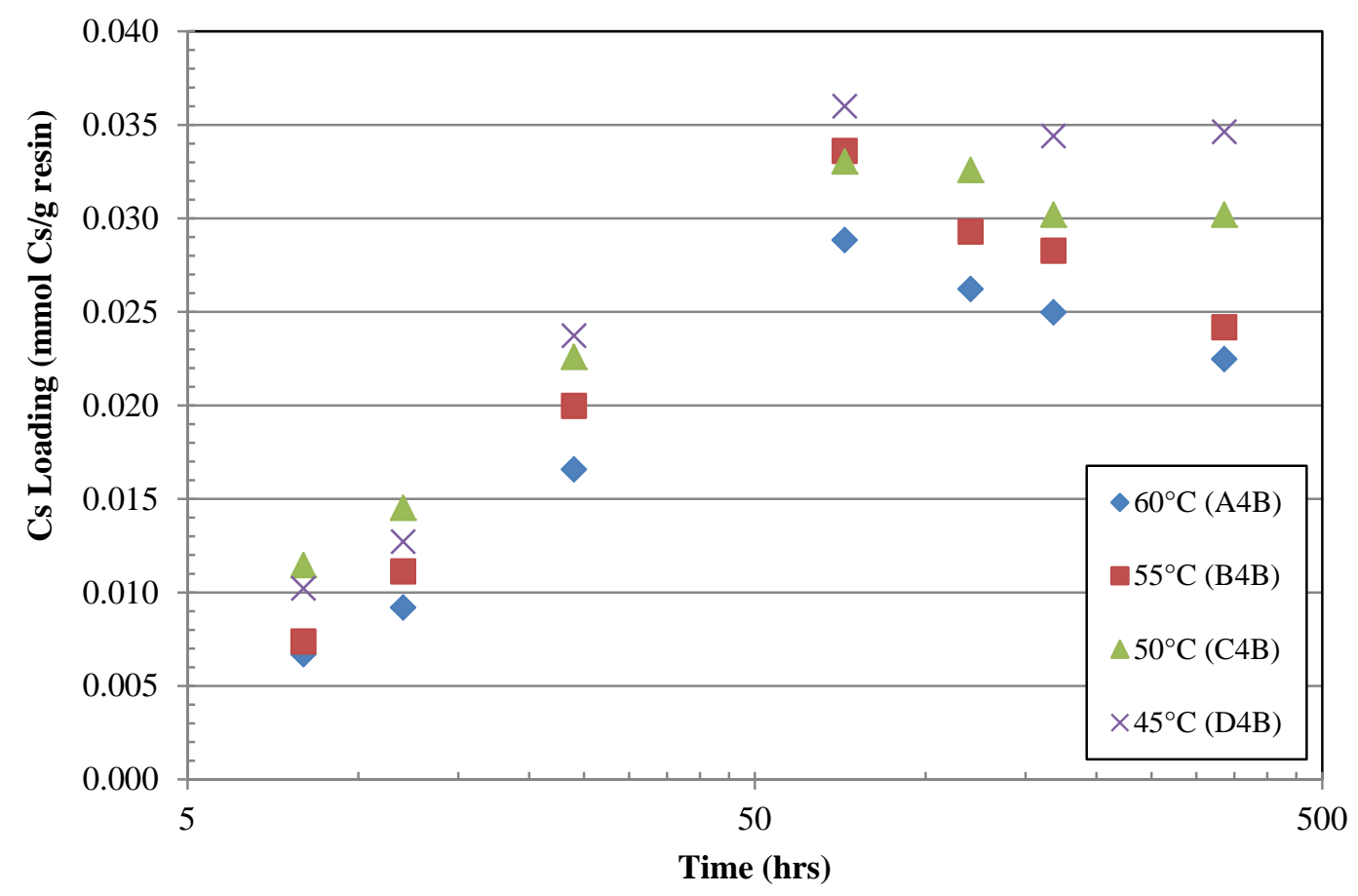

Figure 4.9. Resin Cs Loading During Extended Flow Testing

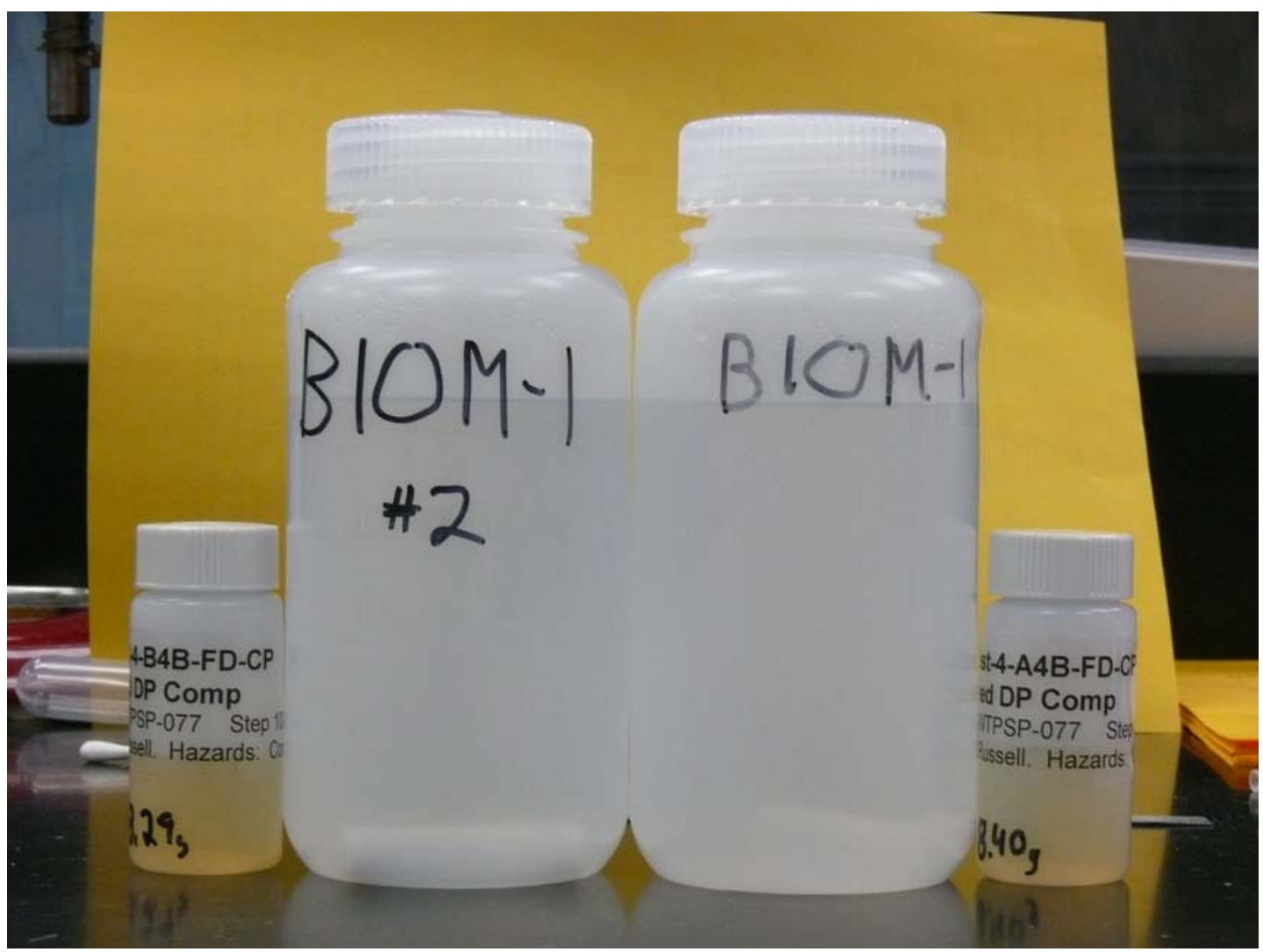

Figure 4.10. Feed Displacement Solution Compared Before and After Running Through the Column 
After the elevated temperature extended flow testing, the resin was loaded again for $10 \mathrm{hr}$ under the same conditions as the initial cycle. This was the last test of each series (-5), shown in Table 3.4, and was used to determine the change in resin Cs loading kinetics and/or Cs uptake after being cycled several times and held at a higher temperature. At cycles kept at $55^{\circ} \mathrm{C}$ and $60^{\circ} \mathrm{C}$, no significant decrease in resin Cs loading (4 percent and 7.5 percent, respectively) was observed and kinetics were essentially the same, as shown in Figure 4.11 and Figure 4.12. However, for the cycles kept at $50^{\circ} \mathrm{C}$ and $45^{\circ} \mathrm{C}$, a decrease in Cs loading kinetics was observed but not in Cs loading (9 percent for $50^{\circ} \mathrm{C}$ and 3.5 percent for $45^{\circ} \mathrm{C}$ ) as shown in Figure 4.13 and Figure 4.14. This may be due to higher temperature increasing kinetics and cancelling the effect of the resin degradation, which results in essentially the same kinetics. At lower temperatures, the resin degradation is evident in the kinetics because the temperature effect is not present. However, the resin does degrade and shows decreased Cs loading after being held at elevated temperatures for extended periods of time. These results could be significant to WTP operations at elevated temperatures as they indicate that resin would need to be exchanged more often. The resin degradation and column plugging observed in the tests conducted above $45^{\circ} \mathrm{C}$ suggest that the maximum operating temperature should be less than $45^{\circ} \mathrm{C}$.

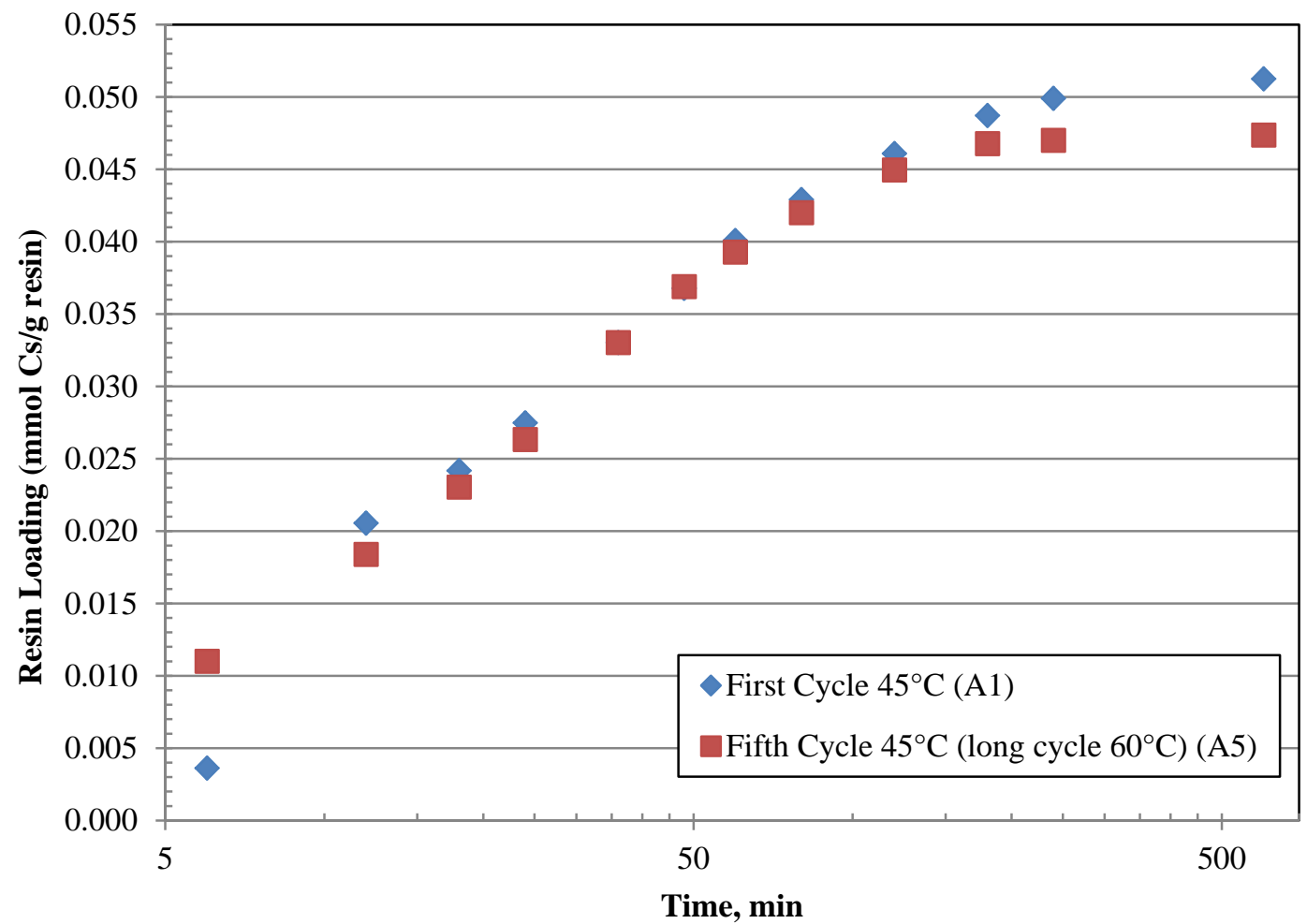

Figure 4.11. First and Fifth Resin Loading Cycles Compared at $45^{\circ} \mathrm{C}$ with Long Loading Cycle at $60^{\circ} \mathrm{C}$ 


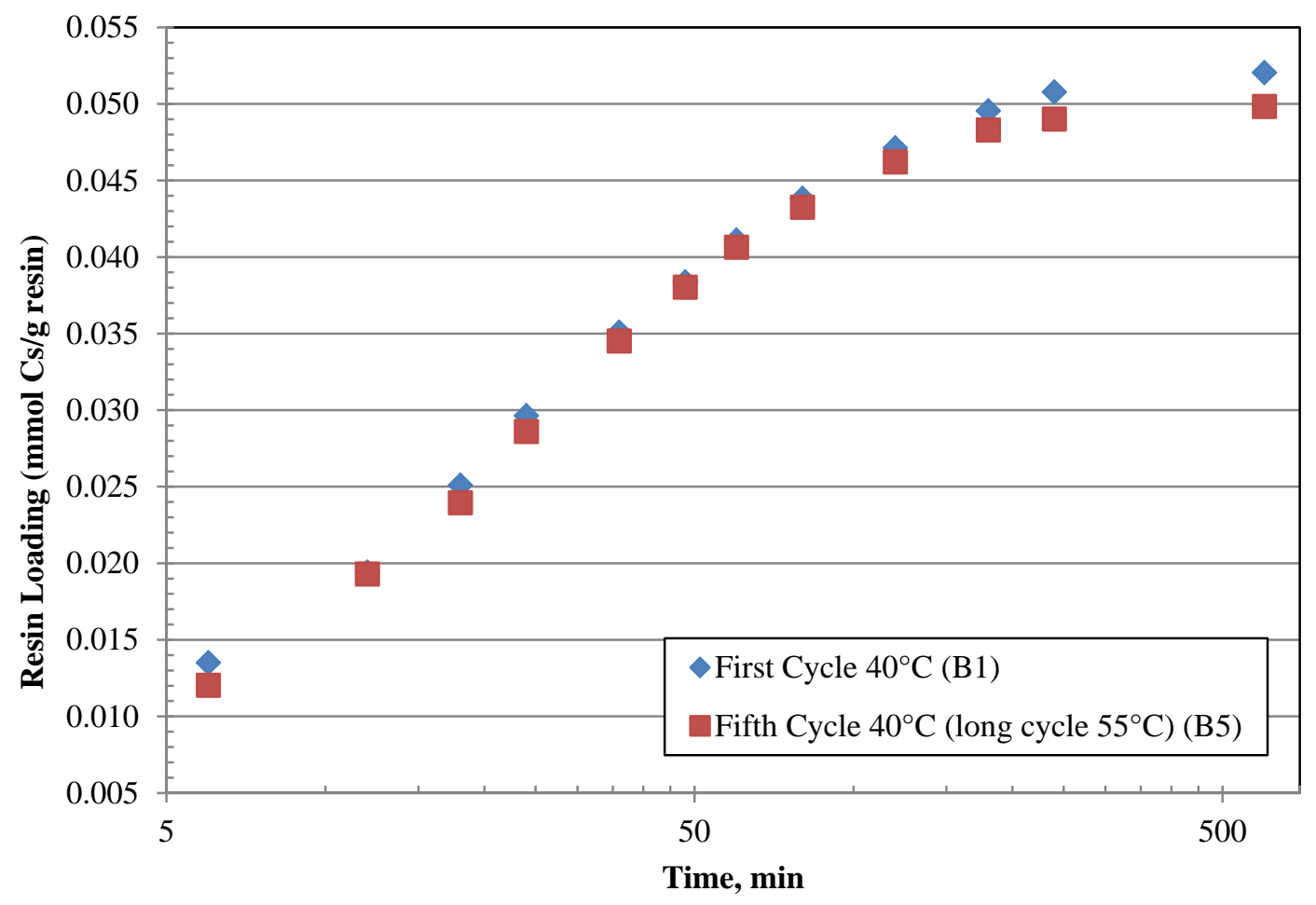

Figure 4.12. First and Fifth Resin Loading Cycles Compared at $40^{\circ} \mathrm{C}$ with Long Loading Cycle at $55^{\circ} \mathrm{C}$

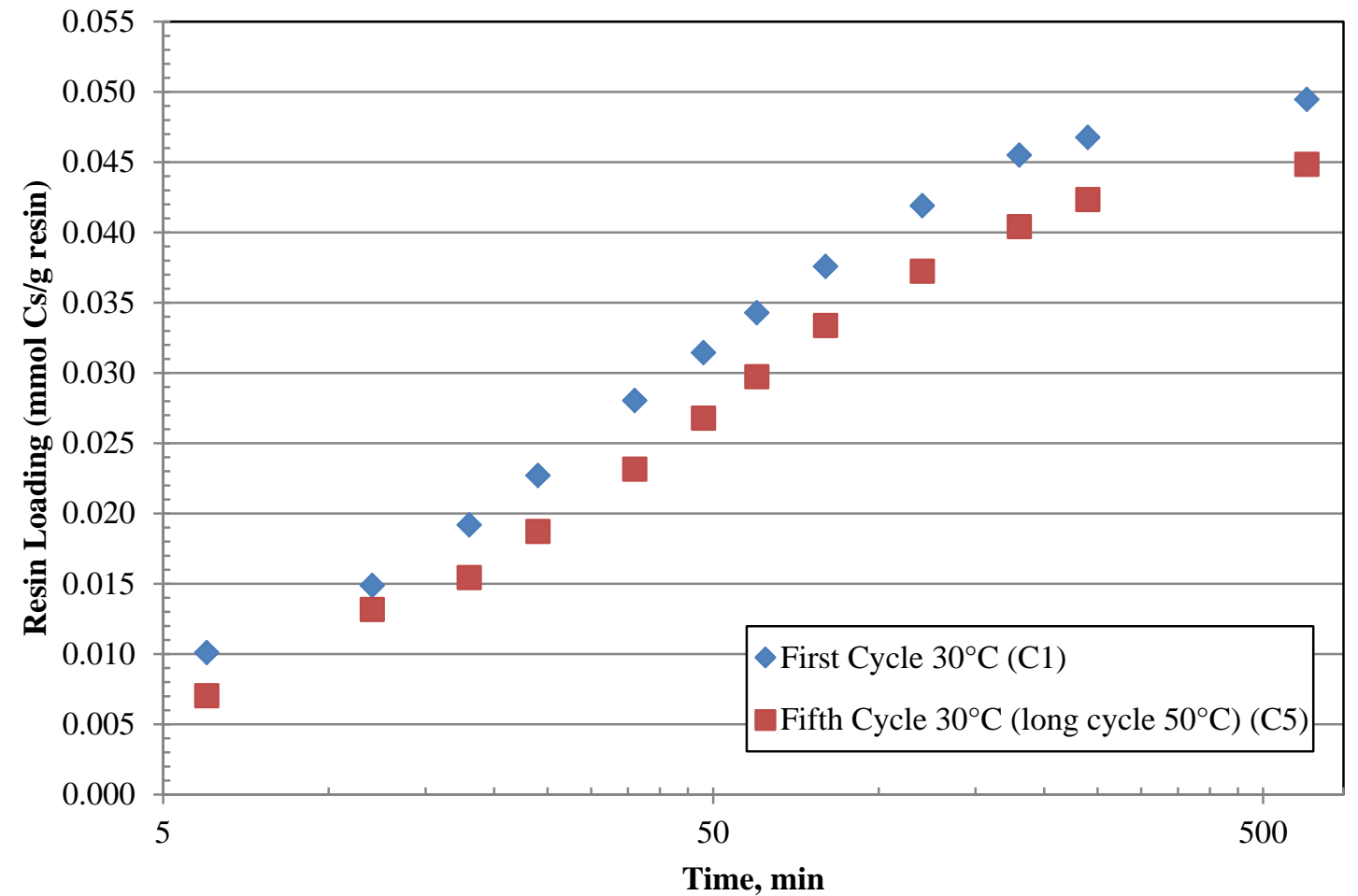

Figure 4.13. First and Fifth Resin Loading Cycles Compared at $30^{\circ} \mathrm{C}$ with Long Loading Cycle at $50^{\circ} \mathrm{C}$ 


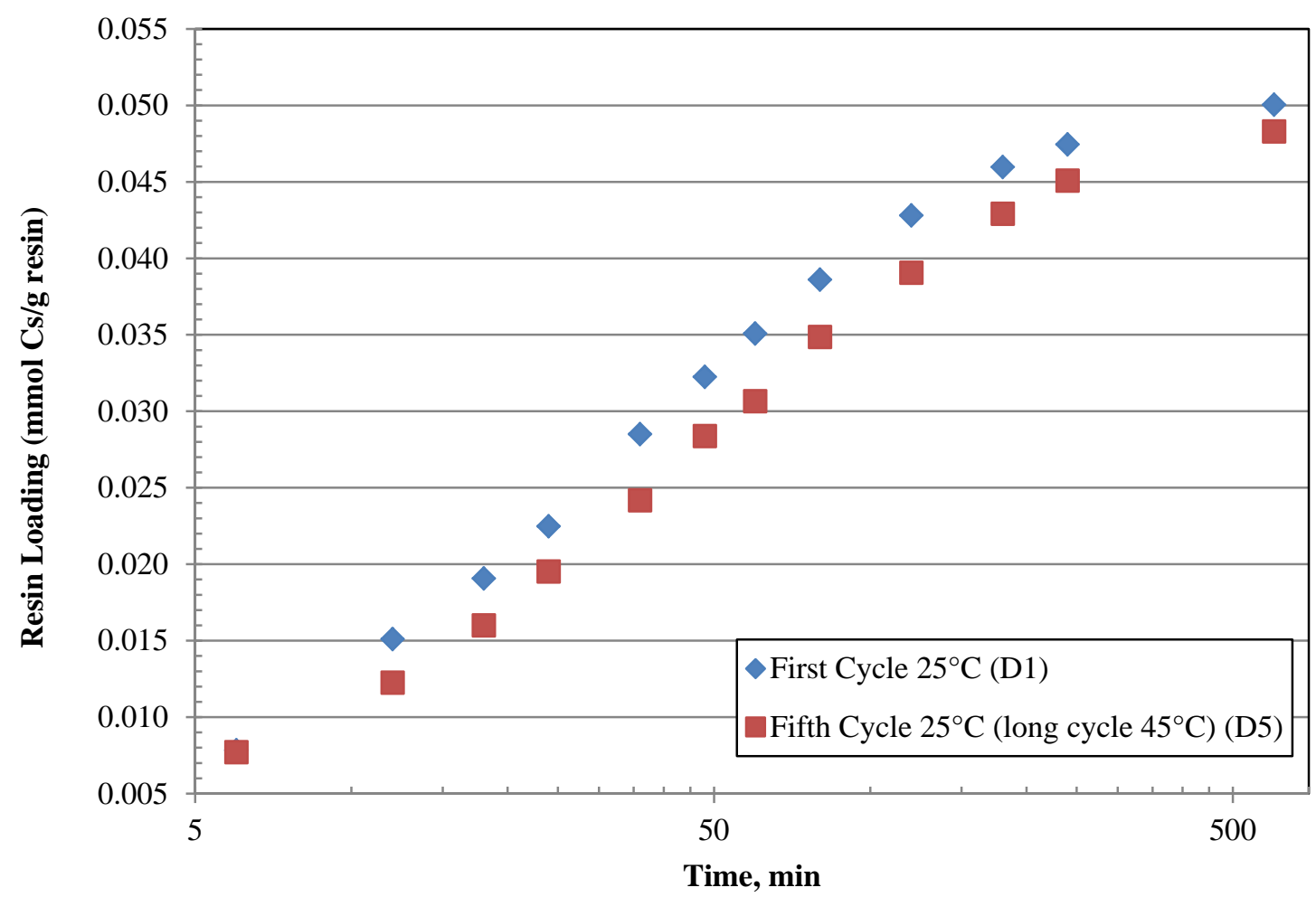

Figure 4.14. First and Fifth Resin Loading Cycles Compared at $25^{\circ} \mathrm{C}$ with Long Loading Cycle at $45^{\circ} \mathrm{C}$

When testing was completed, the columns were dismantled and observed for resin degradation and precipitates. An unidentified flaky translucent precipitate was observed on the resin. However, no substantial physical degradation of the resin was observed. The new and used resin was examined under a microscope for comparison (Figure 4.15) and average particle size was measured (Table 4.1). No significant particle size reduction was observed with all results being within experimental error, which indicates that physical degradation of the resin did not occur or occurred in a very slight manner over this testing period.

Table 4.1. Average Particle Size of Resin Both Before and After Use

\begin{tabular}{lcc}
\hline & Average $(\mathrm{mm})$ & Std Dev $(\mathrm{mm})$ \\
\hline New $\mathrm{Na}^{+}$SRF Resin & 0.400 & 0.024 \\
New $\mathrm{H}^{+}$SRF Resin & 0.373 & 0.004 \\
Column A Used $\left(45^{\circ} \mathrm{C}\right.$ and $\left.60^{\circ} \mathrm{C}\right)$ & 0.383 & 0.027 \\
Column B Used $\left(40^{\circ} \mathrm{C}\right.$ and $\left.55^{\circ} \mathrm{C}\right)$ & 0.380 & 0.042 \\
Column C Used $\left(30^{\circ} \mathrm{C}\right.$ and $\left.50^{\circ} \mathrm{C}\right)$ & 0.382 & 0.031 \\
Column D Used $\left(25^{\circ} \mathrm{C}\right.$ and $\left.45^{\circ} \mathrm{C}\right)$ & 0.372 & 0.012 \\
\hline
\end{tabular}




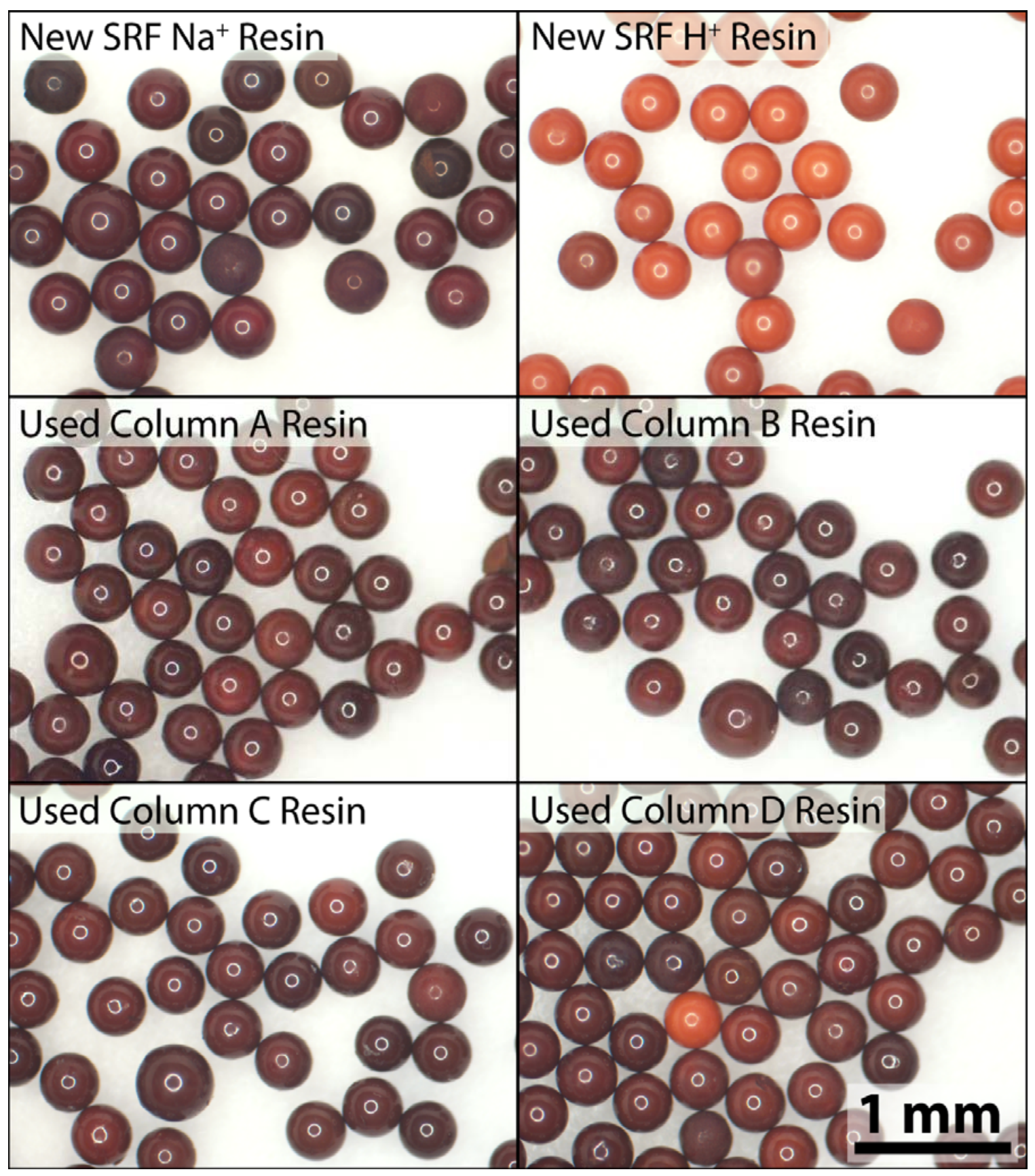

Figure 4.15. Microscopic Comparison of Resin from All Tests (circles are light reflections)

\subsection{Batch Loading Test Results}

The effect of the initial Na concentration $(0.1,0.5,0.75,1,3,5 \underline{\mathrm{M}})$, initial K concentration $(0.005$ and $0.05 \underline{\mathrm{M}})$, and initial $\mathrm{OH}$ concentration $(0.1$ and $1 \underline{\mathrm{M}})$ on the resin's Cs loading at temperatures of $25^{\circ} \mathrm{C}$, $35^{\circ} \mathrm{C}$, and $50^{\circ} \mathrm{C}$ was tested using batch tests. The results of this research are discussed in this section. 


\subsubsection{Na Effect on Resin Cs Loading}

Figure 4.16 presents the effect of different Na levels on resin Cs loading at $50^{\circ} \mathrm{C}$ with $\mathrm{K}$ and $\mathrm{OH}$ concentrations of 0.005 and $0.1 \underline{\mathrm{M}}$, respectively. Clearly, Na has a significant effect on the Cs loading, with the more Na present the less Cs loaded. Previous work also observed this effect (Nash et al. 2006 and Russell et al. 2012). The $0.1 \underline{\mathrm{M}}$ Na shows the highest Cs loading at all concentrations and $5 \underline{\mathrm{M}} \mathrm{Na}$ shows the lowest Cs loading. However, not much difference in Cs loading is seen between 0.5 and $1 \underline{\mathrm{M}} \mathrm{Na}$. The greater effect seen between the 3 and $1 \underline{\mathrm{M}} \mathrm{Na}$ and the $3 \underline{\mathrm{M}} \mathrm{Na}$ and $5 \underline{\mathrm{M}} \mathrm{Na}$ is expected because the Na concentration is orders of magnitude higher than the Cs concentration in the feed and therefore takes the resin loading sites more easily. Lower Na concentration allows Cs to compete for the resin sites more effectively. The same effects were seen at $25^{\circ} \mathrm{C}$ (Figure 4.17). Therefore, the lower the Na level that the PTF processes, the better Cs loading the WTP should obtain on the SRF resin.

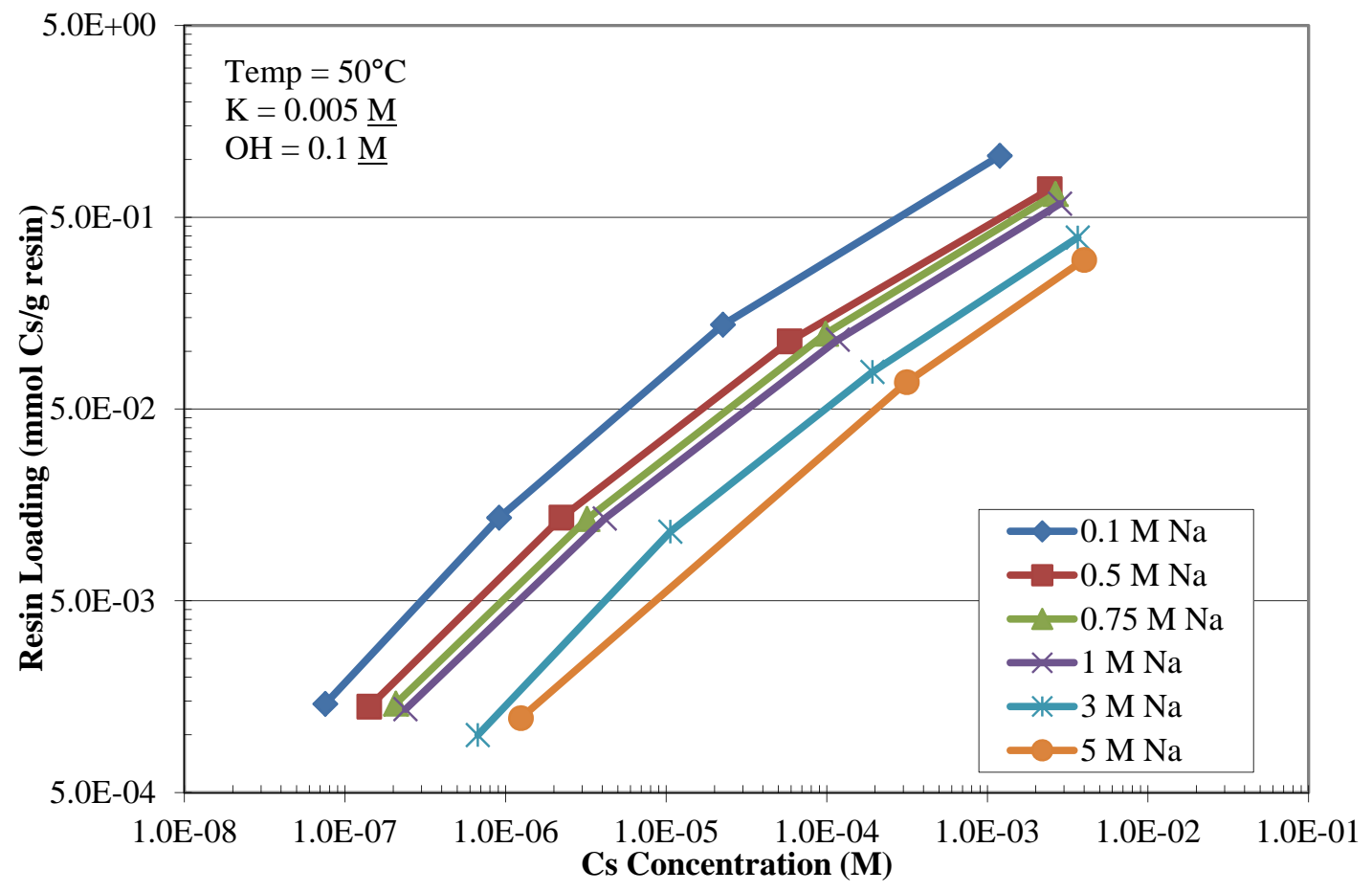

Figure 4.16. Na Effect on Cs Loading at $50^{\circ} \mathrm{C}, 0.005 \underline{\mathrm{M}} \mathrm{K}$, and $0.1 \underline{\mathrm{M}} \mathrm{OH}$ 


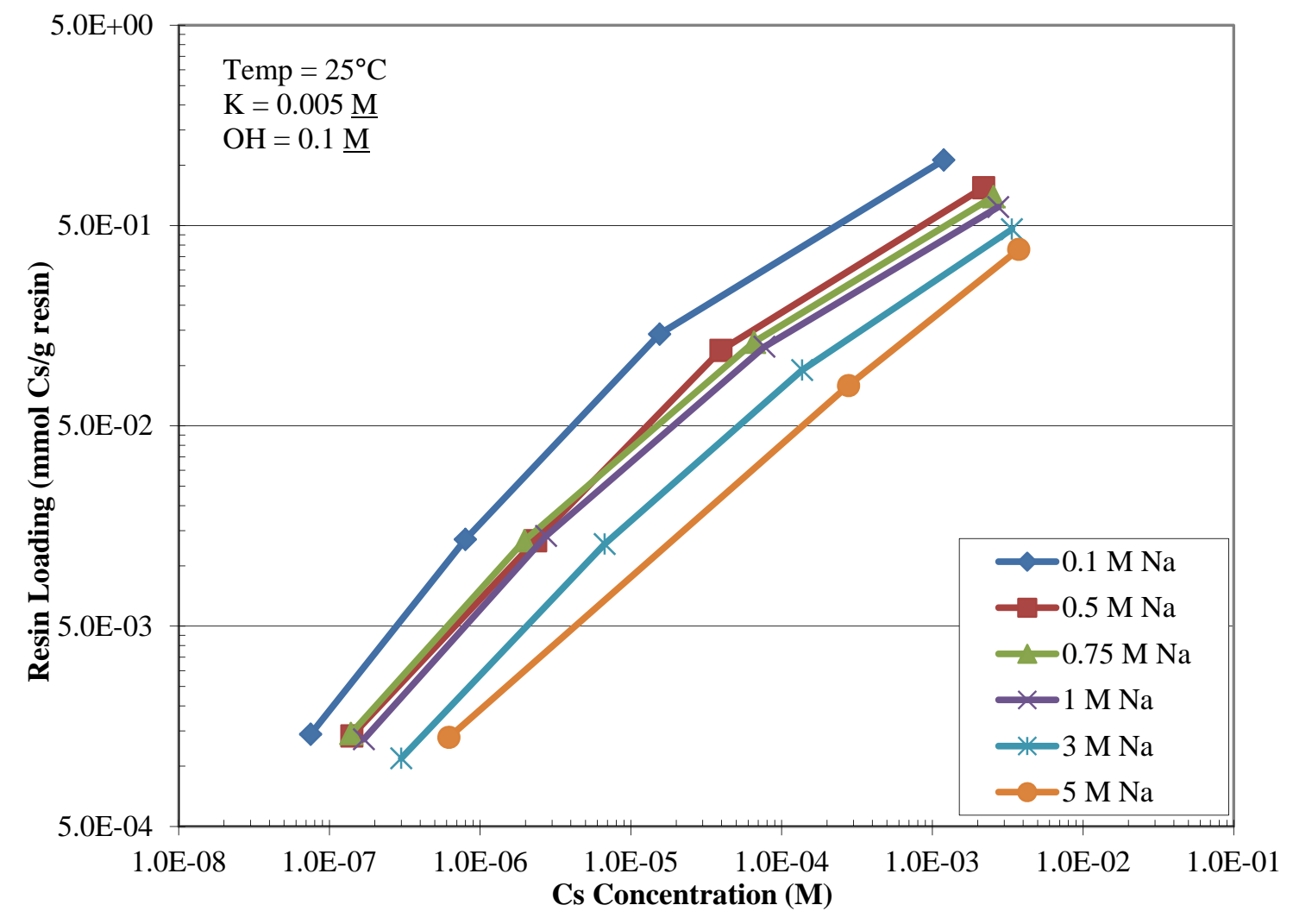

Figure 4.17. Na Effect on Cs Loading at $25^{\circ} \mathrm{C}, 0.005 \underline{\mathrm{M}} \mathrm{K}$, and $0.1 \underline{\mathrm{M}} \mathrm{OH}$

\subsubsection{K Effect on Resin Cs Loading}

Figure 4.18 presents the effect of different $\mathrm{K}$ levels on resin Cs loading at $50^{\circ} \mathrm{C}$ with a $1 \underline{\mathrm{M}} \mathrm{OH}$ concentration and 1 and $5 \underline{\mathrm{M}}$ Na concentrations. The effect of K on Cs loading appears to vary. Lower Cs concentrations yielded greater $\mathrm{K}$ effect, which was expected due to competition for the resin sites between $\mathrm{K}$ and Cs. Higher Cs concentrations were less affected by K. At the highest Cs concentration tested $(0.001 \underline{\mathrm{M}})$, no significant $\mathrm{K}$ effect was observed. This could be due to the fact that as more Cs is present, there is a greater competition for the resin sites between the Cs and $\mathrm{K}$. The affinity of the resin is higher for Cs than for K, causing it to load essentially the same amount of Cs with or without the K. Previous studies also noted this trend and observed that above a Cs concentration of $0.001 \underline{\mathrm{M}}$, the Cs adsorption was more favorable at higher K concentration (Nash and Isom 2010). Higher concentrations of Cs were not tested here in order to confirm this observation because Hanford waste does not contain those levels of Cs. The effect of the $\mathrm{K}$ is also greater at the $1 \underline{\mathrm{M}} \mathrm{Na}$ than at the $5 \underline{\mathrm{M}} \mathrm{Na}$ indicating again that at higher Na concentrations, $\mathrm{Na}$ takes the resin sites regardless of $\mathrm{K}$ concentration.

The effect of $\mathrm{K}$ concentration on Cs resin loading at $25^{\circ} \mathrm{C}$ with $5 \mathrm{M}$ Na appears negligible regardless of Cs concentration (Figure 4.19). However, at $1 \underline{\mathrm{M}} \mathrm{Na}$, the effect of $\mathrm{K}$ becomes greater with Cs loading decreasing with Cs concentration to about the same level as $5 \underline{\mathrm{M}} \mathrm{Na}$ at the lowest Cs concentration. 
At $0.1 \mathrm{M} \mathrm{Na}$, the K effect is greatly increased especially, at lower Cs concentrations, with Cs loading at both 50 and $25^{\circ} \mathrm{C}$ reduced by about 40 percent as shown in Figure 4.20 and Figure 4.21. This is due to less $\mathrm{Na}$ competing for resin sites and $\mathrm{K}$ being the dominant ion.

Again, the K effect varies depending on Cs and Na concentrations. The K concentration has a greater effect at both lower Cs and Na levels. At $3 \underline{\mathrm{M}} \mathrm{Na}$ and $0.001 \underline{\mathrm{M}} \mathrm{Cs}$, the K effect is negligible. Bray et al. (1996) reported similar results using ground gel RF and neutralized current acid waste. At $0.003 \underline{\mathrm{M}} \mathrm{Cs}$ with $3 \underline{\mathrm{M}}$ Na solution, $\mathrm{K}$ competition appeared to vanish. At $0.1 \underline{\mathrm{M}} \mathrm{Na}$ and low Cs concentration, $\mathrm{K}$ lowered the Cs loading level to less than that of $1 \underline{\mathrm{M}} \mathrm{Na}$, without the high $\mathrm{K}$ levels.

\subsubsection{OH Effect on Resin Cs Loading Capacity}

Figure 4.22 through Figure 4.23 show that the effect of different $\mathrm{OH}$ levels on Cs loading is not significant at the levels tested. OH concentration appears to have a slightly positive effect at higher Cs and lower Na concentrations. The presence of $\mathrm{OH}$ helps de-protonize the resin, opening up exchange sites and allowing the Cs ions to load more easily. Therefore, at higher Cs concentrations, more $\mathrm{OH}$ will be needed to form the ionic sites on the resin to accept the Cs. If not enough $\mathrm{OH}$ is present to form these sites, Cs loading decreases. This effect was also observed in Nash et al. (2006) and Nash and Isom (2010). These results indicate that the presence of OH in the WTP feed may slightly help resin Cs loading at higher Cs concentrations, but probably will not make a notable difference, especially in the presence of high $\mathrm{Na}$ and $\mathrm{K}$ concentrations where this effect is decreased.

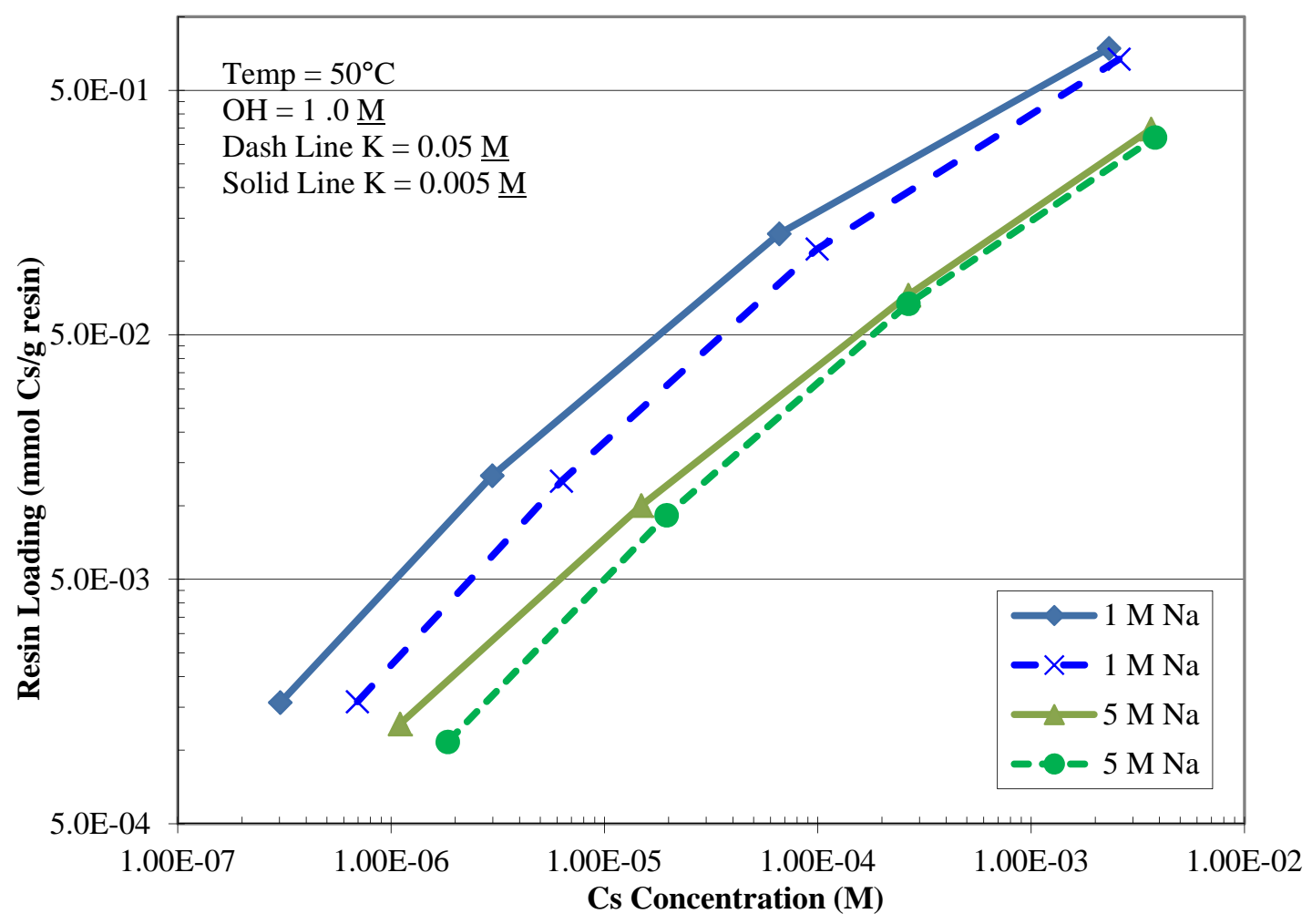

Figure 4.18. K Effect on Cs Loading at $50^{\circ} \mathrm{C}, 1$ and $5 \underline{\mathrm{M}} \mathrm{Na}$, and $1.0 \underline{\mathrm{M}} \mathrm{OH}$ 


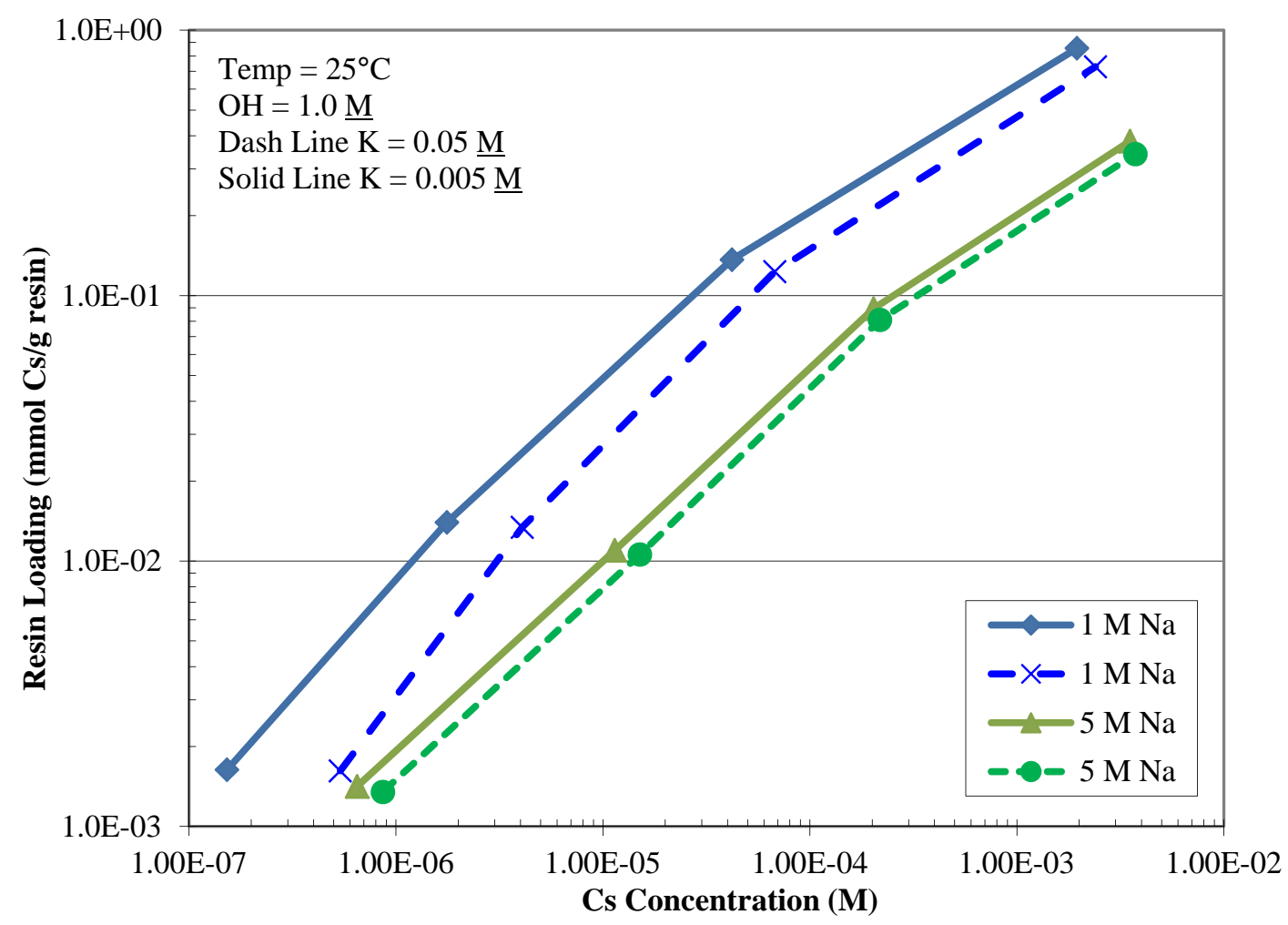

Figure 4.19. K Effect on Cs Loading at $25^{\circ} \mathrm{C}, 1$ and $5 \underline{\mathrm{M}} \mathrm{Na}$, and $1.0 \underline{\mathrm{M}} \mathrm{OH}$

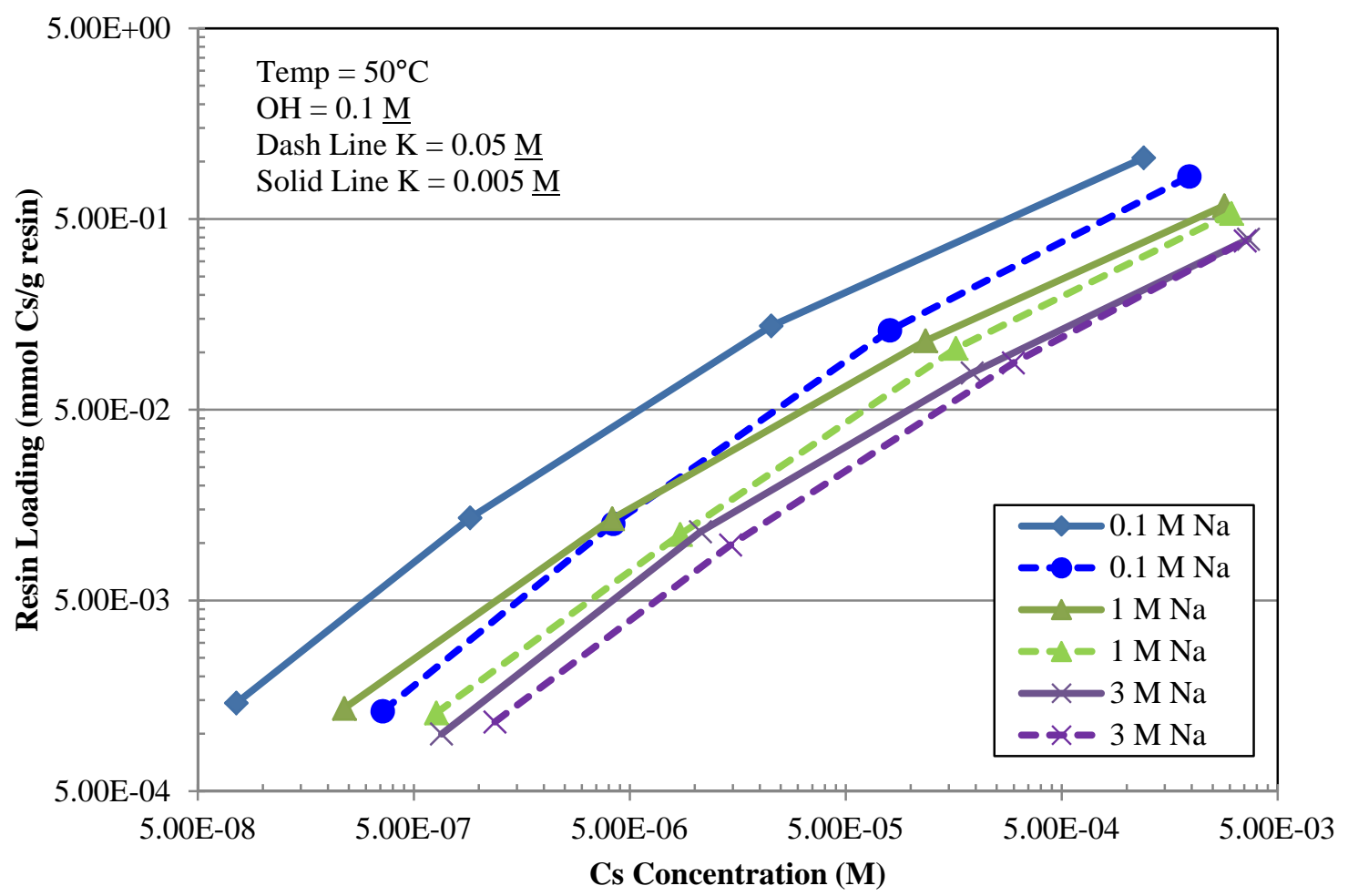

Figure 4.20. K Effect on Cs Loading at $50^{\circ} \mathrm{C}$ and $0.1 \underline{\mathrm{M}} \mathrm{OH}$ 


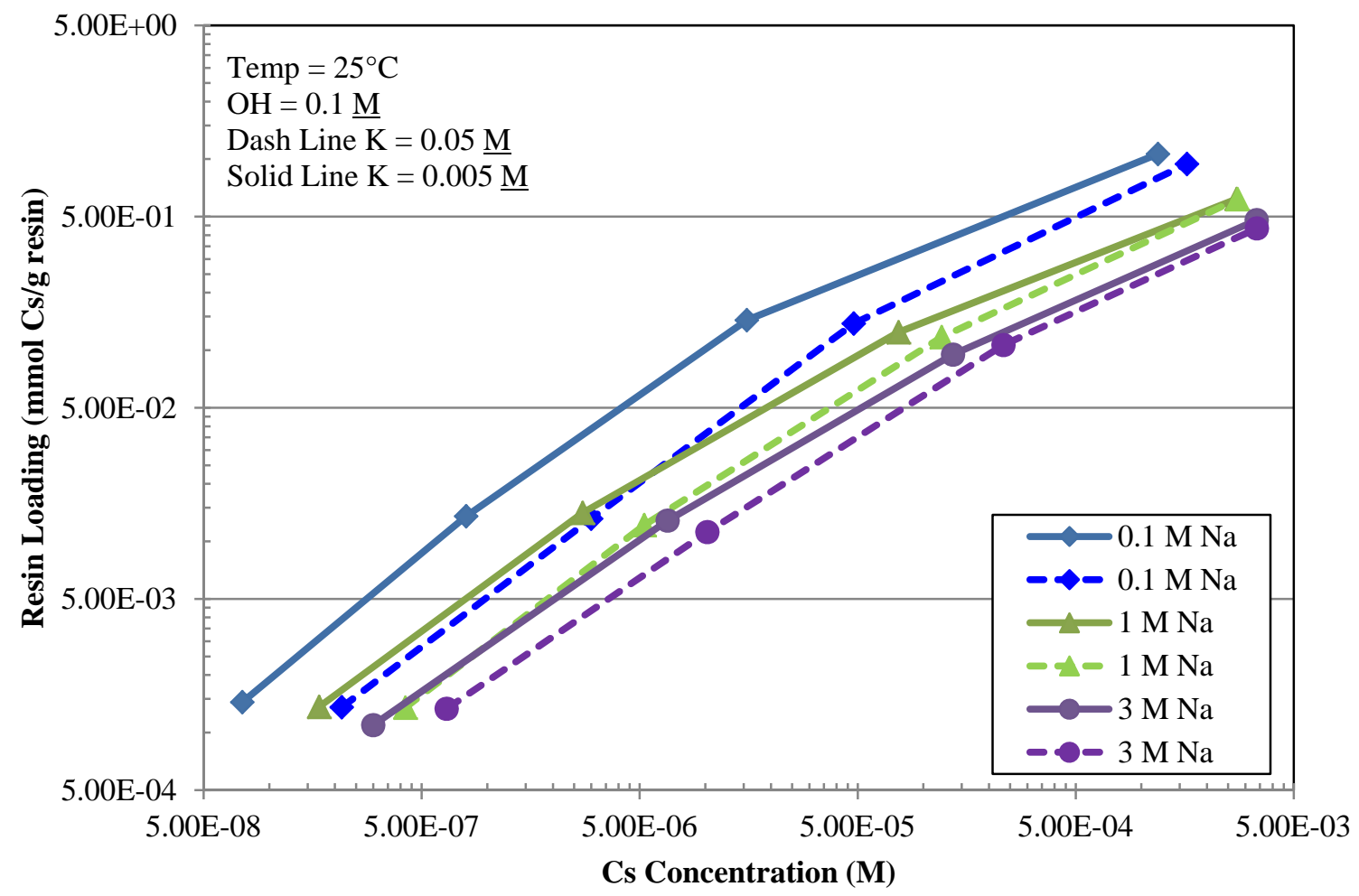

Figure 4.21. K Effect on Cs Loading at $25^{\circ} \mathrm{C}$ and $0.1 \underline{\mathrm{M} \mathrm{OH}}$

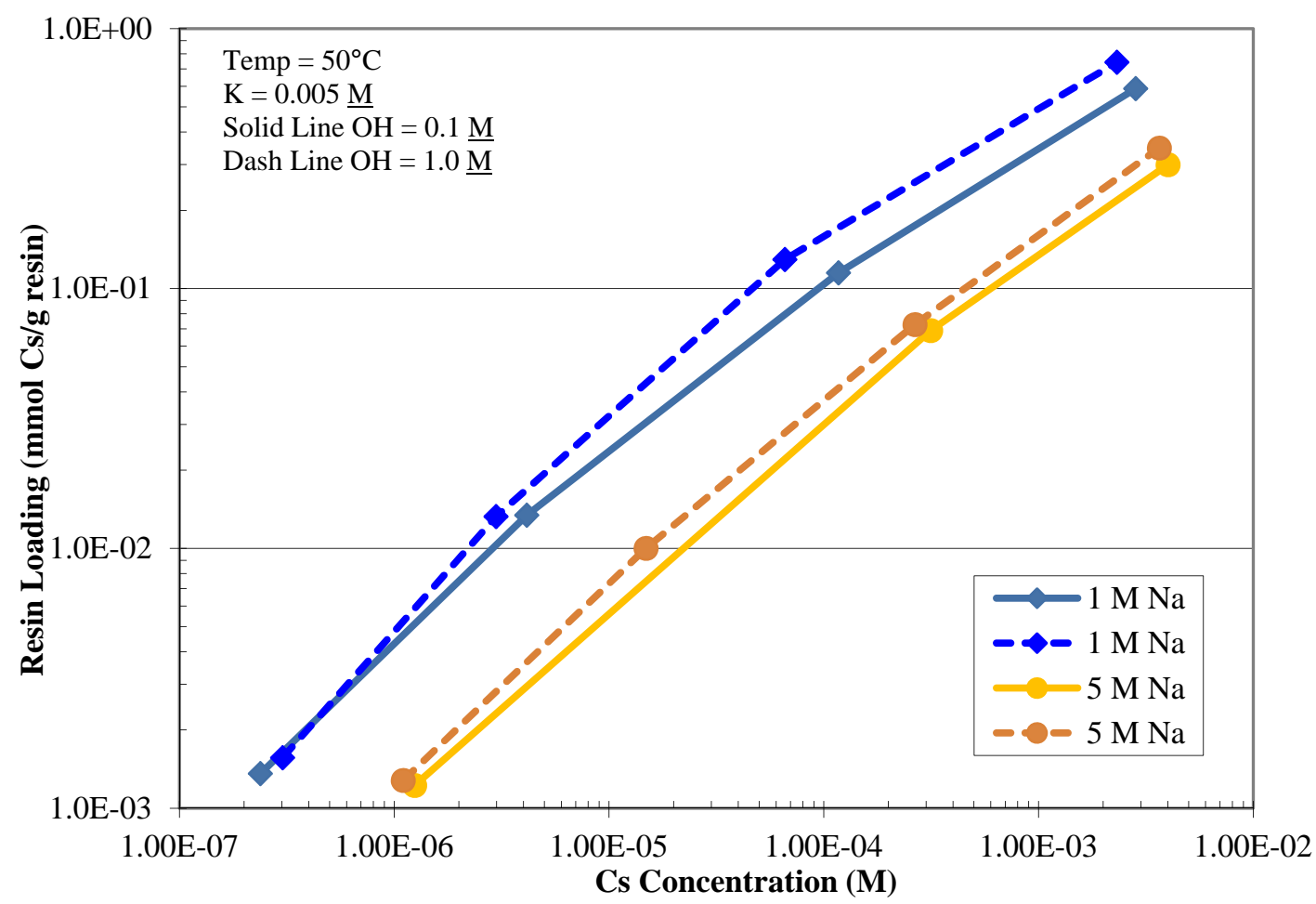

Figure 4.22. $\mathrm{OH}$ Effect on Cs Loading at $50^{\circ} \mathrm{C}$ and $0.005 \underline{\mathrm{M}} \mathrm{K}$ 


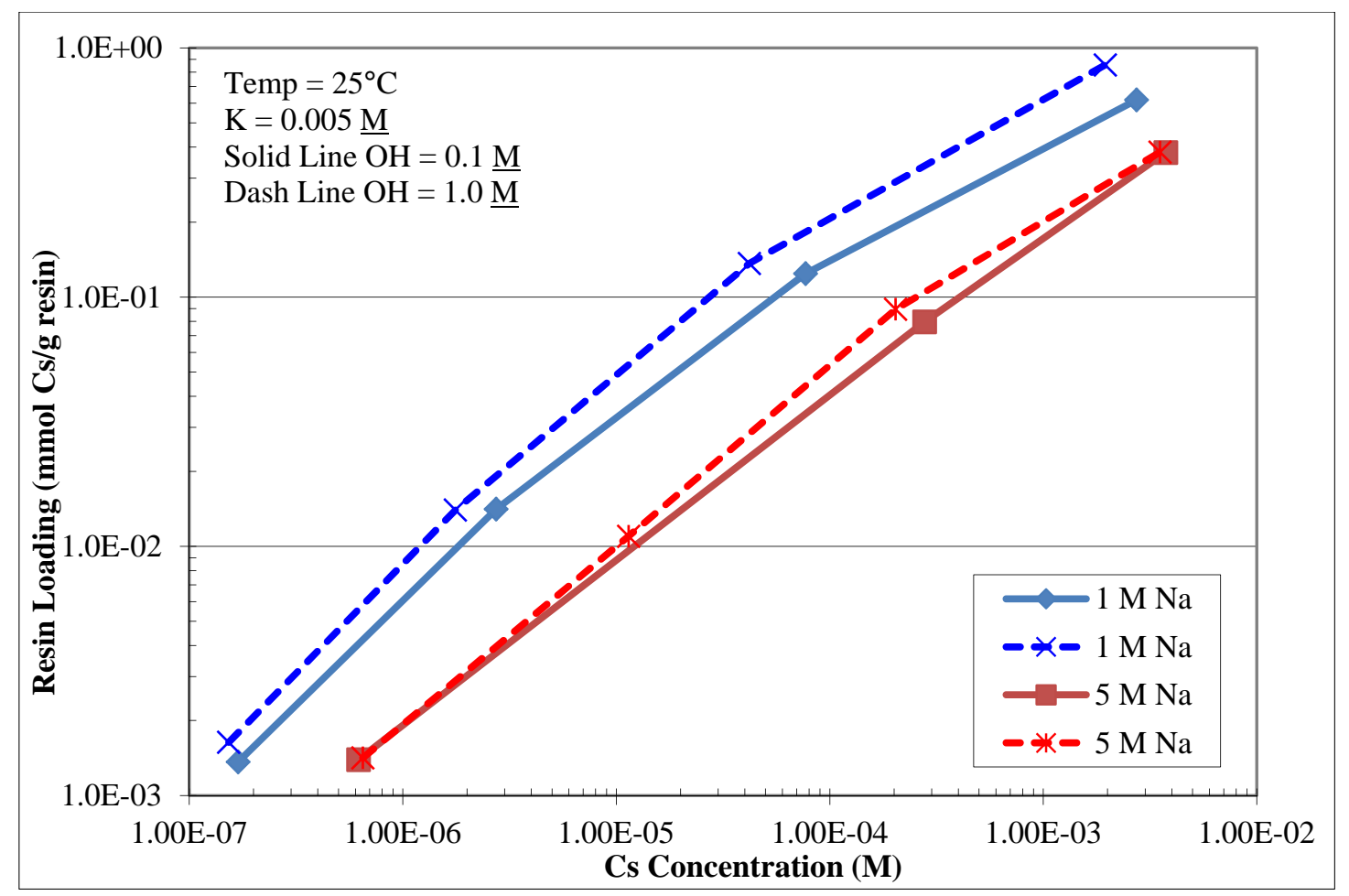

Figure 4.23. $\mathrm{OH}$ Effect on Cs Loading at $25^{\circ} \mathrm{C}$ and $0.005 \underline{\mathrm{M} \mathrm{K}}$

\subsubsection{Temperature Effect on Resin Cs Loading Capacity}

The effect of temperature on the resin loading capacity appears to be dependent on Na concentration with the effect being greater at higher $\mathrm{Na}$. Figure 4.24 shows that at $0.1 \underline{\mathrm{M}} \mathrm{Na}$, temperature has basically no effect on Cs loading, but that the effect of temperature increases with Na concentration. Previous work observed an almost linear effect of temperature on the loading at $4 \underline{\mathrm{M}}$ and $6 \underline{\mathrm{M}} \mathrm{Na}$ (Nash et al. 2006). This may be due to the density/viscosity difference between 0.1 and $5 \underline{M}$ Na solutions, which allows the lower Na solutions to flow more readily through the resin and not be as affected by temperature as the higher Na solutions.

The presence of $\mathrm{K}$ does not appear to make a significant difference in the effect of temperature (Figure 4.25), with only a slight difference seen at low Cs concentrations and no effect seen at higher Cs concentrations. At higher K concentrations, the temperature effect is larger. However, the temperature effect of $\mathrm{OH}$ appears to be dependent on the presence of the other ions (Figure 4.26 and Figure 4.27). At higher $\mathrm{OH}$ concentrations and the lower $\mathrm{Cs}$, $\mathrm{Na}$ and $\mathrm{K}$ concentrations, temperature has a greater effect on Cs loading. At $5 \underline{\mathrm{M}} \mathrm{Na}$ and $0.05 \underline{\mathrm{M}} \mathrm{K}$, Cs loading is essentially the same at both $\mathrm{OH}$ concentrations; however, Cs loading decreases slightly when the temperature is raised to $50^{\circ} \mathrm{C}$. With $1 \underline{\mathrm{M}} \mathrm{Na}$ and $0.005 \underline{\mathrm{M}} \mathrm{K}$, Cs loading was greater at $1.0 \mathrm{M} \mathrm{OH}$ than at $0.1 \underline{\mathrm{M} \mathrm{OH}}$, but Cs loading decreased when the temperature was increased from 25 to $50^{\circ} \mathrm{C}$.

Overall, higher temperatures result in lower equilibrium Cs loadings. Increasing the temperature from 25 to $50^{\circ} \mathrm{C}$ resulted in less Cs being removed from the simulant solution, with the percent decrease dependent on the presence of the other ions. This observation is in agreement with previous work (Nash 
et al. 2006) and implies that if WTP uses a higher temperature in loading the SRF resin, it will obtain a lower equilibrium Cs loading level.

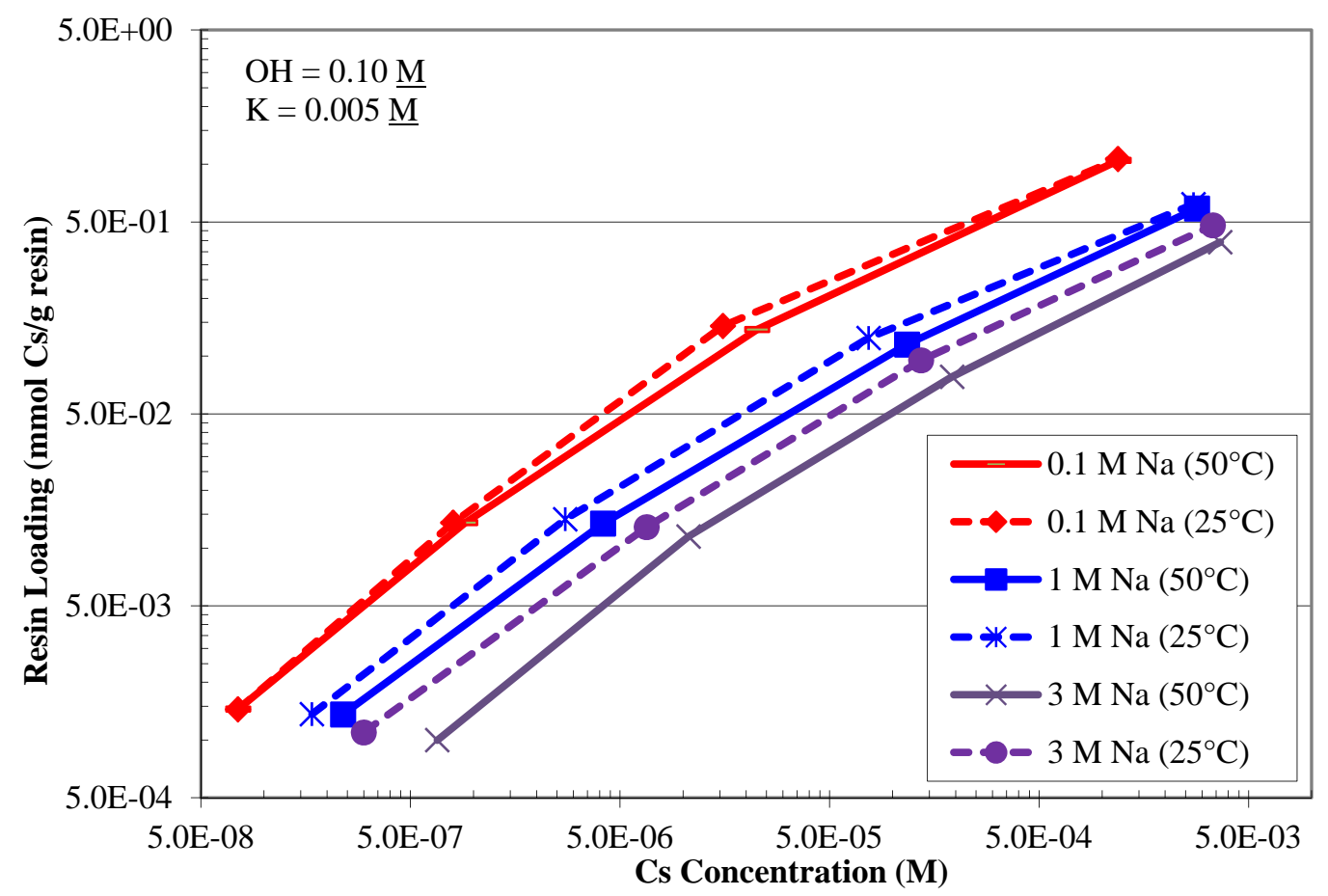

Figure 4.24. Temperature Effect of $\mathrm{Na}$ on Cs Loading at $0.1 \underline{\mathrm{M} \mathrm{OH}}$ and $0.005 \underline{\mathrm{M}} \mathrm{K}$ 


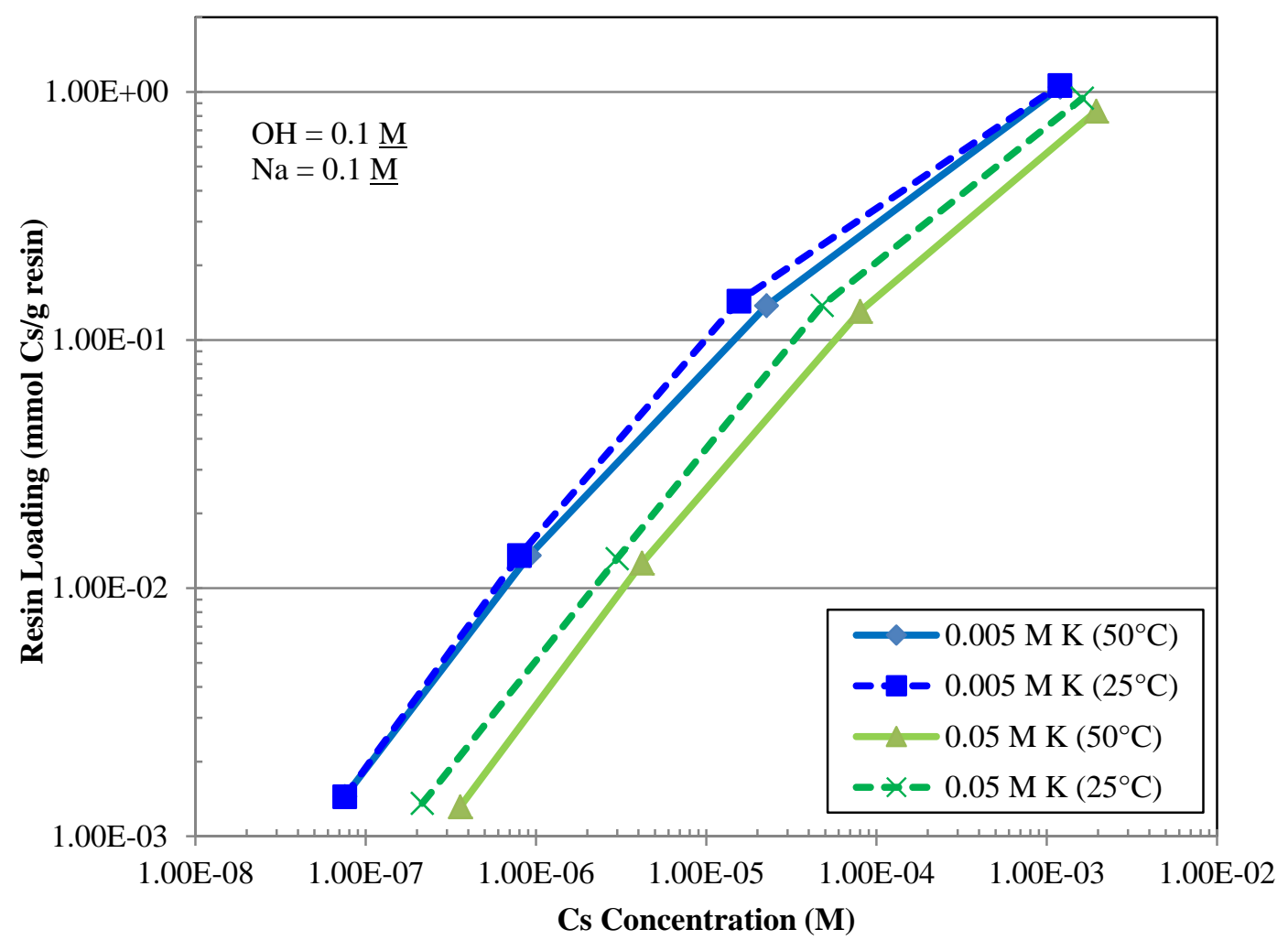

Figure 4.25. Temperature Effect of $\mathrm{K}$ on Cs Loading at $0.1 \underline{\mathrm{M}} \mathrm{OH}$ and $0.1 \underline{\mathrm{M}} \mathrm{Na}$

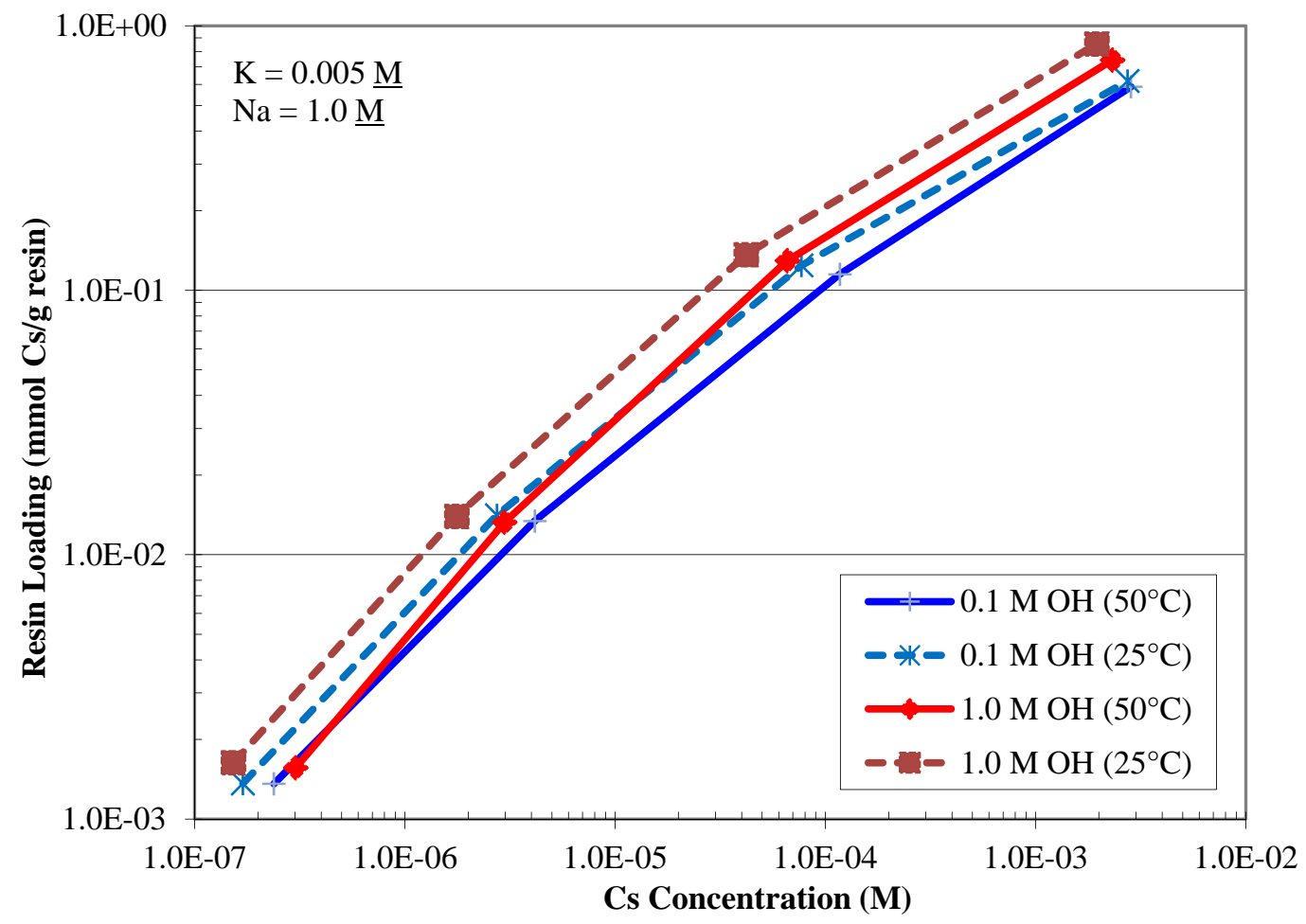

Figure 4.26. Temperature Effect of $\mathrm{OH}$ on Cs Loading at $1.0 \underline{\mathrm{M}} \mathrm{Na}$ and $0.005 \underline{\mathrm{M}} \mathrm{K}$ 


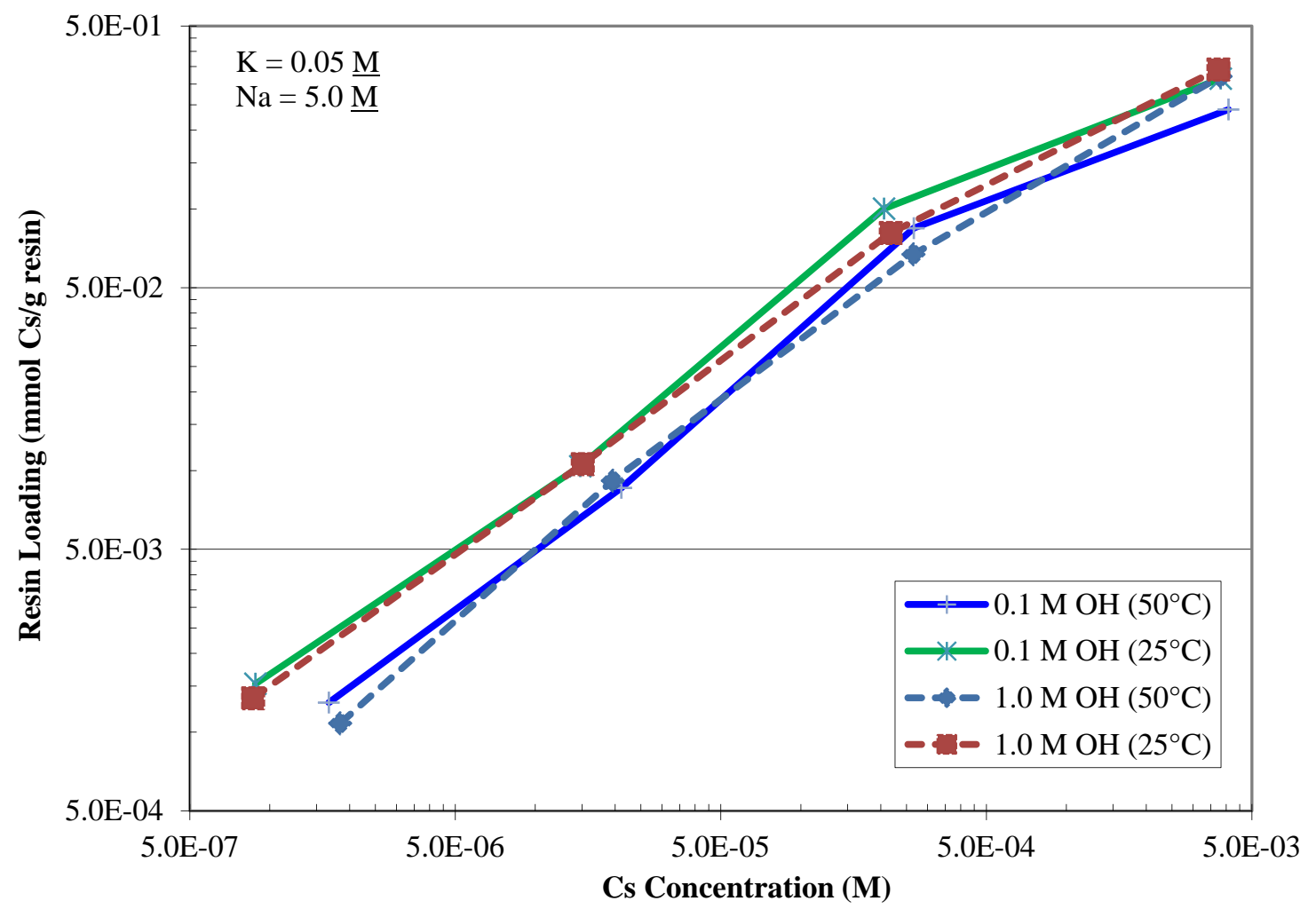

Figure 4.27. Temperature Effect of $\mathrm{OH}$ on Cs Loading at $5.0 \underline{\mathrm{M}} \mathrm{Na}$ and $0.05 \underline{\mathrm{M}} \mathrm{K}$ 


\subsection{Conclusions}

Conclusions from the column testing include the following:

- Linear load velocity did not have a significant effect on the Cs loading kinetics at temperatures of 25, 30, 40, and $45^{\circ} \mathrm{C}$. Previous work (Russell et al. 2012) showed a greater effect of the loading velocity on the Cs loading. The decrease in the impact of velocity with decreasing temperature is somewhat expected. As temperature is decreased, the kinetics of the sorption process will decrease. It would appear that below $45^{\circ} \mathrm{C}$, the sorption process becomes the dominant factor in the Cs loading in place of the mass transfer process, which results in velocity not having a significant effect.

- Temperature had a slight effect, with the Cs loading kinetics increasing slightly with increasing temperature. The 25 and $30^{\circ} \mathrm{C}$ test results were essentially the same and the 40 and $45^{\circ} \mathrm{C}$ test results were essentially the same. However, a slight increase in Cs loading was observed between the 30 and $40^{\circ} \mathrm{C}$ tests. These results indicate that WTP should be able to perform the ion exchange process at up to $45^{\circ} \mathrm{C}$ without significant kinetics and Cs loading effects. In each extended test, regardless of temperature, Cs loading peaked after approximately72 hr and then began to decrease. However, Cs loading decreased less at the lower temperatures. Previous work on Cs loading over a period of time also showed that Cs loading peaked after approximately $72 \mathrm{hr}$ and then began to decrease (Russell et al. 2012). These results indicate that the resin loses Cs loading ability over time and with increased temperature making it unable to hold the Cs over a long period of time at elevated temperatures. Therefore, it follows that WTP will lose resin Cs loading ability at an increased rate if the ion exchange process is performed above $25^{\circ} \mathrm{C}$ for an extended period of time. This indicates that the IX process should be operated at the minimum temperature within the range of $25-45^{\circ} \mathrm{C}$ that is consistent with minimizing the risk of post-filtration precipitation.

- Column plugging was observed in each extended test conducted above $45^{\circ} \mathrm{C}$. Plugging occurred at $336 \mathrm{hr}$ for tests conducted at 55 and $60^{\circ} \mathrm{C}$ and at $600 \mathrm{hr}$ for the test conducted at $50^{\circ} \mathrm{C}$. This presents a significant risk in that the plug could be difficult to remove in a hot cell environment.

Conclusions from the batch testing include the following:

- The Na concentration has a significant effect on Cs loading; the more $\mathrm{Na}$ is present the less Cs is loaded. Previous work also observed this effect (Nash et al. 2006 and Russell et al. 2012). Therefore, the lower the Na level that the PTF processes, the better Cs loading the WTP should obtain on the SRF resin.

- The K concentration appears to have a varying effect on Cs loading. The K effect is greater at lower Cs concentrations, with a Cs loading reduction of about 40 percent at $0.1 \mathrm{M} \mathrm{Na}$, which is attributable to competition for the resin sites between the $\mathrm{K}$ and the Cs. The $\mathrm{K}$ effect is lower at higher Cs concentrations; at the highest Cs concentration tested (0.001 $\underline{\mathrm{M}})$, no significant K effect was observed (approximately 5 percent). Previous studies observed this trend and determined that above a Cs concentration of $0.001 \underline{\mathrm{M}}$, Cs adsorption was more favorable at higher K concentrations (Nash and Isom 2010). Higher concentrations of Cs were not tested here because Hanford waste does not contain those levels of Cs. There was also an inverse effect between $\mathrm{Na}$ and $\mathrm{K}$ with higher $\mathrm{Na}$ bringing less $\mathrm{K}$ effect.

- The $\mathrm{OH}$ concentration does not have a significant effect on the resin Cs loading. OH concentration may have a slightly positive effect at higher Cs concentrations and lower Na concentrations due to the 
rapid de-protonation of resin sites. This conclusion was reached in previous work (Nash and Isom 2010; Nash et al. 2006). Therefore, the presence of OH in the WTP feed may slightly help resin Cs loading but should not make a notable difference, especially in the presence of high Na and $\mathrm{K}$ concentrations.

- The temperature effect on the resin Cs loading appears to be dependent on the Na concentration with the effect being greater at higher Na concentrations. Previous work observed an almost linear effect of temperature on the loading at 4 and $6 \underline{\mathrm{M}} \mathrm{Na}$ (Nash et al. 2006). Higher Na concentration resulted in less Cs loading at higher temperatures.

- No discernible difference in Cs loading was seen between 25 and $35^{\circ} \mathrm{C}$. However, higher temperatures resulted in lower equilibrium Cs loading on the SRF resin. Increasing the temperature from 25 to $50^{\circ} \mathrm{C}$ resulted in a decrease in Cs removed from the simulant solution, with the percent decrease dependent on the presence of the other ions. This was also observed in previous work (Nash et al. 2006) and implies that if WTP uses a higher temperature in loading the SRF resin, it will obtain a lower equilibrium Cs loading level.

Based on the batch and column tests the following overall recommendations are provided:

- It is recommended that maximum routine operating of the SRF columns be limited to less than $45^{\circ} \mathrm{C}$. This is primarily based on the hard resin clumps that formed and plugged the columns during the extended loading tests conducted above $45^{\circ} \mathrm{C}$. The fact that plugging occurred at $336 \mathrm{hr}$ for tests conducted at 55 and $60^{\circ} \mathrm{C}$ and occurred at $600 \mathrm{hr}$ for the $50^{\circ} \mathrm{C}$ test suggests that some limited operation up to $55^{\circ} \mathrm{C}$ may be feasible. However the risk of a column plug that would be difficult to remove in a hot cell environment makes this a risky scenario. The other reason for limiting the routine operating temperature to a maximum of $45^{\circ} \mathrm{C}$ is that the resin degradation increases with temperature.

- It is recommended that the IX process be operated at the minimum temperature within the range of $25-45^{\circ} \mathrm{C}$ that is consistent with minimizing the risk of post-filtration precipitation. The benefits to a lower operating temperature include: increased resin lifetime as result of a slower rate of resin degradation, increased Cs loading on the column due to more favorable equilibrium behavior, and less nitric acid for elution. One slight disadvantage is that a lower temperature results in slightly slower Cs ion exchange rates which will slightly increase the Cs breakthrough from the columns. This disadvantage is mitigated in the WTP by the use of two columns in series. 


\subsection{References}

Adamson DJ, MD Fowley, JL Steimke, TJ Steeper, MR Williams, CE Duffey, and F Fondeur. 2006. Testing of Resorcinol Formaldehyde Ion Exchange Resin. WSRC-TR-2005-00570, SRNL-RPP-2006-00013, Savannah River National Laboratory, Aiken, South Carolina.

Arm ST and DL Blanchard Jr. 2004. Pre-Conditioning and Regeneration Requirements of Ground Gel Resorcinol Formaldehyde Ion Exchange Resin. PNWD-3390, WTP-RPT-104, Battelle-Pacific Northwest Division, Richland, Washington.

ASTM. 2001. American Society for Testing and Materials (ASTM) Method 2687, Standard Practice for Sampling Particulate Ion-Exchange Materials.

Bibler JP, RM Wallace, and LA Bray. 1989. Testing a New Cesium-Specific Ion Exchange Resin for Decontamination of Alkaline High-Activity Waste. WSRC-RP-89-682, Westinghouse Savannah River Company, Savannah River Laboratory, Aiken, South Carolina.

Blanchard Jr DL, SK Fiskum, JM Peterson, AF Farawila, and DE Kurath. 2008. Small Column Ion Exchange Testing for the Near Tank Cesium Removal Project. PNWD-3985, Battelle-Pacific Northwest Division, Richland, Washington.

Bray LA, KJ Carson, RJ Elovich, and DE Kurath. 1996. Equilibrium Data for Cesium Ion Exchange of CC and NCAW Tank Waste. PNNL-11123, Pacific Northwest National Laboratory, Richland, Washington.

Burgeson IE, DL Blanchard Jr, BJ Cook, and JR Deschane. 2004. Elution Testing of Resorcinol Formaldehyde Resins with AN-105 Simulant. PNWD-3388, Battelle-Pacific Northwest Division, Richland, Washington.

Duffey CE, WD King, and LL Hamm. 2003. Determination of Perrhenate ( $\left.\mathrm{ReO}_{4}{ }^{-}\right)$Adsorption Kinetics from Hanford Waste Simulants using SuperLig ${ }^{\circledR} 639$ Resin (U). WSRC-TR-2002-00548, Rev. 0, Savannah River Technology Center, Aiken, South Carolina.

Duignan MR and CA Nash. 2009. Removal of Cesium from Savannah River Site Waste with Spherical Resorcinol Formaldehyde Ion Exchange Resin: Experimental Tests. SRNL-STI-2009-00367, Rev. 0, Savannah River National Laboratory, Aiken, South Carolina.

Ebra MA and RM Wallace. 1983. "Phenolic cation exchange resin material for recovery of cesium and strontium.” US Patent 4,423,159.

Fiskum SK, ST Arm, WC Buchmiller, T Trang-Le, JE Martinez, J Matyas, MJ Steele, KK Thomas, and DL Blanchard, Jr. 2006a. Comparison Testing of Multiple Spherical Resorcinol-Formaldehyde Resins the River Protection Project-Waste Treatment Plant. PNWD-3785, WTP-RPT-143, Battelle-Pacific Northwest Division, Richland, Washington. 
Fiskum SK, ST Arm, MS Fountain, MJ Steele, and DL Blanchard, Jr. 2006b. Spherical Resorcinol Formaldehyde Resin Testing for Cs-137 Removal from Simulated and Actual Hanford Waste Tank 241-AP-101 Diluted Feed (Envelope A) Using Small Column Ion Exchange. PNWD-3697, WTP-RPT-134, Battelle-Pacific Northwest Division, Richland, Washington.

Fiskum SK, MJ Steele, and DL Blanchard Jr. 2006c. Small Column Ion Exchange Testing of Spherical Resorcinol Formaldehyde Resin for Cs-137 Removal from Pre-treated Hanford Tank 241-AN-102 Waste (Envelope C). PNWD-3751, WTP-RPT-135, Battelle-Pacific Northwest Division, Richland, Washington.

Fiskum SK, ST Arm, MK Edwards, MJ Steele, and KK Thomas. 2007. Storage and Aging Effects on Spherical Resorcinol Formaldehyde Resin Ion Exchange Performance. PNNL-16832, WTP-RPT-148, Pacific Northwest National Laboratory, Richland, Washington.

Hassan NM and K Adu-Wusu. 2003. Cesium Removal from Hanford Tank 241-AW-101 Supernate using Resorcinol-Formaldehyde Resin. SRT-RPP-2003-00224, WSRC-TR-2003-00433, Savannah River National Laboratory, Aiken, South Carolina.

Hassan NM, K Adu-Wusu, and JC Marra. 2004. Resorcinol-Formaldehyde Adsorption of Cesium (Cs ${ }^{+}$) from Hanford Waste Solutions_Part I: Batch Equilibrium Study. WSRC-MS-2004-00250, Savannah River National Laboratory, Aiken, South Carolina.

Kim D, MJ Schweiger, and RA Peterson. 2012. Fire Safety Tests for Spherical Resorcinol-Formaldehyde Resin: Data Summary Report. PNNL-21321, WTP-RPT-218, Pacific Northwest National Laboratory, Richland, Washington.

King WD, CE Duffey, and SH Malene. 2004. Determination of Cesium (Cs+) Adsorption Kinetics and Equilibrium Isotherms from Hanford Waste Simulants using Resorcinol-Formaldehyde Resins. WSRC-TR-2003-00574 (SRT-RPP-2003-00252), Rev. 0, Savannah River National Laboratory, Aiken, South Carolina.

Kurath DE, LA Bray, KP Brooks, GN Brown, SA Bryan, CD Carlson, KJ Carson, JR Deschane, RJ Elovich, and AY Kim. 1994. Experimental Data and Analysis to Support the Design of an Ion-Exchange Process for the Treatment of Hanford Tank Waste Supernatant Liquids. PNL-10187, Pacific Northwest Laboratory, Richland, Washington.

Lehrman S. 2010. RF Resin Cesium Removal with Expanded Load and Elution Conditions. WTP Project Doc. No. 24590-PTF-TSP-RT-09-002, Rev. 0, Bechtel National Inc., Richland, Washington.

Meehan JL. 2011. Cesium Ion Exchange Simulant Testing in Support of M-6. WTP Project Doc. No. 24590-PTF-TEF-RT-11-0003, Rev. 0, Bechtel National Inc., Richland, Washington.

Nash CA, MR Duignan, and CE Duffey. 2006. Batch, Kinetics, and Column Data from Spherical Resorcinol-Formaldehyde Resin. WSRC-STI-2006-00071, SRNL-RPP-2006-00024, Savannah River National Laboratory, Aiken, South Carolina.

Nash CA and ST Isom. 2010. Characterization of Spherical Resorcinol-Formaldehyde Resin Cesium Adsorption with Batch Contact Tests. Separation Science and Technology, 45:12-13, 1822 - 1827. 
Peterson RA, SK Fiskum, ST Arm, and DL Blanchard Jr. 2006. Cesium Removal Demonstration Using Selected Actual Waste Samples from the Hanford Reservation Tank Farm. Separation Science and Technology, 41:11, $2361-2371$.

Russell RA, DE Rinehart, GN Brown, PP Schonewill, and RA Peterson. 2012. Ion Exchange Kinetics Testing with SRF Resin. PNNL-21109, WTP-RPT-214, Pacific Northwest National Laboratory, Richland, Washington.

Smith FG. 2007. Modeling of Ion-Exchange for Cesium Removal from Dissolved Saltcake in SRS Tanks 1-3, 37 and 41. Savannah River National Laboratory, WSRC-STI-2007-00315. 

Appendix A

Column Sampling Information 



\section{Appendix A}

\section{Column Sampling Information}

Table A.1. Datasheet for Column A1 Pretreatment, Loading, and Rinsing Information

\begin{tabular}{|c|c|c|c|c|c|c|c|c|c|c|c|c|c|c|}
\hline Sample & Bottle & Temp & Pump & Sampling & Sampling & Resin & Resin & Temp & \multicolumn{3}{|c|}{ Effluent Bottle Weight, g } & \multicolumn{3}{|c|}{ Sample Vial Weight, g } \\
\hline ID No. & $\begin{array}{l}\text { Size } \\
(\mathrm{mL})\end{array}$ & $\begin{array}{c}\text { Set } \\
\left({ }^{\circ} \mathrm{C}\right) \\
\end{array}$ & $\begin{array}{c}\text { Setting } \\
(\mathrm{mL} / \mathrm{min})\end{array}$ & Start Time & Stop Time & $\begin{array}{l}\text { Height } \\
(\mathrm{cm})\end{array}$ & Color & $\left({ }^{\circ} \mathrm{C}\right)$ & Tare & Gross & Net & Tare & Gross & Net \\
\hline A1-PT-DIW1 & 20 & 25 & 0.09 & 2/5/12 14:05 & 2/5/12 17:20 & 1.10 & dark red & 25.4 & 8.57 & 23.68 & 15.11 & NA & NA & NA \\
\hline A1-PT-ACID & 20 & 25 & 0.09 & 2/6/12 9:16 & 2/6/12 12:51 & 1.00 & orange & 25.7 & 8.44 & 25.27 & 16.83 & NA & NA & NA \\
\hline A1-PT-DIW2 & 20 & 25 & 0.09 & 2/6/10 13:00 & 2/6/10 14:00 & 0.90 & orange & 24.8 & 8.53 & 13.19 & 4.66 & NA & NA & NA \\
\hline A1-PT-NaOH & 20 & 25 & 0.09 & 2/6/10 14:10 & 2/6/10 16:25 & 1.25 & dark red & 25.6 & 8.51 & 19.85 & 11.34 & NA & NA & NA \\
\hline A1-LD-0 & 20 & 45 & NA & 2/13/12 6:47 & 2/13/12 6:47 & 1.25 & dark red & 55.2 & NA & NA & NA & 8.47 & 14.82 & 6.35 \\
\hline \multicolumn{4}{|c|}{ Loading (LD) Phase Start Date/Time: } & 2/13/12 6:52 & & & & & & & & & & \\
\hline A1-LD-006 & 20 & 45 & 10.62 & 2/13/12 6:58 & 2/13/12 6:58 & NA & dark red & 52.2 & NA & NA & NA & 8.54 & 12.99 & 4.45 \\
\hline A1-LD-012 & 20 & 45 & 10.62 & 2/13/12 7:04 & 2/13/12 7:04 & NA & dark red & 48.0 & NA & NA & NA & 8.41 & 12.39 & 3.98 \\
\hline A1-LD-018 & 20 & 45 & 10.62 & 2/13/12 7:10 & 2/13/12 7:10 & NA & dark red & 46.4 & NA & NA & NA & 8.54 & 12.76 & 4.22 \\
\hline A1-LD-024 & 20 & 45 & 10.62 & 2/13/12 7:16 & 2/13/12 7:16 & NA & dark red & 45.1 & NA & NA & NA & 8.53 & 12.77 & 4.24 \\
\hline A1-LD-036 & 20 & 45 & 10.62 & 2/13/12 7:28 & 2/13/12 7:28 & NA & dark red & 44.0 & NA & NA & NA & 8.49 & 12.75 & 4.26 \\
\hline A1-LD-048 & 20 & 45 & 10.62 & 2/13/12 7:40 & 2/13/12 7:40 & NA & dark red & 44.3 & NA & NA & NA & 8.59 & 12.78 & 4.19 \\
\hline A1-LD-060 & 20 & 45 & 10.62 & 2/13/12 7:52 & 2/13/12 7:52 & NA & dark red & 44.4 & NA & NA & NA & 8.49 & 12.49 & 4.00 \\
\hline A1-LD-080 & 20 & 45 & 10.62 & 2/13/12 8:12 & 2/13/12 8:12 & NA & dark red & 45.3 & NA & NA & NA & 8.56 & 12.52 & 3.96 \\
\hline A1-LD-120 & 20 & 45 & 10.62 & 2/13/12 8:52 & 2/13/12 8:52 & NA & dark red & 44.9 & NA & NA & NA & 8.41 & 12.80 & 4.39 \\
\hline A1-LD-180 & 20 & 45 & 10.62 & 2/13/12 9:52 & 2/13/12 9:52 & NA & dark red & 44.8 & NA & NA & NA & 8.49 & 12.71 & 4.22 \\
\hline A1-LD-240 & 20 & 45 & 10.62 & 2/13/12 10:52 & 2/13/12 10:52 & NA & dark red & 45.2 & NA & NA & NA & 8.44 & 12.27 & 3.83 \\
\hline A1-LD-600 & 20 & 45 & 10.62 & 2/13/12 16:52 & 2/13/12 16:52 & NA & dark red & 45.1 & NA & NA & NA & 8.46 & 12.77 & 4 \\
\hline A1-FD-CP & 20 & 45 & 0.09 & 2/13/12 17:10 & 2/13/12 19:40 & NA & dark red & 45.2 & 8.51 & 22.65 & 14.14 & NA & NA & NA \\
\hline A1-FDI-CP & 20 & 45 & 0.09 & 2/13/12 20:05 & 2/13/12 22:35 & 1.25 & dark red & 26.1 & 8.38 & 20.90 & 12.52 & NA & NA & NA \\
\hline A1-AN-CP & 20 & 45 & 0.09 & 2/13/12 22:40 & 2/13/12 23:40 & 1.25 & dark red & 25.3 & 8.65 & 13.29 & 4.64 & NA & NA & NA \\
\hline
\end{tabular}


Table A.2. Datasheet for Column A1 Elution, Rinsing, and Regeneration Information

\begin{tabular}{|c|c|c|c|c|c|c|c|c|c|c|c|c|c|c|}
\hline Sample & Bottle & Temp & Pump & Sampling & Sampling & Resin & Resin & Temp & \multicolumn{3}{|c|}{ Effluent Bottle Weight, g } & \multicolumn{3}{|c|}{ Sample Vial Weight, g } \\
\hline ID No. & $\begin{array}{l}\text { Size } \\
(\mathrm{mL})\end{array}$ & $\begin{array}{l}\text { Set } \\
\left({ }^{\circ} \mathrm{C}\right)\end{array}$ & $\begin{array}{c}\text { Setting } \\
(\mathrm{mL} / \mathrm{min})\end{array}$ & Start Time & Stop Time & $\begin{array}{c}\text { Height } \\
(\mathrm{cm})\end{array}$ & Color & $\left({ }^{\circ} \mathrm{C}\right)$ & Tare & Gross & Net & Tare & Gross & Net \\
\hline \multicolumn{4}{|c|}{ Elution (EL) Phase Start Date/Time: } & $2 / 14 / 126: 50$ & & & & & & & & & & \\
\hline A1-EL-CP & 60 & 25 & 0.08 & 2/14/12 6:50 & 2/14/12 16:50 & 1.05 & orange & 25.4 & 14.79 & 60.84 & 46.05 & 8.47 & 19.35 & 10.88 \\
\hline A1-EDI-CP & 20 & 25 & 0.09 & 2/14/12 17:10 & 2/14/12 18:10 & 1.05 & orange & 25.0 & 8.50 & 13.32 & 4.82 & NA & NA & NA \\
\hline A1-RG-CP & 20 & 25 & 0.09 & 2/14/12 18:17 & 2/14/12 20:47 & 1.25 & dark red & 26.5 & 8.57 & 20.75 & 12.18 & NA & NA & NA \\
\hline
\end{tabular}

Table A.3. Datasheet for Column A2 Loading and Rinsing Information

\begin{tabular}{|c|c|c|c|c|c|c|c|c|c|c|c|c|c|c|}
\hline Sample & Bottle & Temp & Pump & Sampling & Sampling & Resin & Resin & Temp & \multicolumn{3}{|c|}{ Effluent Bottle Weight, g } & \multicolumn{3}{|c|}{ Sample Vial Weight, g } \\
\hline ID No. & $\begin{array}{l}\text { Size } \\
(\mathrm{mL})\end{array}$ & Set $\left({ }^{\circ} \mathrm{C}\right)$ & $\begin{array}{c}\text { Setting } \\
\text { (mL/min) }\end{array}$ & Start Time & Stop Time & $\begin{array}{l}\text { Height } \\
(\mathrm{cm})\end{array}$ & Color & $\left({ }^{\circ} \mathrm{C}\right)$ & Tare & Gross & Net & Tare & Gross & Net \\
\hline A2-LD-0 & 20 & 45 & NA & 2/15/12 6:47 & 2/15/12 6:47 & 1.25 & dark red & 55.1 & NA & NA & NA & 8.56 & 12.93 & 4.37 \\
\hline \multicolumn{4}{|c|}{ Loading (LD) Phase Start Date/Time: } & 2/15/12 6:50 & & & & & & & & & & \\
\hline A2-LD-006 & 20 & 45 & 14.16 & 2/15/12 6:56 & 2/15/12 6:56 & NA & dark red & 49.5 & NA & NA & NA & 8.39 & 12.53 & 4.14 \\
\hline A2-LD-012 & 20 & 45 & 14.16 & 2/15/12 7:02 & 2/15/12 7:02 & NA & dark red & 46.8 & NA & NA & NA & 8.58 & 12.97 & 4.39 \\
\hline A2-LD-018 & 20 & 45 & 14.16 & 2/15/12 7:08 & 2/15/12 7:08 & NA & dark red & 45.1 & NA & NA & NA & 8.46 & 12.84 & 4.38 \\
\hline A2-LD-024 & 20 & 45 & 14.16 & 2/15/12 7:14 & 2/15/12 7:14 & NA & dark red & 44.0 & NA & NA & NA & 8.39 & 12.64 & 4.25 \\
\hline A2-LD-036 & 20 & 45 & 14.16 & 2/15/12 7:26 & 2/15/12 7:26 & NA & dark red & 43.8 & NA & NA & NA & 8.50 & 13.05 & 4.55 \\
\hline A2-LD-048 & 20 & 45 & 14.16 & 2/15/12 7:38 & 2/15/12 7:38 & NA & dark red & 44.3 & NA & NA & NA & 8.54 & 13.06 & 4.52 \\
\hline A2-LD-060 & 20 & 45 & 14.16 & 2/15/12 7:50 & 2/15/12 7:50 & NA & dark red & 44.8 & NA & NA & NA & 8.48 & 12.88 & 4.40 \\
\hline A2-LD-080 & 20 & 45 & 14.16 & 2/15/12 8:10 & 2/15/12 8:10 & NA & dark red & 45.1 & NA & NA & NA & 8.44 & 12.83 & 4.39 \\
\hline A2-LD-120 & 20 & 45 & 14.16 & 2/15/12 8:50 & 2/15/12 8:50 & NA & dark red & 45.2 & NA & NA & NA & 8.42 & 12.95 & 4.53 \\
\hline A2-LD-180 & 20 & 45 & 14.16 & 2/15/12 9:50 & 2/15/12 9:50 & NA & dark red & 45.1 & NA & NA & NA & 8.50 & 13.04 & 4.54 \\
\hline A2-LD-240 & 20 & 45 & 14.16 & $2 / 15 / 12$ 10:50 & $2 / 15 / 12$ 10:50 & NA & dark red & 45.0 & NA & NA & NA & 8.50 & 12.92 & 4.42 \\
\hline A2-LD-600 & 20 & 45 & 14.16 & 2/15/12 16:50 & 2/15/12 16:50 & NA & dark red & 45.2 & NA & NA & NA & 8.55 & 13.12 & 4.57 \\
\hline A2-FD-CP & 20 & 45 & 0.09 & 2/15/12 17:07 & 2/15/12 19:37 & 1.25 & dark red & 45.2 & 8.44 & 22.44 & 14.00 & NA & NA & NA \\
\hline A2-FDI-CP & 20 & 25 & 0.09 & 2/15/12 19:50 & 2/15/12 22:20 & 1.25 & dark red & 25.7 & 8.47 & 20.84 & 12.37 & NA & NA & NA \\
\hline A2-AN-CP & 20 & 25 & 0.09 & 2/15/12 22:25 & 2/15/12 23:25 & 1.25 & dark red & 25.4 & 8.60 & 13.47 & 4.87 & NA & NA & NA \\
\hline
\end{tabular}


Table A.4. Datasheet for Column A2 Elution, Rinsing, and Regeneration Information

\begin{tabular}{|c|c|c|c|c|c|c|c|c|c|c|c|c|c|c|}
\hline Sample & Bottle & Temp & Pump & Sampling & Sampling & Resin & Resin & Temp & \multicolumn{3}{|c|}{ Effluent Bottle Weight, g } & \multicolumn{3}{|c|}{ Sample Vial Weight, g } \\
\hline ID No. & $\begin{array}{l}\text { Size } \\
(\mathrm{mL})\end{array}$ & $\begin{array}{l}\text { Set } \\
\left({ }^{\circ} \mathrm{C}\right)\end{array}$ & $\begin{array}{c}\text { Setting } \\
\text { (mL/min) }\end{array}$ & Start Time & Stop Time & $\begin{array}{l}\text { Height } \\
(\mathrm{cm})\end{array}$ & Color & $\left({ }^{\circ} \mathrm{C}\right)$ & Tare & Gross & Net & Tare & Gross & Net \\
\hline \multicolumn{4}{|c|}{ Elution (EL) Phase Start Date/Time: } & 2/16/12 6:44 & & & & & & & & & & \\
\hline A2-EL-CP & 60 & 25 & 0.08 & 2/16/12 6:44 & 2/16/12 17:14 & 1.10 & orange & 25.9 & 14.90 & 60.83 & 45.93 & 8.46 & 16.76 & 8.30 \\
\hline A2-EDI-CP & 20 & 25 & 0.09 & 2/16/12 17:27 & 2/16/12 18:27 & 1.10 & orange & 25.1 & 8.51 & 13.31 & 4.80 & NA & NA & NA \\
\hline A2-RG-CP & 20 & 25 & 0.09 & 2/16/12 18:33 & 2/16/12 21:03 & 1.25 & dark red & 25.5 & 8.62 & 20.59 & 11.97 & NA & NA & NA \\
\hline
\end{tabular}

Table A.5. Datasheet for Column A3 Loading and Rinsing Information

\begin{tabular}{|c|c|c|c|c|c|c|c|c|c|c|c|c|c|c|}
\hline Sample & Bottle & Temp & Pump & Sampling & Sampling & Resin & Resin & Temp & \multicolumn{3}{|c|}{ Effluent Bottle Weight, g } & \multicolumn{3}{|c|}{ Sample Vial Weight, g } \\
\hline ID No. & $\begin{array}{l}\text { Size } \\
(\mathrm{mL})\end{array}$ & $\begin{array}{l}\text { Set } \\
\left({ }^{\circ} \mathrm{C}\right)\end{array}$ & $\begin{array}{c}\text { Setting } \\
\text { (mL/min) }\end{array}$ & Start Time & Stop Time & $\begin{array}{l}\text { Height } \\
\text { (cm) }\end{array}$ & Color & $\left({ }^{\circ} \mathrm{C}\right)$ & Tare & Gross & Net & Tare & Gross & Net \\
\hline A3-LD-0 & 20 & 45 & NA & $2 / 21 / 126: 51$ & 2/21/12 6:51 & 1.35 & dark red & 52.2 & NA & NA & NA & 8.54 & 13.11 & 4.57 \\
\hline \multicolumn{4}{|c|}{ Loading (LD) Phase Start Date/Time: } & 2/21/12 6:55 & & & & & & & & & & \\
\hline A3-LD-006 & 20 & 45 & 7.08 & 2/21/12 7:01 & 2/21/12 7:01 & NA & dark red & 48.6 & NA & NA & NA & 8.51 & 12.87 & 4.36 \\
\hline A3-LD-012 & 20 & 45 & 7.08 & 2/21/12 7:07 & 2/21/12 7:07 & NA & dark red & 46.8 & NA & NA & NA & 8.66 & 13.12 & 4.46 \\
\hline A3-LD-018 & 20 & 45 & 7.08 & 2/21/12 7:13 & 2/21/12 7:13 & NA & dark red & 45.6 & NA & NA & NA & 8.68 & 13.36 & 4.68 \\
\hline A3-LD-024 & 20 & 45 & 7.08 & 2/21/12 7:19 & 2/21/12 7:19 & NA & dark red & 44.8 & NA & NA & NA & 8.61 & 13.02 & 4.41 \\
\hline A3-LD-036 & 20 & 45 & 7.08 & 2/21/12 7:31 & 2/21/12 7:31 & NA & dark red & 44.6 & NA & NA & NA & 8.68 & 12.79 & 4.11 \\
\hline A3-LD-048 & 20 & 45 & 7.08 & 2/21/12 7:43 & 2/21/12 7:43 & NA & dark red & 44.8 & NA & NA & NA & 8.58 & 12.39 & 3.81 \\
\hline A3-LD-060 & 20 & 45 & 7.08 & 2/21/12 7:55 & 2/21/12 7:55 & NA & dark red & 44.9 & NA & NA & NA & 8.49 & 13.04 & 4.55 \\
\hline A3-LD-080 & 20 & 45 & 7.08 & 2/21/12 8:15 & 2/21/12 8:15 & NA & dark red & 44.9 & NA & NA & NA & 8.67 & 13.43 & 4.76 \\
\hline A3-LD-120 & 20 & 45 & 7.08 & 2/21/12 8:55 & 2/21/12 8:55 & NA & dark red & 44.8 & NA & NA & NA & 8.50 & 12.99 & 4.49 \\
\hline A3-LD-180 & 20 & 45 & 7.08 & 2/21/12 9:55 & 2/21/12 9:55 & NA & dark red & 44.9 & NA & NA & NA & 8.46 & 13.02 & 4.56 \\
\hline A3-LD-240 & 20 & 45 & 7.08 & 2/21/12 10:55 & 2/21/12 10:55 & NA & dark red & 44.9 & NA & NA & NA & 8.61 & 12.63 & 4.02 \\
\hline A3-LD-600 & 20 & 45 & 7.08 & 2/21/12 16:55 & 2/21/12 16:55 & NA & dark red & 45.1 & NA & NA & NA & 8.61 & 13.01 & 4.40 \\
\hline A3-FD-CP & 20 & 45 & 0.09 & 2/21/12 17:08 & 2/21/12 19:38 & NA & dark red & 44.9 & 8.49 & 22.39 & 13.90 & NA & NA & NA \\
\hline A3-FDI-CP & 20 & 25 & 0.09 & 2/21/12 19:45 & 2/21/12 22:15 & NA & dark red & 25.6 & 8.45 & 20.97 & 12.52 & NA & NA & NA \\
\hline A3-AN-CP & 20 & 25 & 0.09 & 2/21/12 22:22 & 2/21/12 23:17 & NA & dark red & 25.5 & 8.46 & 13.07 & 4.61 & NA & NA & NA \\
\hline
\end{tabular}


Table A.6. Datasheet for Column A3 Elution, Rinsing, and Regeneration Information

\begin{tabular}{|c|c|c|c|c|c|c|c|c|c|c|c|c|c|c|}
\hline Sample & Bottle & Temp & Pump & Sampling & Sampling & Resin & Resin & Temp & \multicolumn{3}{|c|}{ Effluent Bottle Weight, g } & \multicolumn{3}{|c|}{ Sample Vial Weight, g } \\
\hline ID No. & $\begin{array}{l}\text { Size } \\
(\mathrm{mL})\end{array}$ & $\begin{array}{l}\text { Set } \\
\left({ }^{\circ} \mathrm{C}\right)\end{array}$ & $\begin{array}{c}\text { Setting } \\
(\mathrm{mL} / \mathrm{min})\end{array}$ & Start Time & Stop Time & $\begin{array}{c}\text { Height } \\
(\mathrm{cm})\end{array}$ & Color & $\left({ }^{\circ} \mathrm{C}\right)$ & Tare & Gross & Net & Tare & Gross & Net \\
\hline \multicolumn{4}{|c|}{ Elution (EL) Phase Start Date/Time: } & 2/22/12 6:47 & & & & & & & & & & \\
\hline A3-EL-CP & 60 & 25 & 0.08 & 2/22/12 6:47 & $2 / 22 / 1216: 50$ & 1.30 & orange & 26.4 & 14.63 & 58.95 & 44.32 & 8.66 & 19.22 & 10.56 \\
\hline A3-EDI-CP & 20 & 25 & 0.09 & 2/22/12 17:01 & 2/22/12 18:01 & 1.30 & orange red & 25.3 & 8.61 & 13.27 & 4.66 & NA & NA & NA \\
\hline A3-RG-CP & 20 & 25 & 0.09 & 2/22/12 18:07 & 2/22/12 20:47 & 1.35 & dark red & 26.2 & 8.51 & 21.29 & 12.78 & NA & NA & NA \\
\hline
\end{tabular}

Table A.7. Datasheet for Column A4 Loading and Rinsing Information

\begin{tabular}{|c|c|c|c|c|c|c|c|c|c|c|c|c|c|c|}
\hline Sample & Bottle & Temp & Pump & Sampling & Sampling & Resin & Resin & Temp & \multicolumn{3}{|c|}{ Effluent Bottle Weight, g } & \multicolumn{3}{|c|}{ Sample Vial Weight, g } \\
\hline ID No. & $\begin{array}{l}\text { Size } \\
(\mathrm{mL})\end{array}$ & $\begin{array}{l}\text { Set } \\
\left({ }^{\circ} \mathrm{C}\right)\end{array}$ & $\begin{array}{l}\text { Setting } \\
\text { (mL/min) }\end{array}$ & Start Time & Stop Time & $\begin{array}{l}\text { Height } \\
(\mathrm{cm})\end{array}$ & Color & $\left({ }^{\circ} \mathrm{C}\right)$ & Tare & Gross & Net & Tare & Gross & Net \\
\hline A4-LD-0 & 20 & 45 & NA & 2/23/12 6:47 & 2/23/12 6:47 & 1.35 & dark red & 51.8 & NA & NA & NA & 8.52 & 13.10 & 4.58 \\
\hline \multicolumn{4}{|c|}{ Loading (LD) Phase Start Date/Time: } & 2/23/12 6:50 & & & & & & & & & & \\
\hline A4-LD-006 & 20 & 45 & 10.62 & 2/23/12 6:56 & 2/23/12 6:56 & NA & dark red & 47.9 & NA & NA & NA & 8.58 & 12.97 & 4.39 \\
\hline A4-LD-012 & 20 & 45 & 10.62 & 2/23/12 7:02 & 2/23/12 7:02 & NA & dark red & 45.2 & NA & NA & NA & 8.69 & 12.81 & 4.12 \\
\hline A4-LD-018 & 20 & 45 & 10.62 & 2/23/12 7:08 & 2/23/12 7:08 & NA & dark red & 44.1 & NA & NA & NA & 8.66 & 13.01 & 4.35 \\
\hline A4-LD-024 & 20 & 45 & 10.62 & 2/23/12 7:14 & 2/23/12 7:14 & NA & dark red & 44.1 & NA & NA & NA & 8.44 & 12.83 & 4.39 \\
\hline A4-LD-036 & 20 & 45 & 10.62 & 2/23/12 7:26 & 2/23/12 7:26 & NA & dark red & 44.9 & NA & NA & NA & 8.51 & 12.67 & 4.16 \\
\hline A4-LD-048 & 20 & 45 & 10.62 & 2/23/12 7:38 & 2/23/12 7:38 & NA & dark red & 45.2 & NA & NA & NA & 8.56 & 13.01 & 4.45 \\
\hline A4-LD-060 & 20 & 45 & 10.62 & 2/23/12 7:50 & $2 / 23 / 127: 50$ & NA & dark red & 45.2 & NA & NA & NA & 8.62 & 13.11 & 4.49 \\
\hline A4-LD-080 & 20 & 45 & 10.62 & 2/23/12 8:10 & 2/23/12 8:10 & NA & dark red & 44.8 & NA & NA & NA & 8.66 & 13.01 & 4.35 \\
\hline A4-LD-120 & 20 & 45 & 10.62 & 2/23/12 8:50 & 2/23/12 8:50 & NA & dark red & 44.5 & NA & NA & NA & 8.63 & 13.01 & 4.38 \\
\hline A4-LD-180 & 20 & 45 & 10.62 & 2/23/12 9:50 & 2/23/12 9:50 & NA & dark red & 44.8 & NA & NA & NA & 8.53 & 13.07 & 4.54 \\
\hline A4-LD-240 & 20 & 45 & 10.62 & 2/23/12 10:50 & 2/23/12 10:50 & NA & dark red & 44.5 & NA & NA & NA & 8.55 & 13.00 & 4.45 \\
\hline A4-LD-600 & 20 & 45 & 10.62 & 2/23/12 16:50 & 2/23/12 16:50 & NA & dark red & 45.3 & NA & NA & NA & 8.58 & 12.95 & 4.37 \\
\hline A4-FD-CP & 20 & 45 & 0.09 & 2/23/12 17:06 & 2/23/12 19:36 & NA & dark red & 45.3 & 8.46 & 22.63 & 14.17 & NA & NA & NA \\
\hline A4-FDI-CP & 20 & 25 & 0.09 & 2/23/12 19:54 & 2/23/12 21:54 & NA & dark red & 25.7 & 8.58 & 18.87 & 10.29 & NA & NA & NA \\
\hline
\end{tabular}


Table A.8. Datasheet for Column A4B Loading and Rinsing Information

\begin{tabular}{|c|c|c|c|c|c|c|c|c|c|c|c|c|c|c|}
\hline \multirow{2}{*}{$\begin{array}{l}\text { Sample } \\
\text { ID No. }\end{array}$} & \multirow{2}{*}{$\begin{array}{c}\text { Bottle } \\
\text { Size } \\
(\mathrm{mL})\end{array}$} & \multirow{2}{*}{$\begin{array}{c}\text { Temp } \\
\text { Set } \\
\left({ }^{\circ} \mathrm{C}\right)\end{array}$} & \multirow{2}{*}{$\begin{array}{c}\text { Pump } \\
\text { Setting } \\
(\mathrm{mL} / \mathrm{min})\end{array}$} & \multirow{2}{*}{$\begin{array}{l}\text { Sampling } \\
\text { Start Time }\end{array}$} & \multirow{2}{*}{$\begin{array}{l}\text { Sampling } \\
\text { Stop Time }\end{array}$} & \multirow{2}{*}{$\begin{array}{c}\text { Resin } \\
\begin{array}{c}\text { Height } \\
(\mathrm{cm})\end{array}\end{array}$} & \multirow{2}{*}{$\begin{array}{l}\text { Resin } \\
\text { Color } \\
\end{array}$} & \multirow{2}{*}{$\begin{array}{l}\text { Temp } \\
\left({ }^{\circ} \mathrm{C}\right)\end{array}$} & \multicolumn{3}{|c|}{ Effluent Bottle Weight, g } & \multicolumn{3}{|c|}{ Sample Vial Weight, g } \\
\hline & & & & & & & & & Tare & Gross & Net & Tare & Gross & Net \\
\hline A4B-LD-0 & 20 & 60 & NA & 2/29/12 8:47 & 2/29/12 8:47 & 1.30 & dark red & 59.8 & NA & NA & NA & 8.41 & 12.66 & 4.25 \\
\hline \multicolumn{4}{|c|}{ Loading (LD) Phase Start Date/Time: } & 2/29/12 9:00 & & & & & & & & & & \\
\hline A4B-LD-004 & 20 & 60 & 0.08 & 2/29/12 13:00 & 2/29/12 13:00 & NA & dark red & 60.0 & NA & NA & NA & 8.42 & 12.41 & 3.99 \\
\hline A4B-LD-008 & 20 & 60 & 0.08 & 2/29/12 17:00 & 2/29/12 17:00 & NA & dark red & 60.1 & NA & NA & NA & 8.51 & 13.05 & 4.54 \\
\hline A4B-LD-012 & 20 & 60 & 0.08 & 2/29/12 21:00 & 2/29/12 21:00 & NA & dark red & 60.1 & NA & NA & NA & 8.49 & 12.92 & 4.43 \\
\hline A4B-LD-024 & 20 & 60 & 0.08 & 3/1/12 9:00 & 3/1/12 9:00 & NA & dark red & 60.1 & NA & NA & NA & 8.36 & 12.91 & 4.55 \\
\hline A4B-LD-072 & 20 & 60 & 0.08 & 3/3/12 9:00 & 3/3/12 9:00 & NA & dark red & 60.1 & NA & NA & NA & 8.54 & 13.03 & 4.49 \\
\hline A4B-LD-120 & 20 & 60 & 0.08 & 3/5/12 9:00 & 3/5/12 9:00 & NA & dark red & 60.0 & NA & NA & NA & 8.46 & 12.97 & 4.51 \\
\hline A4B-LD-168 & 20 & 60 & 0.08 & 3/7/12 9:00 & 3/7/12 9:00 & NA & dark red & 59.8 & NA & NA & NA & 8.49 & 13.14 & 4.65 \\
\hline A4B-LD-336 & 20 & 60 & 0.08 & 3/14/12 9:00 & 3/14/12 9:00 & NA & dark red & 60.5 & NA & NA & NA & 8.43 & 12.85 & 4.42 \\
\hline A4B-FD-CP & 20 & 60 & 0.08 & 3/15/12 9:20 & $3 / 15 / 12$ 11:50 & NA & dark red & 60.4 & 8.40 & 20.88 & 12.48 & NA & NA & NA \\
\hline A4B-FDI-CP & 20 & 25 & 0.09 & 3/15/12 12:10 & 3/15/12 14:42 & NA & dark red & 26.3 & 8.45 & 21.23 & 12.78 & NA & NA & NA \\
\hline A4B-AN-CP & 20 & 25 & 0.09 & 3/15/12 14:52 & 3/15/12 15:53 & NA & dark red & 26.9 & 8.47 & 13.64 & 5.17 & NA & NA & NA \\
\hline
\end{tabular}

Table A.9. Datasheet for Column A4B Elution, Rinsing, and Regeneration Information

\begin{tabular}{|c|c|c|c|c|c|c|c|c|c|c|c|c|c|c|}
\hline Sample & Bottle & Temp & Pump & Sampling & Sampling & Resin & Resin & Temp & \multicolumn{3}{|c|}{ Effluent Bottle Weight, g } & \multicolumn{3}{|c|}{ Sample Vial Weight, g } \\
\hline ID No. & $\begin{array}{l}\text { Size } \\
(\mathrm{mL})\end{array}$ & $\begin{array}{l}\text { Set } \\
\left({ }^{\circ} \mathrm{C}\right)\end{array}$ & $\begin{array}{l}\text { Setting } \\
\text { (mL/min) }\end{array}$ & Start Time & Stop Time & $\begin{array}{l}\text { Height } \\
(\mathrm{cm})\end{array}$ & Color & $\left({ }^{\circ} \mathrm{C}\right)$ & Tare & Gross & Net & Tare & Gross & Net \\
\hline \multicolumn{4}{|c|}{ Elution (EL) Phase Start Date/Time: } & 3/19/12 6:40 & & & & & & & & & & \\
\hline A4B-EL-CP & 60 & 25 & 0.08 & $3 / 19 / 126: 40$ & 3/19/12 17:40 & 1.50 & orange & 26.5 & 14.72 & 63.38 & 48.66 & 8.48 & 18.19 & 9.71 \\
\hline A4B-EDI-CP & 20 & 25 & 0.09 & 3/19/12 17:55 & 3/19/12 18:55 & 1.40 & orange red & 25.1 & 8.47 & 13.20 & 4.73 & NA & NA & NA \\
\hline A4B-RG-CP & 20 & 25 & 0.09 & 3/19/12 19:05 & 3/19/12 22:05 & 1.50 & dark red & 24.8 & 8.43 & 23.39 & 14.96 & NA & NA & NA \\
\hline
\end{tabular}


Table A.10. Datasheet for Column A5 Loading and Rinsing Information

\begin{tabular}{|c|c|c|c|c|c|c|c|c|c|c|c|c|c|c|}
\hline \multirow{2}{*}{$\begin{array}{l}\text { Sample } \\
\text { ID No. }\end{array}$} & \multirow{2}{*}{$\begin{array}{c}\text { Bottle } \\
\text { Size } \\
(\mathrm{mL})\end{array}$} & \multirow{2}{*}{$\begin{array}{c}\text { Temp } \\
\text { Set } \\
\left({ }^{\circ} \mathrm{C}\right)\end{array}$} & \multirow{2}{*}{$\begin{array}{c}\text { Pump } \\
\begin{array}{c}\text { Setting } \\
(\mathrm{mL} / \mathrm{min})\end{array}\end{array}$} & \multirow{2}{*}{$\begin{array}{l}\text { Sampling } \\
\text { Start Time }\end{array}$} & \multirow{2}{*}{$\begin{array}{l}\text { Sampling } \\
\text { Stop Time }\end{array}$} & \multirow{2}{*}{$\begin{array}{c}\text { Resin } \\
\begin{array}{c}\text { Height } \\
(\mathrm{cm})\end{array}\end{array}$} & \multirow{2}{*}{$\begin{array}{l}\text { Resin } \\
\text { Color }\end{array}$} & \multirow{2}{*}{$\begin{array}{l}\text { Temp } \\
\left({ }^{\circ} \mathrm{C}\right)\end{array}$} & \multicolumn{3}{|c|}{ Effluent Bottle Weight, g } & \multicolumn{3}{|c|}{ Sample Vial Weight, g } \\
\hline & & & & & & & & & Tare & Gross & Net & Tare & Gross & Net \\
\hline A5-LD-0 & 20 & 45 & NA & $3 / 20 / 126: 41$ & $3 / 20 / 126: 41$ & 1.50 & dark red & 50.6 & NA & NA & NA & 8.47 & 12.89 & 4.42 \\
\hline \multicolumn{4}{|c|}{ Loading (LD) Phase Start Date/Time: } & 3/20/12 6:45 & & & & & & & & & & \\
\hline A5-LD-006 & 20 & 45 & 10.62 & 3/20/12 6:51 & 3/20/12 6:51 & NA & dark red & 46.6 & NA & NA & NA & 8.43 & 12.62 & 4.19 \\
\hline A5-LD-012 & 20 & 45 & 10.62 & 3/20/12 6:57 & 3/20/12 6:57 & NA & dark red & 44.6 & NA & NA & NA & 8.41 & 12.72 & 4.31 \\
\hline A5-LD-018 & 20 & 45 & 10.62 & 3/20/12 7:03 & 3/20/12 7:03 & NA & dark red & 43.8 & NA & NA & NA & 8.44 & 13.00 & 4.56 \\
\hline A5-LD-024 & 20 & 45 & 10.62 & 3/20/12 7:09 & 3/20/12 7:09 & NA & dark red & 43.6 & NA & NA & NA & 8.52 & 12.89 & 4.37 \\
\hline A5-LD-036 & 20 & 45 & 10.62 & $3 / 20 / 127: 21$ & $3 / 20 / 127: 21$ & NA & dark red & 43.9 & NA & NA & NA & 8.50 & 13.01 & 4.51 \\
\hline A5-LD-048 & 20 & 45 & 10.62 & 3/20/12 7:33 & 3/20/12 7:33 & NA & dark red & 44.4 & NA & NA & NA & 8.48 & 12.89 & 4.41 \\
\hline A5-LD-060 & 20 & 45 & 10.62 & 3/20/12 7:45 & $3 / 20 / 127: 45$ & NA & dark red & 44.8 & NA & NA & NA & 8.49 & 12.93 & 4.44 \\
\hline A5-LD-080 & 20 & 45 & 10.62 & 3/20/12 8:05 & 3/20/12 8:05 & NA & dark red & 45.0 & NA & NA & NA & 8.47 & 12.89 & 4.42 \\
\hline A5-LD-120 & 20 & 45 & 10.62 & 3/20/12 8:45 & 3/20/12 8:45 & NA & dark red & 45.0 & NA & NA & NA & 8.58 & 12.98 & 4.40 \\
\hline A5-LD-180 & 20 & 45 & 10.62 & 3/20/12 9:45 & 3/20/12 9:45 & NA & dark red & 45.0 & NA & NA & NA & 8.44 & 12.85 & 4.41 \\
\hline A5-LD-240 & 20 & 45 & 10.62 & 3/20/12 10:45 & 3/20/12 10:45 & NA & dark red & 45.0 & NA & NA & NA & 8.38 & 12.74 & 4.36 \\
\hline A5-LD-600 & 20 & 45 & 10.62 & 3/20/12 16:45 & 3/20/12 16:45 & NA & dark red & 44.8 & NA & NA & NA & 8.29 & 12.51 & 4.22 \\
\hline A5-FD-CP & 20 & 45 & 0.09 & $3 / 20 / 12$ 16:56 & 3/20/12 19:26 & 1.50 & dark red & 45.0 & 8.38 & 22.71 & 14.33 & NA & NA & NA \\
\hline A5-FDI-CP & 20 & 25 & 0.09 & 3/20/12 19:58 & 3/20/12 22:28 & 1.50 & dark red & 25.5 & 8.47 & 21.27 & 12.80 & NA & NA & NA \\
\hline A5-AN-CP & 20 & 25 & 0.09 & 3/20/12 22:31 & 3/20/12 23:31 & 1.50 & dark red & 24.8 & 8.48 & 13.54 & 5.06 & NA & NA & NA \\
\hline
\end{tabular}

Table A.11. Datasheet for Column A5 Elution, Rinsing, and Regeneration Information

\begin{tabular}{|c|c|c|c|c|c|c|c|c|c|c|c|c|c|c|}
\hline \multirow{2}{*}{$\begin{array}{l}\text { Sample } \\
\text { ID No. }\end{array}$} & \multirow{2}{*}{$\begin{array}{c}\text { Bottle } \\
\text { Size } \\
(\mathrm{mL})\end{array}$} & \multirow{2}{*}{$\begin{array}{c}\text { Temp } \\
\text { Set } \\
\left({ }^{\circ} \mathrm{C}\right)\end{array}$} & \multirow{2}{*}{$\begin{array}{c}\text { Pump } \\
\begin{array}{c}\text { Setting } \\
(\mathrm{mL} / \mathrm{min})\end{array}\end{array}$} & \multirow{2}{*}{$\begin{array}{l}\text { Sampling } \\
\text { Start Time }\end{array}$} & \multirow{2}{*}{$\begin{array}{l}\text { Sampling } \\
\text { Stop Time }\end{array}$} & \multirow{2}{*}{$\begin{array}{c}\text { Resin } \\
\begin{array}{c}\text { Height } \\
(\mathrm{cm})\end{array}\end{array}$} & \multirow{2}{*}{$\begin{array}{l}\text { Resin } \\
\text { Color }\end{array}$} & \multirow{2}{*}{$\begin{array}{l}\text { Temp } \\
\left({ }^{\circ} \mathrm{C}\right)\end{array}$} & \multicolumn{3}{|c|}{ Effluent Bottle Weight, g } & \multicolumn{3}{|c|}{ Sample Vial Weight, g } \\
\hline & & & & & & & & & Tare & Gross & Net & Tare & Gross & Net \\
\hline Elutic & on (EL) & hase Sta & Date/Time: & $3 / 21 / 126: 40$ & & & & & & & & & & \\
\hline A5-EL-CP & 60 & 25 & 0.08 & $3 / 21 / 126: 40$ & 3/21/12 17:40 & 1.45 & orange & 26.0 & 14.64 & 63.21 & 48.57 & 8.43 & 14.59 & 6.16 \\
\hline A5-EDI-CP & 20 & 25 & 0.09 & 3/21/12 17:47 & 3/21/12 18:47 & 1.45 & orange & 25.7 & 8.50 & 13.22 & 4.72 & NA & NA & NA \\
\hline
\end{tabular}


Table A.12. Datasheet for Column B1 Pretreatment, Loading, and Rinsing Information

\begin{tabular}{|c|c|c|c|c|c|c|c|c|c|c|c|c|c|c|}
\hline Sample & Bottle & Temp & Pump & Sampling & Sampling & Resin & Resin & Temp & \multicolumn{3}{|c|}{ Effluent Bottle Weight, g } & \multicolumn{3}{|c|}{ Sample Vial Weight, g } \\
\hline ID No. & $\begin{array}{l}\text { Size } \\
(\mathrm{mL})\end{array}$ & $\begin{array}{l}\text { Set } \\
\left({ }^{\circ} \mathrm{C}\right)\end{array}$ & $\begin{array}{l}\text { Setting } \\
\text { (mL/min) }\end{array}$ & Start Time & Stop Time & $\begin{array}{l}\text { Height } \\
\text { (cm) }\end{array}$ & Color & $\left({ }^{\circ} \mathrm{C}\right)$ & Tare & Gross & Net & Tare & Gross & Net \\
\hline B1-PT-DIW1 & 20 & 25 & 0.09 & 2/5/12 14:05 & 2/5/12 17:20 & 1.15 & dark red & 24.5 & 8.44 & 25.21 & 16.77 & NA & NA & NA \\
\hline B1-PT-ACID & 20 & 25 & 0.09 & 2/6/12 9:16 & 2/6/12 12:16 & 1.10 & orange & 24.9 & 8.44 & 22.86 & 14.42 & NA & NA & NA \\
\hline B1-PT-DIW2 & 20 & 25 & 0.09 & 2/6/12 13:00 & 2/6/12 14:00 & 1.00 & orange & 23.9 & 8.33 & 13.18 & 4.85 & NA & NA & NA \\
\hline B1-PT-NaOH & 20 & 25 & 0.09 & 2/6/12 14:10 & 2/6/12 16:30 & 1.30 & dark red & 24.3 & 8.50 & 20.33 & 11.83 & NA & NA & NA \\
\hline B1-LD-0 & 20 & 50.1 & NA & 2/13/12 6:50 & 2/13/12 6:50 & 1.30 & dark red & 50.1 & NA & NA & NA & 8.49 & 14.41 & 5.92 \\
\hline \multicolumn{4}{|c|}{ Loading (LD) Phase Start Date/Time: } & 2/13/12 6:55 & & & & & & & & & & \\
\hline B1-LD-006 & 20 & 40 & 10.62 & 2/13/12 7:01 & 2/13/12 7:01 & NA & dark red & 45.9 & NA & NA & NA & 8.38 & 12.64 & 4.26 \\
\hline B1-LD-012 & 20 & 40 & 10.62 & 2/13/12 7:07 & 2/13/12 7:07 & NA & dark red & 43.7 & NA & NA & NA & 8.41 & 12.74 & 4.33 \\
\hline B1-LD-018 & 20 & 40 & 10.62 & 2/13/12 7:13 & 2/13/12 7:13 & NA & dark red & 42.1 & NA & NA & NA & 8.43 & 12.50 & 4.07 \\
\hline B1-LD-024 & 20 & 40 & 10.62 & 2/13/12 7:19 & 2/13/12 7:19 & NA & dark red & 41.0 & NA & NA & NA & 8.53 & 12.69 & 4.16 \\
\hline B1-LD-036 & 20 & 40 & 10.62 & 2/13/12 7:31 & 2/13/12 7:31 & NA & dark red & 39.8 & NA & NA & NA & 8.41 & 12.58 & 4.17 \\
\hline B1-LD-048 & 20 & 40 & 10.62 & 2/13/12 7:43 & 2/13/12 7:43 & NA & dark red & 39.3 & NA & NA & NA & 8.43 & 12.66 & 4.23 \\
\hline B1-LD-060 & 20 & 40 & 10.62 & 2/13/12 7:55 & 2/13/12 7:55 & NA & dark red & 39.5 & NA & NA & NA & 8.40 & 12.49 & 4.09 \\
\hline B1-LD-080 & 20 & 40 & 10.62 & 2/13/12 8:15 & 2/13/12 8:15 & NA & dark red & 39.8 & NA & NA & NA & 8.45 & 12.65 & 4.20 \\
\hline B1-LD-120 & 20 & 40 & 10.62 & 2/13/12 8:55 & 2/13/12 8:55 & NA & dark red & 39.8 & NA & NA & NA & 8.51 & 12.03 & 3.52 \\
\hline B1-LD-180 & 20 & 40 & 10.62 & 2/13/12 9:55 & 2/13/12 9:55 & NA & dark red & 39.9 & NA & NA & NA & 8.44 & 12.31 & 3.87 \\
\hline B1-LD-240 & 20 & 40 & 10.62 & 2/13/12 10:55 & 2/13/12 10:55 & NA & dark red & 39.8 & NA & NA & NA & 8.58 & 13.05 & 4.47 \\
\hline B1-LD-600 & 20 & 40 & 10.62 & 2/13/12 16:55 & 2/13/12 16:55 & NA & dark red & 40.1 & NA & NA & NA & 8.59 & 12.98 & 4.39 \\
\hline B1-FD-CP & 20 & 40 & 0.09 & 2/13/12 17:12 & 2/13/12 19:42 & NA & dark red & 39.2 & 8.56 & 23.34 & 14.78 & NA & NA & NA \\
\hline B1-FDI-CP & 20 & 25 & 0.09 & 2/13/12 20:07 & 2/13/12 22:37 & 1.30 & dark red & 24.9 & 8.54 & 21.63 & 13.09 & NA & NA & NA \\
\hline B1-AN-CP & 20 & 25 & 0.09 & 2/13/12 22:41 & 2/13/12 23:41 & 1.30 & dark red & 24.1 & 8.45 & 13.26 & 4.81 & NA & NA & NA \\
\hline
\end{tabular}


Table A.13. Datasheet for Column B1 Elution, Rinsing, and Regeneration Information

\begin{tabular}{|c|c|c|c|c|c|c|c|c|c|c|c|c|c|c|}
\hline \multirow{2}{*}{$\begin{array}{l}\text { Sample } \\
\text { ID No. }\end{array}$} & \multirow{2}{*}{$\begin{array}{c}\text { Bottle } \\
\text { Size } \\
(\mathrm{mL})\end{array}$} & \multirow{2}{*}{$\begin{array}{c}\text { Temp } \\
\text { Set } \\
\left({ }^{\circ} \mathrm{C}\right)\end{array}$} & \multirow{2}{*}{$\begin{array}{c}\text { Pump } \\
\begin{array}{c}\text { Setting } \\
(\mathrm{mL} / \mathrm{min})\end{array}\end{array}$} & \multirow{2}{*}{$\begin{array}{l}\text { Sampling } \\
\text { Start Time }\end{array}$} & \multirow{2}{*}{$\begin{array}{l}\text { Sampling } \\
\text { Stop Time }\end{array}$} & \multirow{2}{*}{$\begin{array}{c}\text { Resin } \\
\begin{array}{c}\text { Height } \\
(\mathrm{cm})\end{array}\end{array}$} & \multirow{2}{*}{$\frac{\text { Resin }}{\text { Color }}$} & \multirow{2}{*}{$\begin{array}{c}\text { Temp } \\
\left({ }^{\circ} \mathrm{C}\right)\end{array}$} & \multicolumn{3}{|c|}{ Effluent Bottle Weight, g } & \multicolumn{3}{|c|}{ Sample Vial Weight, g } \\
\hline & & & & & & & & & Tare & Gross & Net & Tare & Gross & Net \\
\hline Elut & on (EL) & hase Sta & Date/Time: & 2/14/12 6:50 & & & & & & & & & & \\
\hline B1-EL-CP & 60 & 25 & 0.08 & $2 / 14 / 126: 50$ & 2/14/12 16:50 & 1.15 & orange & 24.6 & 14.88 & 64.86 & 49.98 & 8.42 & 18.91 & 10.49 \\
\hline B1-EDI-CP & 20 & 25 & 0.09 & 2/14/12 17:12 & 2/14/12 18:12 & 1.15 & orange & 24.2 & 8.41 & 13.57 & 5.16 & NA & NA & NA \\
\hline B1-RG-CP & 20 & 25 & 0.09 & 2/14/12 18:17 & 2/14/12 20:47 & 1.30 & $\begin{array}{l}\text { dark } \\
\text { red }\end{array}$ & 25.3 & 8.62 & 12.21 & $\begin{array}{c}3.59 \text { (vial } \\
\text { spilled) }\end{array}$ & NA & NA & NA \\
\hline
\end{tabular}

Table A.14. Datasheet for Column B2 Loading and Rinsing Information

\begin{tabular}{|c|c|c|c|c|c|c|c|c|c|c|c|c|c|c|}
\hline Sample & Bottle & Temp & Pump & Sampling & Sampling & Resin & Resin & Temp & Efflu & Bottle & eight, $g$ & Sam & Vial W & ht, g \\
\hline ID No. & $\begin{array}{l}\text { Size } \\
(\mathrm{mL})\end{array}$ & $\begin{array}{l}\text { Set } \\
\left({ }^{\circ} \mathrm{C}\right)\end{array}$ & $\begin{array}{l}\text { Setting } \\
(\mathrm{mL} / \mathrm{min})\end{array}$ & Start Time & Stop Time & $\begin{array}{l}\text { Height } \\
(\mathrm{cm})\end{array}$ & Color & $\left({ }^{\circ} \mathrm{C}\right)$ & Tare & Gross & Net & Tare & Gross & Net \\
\hline B2-LD-0 & 20 & 40 & NA & 2/15/12 6:49 & $2 / 15 / 126: 49$ & 1.30 & dark red & 50.0 & NA & NA & NA & 8.47 & 12.71 & 4.24 \\
\hline Loadi & $\lg (\mathrm{LD})$ & hase Sta & Date/Time: & 2/15/12 6:53 & & & & & & & & & & \\
\hline B2-LD-006 & 20 & 40 & 14.16 & 2/15/12 6:59 & 2/15/12 6:59 & NA & dark red & 45.3 & NA & NA & NA & 8.90 & 13.04 & 4.14 \\
\hline B2-LD-012 & 20 & 40 & 14.16 & 2/15/12 7:05 & 2/15/12 7:05 & NA & dark red & 43.0 & NA & NA & NA & 8.65 & 13.07 & 4.42 \\
\hline B2-LD-018 & 20 & 40 & 14.16 & 2/15/12 7:11 & 2/15/12 7:11 & NA & dark red & 41.5 & NA & NA & NA & 8.48 & 12.85 & 4.37 \\
\hline B2-LD-024 & 20 & 40 & 14.16 & 2/15/12 7:17 & 2/15/12 7:17 & NA & dark red & 40.3 & NA & NA & NA & 8.90 & 13.40 & 4.50 \\
\hline B2-LD-036 & 20 & 40 & 14.16 & 2/15/12 7:29 & 2/15/12 7:29 & NA & dark red & 39.0 & NA & NA & NA & 8.64 & 13.09 & 4.45 \\
\hline B2-LD-048 & 20 & 40 & 14.16 & 2/15/12 7:41 & 2/15/12 7:41 & NA & dark red & 38.8 & NA & NA & NA & 8.56 & 13.01 & 4.45 \\
\hline B2-LD-060 & 20 & 40 & 14.16 & 2/15/12 7:53 & 2/15/12 7:53 & NA & dark red & 39.0 & NA & NA & NA & 8.60 & 12.59 & 3.99 \\
\hline B2-LD-080 & 20 & 40 & 14.16 & 2/15/12 8:13 & 2/15/12 8:13 & NA & dark red & 39.2 & NA & NA & NA & 8.64 & 12.97 & 4.33 \\
\hline B2-LD-120 & 20 & 40 & 14.16 & 2/15/12 8:53 & 2/15/12 8:53 & NA & dark red & 39.4 & NA & NA & NA & 8.62 & 12.90 & 4.28 \\
\hline B2-LD-180 & 20 & 40 & 14.16 & 2/15/12 9:53 & 2/15/12 9:53 & NA & dark red & 39.6 & NA & NA & NA & 8.56 & 13.08 & 4.52 \\
\hline B2-LD-240 & 20 & 40 & 14.16 & $2 / 15 / 12$ 10:53 & $2 / 15 / 12$ 10:53 & NA & dark red & 39.3 & NA & NA & NA & 8.62 & 13.21 & 4.59 \\
\hline B2-LD-600 & 20 & 40 & 14.16 & $2 / 15 / 12$ 16:53 & 2/15/12 16:53 & NA & dark red & 39.9 & NA & NA & NA & 8.58 & 12.95 & 4.37 \\
\hline B2-FD-CP & 20 & 40 & 0.09 & 2/15/12 17:07 & 2/15/12 19:37 & 1.30 & dark red & 40.4 & 8.58 & 23.44 & 14.86 & NA & NA & NA \\
\hline B2-FDI-CP & 20 & 25 & 0.09 & 2/15/12 19:50 & 2/15/12 22:20 & 1.30 & dark red & 24.8 & 8.69 & 22.10 & 13.41 & NA & NA & NA \\
\hline B2-AN-CP & 20 & 25 & 0.09 & 2/15/12 22:25 & 2/15/12 23:25 & 1.30 & dark red & 24.9 & 8.64 & 13.79 & 5.15 & NA & NA & NA \\
\hline
\end{tabular}


Table A.15. Datasheet for Column B2 Elution, Rinsing, and Regeneration Information

\begin{tabular}{|c|c|c|c|c|c|c|c|c|c|c|c|c|c|c|}
\hline Sample & Bottle & Temp & Pump & Sampling & Sampling & Resin & Resin & Temp & \multicolumn{3}{|c|}{ Effluent Bottle Weight, g } & \multicolumn{3}{|c|}{ Sample Vial Weight, g } \\
\hline ID No. & $\begin{array}{l}\text { Size } \\
(\mathrm{mL})\end{array}$ & $\begin{array}{l}\text { Set } \\
\left({ }^{\circ} \mathrm{C}\right) \\
\end{array}$ & $\begin{array}{c}\text { Setting } \\
(\mathrm{mL} / \mathrm{min})\end{array}$ & Start Time & Stop Time & $\begin{array}{c}\text { Height } \\
(\mathrm{cm})\end{array}$ & Color & $\left({ }^{\circ} \mathrm{C}\right)$ & Tare & Gross & Net & Tare & Gross & Net \\
\hline \multicolumn{4}{|c|}{ Elution (EL) Phase Start Date/Time: } & $2 / 16 / 126: 44$ & & & & & & & & & & \\
\hline B2-EL-CP & 60 & 25 & 0.08 & 2/16/12 6:44 & 2/16/12 17:14 & 1.15 & orange & 25.0 & 14.91 & 64.54 & 49.63 & 8.51 & 18.15 & 9.64 \\
\hline B2-EDI-CP & 20 & 25 & 0.09 & 2/16/12 17:27 & 2/16/12 18:27 & 1.15 & orange & 24.3 & 8.65 & 13.90 & 5.25 & NA & NA & NA \\
\hline B2-RG-CP & 20 & 25 & 0.09 & 2/16/12 18:33 & 2/16/12 21:03 & 1.30 & dark red & 24.9 & 8.67 & 21.59 & 12.92 & NA & NA & NA \\
\hline
\end{tabular}

Table A.16. Datasheet for Column B3 Loading and Rinsing Information

\begin{tabular}{|c|c|c|c|c|c|c|c|c|c|c|c|c|c|c|}
\hline Sample & Bottle & Temp & Pump & Sampling & Sampling & Resin & Resin & Temp & \multicolumn{3}{|c|}{ Effluent Bottle Weight, g } & \multicolumn{3}{|c|}{ Sample Vial Weight, g } \\
\hline ID No. & $\begin{array}{l}\text { Size } \\
(\mathrm{mL})\end{array}$ & $\begin{array}{l}\text { Set } \\
\left({ }^{\circ} \mathrm{C}\right)\end{array}$ & $\begin{array}{c}\text { Setting } \\
\text { (mL/min) }\end{array}$ & Start Time & Stop Time & $\begin{array}{l}\text { Height } \\
\text { (cm) }\end{array}$ & Color & $\left({ }^{\circ} \mathrm{C}\right)$ & Tare & Gross & Net & Tare & Gross & Net \\
\hline B3-LD-0 & 20 & 40 & NA & 2/21/12 6:53 & 2/21/12 6:53 & 1.30 & dark red & 49.1 & NA & NA & NA & 8.61 & 12.76 & 4.15 \\
\hline \multicolumn{2}{|c|}{ Loading (LD) } & hase Sta & Date/Time: & 2/21/12 6:58 & & & & & & & & & & \\
\hline B3-LD-006 & 20 & 40 & 7.08 & 2/21/12 7:04 & 2/21/12 7:04 & NA & dark red & 45.9 & NA & NA & NA & 8.58 & 13.01 & 4.43 \\
\hline B3-LD-012 & 20 & 40 & 7.08 & 2/21/12 7:10 & 2/21/12 7:10 & NA & dark red & 44.0 & NA & NA & NA & 8.50 & 13.02 & 4.52 \\
\hline B3-LD-018 & 20 & 40 & 7.08 & 2/21/12 7:16 & 2/21/12 7:16 & NA & dark red & 42.6 & NA & NA & NA & 8.62 & 13.09 & 4.47 \\
\hline B3-LD-024 & 20 & 40 & 7.08 & 2/21/12 7:22 & 2/21/12 7:22 & NA & dark red & 41.7 & NA & NA & NA & 8.52 & 13.00 & 4.48 \\
\hline B3-LD-036 & 20 & 40 & 7.08 & 2/21/12 7:34 & 2/21/12 7:34 & NA & dark red & 40.5 & NA & NA & NA & 8.41 & 12.90 & 4.49 \\
\hline B3-LD-048 & 20 & 40 & 7.08 & 2/21/12 7:46 & 2/21/12 7:46 & NA & dark red & 40.0 & NA & NA & NA & 8.51 & 12.94 & 4.43 \\
\hline B3-LD-060 & 20 & 40 & 7.08 & 2/21/12 7:58 & 2/21/12 7:58 & NA & dark red & 39.7 & NA & NA & NA & 8.62 & 13.17 & 4.55 \\
\hline B3-LD-080 & 20 & 40 & 7.08 & 2/21/12 8:18 & 2/21/12 8:18 & NA & dark red & 39.7 & NA & NA & NA & 8.83 & 13.12 & 4.29 \\
\hline B3-LD-120 & 20 & 40 & 7.08 & 2/21/12 8:58 & 2/21/12 8:58 & NA & dark red & 39.8 & NA & NA & NA & 8.50 & 13.00 & 4.50 \\
\hline B3-LD-180 & 20 & 50 & 7.08 & 2/21/12 9:58 & 2/21/12 9:58 & NA & dark red & 40.0 & NA & NA & NA & 8.46 & 13.00 & 4.54 \\
\hline B3-LD-240 & 20 & 50 & 7.08 & 2/21/12 10:58 & 2/21/12 10:58 & NA & dark red & 39.9 & NA & NA & NA & 8.63 & 12.97 & 4.34 \\
\hline B3-LD-600 & 20 & 50 & 7.08 & 2/21/12 16:58 & 2/21/12 16:58 & NA & dark red & 39.9 & NA & NA & NA & 8.54 & 12.82 & 4.28 \\
\hline B3-FD-CP & 20 & 50 & 0.09 & 2/21/12 17:08 & 2/21/12 19:38 & NA & dark red & 39.8 & 8.60 & 23.32 & 14.72 & NA & NA & NA \\
\hline B3-FDI-CP & 20 & 25 & 0.09 & 2/21/12 19:45 & 2/21/12 22:15 & NA & dark red & 25.1 & 8.48 & 21.88 & 13.40 & NA & NA & NA \\
\hline B3-AN-CP & 20 & 25 & 0.09 & 2/21/12 22:22 & 2/21/12 23:17 & NA & dark red & 24.9 & 8.83 & 13.69 & 4.86 & NA & NA & NA \\
\hline
\end{tabular}


Table A.17. Datasheet for Column B3 Elution, Rinsing, and Regeneration Information

\begin{tabular}{|c|c|c|c|c|c|c|c|c|c|c|c|c|c|c|}
\hline Sample & Bottle & Temp & Pump & Sampling & Sampling & Resin & Resin & Temp & \multicolumn{3}{|c|}{ Effluent Bottle Weight, g } & \multicolumn{3}{|c|}{ Sample Vial Weight, g } \\
\hline ID No. & $\begin{array}{l}\text { Size } \\
(\mathrm{mL})\end{array}$ & $\begin{array}{l}\text { Set } \\
\left({ }^{\circ} \mathrm{C}\right)\end{array}$ & $\begin{array}{c}\text { Setting } \\
(\mathrm{mL} / \mathrm{min})\end{array}$ & Start Time & Stop Time & $\begin{array}{l}\text { Height } \\
(\mathrm{cm})\end{array}$ & Color & $\left({ }^{\circ} \mathrm{C}\right)$ & Tare & Gross & Net & Tare & Gross & Net \\
\hline \multicolumn{4}{|c|}{ Elution (EL) } & $2 / 22 / 126: 47$ & & & & & & & & & & \\
\hline B3-EL-CP & 60 & 25 & 0.08 & 2/22/12 6:47 & $2 / 22 / 1216: 50$ & 1.25 & orange red & 25.6 & 14.66 & 62.18 & 47.52 & 8.56 & 18.05 & 9.49 \\
\hline B3-EDI-CP & 20 & 25 & 0.09 & 2/22/12 17:01 & 2/22/12 18:01 & 1.25 & orange red & 24.3 & 8.52 & 13.73 & 5.21 & NA & NA & NA \\
\hline B3-RG-CP & 20 & 25 & 0.09 & 2/22/12 18:07 & 2/22/12 20:47 & 1.30 & dark red & 25.3 & 8.52 & 22.48 & 13.96 & NA & NA & NA \\
\hline
\end{tabular}

Table A.18. Datasheet for Column B4 Loading and Rinsing Information

\begin{tabular}{|c|c|c|c|c|c|c|c|c|c|c|c|c|c|c|}
\hline Sample & Bottle & Temp & Pump & Sampling & Sampling & Resin & Resin & Temp & \multicolumn{3}{|c|}{ Effluent Bottle Weight, g } & \multicolumn{3}{|c|}{ Sample Vial Weight, g } \\
\hline ID No. & $\begin{array}{l}\text { Size } \\
(\mathrm{mL})\end{array}$ & $\begin{array}{l}\text { Set } \\
\left({ }^{\circ} \mathrm{C}\right)\end{array}$ & $\begin{array}{l}\text { Setting } \\
\text { (mL/min) }\end{array}$ & Start Time & Stop Time & $\begin{array}{l}\text { Height } \\
\text { (cm) }\end{array}$ & Color & $\left({ }^{\circ} \mathrm{C}\right)$ & Tare & Gross & Net & Tare & Gross & Net \\
\hline B4-LD-0 & 20 & 40 & NA & $2 / 23 / 126: 48$ & $2 / 23 / 126: 48$ & 1.30 & dark red & 46.0 & NA & NA & NA & 8.66 & 13.14 & 4.48 \\
\hline \multicolumn{4}{|c|}{ Loading (LD) Phase Start Date/Time: } & 2/23/12 6:53 & & & & & & & & & & \\
\hline B4-LD-006 & 20 & 40 & 10.62 & 2/23/12 6:59 & 2/23/12 6:59 & NA & dark red & 42.6 & NA & NA & NA & 8.64 & 13.11 & 4.47 \\
\hline B4-LD-012 & 20 & 40 & 10.62 & 2/23/12 7:05 & 2/23/12 7:05 & NA & dark red & 41.0 & NA & NA & NA & 8.58 & 13.04 & 4.46 \\
\hline B4-LD-018 & 20 & 40 & 10.62 & 2/23/12 7:11 & 2/23/12 7:11 & NA & dark red & 40.0 & NA & NA & NA & 8.61 & 13.14 & 4.53 \\
\hline B4-LD-024 & 20 & 40 & 10.62 & 2/23/12 7:17 & 2/23/12 7:17 & NA & dark red & 39.6 & NA & NA & NA & 8.73 & 13.18 & 4.45 \\
\hline B4-LD-036 & 20 & 40 & 10.62 & 2/23/12 7:29 & 2/23/12 7:29 & NA & dark red & 40.2 & NA & NA & NA & 8.69 & 12.98 & 4.29 \\
\hline B4-LD-048 & 20 & 40 & 10.62 & 2/23/12 7:41 & 2/23/12 7:41 & NA & dark red & 40.1 & NA & NA & NA & 8.51 & 13.06 & 4.55 \\
\hline B4-LD-060 & 20 & 40 & 10.62 & 2/23/12 7:53 & 2/23/12 7:53 & NA & dark red & 39.8 & NA & NA & NA & 8.57 & 13.10 & 4.53 \\
\hline B4-LD-080 & 20 & 40 & 10.62 & 2/23/12 8:13 & 2/23/12 8:13 & NA & dark red & 39.6 & NA & NA & NA & 8.52 & 13.00 & 4.48 \\
\hline B4-LD-120 & 20 & 40 & 10.62 & 2/23/12 8:53 & 2/23/12 8:53 & NA & dark red & 39.7 & NA & NA & NA & 8.51 & 12.91 & 4.40 \\
\hline B4-LD-180 & 20 & 40 & 10.62 & 2/23/12 9:53 & 2/23/12 9:53 & NA & dark red & 39.8 & NA & NA & NA & 8.67 & 13.21 & 4.54 \\
\hline B4-LD-240 & 20 & 40 & 10.62 & 2/23/12 10:53 & 2/23/12 10:53 & NA & dark red & 39.5 & NA & NA & NA & 8.44 & 12.81 & 4.37 \\
\hline B4-LD-600 & 20 & 40 & 10.62 & 2/23/12 16:53 & 2/23/12 16:53 & NA & dark red & 40.0 & NA & NA & NA & 8.62 & 12.92 & 4.30 \\
\hline B4-FD-CP & 20 & 40 & 0.09 & 2/23/12 17:06 & 2/23/12 19:36 & NA & dark red & 40.8 & 8.48 & 23.10 & 14.62 & NA & NA & NA \\
\hline B4-FDI-CP & 20 & 25 & 0.09 & 2/23/12 19:54 & 2/23/12 21:54 & NA & dark red & 25.0 & 8.53 & 20.52 & 11.99 & NA & NA & NA \\
\hline
\end{tabular}


Table A.19. Datasheet for Column B4B Loading and Rinsing Information

\begin{tabular}{|c|c|c|c|c|c|c|c|c|c|c|c|c|c|c|}
\hline \multirow{2}{*}{$\begin{array}{l}\text { Sample } \\
\text { ID No. }\end{array}$} & \multirow{2}{*}{$\begin{array}{c}\text { Bottle } \\
\text { Size } \\
(\mathrm{mL})\end{array}$} & \multirow{2}{*}{$\begin{array}{c}\text { Temp } \\
\text { Set } \\
\left({ }^{\circ} \mathrm{C}\right)\end{array}$} & \multirow{2}{*}{$\begin{array}{c}\text { Pump } \\
\begin{array}{c}\text { Setting } \\
(\mathrm{mL} / \mathrm{min})\end{array}\end{array}$} & \multirow{2}{*}{$\begin{array}{l}\text { Sampling } \\
\text { Start Time }\end{array}$} & \multirow{2}{*}{$\begin{array}{l}\text { Sampling } \\
\text { Stop Time }\end{array}$} & \multirow{2}{*}{$\begin{array}{l}\text { Resin } \\
\begin{array}{c}\text { Height } \\
(\mathrm{cm})\end{array}\end{array}$} & \multirow{2}{*}{$\begin{array}{l}\text { Resin } \\
\text { Color }\end{array}$} & \multirow{2}{*}{$\begin{array}{l}\text { Temp } \\
\left({ }^{\circ} \mathrm{C}\right)\end{array}$} & \multicolumn{3}{|c|}{ Effluent Bottle Weight, g } & \multicolumn{3}{|c|}{ Sample Vial Weight, g } \\
\hline & & & & & & & & & Tare & Gross & Net & Tare & Gross & Net \\
\hline B4B-LD-0 & 20 & 55 & NA & 2/29/12 9:00 & 2/29/12 9:00 & 1.30 & dark red & 34.8 & NA & NA & NA & 8.44 & 12.93 & 4.49 \\
\hline \multicolumn{4}{|c|}{ Loading (LD) Phase Start Date/Time: } & 2/29/12 9:03 & & & & & & & & & & \\
\hline B4B-LD-004 & 20 & 55 & 0.08 & 2/29/12 13:03 & 2/29/12 13:03 & NA & dark red & 54.9 & NA & NA & NA & 8.43 & 12.79 & 4.36 \\
\hline B4B-LD-008 & 20 & 55 & 0.08 & 2/29/12 17:03 & 2/29/12 17:03 & NA & dark red & 55.0 & NA & NA & NA & 8.52 & 12.96 & 4.44 \\
\hline B4B-LD-012 & 20 & 55 & 0.08 & 2/29/12 21:03 & 2/29/12 21:03 & NA & dark red & 55.1 & NA & NA & NA & 8.40 & 12.48 & 4.08 \\
\hline B4B-LD-024 & 20 & 55 & 0.08 & 3/1/12 9:03 & 3/1/12 9:03 & NA & dark red & 55.2 & NA & NA & NA & 8.46 & 12.61 & 4.15 \\
\hline B4B-LD-072 & 20 & 55 & 0.08 & 3/3/12 9:03 & 3/3/12 9:03 & NA & dark red & 55.0 & NA & NA & NA & 8.47 & 13.15 & 4.68 \\
\hline B4B-LD-120 & 20 & 55 & 0.08 & 3/5/12 9:03 & 3/5/12 9:03 & NA & dark red & 54.9 & NA & NA & NA & 8.36 & 12.65 & 4.29 \\
\hline B4B-LD-168 & 20 & 55 & 0.08 & 3/7/12 9:03 & 3/7/12 9:03 & NA & dark red & 54.6 & NA & NA & NA & 8.48 & 12.82 & 4.34 \\
\hline B4B-LD-336 & 20 & 55 & 0.08 & 3/14/12 9:03 & 3/14/12 9:03 & NA & dark red & 55.6 & NA & NA & NA & 8.48 & 13.26 & 4.78 \\
\hline B4B-FD-CP & 20 & 55 & 0.08 & 3/18/12 9:20 & 3/18/12 11:50 & NA & dark red & 54.8 & 8.29 & 19.34 & 11.05 & NA & NA & NA \\
\hline B4B-FDI-CP & 20 & 25 & 0.09 & 3/18/12 12:10 & 3/18/12 14:42 & NA & dark red & 25.4 & 8.38 & 21.79 & 13.41 & NA & NA & NA \\
\hline B4B-AN-CP & 20 & 25 & 0.09 & 3/18/12 14:52 & 3/18/12 15:53 & 1.45 & dark red & 25.8 & 8.40 & 13.78 & 5.38 & NA & NA & NA \\
\hline
\end{tabular}

Table A.20. Datasheet for Column B4B Elution, Rinsing, and Regeneration Information

\begin{tabular}{|c|c|c|c|c|c|c|c|c|c|c|c|c|c|c|}
\hline Sample & Bottle & Temp & Pump & Sampling & Sampling & Resin & Resin & Temp & \multicolumn{3}{|c|}{ Effluent Bottle Weight, g } & \multicolumn{3}{|c|}{ Sample Vial Weight, g } \\
\hline ID No. & $\begin{array}{l}\text { Size } \\
(\mathrm{mL})\end{array}$ & $\begin{array}{l}\text { Set } \\
\left({ }^{\circ} \mathrm{C}\right)\end{array}$ & $\begin{array}{l}\text { Setting } \\
(\mathrm{mL} / \mathrm{min})\end{array}$ & Start Time & Stop Time & $\begin{array}{l}\text { Height } \\
(\mathrm{cm})\end{array}$ & Color & $\left({ }^{\circ} \mathrm{C}\right)$ & Tare & Gross & Net & Tare & Gross & Net \\
\hline \multicolumn{4}{|c|}{ Elution (EL) Phase Start Date/Time: } & $3 / 19 / 126: 42$ & & & & & & & & & & \\
\hline B4B-EL-CP & 60 & 25 & 0.08 & $3 / 19 / 126: 42$ & 3/19/12 17:42 & 1.45 & dark red & 25.2 & 14.69 & 65.36 & 50.67 & 8.48 & 14.43 & 5.95 \\
\hline B4B-EDI-CP & 20 & 25 & 0.09 & 3/19/12 17:55 & 3/19/12 18:55 & 1.45 & $\begin{array}{c}\text { orange } \\
\text { red }\end{array}$ & 24.3 & 8.37 & $\begin{array}{c}\text { NA } \\
\text { (spilled) }\end{array}$ & $\begin{array}{c}\text { NA } \\
\text { (spilled) }\end{array}$ & NA & NA & NA \\
\hline B4B-RG-CP & 20 & 25 & 0.09 & 3/19/12 19:05 & 3/19/12 22:05 & 1.50 & dark red & 23.6 & 8.39 & 24.05 & 15.66 & NA & NA & NA \\
\hline
\end{tabular}


Table A.21. Datasheet for Column B5 Loading and Rinsing Information

\begin{tabular}{|c|c|c|c|c|c|c|c|c|c|c|c|c|c|c|}
\hline Sample & Bottle & Temp & Pump & Sampling & Sampling & Resin & Resin & Temp & \multicolumn{3}{|c|}{ Effluent Bottle Weight, g } & \multicolumn{3}{|c|}{ Sample Vial Weight, g } \\
\hline ID No. & $\begin{array}{l}\text { Size } \\
(\mathrm{mL})\end{array}$ & $\begin{array}{l}\text { Set } \\
\left({ }^{\circ} \mathrm{C}\right)\end{array}$ & $\begin{array}{l}\text { Setting } \\
(\mathrm{mL} / \mathrm{min})\end{array}$ & Start Time & Stop Time & $\begin{array}{l}\text { Height } \\
(\mathrm{cm})\end{array}$ & Color & $\left({ }^{\circ} \mathrm{C}\right)$ & Tare & Gross & Net & Tare & Gross & Net \\
\hline B5-LD-0 & 20 & 40 & NA & $3 / 20 / 126: 42$ & $3 / 20 / 126: 42$ & 1.50 & dark red & 45.3 & NA & NA & NA & 8.47 & 12.53 & 4.06 \\
\hline \multicolumn{4}{|c|}{ Loading (LD) Phase Start Date/Time: } & 3/20/12 6:48 & & & & & & & & & & \\
\hline B5-LD-006 & 20 & 40 & 10.62 & 3/20/12 6:54 & 3/20/12 6:54 & NA & dark red & 42.2 & NA & NA & NA & 8.39 & 12.86 & 4.47 \\
\hline B5-LD-012 & 20 & 40 & 10.62 & 3/20/12 7:00 & 3/20/12 7:00 & NA & dark red & 40.7 & NA & NA & NA & 8.39 & 12.37 & 3.98 \\
\hline B5-LD-018 & 20 & 40 & 10.62 & 3/20/12 7:06 & 3/20/12 7:06 & NA & dark red & 39.8 & NA & NA & NA & 8.43 & 12.90 & 4.47 \\
\hline B5-LD-024 & 20 & 40 & 10.62 & 3/20/12 7:12 & 3/20/12 7:12 & NA & dark red & 39.4 & NA & NA & NA & 8.41 & 12.90 & 4.49 \\
\hline B5-LD-036 & 20 & 40 & 10.62 & 3/20/12 7:24 & $3 / 20 / 127: 24$ & NA & dark red & 39.6 & NA & NA & NA & 8.45 & 11.78 & 3.33 \\
\hline B5-LD-048 & 20 & 40 & 10.62 & 3/20/12 7:36 & 3/20/12 7:36 & NA & dark red & 39.9 & NA & NA & NA & 8.46 & 12.98 & 4.52 \\
\hline B5-LD-060 & 20 & 40 & 10.62 & $3 / 20 / 127: 48$ & 3/20/12 7:48 & NA & dark red & 40.2 & NA & NA & NA & 8.48 & 12.89 & 4.41 \\
\hline B5-LD-080 & 20 & 40 & 10.62 & 3/20/12 8:08 & 3/20/12 8:08 & NA & dark red & 40.2 & NA & NA & NA & 8.43 & 12.98 & 4.55 \\
\hline B5-LD-120 & 20 & 40 & 10.62 & 3/20/12 8:48 & 3/20/12 8:48 & NA & dark red & 40.0 & NA & NA & NA & 8.43 & 12.94 & 4.51 \\
\hline B5-LD-180 & 20 & 40 & 10.62 & 3/20/12 9:48 & 3/20/12 9:48 & NA & dark red & 40.0 & NA & NA & NA & 8.52 & 12.96 & 4.44 \\
\hline B5-LD-240 & 20 & 40 & 10.62 & 3/20/12 10:48 & 3/20/12 10:48 & NA & dark red & 40.0 & NA & NA & NA & 8.46 & 12.90 & 4.44 \\
\hline B5-LD-600 & 20 & 40 & 10.62 & 3/20/12 16:48 & 3/20/12 16:48 & NA & dark red & 39.8 & NA & NA & NA & 8.44 & 12.65 & 4.21 \\
\hline B5-FD-CP & 20 & 40 & 0.09 & $3 / 20 / 12$ 16:56 & 3/20/12 19:26 & 1.50 & dark red & 40.7 & 8.41 & 22.73 & 14.32 & NA & NA & NA \\
\hline B5-FDI-CP & 20 & 25 & 0.09 & 3/20/12 19:58 & 3/20/12 22:28 & 1.50 & dark red & 24.4 & 8.52 & 21.58 & 13.06 & NA & NA & NA \\
\hline B5-AN-CP & 20 & 25 & 0.09 & 3/20/12 22:31 & 3/20/12 23:31 & 1.50 & dark red & 25.1 & 8.55 & 13.58 & 5.03 & NA & NA & NA \\
\hline
\end{tabular}

Table A.22. Datasheet for Column B5 Elution, Rinsing, and Regeneration Information

\begin{tabular}{|c|c|c|c|c|c|c|c|c|c|c|c|c|c|c|}
\hline Sample & Bottle & Temp & Pump & Sampling & Sampling & Resin & Resin & Temp & \multicolumn{3}{|c|}{ Effluent Bottle Weight, g } & \multicolumn{3}{|c|}{ Sample Vial Weight, g } \\
\hline ID No. & $\begin{array}{l}\text { Size } \\
(\mathrm{mL})\end{array}$ & $\begin{array}{l}\text { Set } \\
\left({ }^{\circ} \mathrm{C}\right)\end{array}$ & $\begin{array}{l}\text { Setting } \\
\text { (mL/min) }\end{array}$ & Start Time & Stop Time & $\begin{array}{l}\text { Height } \\
(\mathrm{cm})\end{array}$ & Color & $\left({ }^{\circ} \mathrm{C}\right)$ & Tare & Gross & Net & Tare & Gross & Net \\
\hline \multicolumn{4}{|c|}{ Elution (EL) Phase Start Date/Time: } & 3/21/12 6:40 & & & & & & & & & & \\
\hline B5-EL-CP & 60 & 25 & 0.08 & $3 / 21 / 126: 40$ & $3 / 21 / 1217: 40$ & 1.15 & orange & 24.6 & 14.62 & 64.96 & 50.34 & 8.43 & 15.64 & 7.21 \\
\hline B5-EDI-CP & 20 & 25 & 0.09 & 3/21/12 17:47 & 3/21/12 18:47 & 1.15 & orange & 24.4 & 8.49 & 13.52 & 5.03 & NA & NA & NA \\
\hline
\end{tabular}


Table A.23. Datasheet for Column C1 Pretreatment, Loading, and Rinsing Information

\begin{tabular}{|c|c|c|c|c|c|c|c|c|c|c|c|c|c|c|}
\hline \multirow{2}{*}{$\begin{array}{l}\text { Sample } \\
\text { ID No. }\end{array}$} & \multirow{2}{*}{$\begin{array}{c}\text { Bottle } \\
\text { Size } \\
(\mathrm{mL})\end{array}$} & \multirow{2}{*}{$\begin{array}{c}\text { Temp } \\
\text { Set } \\
\left({ }^{\circ} \mathrm{C}\right)\end{array}$} & \multirow{2}{*}{$\begin{array}{c}\text { Pump } \\
\begin{array}{c}\text { Setting } \\
\text { (mL/min) }\end{array}\end{array}$} & \multirow{2}{*}{$\begin{array}{l}\text { Sampling } \\
\text { Start Time }\end{array}$} & \multirow{2}{*}{$\begin{array}{l}\text { Sampling } \\
\text { Stop Time }\end{array}$} & \multirow{2}{*}{$\begin{array}{c}\text { Resin } \\
\begin{array}{c}\text { Height } \\
\text { (cm) }\end{array}\end{array}$} & \multirow{2}{*}{$\begin{array}{l}\text { Resin } \\
\text { Color }\end{array}$} & \multirow{2}{*}{$\begin{array}{l}\text { Temp } \\
\left({ }^{\circ} \mathrm{C}\right)\end{array}$} & \multicolumn{3}{|c|}{ Effluent Bottle Weight, g } & \multicolumn{3}{|c|}{ Sample Vial Weight, g } \\
\hline & & & & & & & & & Tare & Gross & Net & Tare & Gross & Net \\
\hline C1-PT-DIW1 & 20 & 25 & 0.09 & 3/26/12 13:05 & $3 / 26 / 1215: 35$ & 1.10 & dark red & 23.6 & 8.44 & 20.45 & 12.01 & NA & NA & NA \\
\hline C1-PT-DIW2 & 20 & 25 & 0.09 & 3/27/12 13:40 & $3 / 27 / 1214: 40$ & 0.95 & orange & 23.5 & 8.43 & 13.27 & 4.84 & NA & NA & NA \\
\hline C1-PT-NaOH & 20 & 25 & 0.09 & 3/27/12 14:48 & 3/27/12 17:03 & 1.00 & dark red & 23.4 & 8.55 & 25.06 & 16.51 & NA & NA & NA \\
\hline C1-LD-0 & 20 & 30 & NA & $3 / 28 / 126: 43$ & 3/28/12 6:43 & 1.00 & dark red & 32.6 & NA & NA & NA & 8.46 & 12.94 & 4.48 \\
\hline C1-LD-012 & 20 & 30 & 10.62 & 3/28/12 6:57 & 3/28/12 6:57 & NA & dark red & 30.5 & NA & NA & NA & 8.43 & 12.92 & 4.49 \\
\hline C1-LD-018 & 20 & 30 & 10.62 & $3 / 28 / 127: 03$ & 3/28/12 7:03 & NA & dark red & 29.9 & NA & NA & NA & 8.52 & 13.26 & 4.74 \\
\hline C1-LD-024 & 20 & 30 & 10.62 & 3/28/12 7:09 & 3/28/12 7:09 & NA & dark red & 29.6 & NA & NA & NA & 8.39 & 12.47 & 4.08 \\
\hline C1-LD-036 & 20 & 30 & 10.62 & $3 / 28 / 12$ 7:21 & 3/28/12 7:21 & NA & dark red & 29.9 & NA & NA & NA & 8.45 & 12.99 & 4.54 \\
\hline C1-LD-048 & 20 & 30 & 10.62 & 3/28/12 7:33 & 3/28/12 7:33 & NA & dark red & 29.9 & NA & NA & NA & 8.42 & 12.89 & 4.47 \\
\hline C1-LD-060 & 20 & 30 & 10.62 & $3 / 28 / 12$ 7:45 & 3/28/12 7:45 & NA & dark red & 30.0 & NA & NA & NA & 8.41 & 13.04 & 4.63 \\
\hline C1-LD-600 & 20 & 30 & 10.62 & 3/28/12 16:46 & 3/28/12 16:46 & 1.00 & dark red & 30.1 & NA & NA & NA & 8.53 & 13.13 & 4.60 \\
\hline C1-FD-CP & 20 & 30 & 0.09 & 3/28/12 17:00 & 3/28/12 19:30 & 1.00 & dark red & 30.1 & 8.44 & 22.54 & 14.10 & NA & NA & NA \\
\hline C1-FDI-CP & 20 & 25 & 0.09 & 3/28/12 19:37 & 3/28/12 22:07 & 1.00 & dark red & 25.8 & 8.54 & 20.76 & 12.22 & NA & NA & NA \\
\hline C1-AN-CP & 20 & 25 & 0.09 & 3/28/12 22:12 & 3/28/12 23:12 & 1.00 & dark red & 23.7 & 8.48 & 13.33 & 4.85 & NA & NA & NA \\
\hline
\end{tabular}


Table A.24. Datasheet for Column C1 Elution, Rinsing, and Regeneration Information

\begin{tabular}{|c|c|c|c|c|c|c|c|c|c|c|c|c|c|c|}
\hline Sample & Bottle & Temp & Pump & Sampling & Sampling & Resin & Resin & Temp & \multicolumn{3}{|c|}{ Effluent Bottle Weight, g } & \multicolumn{3}{|c|}{ Sample Vial Weight, g } \\
\hline ID No. & $\begin{array}{l}\text { Size } \\
(\mathrm{mL})\end{array}$ & $\begin{array}{l}\text { Set } \\
\left({ }^{\circ} \mathrm{C}\right) \\
\end{array}$ & $\begin{array}{c}\text { Setting } \\
(\mathrm{mL} / \mathrm{min})\end{array}$ & Start Time & Stop Time & $\begin{array}{c}\text { Height } \\
(\mathrm{cm})\end{array}$ & Color & $\left({ }^{\circ} \mathrm{C}\right)$ & Tare & Gross & Net & Tare & Gross & Net \\
\hline \multicolumn{4}{|c|}{ Elution (EL) Phase Start Date/Time: } & 3/29/12 6:37 & & & & & & & & & & \\
\hline C1-EL-CP & 60 & 25 & 0.08 & 3/29/12 6:37 & 3/29/12 16:37 & 1.00 & orange & 26.1 & 14.58 & 58.03 & 43.45 & 8.43 & 16.29 & 7.86 \\
\hline C1-EDI-CP & 20 & 25 & 0.09 & 3/29/12 16:43 & 3/29/12 17:45 & 0.95 & orange & 25.1 & 8.38 & 13.11 & 4.73 & NA & NA & NA \\
\hline C1-RG-CP & 20 & 25 & 0.09 & 3/29/12 18:00 & 3/29/12 20:30 & 1.10 & dark red & 24.4 & 8.46 & 20.20 & 11.74 & NA & NA & NA \\
\hline
\end{tabular}

Table A.25. Datasheet for Column C2 Loading and Rinsing Information

\begin{tabular}{|c|c|c|c|c|c|c|c|c|c|c|c|c|c|c|}
\hline Sample & Bottle & Temp & Pump & Sampling & Sampling & Resin & Resin & Temp & \multicolumn{3}{|c|}{ Effluent Bottle Weight, g } & \multicolumn{3}{|c|}{ Sample Vial Weight, g } \\
\hline ID No. & $\begin{array}{l}\text { Size } \\
(\mathrm{mL})\end{array}$ & $\begin{array}{l}\text { Set } \\
\left({ }^{\circ} \mathrm{C}\right) \\
\end{array}$ & $\begin{array}{c}\text { Setting } \\
\text { (mL/min) }\end{array}$ & Start Time & Stop Time & $\begin{array}{l}\text { Height } \\
(\mathrm{cm})\end{array}$ & Color & $\left({ }^{\circ} \mathrm{C}\right)$ & Tare & Gross & Net & Tare & Gross & Net \\
\hline C2-LD-0 & 20 & 30 & NA & 4/2/12 6:26 & 4/2/12 6:26 & 1.10 & dark red & 38.0 & NA & NA & NA & 8.48 & 12.94 & 4.46 \\
\hline \multicolumn{2}{|c|}{ Loading (LD) } & Phase Sta & Date/Time: & 4/2/12 6:30 & & & & & & & & & & \\
\hline C2-LD-006 & 20 & 30 & 14.16 & 4/2/12 6:36 & 4/2/12 6:36 & NA & dark red & 35.0 & NA & NA & NA & 8.54 & 12.45 & 3.91 \\
\hline C2-LD-012 & 20 & 30 & 14.16 & 4/2/12 6:42 & 4/2/12 6:42 & NA & dark red & 33.7 & NA & NA & NA & 8.54 & 13.11 & 4.57 \\
\hline C2-LD-018 & 20 & 30 & 14.16 & 4/2/12 6:48 & $4 / 2 / 126: 48$ & NA & dark red & 32.7 & NA & NA & NA & 8.67 & 13.27 & 4.60 \\
\hline C2-LD-024 & 20 & 30 & 14.16 & 4/2/12 6:54 & 4/2/12 6:54 & NA & dark red & 32.0 & NA & NA & NA & 8.57 & 12.84 & 4.27 \\
\hline C2-LD-036 & 20 & 30 & 14.16 & 4/2/12 7:06 & 4/2/12 7:06 & NA & dark red & 30.8 & NA & NA & NA & 8.61 & 13.22 & 4.61 \\
\hline C2-LD-048 & 20 & 30 & 14.16 & 4/2/12 7:18 & 4/2/12 7:18 & NA & dark red & 30.2 & NA & NA & NA & 8.87 & 13.06 & 4.19 \\
\hline C2-LD-060 & 20 & 30 & 14.16 & 4/2/12 7:30 & 4/2/12 7:30 & NA & dark red & 30.1 & NA & NA & NA & 8.52 & 13.18 & 4.66 \\
\hline C2-LD-080 & 20 & 30 & 14.16 & 4/2/12 7:50 & 4/2/12 7:50 & NA & dark red & 29.8 & NA & NA & NA & 8.55 & 13.24 & 4.69 \\
\hline C2-LD-120 & 20 & 30 & 14.16 & 4/2/12 8:30 & 4/2/12 8:30 & NA & dark red & 30.0 & NA & NA & NA & 8.62 & 13.31 & 4.69 \\
\hline C2-LD-180 & 20 & 30 & 14.16 & 4/2/12 9:30 & 4/2/12 9:30 & NA & dark red & 29.9 & NA & NA & NA & 8.64 & 13.48 & 4.84 \\
\hline C2-LD-240 & 20 & 30 & 14.16 & 4/2/12 10:30 & 4/2/12 10:30 & NA & dark red & 30.0 & NA & NA & NA & 8.63 & 13.39 & 4.76 \\
\hline C2-LD-600 & 20 & 30 & 14.16 & 4/2/12 16:30 & 4/2/12 16:30 & NA & dark red & 29.9 & NA & NA & NA & 8.57 & 13.04 & 4.47 \\
\hline C2-FD-CP & 20 & 30 & 0.09 & $4 / 2 / 1216: 42$ & 4/2/12 19:12 & NA & dark red & 29.9 & 8.57 & 22.37 & 13.80 & NA & NA & NA \\
\hline C2-FDI-CP & 20 & 25 & 0.09 & 4/2/12 19:20 & 4/2/12 21:50 & NA & dark red & 24.1 & 8.53 & 20.93 & 12.40 & NA & NA & NA \\
\hline C2-AN-CP & 20 & 25 & 0.09 & 4/2/12 21:54 & 4/2/12 22:54 & 1.10 & dark red & 24.2 & 8.68 & 13.50 & 4.82 & NA & NA & NA \\
\hline
\end{tabular}


Table A.26. Datasheet for Column C2 Elution, Rinsing, and Regeneration Information

\begin{tabular}{|c|c|c|c|c|c|c|c|c|c|c|c|c|c|c|}
\hline Sample & Bottle & Temp & Pump & Sampling & Sampling & Resin & Resin & Temp & \multicolumn{3}{|c|}{ Effluent Bottle Weight, g } & \multicolumn{3}{|c|}{ Sample Vial Weight, g } \\
\hline ID No. & $\begin{array}{l}\text { Size } \\
(\mathrm{mL})\end{array}$ & $\begin{array}{l}\text { Set } \\
\left({ }^{\circ} \mathrm{C}\right) \\
\end{array}$ & $\begin{array}{c}\text { Setting } \\
(\mathrm{mL} / \mathrm{min})\end{array}$ & Start Time & Stop Time & $\begin{array}{c}\text { Height } \\
(\mathrm{cm})\end{array}$ & Color & $\left({ }^{\circ} \mathrm{C}\right)$ & Tare & Gross & Net & Tare & Gross & Net \\
\hline \multicolumn{4}{|c|}{ Elution (EL) Phase Start Date/Time: } & 4/3/12 6:22 & & & & & & & & & & \\
\hline C2-EL-CP & 60 & 25 & 0.08 & 4/3/12 6:22 & 4/3/12 16:22 & 1.05 & orange & 24.4 & 14.65 & 57.96 & 43.31 & 8.75 & 16.60 & 7.85 \\
\hline C2-EDI-CP & 20 & 25 & 0.09 & 4/3/12 16:30 & 4/3/12 17:30 & 1.05 & orange & 23.9 & 8.60 & 13.25 & 4.65 & NA & NA & NA \\
\hline C2-RG-CP & 20 & 25 & 0.09 & 4/3/12 17:35 & 4/3/12 20:05 & 1.15 & dark red & 24.2 & 8.64 & 20.51 & 11.87 & NA & NA & NA \\
\hline
\end{tabular}

Table A.27. Datasheet for Column C3 Loading and Rinsing Information

\begin{tabular}{|c|c|c|c|c|c|c|c|c|c|c|c|c|c|c|}
\hline Sample & Bottle & Temp & Pump & Sampling & Sampling & Resin & Resin & Temp & \multicolumn{3}{|c|}{ Effluent Bottle Weight, g } & \multicolumn{3}{|c|}{ Sample Vial Weight, g } \\
\hline ID No. & $\begin{array}{l}\text { Size } \\
(\mathrm{mL})\end{array}$ & $\begin{array}{l}\text { Set } \\
\left({ }^{\circ} \mathrm{C}\right)\end{array}$ & $\begin{array}{l}\text { Setting } \\
\text { (mL/min) }\end{array}$ & Start Time & Stop Time & $\begin{array}{l}\text { Height } \\
\text { (cm) }\end{array}$ & Color & $\left({ }^{\circ} \mathrm{C}\right)$ & Tare & Gross & Net & Tare & Gross & Net \\
\hline C3-LD-0 & 20 & 30 & NA & 4/4/12 6:31 & $4 / 4 / 126: 31$ & 1.15 & dark red & 30.9 & NA & NA & NA & 8.59 & 13.31 & 4.72 \\
\hline \multicolumn{4}{|c|}{ Loading (LD) Phase Start Date/Time: } & 4/4/12 6:35 & & & & & & & & & & \\
\hline C3-LD-006 & 20 & 30 & 7.08 & $4 / 4 / 126: 41$ & 4/4/12 6:41 & NA & dark red & 30.0 & NA & NA & NA & 8.61 & 13.37 & 4.76 \\
\hline C3-LD-012 & 20 & 30 & 7.08 & 4/4/12 6:47 & 4/4/12 6:47 & NA & dark red & 29.6 & NA & NA & NA & 8.65 & 13.11 & 4.46 \\
\hline C3-LD-018 & 20 & 30 & 7.08 & $4 / 4 / 126: 53$ & 4/4/12 6:53 & NA & dark red & 29.6 & NA & NA & NA & 8.61 & 13.57 & 4.96 \\
\hline C3-LD-024 & 20 & 30 & 7.08 & $4 / 4 / 126: 59$ & $4 / 4 / 126: 59$ & NA & dark red & 29.7 & NA & NA & NA & 8.64 & 13.45 & 4.81 \\
\hline C3-LD-036 & 20 & 30 & 7.08 & $4 / 4 / 127: 11$ & $4 / 4 / 127: 11$ & NA & dark red & 30.1 & NA & NA & NA & 8.56 & 13.51 & 4.95 \\
\hline C3-LD-048 & 20 & 30 & 7.08 & 4/4/12 7:23 & 4/4/12 7:23 & NA & dark red & 30.0 & NA & NA & NA & 8.56 & 13.30 & 4.74 \\
\hline C3-LD-060 & 20 & 30 & 7.08 & $4 / 4 / 127: 35$ & $4 / 4 / 127: 35$ & NA & dark red & 30.0 & NA & NA & NA & 8.64 & 13.40 & 4.76 \\
\hline C3-LD-080 & 20 & 30 & 7.08 & 4/4/12 7:55 & 4/4/12 7:55 & NA & dark red & 29.9 & NA & NA & NA & 8.67 & 13.34 & 4.67 \\
\hline C3-LD-120 & 20 & 30 & 7.08 & 4/4/12 8:35 & 4/4/12 8:35 & NA & dark red & 29.8 & NA & NA & NA & 8.47 & 13.23 & 4.76 \\
\hline C3-LD-180 & 20 & 30 & 7.08 & 4/4/12 9:35 & 4/4/12 9:35 & NA & dark red & 29.8 & NA & NA & NA & 8.53 & 13.35 & 4.82 \\
\hline C3-LD-240 & 20 & 30 & 7.08 & 4/4/12 10:35 & 4/4/12 10:35 & NA & dark red & 29.6 & NA & NA & NA & 8.51 & 13.09 & 4.58 \\
\hline C3-LD-600 & 20 & 30 & 7.08 & 4/4/12 16:35 & 4/4/12 16:35 & NA & dark red & 30.0 & NA & NA & NA & 8.67 & 13.47 & 4.80 \\
\hline C3-FD-CP & 20 & 30 & 0.09 & 4/4/12 16:47 & 4/4/12 19:17 & NA & dark red & 30.1 & 8.69 & 22.99 & 14.30 & NA & NA & NA \\
\hline C3-FDI-CP & 20 & 25 & 0.09 & 4/4/12 19:22 & 4/4/12 21:52 & NA & dark red & 24.8 & 8.57 & 21.07 & 12.50 & NA & NA & NA \\
\hline C3-AN-CP & 20 & 25 & 0.09 & $4 / 4 / 12$ 21:56 & $4 / 4 / 1222: 56$ & 1.15 & dark red & 24.6 & 8.63 & 13.47 & 4.84 & NA & NA & NA \\
\hline
\end{tabular}


Table A.28. Datasheet for Column C3 Elution, Rinsing, and Regeneration Information

\begin{tabular}{|c|c|c|c|c|c|c|c|c|c|c|c|c|c|c|}
\hline Sample & Bottle & Temp & Pump & Sampling & Sampling & Resin & Resin & Temp & \multicolumn{3}{|c|}{ Effluent Bottle Weight, g } & \multicolumn{3}{|c|}{ Sample Vial Weight, g } \\
\hline ID No. & $\begin{array}{l}\text { Size } \\
(\mathrm{mL})\end{array}$ & $\begin{array}{l}\text { Set } \\
\left({ }^{\circ} \mathrm{C}\right) \\
\end{array}$ & $\begin{array}{c}\text { Setting } \\
(\mathrm{mL} / \mathrm{min})\end{array}$ & Start Time & Stop Time & $\begin{array}{c}\text { Height } \\
(\mathrm{cm})\end{array}$ & Color & $\left({ }^{\circ} \mathrm{C}\right)$ & Tare & Gross & Net & Tare & Gross & Net \\
\hline \multicolumn{4}{|c|}{ Elution (EL) Phase Start Date/Time: } & 4/5/12 6:28 & & & & & & & & & & \\
\hline C3-EL-CP & 60 & 25 & 0.08 & $4 / 5 / 126: 28$ & 4/5/12 16:28 & 1.05 & orange & 26.3 & 14.87 & 58.10 & 43.23 & 8.50 & 17.54 & 9.04 \\
\hline C3-EDI-CP & 20 & 25 & 0.09 & 4/5/12 16:45 & 4/5/12 17:45 & 1.05 & orange & 25.1 & 8.56 & 13.32 & 4.76 & NA & NA & NA \\
\hline C3-RG-CP & 20 & 25 & 0.09 & $4 / 5 / 12$ 17:50 & 4/5/12 20:20 & 1.15 & dark red & 25.8 & 8.66 & 20.65 & 11.99 & NA & NA & NA \\
\hline
\end{tabular}

Table A.29. Datasheet for Column C4 Loading and Rinsing Information

\begin{tabular}{|c|c|c|c|c|c|c|c|c|c|c|c|c|c|c|}
\hline Sample & Bottle & Temp & Pump & Sampling & Sampling & Resin & Resin & Temp & \multicolumn{3}{|c|}{ Effluent Bottle Weight, g } & \multicolumn{3}{|c|}{ Sample Vial Weight, g } \\
\hline ID No. & $\begin{array}{l}\text { Size } \\
(\mathrm{mL})\end{array}$ & $\begin{array}{l}\text { Set } \\
\left({ }^{\circ} \mathrm{C}\right) \\
\end{array}$ & $\begin{array}{c}\text { Setting } \\
\text { (mL/min) }\end{array}$ & Start Time & Stop Time & $\begin{array}{l}\text { Height } \\
\text { (cm) }\end{array}$ & Color & $\left({ }^{\circ} \mathrm{C}\right)$ & Tare & Gross & Net & Tare & Gross & Net \\
\hline C4-LD-0 & 20 & 30 & NA & 4/9/12 6:39 & 4/9/12 6:39 & 1.10 & dark red & 32.5 & NA & NA & NA & 8.70 & 13.43 & 4.73 \\
\hline \multicolumn{2}{|c|}{ Loading (LD) } & hase Sta & Date/Time: & 4/9/12 6:40 & & & & & & & & & & \\
\hline C4-LD-006 & 20 & 30 & 10.62 & 4/9/12 6:46 & 4/9/12 6:46 & NA & dark red & 30.8 & NA & NA & NA & 8.52 & 13.22 & 4.70 \\
\hline C4-LD-012 & 20 & 30 & 10.62 & 4/9/12 6:52 & 4/9/12 6:52 & NA & dark red & 29.9 & NA & NA & NA & 8.65 & 13.47 & 4.82 \\
\hline C4-LD-018 & 20 & 30 & 10.62 & 4/9/12 6:58 & 4/9/12 6:58 & NA & dark red & 29.6 & NA & NA & NA & 8.40 & 12.92 & 4.52 \\
\hline C4-LD-024 & 20 & 30 & 10.62 & 4/9/12 7:05 & 4/9/12 7:05 & NA & dark red & 29.6 & NA & NA & NA & 8.49 & 13.17 & 4.68 \\
\hline C4-LD-036 & 20 & 30 & 10.62 & 4/9/12 7:16 & 4/9/12 7:16 & NA & dark red & 30.0 & NA & NA & NA & 8.54 & 13.33 & 4.79 \\
\hline C4-LD-048 & 20 & 30 & 10.62 & 4/9/12 7:28 & 4/9/12 7:28 & NA & dark red & 29.8 & NA & NA & NA & 8.63 & 13.29 & 4.66 \\
\hline C4-LD-060 & 20 & 30 & 10.62 & 4/9/12 7:40 & 4/9/12 7:40 & NA & dark red & 29.8 & NA & NA & NA & 8.61 & 13.35 & 4.74 \\
\hline C4-LD-080 & 20 & 30 & 10.62 & 4/9/12 8:00 & 4/9/12 8:00 & NA & dark red & 29.9 & NA & NA & NA & 8.67 & 13.47 & 4.80 \\
\hline C4-LD-120 & 20 & 30 & 10.62 & 4/9/12 8:40 & 4/9/12 8:40 & NA & dark red & 30.0 & NA & NA & NA & 8.78 & 13.44 & 4.66 \\
\hline C4-LD-180 & 20 & 30 & 10.62 & 4/9/12 9:40 & 4/9/12 9:40 & NA & dark red & 29.6 & NA & NA & NA & 8.59 & 13.26 & 4.67 \\
\hline C4-LD-240 & 20 & 30 & 10.62 & 4/9/12 10:40 & 4/9/12 10:40 & NA & dark red & 29.3 & NA & NA & NA & 8.59 & 13.42 & 4.83 \\
\hline C4-LD-600 & 20 & 30 & 10.62 & 4/9/12 16:41 & 4/9/12 16:41 & NA & dark red & 30.2 & NA & NA & NA & 8.67 & 13.40 & 4.73 \\
\hline C4-FD-CP & 20 & 25 & 0.09 & 4/9/12 17:03 & 4/9/12 19:33 & NA & dark red & 25.7 & 8.48 & 22.47 & 13.99 & NA & NA & NA \\
\hline C4-FDI-CP & 20 & 25 & 0.09 & 4/9/12 19:36 & 4/9/12 22:06 & NA & dark red & 26.3 & 8.57 & 20.95 & 12.38 & NA & NA & NA \\
\hline
\end{tabular}


Table A.30. Datasheet for Column C4B Loading and Rinsing Information

\begin{tabular}{|c|c|c|c|c|c|c|c|c|c|c|c|c|c|c|}
\hline Sample & Bottle & Temp & Pump & Sampling & Sampling & Resin & Resin & Temp & \multicolumn{3}{|c|}{ Effluent Bottle Weight, g } & \multicolumn{3}{|c|}{ Sample Vial Weight, g } \\
\hline ID No. & $\begin{array}{l}\text { Size } \\
(\mathrm{mL})\end{array}$ & $\begin{array}{l}\text { Set } \\
\left({ }^{\circ} \mathrm{C}\right)\end{array}$ & $\begin{array}{c}\text { Setting } \\
(\mathrm{mL} / \mathrm{min})\end{array}$ & Start Time & Stop Time & $\begin{array}{l}\text { Height } \\
(\mathrm{cm})\end{array}$ & Color & $\left({ }^{\circ} \mathrm{C}\right)$ & Tare & Gross & Net & Tare & Gross & Net \\
\hline C4B-LD-0 & 20 & 50 & NA & 4/11/12 8:55 & $4 / 11 / 128: 55$ & 1.1 & dark red & 49.9 & NA & NA & NA & 8.51 & 13.23 & 4.72 \\
\hline \multicolumn{4}{|c|}{ Loading (LD) Phase Start Date/Time: } & 4/11/12 9:00 & & & & & & & & & & \\
\hline C4B-LD-004 & 20 & 50 & 0.08 & 4/11/12 13:15 & 4/11/12 13:15 & NA & dark red & 50.1 & NA & NA & NA & 8.72 & 13.28 & 4.56 \\
\hline C4B-LD-008 & 20 & 50 & 0.08 & 4/11/12 17:11 & 4/11/12 17:11 & NA & dark red & 50.0 & NA & NA & NA & 8.65 & 13.20 & 4.55 \\
\hline C4B-LD-012 & 20 & 50 & 0.08 & 4/11/12 21:01 & 4/11/12 21:01 & NA & dark red & 50.0 & NA & NA & NA & 8.66 & 12.83 & 4.17 \\
\hline C4B-LD-024 & 20 & 50 & 0.08 & 4/12/12 9:00 & 4/12/12 9:00 & NA & dark red & 50.0 & NA & NA & NA & 8.71 & 13.37 & 4.66 \\
\hline C4B-LD-072 & 20 & 50 & 0.08 & 4/14/12 9:00 & 4/14/12 9:00 & NA & $\begin{array}{c}\text { almost } \\
\text { black }\end{array}$ & 50.0 & NA & NA & NA & 8.67 & 13.16 & 4.49 \\
\hline C4B-LD-120 & 20 & 50 & 0.08 & 4/16/12 9:00 & 4/16/12 9:00 & NA & dark red & 49.8 & NA & NA & NA & 8.70 & 13.20 & 4.50 \\
\hline C4B-LD-168 & 20 & 50 & 0.08 & 4/18/12 9:00 & 4/18/12 9:00 & NA & dark red & 49.9 & NA & NA & NA & 8.65 & 13.10 & 4.54 \\
\hline C4B-LD-336 & 20 & 50 & 0.08 & 4/25/12 9:00 & 4/25/12 9:00 & NA & dark red & 49.9 & NA & NA & NA & 8.71 & 13.08 & 4.37 \\
\hline C4B-LD-504 & 20 & 50 & 0.08 & 5/2/12 9:00 & 5/2/12 9:00 & NA & dark red & 49.2 & NA & NA & NA & 8.50 & 13.00 & 4.50 \\
\hline C4B-FD-CP & 20 & 50 & 0.08 & 5/11/12 9:31 & 5/11/12 13:21 & NA & dark red & 50.4 & 8.76 & 22.32 & 13.56 & NA & NA & NA \\
\hline C4B-FDI-CP & 20 & 25 & 0.09 & 5/11/12 13:25 & 5/11/12 15:55 & 1.1 & dark red & 22.8 & 8.70 & 22.40 & 13.70 & NA & NA & NA \\
\hline C4B-AN-CP & 20 & 25 & 0.09 & 5/11/12 16:00 & 5/11/12 17:00 & 1.1 & dark red & 22.8 & 8.52 & 12.88 & 4.36 & NA & NA & NA \\
\hline
\end{tabular}

Table A.31. Datasheet for Column C4B Elution, Rinsing, and Regeneration Information

\begin{tabular}{|c|c|c|c|c|c|c|c|c|c|c|c|c|c|c|}
\hline Sample & Bottle & Temp & Pump & Sampling & Sampling & Resin & Resin & Temp & \multicolumn{3}{|c|}{ Effluent Bottle Weight, g } & \multicolumn{3}{|c|}{ Sample Vial Weight, g } \\
\hline ID No. & $\begin{array}{l}\text { Size } \\
(\mathrm{mL})\end{array}$ & $\begin{array}{l}\text { Set } \\
\left({ }^{\circ} \mathrm{C}\right)\end{array}$ & $\begin{array}{l}\text { Setting } \\
(\mathrm{mL} / \mathrm{min})\end{array}$ & Start Time & Stop Time & $\begin{array}{l}\text { Height } \\
\text { (cm) }\end{array}$ & Color & $\left({ }^{\circ} \mathrm{C}\right)$ & Tare & Gross & Net & Tare & Gross & Net \\
\hline \multicolumn{4}{|c|}{ Elution (EL) Phase Start Date/Time: } & $5 / 14 / 126: 55$ & & & & & & & & & & \\
\hline C4B-EL-CP & 60 & 25 & 0.08 & 5/14/12 6:55 & $5 / 14 / 1217: 25$ & 1.1 & orange & 19.7 & 14.74 & 58.14 & 43.40 & 8.64 & 18.58 & 9.94 \\
\hline C4B-EDI-CP & 20 & 25 & 0.09 & 5/14/12 17:32 & 5/14/12 18:32 & 1.1 & orange & 20.3 & 8.53 & 13.70 & 5.17 & NA & NA & NA \\
\hline C4B-RG-CP & 20 & 25 & 0.09 & 5/14/12 18:49 & 5/14/12 21:19 & 1.3 & dark red & 20.2 & 8.75 & 19.89 & 11.14 & NA & NA & NA \\
\hline
\end{tabular}


Table A.32. Datasheet for Column C5 Loading and Rinsing Information

\begin{tabular}{|c|c|c|c|c|c|c|c|c|c|c|c|c|c|c|}
\hline Sample & Bottle & Temp & Pump & Sampling & Sampling & Resin & Resin & Temp & \multicolumn{3}{|c|}{ Effluent Bottle Weight, g } & \multicolumn{3}{|c|}{ Sample Vial Weight, g } \\
\hline ID No. & $\begin{array}{l}\text { Size } \\
(\mathrm{mL})\end{array}$ & $\begin{array}{l}\text { Set } \\
\left({ }^{\circ} \mathrm{C}\right)\end{array}$ & $\begin{array}{c}\text { Setting } \\
(\mathrm{mL} / \mathrm{min})\end{array}$ & Start Time & Stop Time & $\begin{array}{c}\text { Height } \\
(\mathrm{cm})\end{array}$ & Color & $\left({ }^{\circ} \mathrm{C}\right)$ & Tare & Gross & Net & Tare & Gross & Net \\
\hline C5-LD-0 & 20 & 30 & NA & $5 / 15 / 126: 41$ & $5 / 15 / 126: 41$ & 1.2 & dark red & 29.9 & NA & NA & NA & 8.45 & 12.82 & 4.37 \\
\hline \multicolumn{4}{|c|}{ Loading (LD) Phase Start Date/Time: } & 5/15/12 6:45 & & & & & & & & & & \\
\hline C5-LD-006 & 20 & 30 & 10.62 & 5/15/12 6:51 & 5/15/12 6:51 & NA & dark red & 29.2 & NA & NA & NA & 8.47 & 12.76 & 4.29 \\
\hline C5-LD-012 & 20 & 30 & 10.62 & $5 / 15 / 126: 57$ & 5/15/12 6:57 & NA & dark red & 29.3 & NA & NA & NA & 8.46 & 12.94 & 4.48 \\
\hline C5-LD-018 & 20 & 30 & 10.62 & 5/15/12 7:03 & 5/15/12 7:03 & NA & dark red & 29.9 & NA & NA & NA & 8.59 & 12.94 & 4.35 \\
\hline C5-LD-024 & 20 & 30 & 10.62 & 5/15/12 7:09 & 5/15/12 7:09 & NA & dark red & 30.2 & NA & NA & NA & 8.71 & 13.17 & 4.46 \\
\hline C5-LD-036 & 20 & 30 & 10.62 & 5/15/12 7:21 & 5/15/12 7:21 & NA & dark red & 30.2 & NA & NA & NA & 8.69 & 12.98 & 4.29 \\
\hline C5-LD-048 & 20 & 30 & 10.62 & 5/15/12 7:33 & 5/15/12 7:33 & NA & dark red & 29.9 & NA & NA & NA & 8.66 & 12.95 & 4.29 \\
\hline C5-LD-060 & 20 & 30 & 10.62 & 5/15/12 7:45 & 5/15/12 7:45 & NA & dark red & 29.9 & NA & NA & NA & 8.54 & 13.35 & 4.81 \\
\hline C5-LD-080 & 20 & 30 & 10.62 & 5/15/12 8:05 & 5/15/12 8:05 & NA & dark red & 29.8 & NA & NA & NA & 8.74 & 13.36 & 4.62 \\
\hline C5-LD-120 & 20 & 30 & 10.62 & 5/15/12 8:45 & 5/15/12 8:45 & NA & dark red & 30.1 & NA & NA & NA & 8.63 & 13.25 & 4.62 \\
\hline C5-LD-180 & 20 & 30 & 10.62 & 5/15/12 9:45 & 5/15/12 9:45 & NA & dark red & 29.6 & NA & NA & NA & 8.57 & 12.86 & 4.29 \\
\hline C5-LD-240 & 20 & 30 & 10.62 & 5/15/12 10:45 & 5/15/12 10:45 & NA & dark red & 29.2 & NA & NA & NA & 8.66 & 13.03 & 4.37 \\
\hline C5-LD-600 & 20 & 30 & 10.62 & 5/15/12 16:46 & 5/15/12 16:46 & NA & dark red & 29.9 & NA & NA & NA & 8.77 & 13.07 & 4.30 \\
\hline C5-FD-CP & 20 & 30 & 0.09 & 5/15/12 17:05 & 5/15/12 19:35 & NA & dark red & 29.8 & 8.79 & 22.40 & 13.61 & NA & NA & NA \\
\hline C5-FDI-CP & 20 & 25 & 0.09 & 5/15/12 19:45 & 5/15/12 21:15 & NA & dark red & 18.8 & 8.62 & 20.38 & 11.76 & NA & NA & NA \\
\hline C5-AN-CP & 20 & 25 & 0.09 & 5/15/12 22:20 & 5/15/12 23:20 & NA & dark red & 18.9 & 8.65 & 13.29 & 4.64 & NA & NA & NA \\
\hline
\end{tabular}

Table A.33. Datasheet for Column C5 Elution, Rinsing, and Regeneration Information

\begin{tabular}{|c|c|c|c|c|c|c|c|c|c|c|c|c|c|c|}
\hline Sample & Bottle & Temp & Pump & Sampling & Sampling & Resin & Resin & Temp & \multicolumn{3}{|c|}{ Effluent Bottle Weight, g } & \multicolumn{3}{|c|}{ Sample Vial Weight, g } \\
\hline ID No. & $\begin{array}{l}\text { Size } \\
(\mathrm{mL})\end{array}$ & $\begin{array}{l}\text { Set } \\
\left({ }^{\circ} \mathrm{C}\right)\end{array}$ & $\begin{array}{c}\text { Setting } \\
\text { (mL/min) }\end{array}$ & Start Time & Stop Time & $\begin{array}{l}\text { Height } \\
(\mathrm{cm})\end{array}$ & Color & $\left({ }^{\circ} \mathrm{C}\right)$ & Tare & Gross & Net & Tare & Gross & Net \\
\hline \multicolumn{4}{|c|}{ Elution (EL) Phase Start Date/Time: } & 5/16/12 7:00 & & & & & & & & & & \\
\hline C5-EL-CP & 60 & 25 & 0.08 & $5 / 16 / 127: 00$ & $5 / 16 / 1217: 00$ & 1.15 & orange & 21.4 & 14.82 & 55.95 & 41.13 & 8.61 & 16.86 & 8.25 \\
\hline C5-EDI-CP & 20 & 25 & 0.09 & 5/16/12 17:15 & 5/16/12 18:15 & 1.15 & orange & 21.3 & 8.67 & 13.30 & 4.63 & NA & NA & NA \\
\hline
\end{tabular}


Table A.34. Datasheet for Column D1 Pretreatment, Loading, and Rinsing Information

\begin{tabular}{|c|c|c|c|c|c|c|c|c|c|c|c|c|c|c|}
\hline \multirow{2}{*}{$\begin{array}{l}\text { Sample } \\
\text { ID No. }\end{array}$} & \multirow{2}{*}{$\begin{array}{c}\text { Bottle } \\
\text { Size } \\
(\mathrm{mL})\end{array}$} & \multirow{2}{*}{$\begin{array}{l}\text { Temp } \\
\text { Set } \\
\left({ }^{\circ} \mathrm{C}\right)\end{array}$} & \multirow{2}{*}{$\begin{array}{c}\text { Pump } \\
\begin{array}{c}\text { Setting } \\
(\mathrm{mL} / \mathrm{min})\end{array}\end{array}$} & \multirow{2}{*}{$\begin{array}{l}\text { Sampling } \\
\text { Start Time }\end{array}$} & \multirow{2}{*}{$\begin{array}{l}\text { Sampling } \\
\text { Stop Time }\end{array}$} & \multirow{2}{*}{$\begin{array}{c}\text { Resin } \\
\begin{array}{c}\text { Height } \\
(\mathrm{cm})\end{array}\end{array}$} & \multirow{2}{*}{$\begin{array}{l}\text { Resin } \\
\text { Color }\end{array}$} & \multirow{2}{*}{$\begin{array}{l}\text { Temp } \\
\left({ }^{\circ} \mathrm{C}\right)\end{array}$} & \multicolumn{3}{|c|}{ Effluent Bottle Weight, g } & \multicolumn{3}{|c|}{ Sample Vial Weight, g } \\
\hline & & & & & & & & & Tare & Gross & Net & Tare & Gross & Net \\
\hline D1-PT-DIW1 & 20 & 25 & 0.09 & 3/26/12 13:05 & $3 / 26 / 12$ 15:35 & 1.30 & dark red & 23.8 & 8.60 & 21.36 & 12.76 & NA & NA & NA \\
\hline D1-PT-DIW2 & 20 & 25 & 0.09 & 3/27/12 13:40 & 3/27/12 14:40 & 1.10 & orange & 23.8 & 8.47 & 13.28 & 4.81 & NA & NA & NA \\
\hline D1-PT-NaOH & 20 & 25 & 0.09 & 3/27/12 14:48 & 3/27/12 17:03 & 1.30 & dark red & 24.1 & 8.50 & 24.53 & 16.03 & NA & NA & NA \\
\hline D1-LD-0 & 20 & 25 & NA & 3/28/12 6:45 & 3/28/12 6:45 & 1.30 & dark red & 25.3 & NA & NA & NA & 8.41 & 12.74 & 4.33 \\
\hline D1-LD-012 & 20 & 25 & 10.62 & 3/28/12 7:00 & 3/28/12 7:00 & NA & dark red & 25.1 & NA & NA & NA & 8.44 & 13.03 & 4.59 \\
\hline D1-LD-018 & 20 & 25 & 10.62 & 3/28/12 7:06 & 3/28/12 7:06 & NA & dark red & 25.0 & NA & NA & NA & 8.49 & 12.94 & 4.45 \\
\hline D1-LD-024 & 20 & 25 & 10.62 & 3/28/12 7:12 & 3/28/12 7:12 & NA & dark red & 24.9 & NA & NA & NA & 8.40 & 12.92 & 4.52 \\
\hline D1-LD-036 & 20 & 25 & 10.62 & 3/28/12 7:24 & 3/28/12 7:24 & NA & dark red & 24.9 & NA & NA & NA & 8.49 & 13.72 & 5.23 \\
\hline D1-LD-048 & 20 & 25 & 10.62 & 3/28/12 7:36 & 3/28/12 7:36 & NA & dark red & 24.8 & NA & NA & NA & 8.48 & 13.00 & 4.52 \\
\hline D1-LD-060 & 20 & 25 & 10.62 & 3/28/12 7:48 & 3/28/12 7:48 & NA & dark red & 25.0 & NA & NA & NA & 8.56 & 12.75 & 4.19 \\
\hline D1-LD-600 & 20 & 25 & 10.62 & 3/28/12 16:48 & 3/28/12 16:48 & 1.30 & dark red & 25.0 & NA & NA & NA & 8.45 & 13.06 & 4.61 \\
\hline D1-FD-CP & 20 & 25 & 0.09 & 3/28/12 17:00 & $3 / 28 / 12$ 19:30 & 1.30 & dark red & 25.8 & 8.37 & 22.69 & 14.32 & NA & NA & NA \\
\hline D1-FDI-CP & 20 & 25 & 0.09 & 3/28/12 19:37 & 3/28/12 22:07 & 1.30 & dark red & 24.7 & 8.38 & 21.09 & 12.71 & NA & NA & NA \\
\hline D1-AN-CP & 20 & 25 & 0.09 & 3/28/12 22:12 & 3/28/12 23:12 & 1.30 & dark red & 24.6 & 8.46 & 13.64 & 5.18 & NA & NA & NA \\
\hline
\end{tabular}


Table A.35. Datasheet for Column D1 Elution, Rinsing, and Regeneration Information

\begin{tabular}{|c|c|c|c|c|c|c|c|c|c|c|c|c|c|c|}
\hline Sample & Bottle & Temp & Pump & Sampling & Sampling & Resin & Resin & Temp & \multicolumn{3}{|c|}{ Effluent Bottle Weight, g } & \multicolumn{3}{|c|}{ Sample Vial Weight, g } \\
\hline ID No. & $\begin{array}{l}\text { Size } \\
(\mathrm{mL})\end{array}$ & $\begin{array}{c}\text { Set } \\
\left({ }^{\circ} \mathrm{C}\right) \\
\end{array}$ & $\begin{array}{c}\text { Setting } \\
(\mathrm{mL} / \mathrm{min})\end{array}$ & Start Time & Stop Time & $\begin{array}{c}\text { Height } \\
(\mathrm{cm})\end{array}$ & Color & $\left({ }^{\circ} \mathrm{C}\right)$ & Tare & Gross & Net & Tare & Gross & Net \\
\hline \multicolumn{4}{|c|}{ Elution (EL) Phase Start Date/Time: } & 3/29/12 6:37 & & & & & & & & & & \\
\hline D1-EL-CP & 60 & 25 & 0.08 & 3/29/12 6:37 & 3/29/12 16:37 & 1.30 & orange & 24.8 & 14.62 & 59.76 & 45.14 & 8.38 & 16.32 & 7.94 \\
\hline D1-EDI-CP & 20 & 25 & 0.09 & 3/29/12 16:43 & 3/29/12 17:43 & 1.10 & orange & 24.3 & 8.47 & 13.45 & 4.98 & NA & NA & NA \\
\hline D1-RG-CP & 20 & 25 & 0.09 & 3/29/12 18:00 & 3/29/12 20:30 & 1.30 & dark red & 24.0 & 8.49 & 20.93 & 12.44 & NA & NA & NA \\
\hline
\end{tabular}

Table A.36. Datasheet for Column D2 Loading and Rinsing Information

\begin{tabular}{|c|c|c|c|c|c|c|c|c|c|c|c|c|c|c|}
\hline Sample & Bottle & Temp & Pump & Sampling & Sampling & Resin & Resin & Temp & \multicolumn{3}{|c|}{ Effluent Bottle Weight, g } & \multicolumn{3}{|c|}{ Sample Vial Weight, g } \\
\hline ID No. & $\begin{array}{l}\text { Size } \\
(\mathrm{mL})\end{array}$ & $\begin{array}{l}\text { Set } \\
\left({ }^{\circ} \mathrm{C}\right)\end{array}$ & $\begin{array}{c}\text { Setting } \\
\text { (mL/min) }\end{array}$ & Start Time & Stop Time & $\begin{array}{c}\text { Height } \\
(\mathrm{cm})\end{array}$ & Color & $\left({ }^{\circ} \mathrm{C}\right)$ & Tare & Gross & Net & Tare & Gross & Net \\
\hline D2-LD-0 & 20 & 25 & NA & 4/2/12 6:28 & 4/2/12 6:28 & 1.10 & dark red & 25.6 & NA & NA & NA & 8.41 & 13.06 & 4.65 \\
\hline \multicolumn{4}{|c|}{ Loading (LD) Phase Start Date/Time: } & 4/2/12 6:33 & & & & & & & & & & \\
\hline D2-LD-006 & 20 & 25 & 14.16 & 4/2/12 6:39 & 4/2/12 6:39 & NA & dark red & 25.3 & NA & NA & NA & 8.49 & 12.84 & 4.35 \\
\hline D2-LD-012 & 20 & 25 & 14.16 & 4/2/12 6:45 & 4/2/12 6:45 & NA & dark red & 25.2 & NA & NA & NA & 8.51 & 13.02 & 4.51 \\
\hline D2-LD-018 & 20 & 25 & 14.16 & $4 / 2 / 126: 51$ & $4 / 2 / 126: 51$ & NA & dark red & 25.2 & NA & NA & NA & 8.45 & 13.24 & 4.79 \\
\hline D2-LD-024 & 20 & 25 & 14.16 & $4 / 2 / 126: 57$ & 4/2/12 6:57 & NA & dark red & 25.2 & NA & NA & NA & 8.49 & 13.02 & 4.53 \\
\hline D2-LD-036 & 20 & 25 & 14.16 & 4/2/12 7:09 & 4/2/12 7:09 & NA & dark red & 25.0 & NA & NA & NA & 8.43 & 12.99 & 4.56 \\
\hline D2-LD-048 & 20 & 25 & 14.16 & $4 / 2 / 127: 21$ & $4 / 2 / 127: 21$ & NA & dark red & 24.9 & NA & NA & NA & 8.43 & 13.11 & 4.68 \\
\hline D2-LD-060 & 20 & 25 & 14.16 & 4/2/12 7:33 & 4/2/12 7:33 & NA & dark red & 25.0 & NA & NA & NA & 8.40 & 12.98 & 4.58 \\
\hline D2-LD-080 & 20 & 25 & 14.16 & 4/2/12 7:53 & 4/2/12 7:53 & NA & dark red & 24.9 & NA & NA & NA & 8.34 & 12.75 & 4.41 \\
\hline D2-LD-120 & 20 & 25 & 14.16 & 4/2/12 8:33 & 4/2/12 8:33 & NA & dark red & 24.9 & NA & NA & NA & 8.38 & 12.98 & 4.60 \\
\hline D2-LD-180 & 20 & 25 & 14.16 & 4/2/12 9:33 & 4/2/12 9:33 & NA & dark red & 24.8 & NA & NA & NA & 8.46 & 13.18 & 4.72 \\
\hline D2-LD-240 & 20 & 25 & 14.16 & 4/2/12 10:33 & 4/2/12 10:33 & NA & dark red & 24.9 & NA & NA & NA & 8.48 & 13.20 & 4.72 \\
\hline D2-LD-600 & 20 & 25 & 14.16 & 4/2/12 16:33 & 4/2/12 16:33 & NA & dark red & 24.8 & NA & NA & NA & 8.42 & 13.10 & 4.68 \\
\hline D2-FD-CP & 20 & 25 & 0.09 & 4/2/12 16:42 & 4/2/12 19:12 & NA & dark red & 25.4 & 8.42 & 22.28 & 13.86 & NA & NA & NA \\
\hline D2-FDI-CP & 20 & 25 & 0.09 & 4/2/12 19:20 & 4/2/12 21:50 & NA & dark red & 24.0 & 8.46 & 20.92 & 12.46 & NA & NA & NA \\
\hline D2-AN-CP & 20 & 25 & 0.09 & 4/2/12 21:54 & $4 / 2 / 1222: 54$ & 1.10 & dark red & 24.1 & 8.52 & 13.37 & 4.85 & NA & NA & NA \\
\hline
\end{tabular}


Table A.37. Datasheet for Column D2 Elution, Rinsing, and Regeneration Information

\begin{tabular}{|c|c|c|c|c|c|c|c|c|c|c|c|c|c|c|}
\hline Sample & Bottle & Temp & Pump & Sampling & Sampling & Resin & Resin & Temp & \multicolumn{3}{|c|}{ Effluent Bottle Weight, g } & \multicolumn{3}{|c|}{ Sample Vial Weight, g } \\
\hline ID No. & $\begin{array}{l}\text { Size } \\
(\mathrm{mL})\end{array}$ & $\begin{array}{l}\text { Set } \\
\left({ }^{\circ} \mathrm{C}\right)\end{array}$ & $\begin{array}{c}\text { Setting } \\
(\mathrm{mL} / \mathrm{min})\end{array}$ & Start Time & Stop Time & $\begin{array}{l}\text { Height } \\
(\mathrm{cm})\end{array}$ & Color & $\left({ }^{\circ} \mathrm{C}\right)$ & Tare & Gross & Net & Tare & Gross & Net \\
\hline \multicolumn{4}{|c|}{ Elution (EL) } & 4/3/12 6:22 & & & & & & & & & & \\
\hline D2-EL-CP & 60 & 25 & 0.08 & 4/3/12 6:22 & 4/3/12 16:22 & 1.10 & orange & 24.4 & 14.69 & 57.74 & 43.05 & 8.36 & 16.98 & 8.62 \\
\hline D2-EDI-CP & 20 & 25 & 0.09 & 4/3/12 16:30 & $4 / 3 / 1217: 30$ & 1.10 & orange & 24.2 & 8.40 & 13.32 & 4.92 & NA & NA & NA \\
\hline D2-RG-CP & 20 & 25 & 0.09 & 4/3/12 17:35 & 4/3/12 20:05 & 1.30 & dark red & 24.0 & 8.48 & 20.48 & 12.00 & NA & NA & NA \\
\hline
\end{tabular}

Table A.38. Datasheet for Column D3 Loading and Rinsing Information

\begin{tabular}{|c|c|c|c|c|c|c|c|c|c|c|c|c|c|c|}
\hline Sample & Bottle & Temp & Pump & Sampling & Sampling & Resin & Resin & Temp & \multicolumn{3}{|c|}{ Effluent Bottle Weight, g } & \multicolumn{3}{|c|}{ Sample Vial Weight, g } \\
\hline ID No. & $\begin{array}{l}\text { Size } \\
(\mathrm{mL})\end{array}$ & $\begin{array}{l}\text { Set } \\
\left({ }^{\circ} \mathrm{C}\right) \\
\end{array}$ & $\begin{array}{c}\text { Setting } \\
\text { (mL/min) }\end{array}$ & Start Time & Stop Time & $\begin{array}{l}\text { Height } \\
\text { (cm) }\end{array}$ & Color & $\left({ }^{\circ} \mathrm{C}\right)$ & Tare & Gross & Net & Tare & Gross & Net \\
\hline D3-LD-0 & 20 & 25 & NA & 4/4/12 6:34 & $4 / 4 / 126: 34$ & 1.25 & dark red & 25.5 & NA & NA & NA & 8.44 & 13.33 & 4.89 \\
\hline \multicolumn{2}{|c|}{ Loading (LD) } & Phase Sta & Date/Time: & 4/4/12 6:38 & & & & & & & & & & \\
\hline D3-LD-006 & 20 & 25 & 7.08 & $4 / 4 / 126: 44$ & 4/4/12 6:44 & NA & dark red & 25.2 & NA & NA & NA & 8.48 & 13.31 & 4.83 \\
\hline D3-LD-012 & 20 & 25 & 7.08 & 4/4/12 6:50 & 4/4/12 6:50 & NA & dark red & 25.1 & NA & NA & NA & 8.56 & 13.20 & 4.64 \\
\hline D3-LD-018 & 20 & 25 & 7.08 & 4/4/12 6:56 & 4/4/12 6:56 & NA & dark red & 25.0 & NA & NA & NA & 8.49 & 13.05 & 4.56 \\
\hline D3-LD-024 & 20 & 25 & 7.08 & 4/4/12 7:02 & 4/4/12 7:02 & NA & dark red & 25.0 & NA & NA & NA & 8.54 & 13.26 & 4.72 \\
\hline D3-LD-036 & 20 & 25 & 7.08 & 4/4/12 7:14 & 4/4/12 7:14 & NA & dark red & 24.9 & NA & NA & NA & 8.55 & 12.99 & 4.44 \\
\hline D3-LD-048 & 20 & 25 & 7.08 & 4/4/12 7:26 & 4/4/12 7:26 & NA & dark red & 24.9 & NA & NA & NA & 8.50 & 13.40 & 4.90 \\
\hline D3-LD-060 & 20 & 25 & 7.08 & 4/4/12 7:38 & $4 / 4 / 12$ 7:38 & NA & dark red & 24.8 & NA & NA & NA & 8.53 & 13.19 & 4.66 \\
\hline D3-LD-080 & 20 & 25 & 7.08 & 4/4/12 7:58 & $4 / 4 / 12$ 7:58 & NA & dark red & 24.9 & NA & NA & NA & 8.58 & 13.42 & 4.84 \\
\hline D3-LD-120 & 20 & 25 & 7.08 & 4/4/12 8:38 & 4/4/12 8:38 & NA & dark red & 24.9 & NA & NA & NA & 8.57 & 13.24 & 4.67 \\
\hline D3-LD-180 & 20 & 25 & 7.08 & 4/4/12 9:38 & 4/4/12 9:38 & NA & dark red & 24.8 & NA & NA & NA & 8.48 & 13.26 & 4.78 \\
\hline D3-LD-240 & 20 & 25 & 7.08 & 4/4/12 10:38 & 4/4/12 10:38 & NA & dark red & 24.9 & NA & NA & NA & 8.47 & 12.81 & 4.34 \\
\hline D3-LD-600 & 20 & 25 & 7.08 & 4/4/12 16:38 & 4/4/12 16:38 & NA & dark red & 25.0 & NA & NA & NA & 8.62 & 13.14 & 4.52 \\
\hline D3-FD-CP & 20 & 25 & 0.09 & 4/4/12 16:47 & 4/4/12 19:17 & NA & dark red & 25.8 & 8.47 & 22.51 & 14.04 & NA & NA & NA \\
\hline D3-FDI-CP & 20 & 25 & 0.09 & 4/4/12 19:22 & 4/4/12 21:52 & NA & dark red & 26.1 & 8.50 & 21.14 & 12.64 & NA & NA & NA \\
\hline D3-AN-CP & 20 & 25 & 0.09 & 4/4/12 21:56 & 4/4/12 22:56 & 1.25 & dark red & 24.9 & 8.49 & 13.34 & 4.85 & NA & NA & NA \\
\hline
\end{tabular}


Table A.39. Datasheet for Column C3 Elution, Rinsing, and Regeneration Information

\begin{tabular}{|c|c|c|c|c|c|c|c|c|c|c|c|c|c|c|}
\hline \multirow{2}{*}{$\begin{array}{l}\text { Sample } \\
\text { ID No. }\end{array}$} & \multirow{2}{*}{$\begin{array}{l}\text { Bottle } \\
\text { Size } \\
(\mathrm{mL})\end{array}$} & \multirow{2}{*}{$\begin{array}{l}\text { Temp } \\
\text { Set } \\
\left({ }^{\circ} \mathrm{C}\right)\end{array}$} & \multirow{2}{*}{$\begin{array}{c}\text { Pump } \\
\text { Setting } \\
\text { (mL/min) }\end{array}$} & \multirow{2}{*}{$\begin{array}{l}\text { Sampling } \\
\text { Start Time }\end{array}$} & \multirow{2}{*}{$\begin{array}{l}\text { Sampling } \\
\text { Stop Time }\end{array}$} & \multirow{2}{*}{$\begin{array}{l}\text { Resin } \\
\text { Height } \\
\text { (cm) }\end{array}$} & \multirow{2}{*}{$\begin{array}{l}\text { Resin } \\
\text { Color }\end{array}$} & \multirow{2}{*}{$\begin{array}{l}\text { Temp } \\
\left({ }^{\circ} \mathrm{C}\right)\end{array}$} & \multicolumn{3}{|c|}{ Effluent Bottle Weight, g } & \multicolumn{3}{|c|}{ Sample Vial Weight, g } \\
\hline & & & & & & & & & Tare & Gross & Net & Tare & Gross & Net \\
\hline \multicolumn{2}{|c|}{ Elution (EL) } & Phase Sta & Date/Time: & 4/5/12 6:28 & & & & & & & & & & \\
\hline D3-EL-CP & 60 & 25 & 0.08 & 4/5/12 6:28 & 4/5/12 16:28 & 1.10 & orange & 25.0 & 14.90 & 59.45 & 44.55 & 8.46 & 18.41 & 9.95 \\
\hline D3-EDI-CP & 20 & 25 & 0.09 & 4/5/12 16:45 & 4/5/12 17:45 & 1.10 & orange & 24.2 & 8.49 & 13.45 & 4.96 & NA & NA & NA \\
\hline D3-RG-CP & 20 & 25 & 0.09 & 4/5/12 17:50 & 4/5/12 20:20 & 1.30 & dark red & 24.7 & 8.43 & 20.81 & 12.38 & NA & NA & NA \\
\hline
\end{tabular}

Table A.40. Datasheet for Column D4 Loading and Rinsing Information

\begin{tabular}{|c|c|c|c|c|c|c|c|c|c|c|c|c|c|c|}
\hline Sample & Bottle & Temp & Pump & Sampling & Sampling & Resin & Resin & Temp & \multicolumn{3}{|c|}{ Effluent Bottle Weight, g } & \multicolumn{3}{|c|}{ Sample Vial Weight, g } \\
\hline ID No. & $\begin{array}{l}\text { Size } \\
(\mathrm{mL})\end{array}$ & $\begin{array}{l}\text { Set } \\
\left({ }^{\circ} \mathrm{C}\right)\end{array}$ & $\begin{array}{l}\text { Setting } \\
\text { (mL/min) }\end{array}$ & Start Time & Stop Time & $\begin{array}{l}\text { Height } \\
\text { (cm) }\end{array}$ & Color & $\left({ }^{\circ} \mathrm{C}\right)$ & Tare & Gross & Net & Tare & Gross & Net \\
\hline D4-LD-0 & 20 & 25 & NA & 4/9/12 6:41 & $4 / 9 / 126: 41$ & 1.25 & dark red & 25.9 & NA & NA & NA & 8.52 & 13.30 & 4.78 \\
\hline \multicolumn{2}{|c|}{ Loading (LD) } & hase Sta & Date/Time: & 4/9/12 6:43 & & & & & & & & & & \\
\hline D4-LD-006 & 20 & 25 & 10.62 & 4/9/12 6:49 & 4/9/12 6:49 & NA & dark red & 25.6 & NA & NA & NA & 8.49 & 13.27 & 4.78 \\
\hline D4-LD-012 & 20 & 25 & 10.62 & 4/9/12 6:55 & 4/9/12 6:55 & NA & dark red & 25.5 & NA & NA & NA & 8.55 & 13.25 & 4.70 \\
\hline D4-LD-018 & 20 & 25 & 10.62 & 4/9/12 7:01 & 4/9/12 7:01 & NA & dark red & 25.3 & NA & NA & NA & 8.50 & 13.29 & 4.79 \\
\hline D4-LD-024 & 20 & 25 & 10.62 & 4/9/12 7:07 & 4/9/12 7:07 & NA & dark red & 25.3 & NA & NA & NA & 8.43 & 13.09 & 4.66 \\
\hline D4-LD-036 & 20 & 25 & 10.62 & 4/9/12 7:20 & 4/9/12 7:20 & NA & dark red & 25.1 & NA & NA & NA & 8.45 & 13.16 & 4.71 \\
\hline D4-LD-048 & 20 & 25 & 10.62 & 4/9/12 7:31 & 4/9/12 7:31 & NA & dark red & 25.1 & NA & NA & NA & 8.47 & 13.13 & 4.66 \\
\hline D4-LD-060 & 20 & 25 & 10.62 & 4/9/12 7:43 & 4/9/12 7:43 & NA & dark red & 25.0 & NA & NA & NA & 8.56 & 13.46 & 4.90 \\
\hline D4-LD-080 & 20 & 25 & 10.62 & 4/9/12 8:03 & 4/9/12 8:03 & NA & dark red & 25.0 & NA & NA & NA & 8.45 & 13.19 & 4.74 \\
\hline D4-LD-120 & 20 & 25 & 10.62 & 4/9/12 8:43 & 4/9/12 8:43 & NA & dark red & 24.9 & NA & NA & NA & 8.48 & 13.35 & 4.87 \\
\hline D4-LD-180 & 20 & 25 & 10.62 & 4/9/12 9:43 & 4/9/12 9:43 & NA & dark red & 24.9 & NA & NA & NA & 8.48 & 13.32 & 4.84 \\
\hline D4-LD-240 & 20 & 25 & 10.62 & 4/9/12 10:43 & 4/9/12 10:43 & NA & dark red & 25.0 & NA & NA & NA & 8.44 & 13.08 & 4.64 \\
\hline D4-LD-600 & 20 & 25 & 10.62 & 4/9/12 16:43 & 4/9/12 16:43 & NA & dark red & 25.3 & NA & NA & NA & 8.35 & 13.15 & 4.80 \\
\hline D4-FD-CP & 20 & 25 & 0.09 & 4/9/12 17:03 & 4/9/12 19:33 & NA & dark red & 24.9 & 8.46 & 23.20 & 14.74 & NA & NA & NA \\
\hline D4-FDI-CP & 20 & 25 & 0.09 & 4/9/12 19:36 & 4/9/12 22:06 & NA & dark red & 24.8 & 8.47 & 21.58 & 13.11 & NA & NA & NA \\
\hline
\end{tabular}


Table A.41. Datasheet for Column D4B Loading and Rinsing Information

\begin{tabular}{|c|c|c|c|c|c|c|c|c|c|c|c|c|c|c|}
\hline \multirow{2}{*}{$\begin{array}{l}\text { Sample } \\
\text { ID No. }\end{array}$} & \multirow{2}{*}{$\begin{array}{c}\text { Bottle } \\
\text { Size } \\
(\mathrm{mL})\end{array}$} & \multirow{2}{*}{$\begin{array}{c}\text { Temp } \\
\text { Set } \\
\left({ }^{\circ} \mathrm{C}\right)\end{array}$} & \multirow{2}{*}{$\begin{array}{c}\text { Pump } \\
\begin{array}{c}\text { Setting } \\
\text { (mL/min) }\end{array}\end{array}$} & \multirow{2}{*}{$\begin{array}{l}\text { Sampling } \\
\text { Start Time }\end{array}$} & \multirow{2}{*}{$\begin{array}{l}\text { Sampling } \\
\text { Stop Time }\end{array}$} & \multirow{2}{*}{$\begin{array}{c}\text { Resin } \\
\text { Height } \\
(\mathrm{cm})\end{array}$} & \multirow{2}{*}{$\begin{array}{l}\text { Resin } \\
\text { Color }\end{array}$} & \multirow{2}{*}{$\begin{array}{l}\text { Temp } \\
\left({ }^{\circ} \mathrm{C}\right)\end{array}$} & \multicolumn{3}{|c|}{ Effluent Bottle Weight, g } & \multicolumn{3}{|c|}{ Sample Vial Weight, g } \\
\hline & & & & & & & & & Tare & Gross & Net & Tare & Gross & Net \\
\hline D4B-LD-0 & 20 & 45 & NA & 4/11/12 8:57 & 4/11/12 8:57 & 1.15 & dark red & 45.1 & NA & NA & NA & 8.51 & 13.12 & 4.61 \\
\hline \multicolumn{4}{|c|}{ Loading (LD) Phase Start Date/Time: } & 4/11/12 9:03 & & & & & & & & & & \\
\hline D4B-LD-004 & 20 & 45 & 0.08 & 4/11/12 13:16 & 4/11/12 13:16 & NA & dark red & 45.0 & NA & NA & NA & 8.54 & 12.94 & 4.40 \\
\hline D4B-LD-008 & 20 & 45 & 0.08 & 4/11/12 17:12 & 4/11/12 17:12 & NA & dark red & 45.0 & NA & NA & NA & 8.57 & 13.06 & 4.49 \\
\hline D4B-LD-012 & 20 & 45 & 0.08 & 4/11/12 21:03 & 4/11/12 21:03 & NA & dark red & 45.0 & NA & NA & NA & 8.52 & 12.91 & 4.39 \\
\hline D4B-LD-024 & 20 & 45 & 0.08 & 4/12/12 9:03 & 4/12/12 9:03 & NA & dark red & 45.0 & NA & NA & NA & 8.61 & 13.09 & 4.48 \\
\hline D4B-LD-072 & 20 & 45 & 0.08 & 4/14/12 9:03 & 4/14/12 9:03 & NA & $\begin{array}{l}\text { almost } \\
\text { black }\end{array}$ & 44.8 & NA & NA & NA & 8.51 & 13.10 & 4.59 \\
\hline D4B-LD-120 & 20 & 45 & 0.08 & 4/16/12 9:03 & 4/16/12 9:03 & NA & dark red & 44.7 & NA & NA & NA & 8.59 & 13.00 & 4.41 \\
\hline D4B-LD-168 & 20 & 45 & 0.08 & 4/18/12 9:03 & 4/18/12 9:03 & NA & dark red & 44.8 & NA & NA & NA & 8.59 & 13.14 & 4.55 \\
\hline D4B-LD-336 & 20 & 45 & 0.08 & 4/25/12 9:03 & 4/25/12 9:03 & NA & dark red & 44.6 & NA & NA & NA & 8.54 & 13.15 & 4.61 \\
\hline D4B-LD-504 & 20 & 45 & 0.08 & 5/2/12 9:03 & 5/2/12 9:03 & NA & dark red & 44.0 & NA & NA & NA & 8.43 & 12.96 & 4.53 \\
\hline D4B-LD-672 & 20 & 45 & 0.08 & 5/9/12 9:03 & 5/9/12 9:03 & NA & dark red & 45.8 & NA & NA & NA & 8.61 & 13.34 & 4.73 \\
\hline D4B-LD-720 & 20 & 45 & 0.08 & 5/11/12 9:10 & 5/11/12 9:10 & NA & dark red & 44.3 & NA & NA & NA & 8.51 & 13.35 & 4.84 \\
\hline D4B-FD-CP & 20 & 45 & 0.09 & 5/11/12 9:37 & 5/11/12 12:07 & NA & dark red & 45.1 & 8.64 & 23.45 & 14.81 & NA & NA & NA \\
\hline D4B-FDI-CP & 20 & 25 & 0.09 & 5/11/12 13:25 & $5 / 11 / 1215: 55$ & 1.15 & dark red & 22.6 & 8.59 & 21.70 & 13.11 & NA & NA & NA \\
\hline D4B-AN-CP & 20 & 25 & 0.09 & 5/11/12 16:00 & $5 / 11 / 1217: 00$ & 1.15 & dark red & 22.7 & 8.52 & 13.07 & 4.55 & NA & NA & NA \\
\hline
\end{tabular}

Table A.42. Datasheet for Column D4B Elution, Rinsing, and Regeneration Information

\begin{tabular}{|c|c|c|c|c|c|c|c|c|c|c|c|c|c|c|}
\hline Sample & Bottle & Temp & Pump & Sampling & Sampling & Resin & Resin & Temp & \multicolumn{3}{|c|}{ Effluent Bottle Weight, g } & \multicolumn{3}{|c|}{ Sample Vial Weight, g } \\
\hline ID No. & $\begin{array}{l}\text { Size } \\
(\mathrm{mL})\end{array}$ & $\begin{array}{l}\text { Set } \\
\left({ }^{\circ} \mathrm{C}\right)\end{array}$ & $\begin{array}{l}\text { Setting } \\
\text { (mL/min) }\end{array}$ & Start Time & Stop Time & $\begin{array}{l}\text { Height } \\
(\mathrm{cm})\end{array}$ & Color & $\left({ }^{\circ} \mathrm{C}\right)$ & Tare & Gross & Net & Tare & Gross & Net \\
\hline \multicolumn{4}{|c|}{ Elution (EL) Phase Start Date/Time: } & 5/14/12 6:55 & & & & & & & & & & \\
\hline D4B-EL-CP & 60 & 25 & 0.08 & 5/14/12 6:55 & $5 / 14 / 1216: 55$ & 1.15 & orange & 19.8 & 14.85 & 60.83 & 45.98 & 8.48 & 16.69 & 8.21 \\
\hline D4B-EDI-CP & 20 & 25 & 0.09 & 5/14/12 17:32 & 5/14/12 18:32 & 1.15 & orange & 20.4 & 8.52 & 13.35 & 4.83 & NA & NA & NA \\
\hline D4B-RG-CP & 20 & 25 & 0.09 & 5/14/12 18:49 & 5/14/12 21:19 & 1.15 & dark red & 20.3 & 8.45 & 20.83 & 12.38 & NA & NA & NA \\
\hline
\end{tabular}


Table A.43. Datasheet for Column D5 Loading and Rinsing Information

\begin{tabular}{|c|c|c|c|c|c|c|c|c|c|c|c|c|c|c|}
\hline Sample & Bottle & Temp & Pump & Sampling & Sampling & Resin & Resin & Temp & \multicolumn{3}{|c|}{ Effluent Bottle Weight, g } & \multicolumn{3}{|c|}{ Sample Vial Weight, g } \\
\hline ID No. & $\begin{array}{l}\text { Size } \\
(\mathrm{mL})\end{array}$ & Set $\left({ }^{\circ} \mathrm{C}\right)$ & $\begin{array}{c}\text { Setting } \\
\text { (mL/min) }\end{array}$ & Start Time & Stop Time & $\begin{array}{l}\text { Height } \\
(\mathrm{cm})\end{array}$ & Color & $\left({ }^{\circ} \mathrm{C}\right)$ & Tare & Gross & Net & Tare & Gross & Net \\
\hline D5-LD-0 & 20 & 25 & NA & $5 / 15 / 126: 43$ & $5 / 15 / 126: 43$ & 1.15 & dark red & 23.2 & NA & NA & NA & 8.50 & 12.99 & 4.49 \\
\hline \multicolumn{2}{|c|}{ Loading (LD) } & Phase Sta & Date/Time: & $5 / 15 / 12$ 6:48 & & & & & & & & & & \\
\hline D5-LD-006 & 20 & 25 & 10.62 & 5/15/12 6:54 & 5/15/12 6:54 & NA & dark red & 23.8 & NA & NA & NA & 8.51 & 12.73 & 4.22 \\
\hline D5-LD-012 & 20 & 25 & 10.62 & 5/15/12 7:00 & 5/15/12 7:00 & NA & dark red & 24.5 & NA & NA & NA & 8.55 & 12.09 & 3.54 \\
\hline D5-LD-018 & 20 & 25 & 10.62 & 5/15/12 7:06 & 5/15/12 7:06 & NA & dark red & 25.0 & NA & NA & NA & 8.48 & 13.07 & 4.59 \\
\hline D5-LD-024 & 20 & 25 & 10.62 & 5/15/12 7:12 & 5/15/12 7:12 & NA & dark red & 25.3 & NA & NA & NA & 8.53 & 13.20 & 4.67 \\
\hline D5-LD-036 & 20 & 25 & 10.62 & 5/15/12 7:24 & 5/15/12 7:24 & NA & dark red & 25.3 & NA & NA & NA & 8.46 & 13.18 & 4.72 \\
\hline D5-LD-048 & 20 & 25 & 10.62 & 5/15/12 7:36 & 5/15/12 7:36 & NA & dark red & 24.9 & NA & NA & NA & 8.60 & 12.76 & 4.16 \\
\hline D5-LD-060 & 20 & 25 & 10.62 & 5/15/12 7:48 & 5/15/12 7:48 & NA & dark red & 24.8 & NA & NA & NA & 8.45 & 13.12 & 4.67 \\
\hline D5-LD-080 & 20 & 25 & 10.62 & 5/15/12 8:08 & 5/15/12 8:08 & NA & dark red & 24.8 & NA & NA & NA & 8.62 & 13.14 & 4.52 \\
\hline D5-LD-120 & 20 & 25 & 10.62 & 5/15/12 8:48 & 5/15/12 8:48 & NA & dark red & 25.1 & NA & NA & NA & 8.39 & 13.21 & 4.82 \\
\hline D5-LD-180 & 20 & 25 & 10.62 & 5/15/12 9:48 & 5/15/12 9:48 & NA & dark red & 24.7 & NA & NA & NA & 8.55 & 13.09 & 4.54 \\
\hline D5-LD-240 & 20 & 25 & 10.62 & 5/15/12 10:48 & 5/15/12 10:48 & NA & dark red & 24.3 & NA & NA & NA & 8.56 & 12.72 & 4.16 \\
\hline D5-LD-600 & 20 & 25 & 10.62 & 5/15/12 16:48 & 5/15/12 16:48 & NA & dark red & 24.9 & NA & NA & NA & 8.65 & 13.28 & 4.63 \\
\hline D5-FD-CP & 20 & 25 & 0.09 & 5/15/12 17:05 & 5/15/12 19:35 & NA & dark red & 25.5 & 8.40 & 22.97 & 14.57 & NA & NA & NA \\
\hline D5-FDI-CP & 20 & 25 & 0.09 & 5/15/12 19:45 & 5/15/12 21:15 & NA & dark red & 18.9 & 8.46 & 21.20 & 12.74 & NA & NA & NA \\
\hline D5-AN-CP & 20 & 25 & 0.09 & 5/15/12 22:20 & 5/15/12 23:20 & NA & dark red & 19.0 & 8.58 & 13.59 & 5.01 & NA & NA & NA \\
\hline
\end{tabular}

Table A.44. Datasheet for Column D5 Elution, Rinsing, and Regeneration Information

\begin{tabular}{|c|c|c|c|c|c|c|c|c|c|c|c|c|c|c|}
\hline Sample & Bottle & Temp & Pump & Sampling & Sampling & Resin & Resin & Temp & \multicolumn{3}{|c|}{ Effluent Bottle Weight, g } & \multicolumn{3}{|c|}{ Sample Vial Weight, g } \\
\hline ID No. & $\begin{array}{l}\text { Size } \\
(\mathrm{mL})\end{array}$ & $\begin{array}{l}\text { Set } \\
\left({ }^{\circ} \mathrm{C}\right)\end{array}$ & $\begin{array}{c}\text { Setting } \\
(\mathrm{mL} / \mathrm{min})\end{array}$ & Start Time & Stop Time & $\begin{array}{l}\text { Height } \\
(\mathrm{cm})\end{array}$ & Color & $\left({ }^{\circ} \mathrm{C}\right)$ & Tare & Gross & Net & Tare & Gross & Net \\
\hline \multicolumn{4}{|c|}{ Elution (EL) Phase Start Date/Time: } & $5 / 16 / 12$ 7:00 & & & & & & & & & & \\
\hline D5-EL-CP & 60 & 25 & 0.08 & 5/16/12 7:00 & 5/16/12 17:00 & 1.1 & orange & 20.2 & 14.82 & 58.69 & 43.87 & 8.45 & 15.78 & 7.33 \\
\hline D5-EDI-CP & 20 & 25 & 0.08 & 5/16/12 17:15 & 5/16/12 18:15 & 1.1 & orange & 20.1 & 8.50 & 13.45 & 4.95 & NA & NA & NA \\
\hline
\end{tabular}


Table A.45. Datasheet for $50^{\circ} \mathrm{C}$ Batch Loading Tests

\begin{tabular}{|c|c|c|c|c|c|c|c|c|c|c|}
\hline Sample & $\begin{array}{c}\text { Simulant ID } \\
\text { Used }\end{array}$ & $\begin{array}{l}\text { Resin } \\
\text { Added }\end{array}$ & $\begin{array}{l}\text { Simulant } \\
\text { Added }\end{array}$ & Resin Added & $\begin{array}{c}\text { Temp When } \\
\text { Added }\end{array}$ & Resin Removed & $\begin{array}{c}\text { Temp When } \\
\text { Removed }\end{array}$ & \multicolumn{3}{|c|}{ Sample Vial Weight, g } \\
\hline ID No. & & (g) & (g) & Date/Time & $\left({ }^{\circ} \mathrm{C}\right)$ & Date/Time & $\left({ }^{\circ} \mathrm{C}\right)$ & Tare & Gross & Net \\
\hline Test-5-Na-LL-1 & 1 & 0.2189 & 24.8113 & 3/16/12 9:12 & 49.5 & 3/19/12 9:12 & 50.0 & 8.48 & 14.13 & 5.65 \\
\hline Test-5-Na-LL-2 & 2 & 0.2204 & 25.5372 & 3/16/12 9:14 & 49.5 & 3/19/12 9:14 & 50.0 & 8.53 & 14.22 & 5.69 \\
\hline Test-5-Na-LL-3 & 3 & 0.2205 & 25.8469 & 3/16/12 9:16 & 49.8 & 3/19/12 9:16 & 50.1 & 8.38 & 14.29 & 5.91 \\
\hline Test-5-Na-LL-4 & 4 & 0.2206 & 26.1507 & 3/16/12 9:18 & 49.6 & 3/19/12 9:18 & 50.2 & 8.51 & 14.39 & 5.88 \\
\hline Test-5-Na-LL-5 & 5 & 0.2219 & 28.7257 & 3/16/12 9:21 & 49.8 & 3/19/12 9:21 & 50.3 & 8.51 & 14.65 & 6.14 \\
\hline Test-5-Na-LL-6 & 6 & 0.2193 & 31.3679 & 3/16/12 9:23 & 49.9 & 3/19/12 9:23 & 50.0 & 8.40 & 15.21 & 6.81 \\
\hline Test-5-Na-MM-1 & 7 & 0.2220 & 25.0646 & 3/16/12 9:27 & 49.4 & $3 / 19 / 12$ 9:28 & 49.9 & 8.51 & 14.65 & 6.14 \\
\hline Test-5-Na-MM-2 & 8 & 0.2215 & 25.5566 & 3/16/12 9:28 & 49.4 & 3/19/12 9:28 & 49.8 & 8.49 & 14.07 & 5.58 \\
\hline Test-5-Na-MM-3 & 9 & 0.2202 & 25.8741 & 3/16/12 9:30 & 49.8 & 3/19/12 9:30 & 49.9 & 8.45 & 14.24 & 5.79 \\
\hline Test-5-Na-MM-4 & 10 & 0.2187 & 26.1595 & 3/16/12 9:31 & 49.8 & 3/19/12 9:31 & 49.8 & 8.55 & 14.26 & 5.71 \\
\hline Test-5-Na-MM-5 & 11 & 0.2241 & 28.7331 & 3/16/12 9:32 & 49.3 & 3/19/12 9:32 & 49.5 & 8.45 & 14.54 & 6.09 \\
\hline Test-5-Na-MM-6 & 12 & 0.2224 & 31.2936 & 3/16/12 9:34 & 49.4 & 3/19/12 9:34 & 50.0 & 8.42 & 15.33 & 6.91 \\
\hline Test-5-Na-NN-1 & 13 & 0.2225 & 26.0848 & 3/16/12 9:35 & 49.8 & 3/19/12 9:35 & 49.3 & 8.35 & 14.27 & 5.92 \\
\hline Test-5-Na-NN-2 & 14 & 0.2278 & 28.5587 & 3/16/12 9:37 & 50.0 & 3/19/12 9:37 & 49.7 & 8.42 & 15.21 & 6.79 \\
\hline Test-5-Na-NN-3 & 15 & 0.2216 & 31.0837 & 3/16/12 9:38 & 50.0 & 3/19/12 9:38 & 49.5 & 8.36 & 15.17 & 6.81 \\
\hline Test-5-Na-OO-1 & 16 & 0.2205 & 25.8754 & 3/16/12 9:41 & 50.1 & 3/19/12 9:41 & 50.0 & 8.36 & 14.15 & 5.79 \\
\hline Test-5-Na-OO-2 & 17 & 0.2180 & 28.3813 & 3/16/12 9:42 & 50.0 & 3/19/12 9:42 & 49.9 & 8.57 & 14.75 & 6.18 \\
\hline Test-5-Na-OO-3 & 18 & 0.2208 & 30.8050 & 3/16/12 9:43 & 49.7 & 3/19/12 9:43 & 50.0 & 8.39 & 15.14 & 6.75 \\
\hline Test-5-Na-I-1 & 19 & 0.2202 & 24.7805 & 2/14/12 10:34 & 49.2 & 2/17/12 10:34 & 50.3 & 8.54 & 14.04 & 5.50 \\
\hline Test-5-Na-I-2 & 20 & 0.2219 & 25.5684 & 2/10/12 10:11 & 48.0 & 2/13/12 10:10 & 49.5 & 8.58 & 15.08 & 6.50 \\
\hline Test-5-Na-I-3 & 21 & 0.2209 & 25.9168 & 2/14/12 10:36 & 48.6 & 2/17/12 10:35 & 50.5 & 8.47 & 14.33 & 5.86 \\
\hline Test-5-Na-I-4 & 22 & 0.2202 & 26.1485 & 2/14/12 10:38 & 49.1 & 2/17/12 10:37 & 50.8 & 8.57 & 14.77 & 6.20 \\
\hline Test-5-Na-I-5 & 23 & 0.2160 & 28.6216 & 2/14/12 10:40 & 49.5 & 2/17/12 10:39 & 50.5 & 8.54 & 15.32 & 6.78 \\
\hline Test-5-Na-I-6 & 24 & 0.2211 & 31.1057 & 2/14/12 10:41 & 48.9 & 2/17/12 10:41 & 50.4 & 8.68 & 15.64 & 6.96 \\
\hline Test-5-Na-J-1 & 25 & 0.2213 & 25.0198 & 2/28/12 9:28 & 49.3 & $3 / 2 / 12$ 9:28 & 50.2 & 8.61 & 13.97 & 5.36 \\
\hline Test-5-Na-J-2 & 26 & 0.2172 & 25.6548 & 2/10/12 10:13 & 47.3 & 2/13/12 10:11 & 50.5 & 8.67 & 14.33 & 5.66 \\
\hline Test-5-Na-J-3 & 27 & 0.2185 & 25.8702 & 2/28/12 9:31 & 49.5 & $3 / 2 / 12$ 9:30 & 50.1 & 8.58 & 14.31 & 5.73 \\
\hline Test-5-Na-J-4 & 28 & 0.2216 & 26.3398 & 2/28/12 9:32 & 49.8 & 3/2/12 9:31 & 50.1 & 8.61 & 14.31 & 5.70 \\
\hline Test-5-Na-J-5 & 29 & 0.2190 & 28.7302 & 2/28/12 9:34 & 49.6 & 3/2/12 9:33 & 50.3 & 8.54 & 14.70 & 6.16 \\
\hline
\end{tabular}


Table A.45. (contd)

\begin{tabular}{|c|c|c|c|c|c|c|c|c|c|c|}
\hline Sample & $\begin{array}{c}\text { Simulant ID } \\
\text { Used }\end{array}$ & $\begin{array}{l}\text { Resin } \\
\text { Added }\end{array}$ & $\begin{array}{l}\text { Simulant } \\
\text { Added }\end{array}$ & Resin Added & $\begin{array}{l}\text { Temp When } \\
\text { Added }\end{array}$ & Resin Removed & $\begin{array}{l}\text { Temp When } \\
\text { Removed }\end{array}$ & \multicolumn{3}{|c|}{ Sample Vial Weight, g } \\
\hline Test-5-Na-J-6 & 30 & 0.2199 & 31.2610 & $2 / 28 / 129: 35$ & 49.2 & $3 / 2 / 129: 35$ & 49.8 & 8.68 & 15.40 & 6.72 \\
\hline Test-5-Na-K-2 & 32 & 0.2222 & 28.3903 & 2/28/12 9:40 & 49.2 & 3/2/12 9:38 & 50.7 & 8.65 & 14.86 & 6.21 \\
\hline Test-5-Na-K-3 & 33 & 0.2207 & 30.6740 & 2/10/12 10:14 & 48.4 & 2/13/12 10:13 & 51.2 & 8.63 & 13.71 & 5.08 \\
\hline Test-5-Na-L-1 & 34 & 0.2175 & 25.8899 & 2/28/12 9:41 & 48.9 & 3/2/12 9:41 & 50.4 & 8.58 & 14.25 & 5.67 \\
\hline Test-5-Na-Q-1 & 37 & 0.2225 & 24.8396 & 2/28/12 9:45 & 48.8 & 3/2/12 9:45 & 48.4 & 8.56 & 14.71 & 6.15 \\
\hline Test-5-Na-Q-2 & 38 & 0.2198 & 25.3875 & 2/10/12 10:15 & 50.1 & 2/13/12 10:14 & 51.0 & 8.57 & 13.83 & 5.26 \\
\hline Test-5-Na-Q-3 & 39 & 0.2186 & 25.7891 & 2/28/12 9:46 & 49.0 & $3 / 2 / 129: 46$ & 50.2 & 8.57 & 13.91 & 5.34 \\
\hline Test-5-Na-Q-4 & 40 & 0.2195 & 26.0198 & 2/28/12 9:48 & 49.7 & 3/2/12 9:48 & 50.8 & 8.67 & 14.63 & 5.96 \\
\hline Test-5-Na-Q-5 & 41 & 0.2224 & 28.6569 & 2/28/12 9:49 & 49.6 & 3/2/12 9:49 & 50.2 & 8.51 & 14.93 & 6.42 \\
\hline Test-5-Na-Q-6 & 42 & 0.2221 & 31.1025 & 2/28/12 9:51 & 49.9 & 3/2/12 9:51 & 50.3 & 8.56 & 15.38 & 6.82 \\
\hline Test-5-Na-R-5 & 47 & 0.2206 & 28.7751 & 2/28/12 9:58 & 48.9 & 3/2/12 9:58 & 50.2 & 8.58 & 15.01 & 6.43 \\
\hline Test-5-Na-R-6 & 48 & 0.2184 & 31.2205 & 2/28/12 10:00 & 49.2 & 3/2/12 9:59 & 49.9 & 8.55 & 16.50 & 7.95 \\
\hline Test-5-Na-S-1 & 49 & 0.2196 & 25.9241 & 3/2/12 12:57 & 49.6 & 3/5/12 12:56 & 49.9 & 8.61 & 13.75 & 5.14 \\
\hline Test-5-Na-S-2 & 50 & 0.2207 & 28.5037 & 3/2/12 12:58 & 49.3 & 3/5/12 12:57 & 49.9 & 8.57 & 14.69 & 6.12 \\
\hline Test-5-Na-S-3 & 51 & 0.2208 & 30.7745 & $2 / 10 / 12$ 10:21 & 50.1 & 2/13/12 10:19 & 50.9 & 8.54 & 15.69 & 7.15 \\
\hline Test-5-Na-T-1 & 52 & 0.2227 & 25.8485 & $3 / 2 / 1213: 00$ & 49.3 & $3 / 5 / 1212: 59$ & 49.9 & 8.56 & 14.19 & 5.63 \\
\hline Test-5-Na-T-2 & 53 & 0.2241 & 28.5346 & 2/10/12 10:22 & 50.1 & 2/13/12 10:20 & 50.9 & 8.55 & 14.92 & 6.37 \\
\hline Test-5-Na-T-3 & 54 & 0.2224 & 30.9574 & $2 / 10 / 12 \quad 10: 24$ & 50.1 & $2 / 13 / 1210: 22$ & 50.8 & 8.57 & 14.68 & 6.11 \\
\hline Test-5-Na-Y-1 & 55 & 0.2231 & 25.0438 & 3/2/12 13:01 & 49.1 & 3/5/12 13:00 & 49.9 & 8.63 & 14.15 & 5.52 \\
\hline Test-5-Na-Y-2 & 56 & 0.2219 & 25.4408 & 2/10/12 10:25 & 50.1 & 2/13/12 10:24 & 50.4 & 8.63 & 14.28 & 5.65 \\
\hline Test-5-Na-Y-3 & 57 & 0.2214 & 25.8376 & 3/2/12 13:02 & 49.1 & $3 / 5 / 12$ 13:02 & 50.0 & 8.48 & 13.90 & 5.42 \\
\hline
\end{tabular}


Table A.45. (contd)

\begin{tabular}{|c|c|c|c|c|c|c|c|c|c|c|}
\hline Sample & $\begin{array}{c}\text { Simulant ID } \\
\text { Used }\end{array}$ & $\begin{array}{c}\text { Resin } \\
\text { Added }\end{array}$ & $\begin{array}{c}\text { Simulant } \\
\text { Added }\end{array}$ & Resin Added & $\begin{array}{c}\text { Temp When } \\
\text { Added }\end{array}$ & Resin Removed & $\begin{array}{c}\text { Temp When } \\
\text { Removed }\end{array}$ & \multicolumn{3}{|c|}{ Sample Vial Weight, g } \\
\hline ID No. & & (g) & (g) & Date/Time & $\left({ }^{\circ} \mathrm{C}\right)$ & Date/Time & $\left({ }^{\circ} \mathrm{C}\right)$ & Tare & Gross & Net \\
\hline Test-5-Na-Y-5 & 59 & 0.2214 & 28.7729 & $3 / 2 / 1213: 07$ & 49.2 & $3 / 5 / 1213: 06$ & 50.3 & 8.52 & 14.81 & 6.29 \\
\hline Test-5-Na-Y-6 & 60 & 0.2232 & 31.2851 & 3/2/12 13:08 & 48.9 & 3/5/12 13:07 & 50.2 & 8.52 & 15.58 & 7.06 \\
\hline Test-5-Na-Z-1 & 61 & 0.2243 & 24.9957 & 3/2/12 13:11 & 48.8 & 3/5/12 13:11 & 50.2 & 8.52 & 13.95 & 5.43 \\
\hline Test-5-Na-Z-2 & 62 & 0.2191 & 25.4883 & 2/10/12 10:27 & 50.4 & 2/13/12 10:26 & 50.8 & 8.53 & 14.14 & 5.61 \\
\hline Test-5-Na-Z-3 & 63 & 0.2227 & 25.8878 & 3/2/12 13:13 & 49.8 & 3/5/12 13:12 & 50.3 & 8.58 & 14.29 & 5.71 \\
\hline Test-5-Na-Z-4 & 64 & 0.2216 & 26.2032 & 3/2/12 13:15 & 49.2 & 3/5/12 13:14 & 50.3 & 8.52 & 14.32 & 5.80 \\
\hline Test-5-Na-Z-5 & 65 & 0.2226 & 28.8929 & 3/2/12 13:16 & 49.2 & 3/5/12 13:15 & 50.2 & 8.57 & 14.59 & 6.02 \\
\hline Test-5-Na-Z-6 & 66 & 0.2216 & 31.2591 & 3/2/12 13:18 & 50.0 & 3/5/12 13:17 & 50.6 & 8.45 & 15.44 & 6.99 \\
\hline Test-5-Na-AA-1 & 67 & 0.2212 & 25.9060 & 3/2/12 13:20 & 50.2 & 3/5/12 13:19 & 50.2 & 8.43 & 14.15 & 5.72 \\
\hline Test-5-Na-AA-2 & 68 & 0.2189 & 28.3724 & $3 / 2 / 1213: 21$ & 50.1 & $3 / 5 / 12$ 13:21 & 50.3 & 8.44 & 14.77 & 6.33 \\
\hline Test-5-Na-AA-3 & 69 & 0.2202 & 30.8017 & 2/10/12 10:29 & 50.3 & 2/13/12 10:28 & 50.9 & 8.53 & 15.33 & 6.80 \\
\hline Test-5-Na-BB-1 & 70 & 0.2217 & 26.0996 & 3/2/12 13:22 & 49.5 & 3/5/12 13:22 & 50.2 & 8.59 & 14.54 & 5.95 \\
\hline Test-5-Na-BB-2 & 71 & 0.2225 & 28.2844 & 2/10/12 10:30 & 50.2 & 2/13/12 10:29 & 50.8 & 8.62 & 14.62 & 6.00 \\
\hline Test-5-Na-BB-3 & 72 & 0.2218 & 31.0622 & 2/10/12 10:32 & 50.0 & 2/13/12 10:30 & 50.6 & 8.45 & 14.79 & 6.34 \\
\hline
\end{tabular}

Table A.46. Datasheet for $25^{\circ} \mathrm{C}$ Batch Loading Tests

\begin{tabular}{|c|c|c|c|c|c|c|c|c|c|c|}
\hline Sample & $\begin{array}{c}\text { Simulant ID } \\
\text { Used }\end{array}$ & $\begin{array}{l}\text { Resin } \\
\text { Added }\end{array}$ & $\begin{array}{l}\text { Simulant } \\
\text { Added }\end{array}$ & Resin Added & $\begin{array}{l}\text { Temp When } \\
\text { Added }\end{array}$ & Resin Removed & $\begin{array}{c}\text { Temp When } \\
\text { Removed }\end{array}$ & \multicolumn{3}{|c|}{ Sample Vial Weight, g } \\
\hline ID No. & & (g) & (g) & Date/Time & $\left({ }^{\circ} \mathrm{C}\right)$ & Date/Time & $\left({ }^{\circ} \mathrm{C}\right)$ & Tare & Gross & Net \\
\hline Test-5-Na-QQ-1 & 1 & 0.2193 & 24.7812 & 3/16/12 9:46 & 23.6 & 3/19/12 9:46 & 25.1 & NA & 13.85 & NA \\
\hline Test-5-Na-QQ-2 & 2 & 0.2185 & 25.5703 & 3/16/12 9:48 & 23.2 & 3/19/12 9:48 & 25.1 & 8.57 & 14.21 & 5.64 \\
\hline Test-5-Na-QQ-3 & 3 & 0.2226 & 25.7690 & 3/16/12 9:50 & 23.0 & 3/19/12 9:50 & 25.1 & 8.52 & 14.39 & 5.87 \\
\hline Test-5-Na-QQ-4 & 4 & 0.2224 & 26.0461 & 3/16/12 9:52 & 23.2 & 3/19/12 9:52 & 25.1 & 8.52 & 14.25 & 5.73 \\
\hline Test-5-Na-QQ-5 & 5 & 0.2238 & 28.7336 & 3/16/12 9:54 & 23.1 & 3/19/12 9:54 & 25.1 & 8.51 & 15.06 & 6.55 \\
\hline Test-5-Na-QQ-6 & 6 & 0.2209 & 31.3590 & 3/16/12 9:56 & 23.0 & 3/19/12 9:56 & 25.0 & 8.43 & 15.53 & 7.10 \\
\hline Test-5-Na-RR-1 & 7 & 0.2208 & 24.9527 & 3/16/12 9:57 & 23.1 & 3/19/12 9:58 & 25.0 & 8.45 & 13.83 & 5.38 \\
\hline Test-5-Na-RR-2 & 8 & 0.2206 & 25.3683 & 3/16/12 9:59 & 23.3 & 3/19/12 9:59 & 25.0 & 8.40 & 14.11 & 5.71 \\
\hline Test-5-Na-RR-3 & 9 & 0.2201 & 25.8808 & 3/16/12 10:01 & 23.2 & 3/19/12 10:01 & 25.0 & 8.44 & 14.31 & 5.87 \\
\hline
\end{tabular}


Table A.46. (contd)

\begin{tabular}{|c|c|c|c|c|c|c|c|c|c|c|}
\hline Sample & $\begin{array}{c}\text { Simulant ID } \\
\text { Used }\end{array}$ & $\begin{array}{l}\text { Resin } \\
\text { Added }\end{array}$ & $\begin{array}{l}\text { Simulant } \\
\text { Added }\end{array}$ & Resin Added & $\begin{array}{c}\text { Temp When } \\
\text { Added }\end{array}$ & Resin Removed & $\begin{array}{c}\text { Temp When } \\
\text { Removed }\end{array}$ & \multicolumn{3}{|c|}{ Sample Vial Weight, g } \\
\hline ID No. & & (g) & (g) & Date/Time & $\left({ }^{\circ} \mathrm{C}\right)$ & Date/Time & $\left({ }^{\circ} \mathrm{C}\right)$ & Tare & Gross & Net \\
\hline Test-5-Na-RR-4 & 10 & 0.2197 & 26.3019 & $3 / 16 / 12$ 10:04 & 23.3 & $3 / 19 / 12$ 10:04 & 25.0 & 8.45 & 13.93 & 5.48 \\
\hline Test-5-Na-RR-5 & 11 & 0.2205 & 28.8853 & 3/16/12 10:06 & 23.3 & 3/19/12 10:06 & 25.0 & 8.53 & 15.02 & 6.49 \\
\hline Test-5-Na-RR-6 & 12 & 0.2212 & 31.3175 & 3/16/12 10:07 & 23.2 & 3/19/12 10:07 & 25.0 & 8.51 & 15.53 & 7.02 \\
\hline Test-5-Na-SS-1 & 13 & 0.2176 & 25.9331 & 3/16/12 10:09 & 23.3 & 3/19/12 10:09 & 25.0 & 8.46 & 14.16 & 5.70 \\
\hline Test-5-Na-SS-2 & 14 & 0.2206 & 28.5491 & 3/16/12 10:10 & 23.2 & 3/19/12 10:10 & 25.0 & 8.58 & 15.09 & 6.51 \\
\hline Test-5-Na-SS-3 & 15 & 0.2194 & 30.8957 & 3/16/12 10:12 & 23.0 & 3/19/12 10:12 & 25.0 & 8.45 & 15.56 & 7.11 \\
\hline Test-5-Na-TT-1 & 16 & 0.2215 & 25.9330 & 3/16/12 10:13 & 23.0 & $3 / 19 / 12$ 10:13 & 25.0 & 8.41 & 14.11 & 5.70 \\
\hline Test-5-Na-TT-2 & 17 & 0.2196 & 28.4645 & 3/16/12 10:15 & 23.1 & 3/19/12 10:15 & 25.0 & 8.51 & 14.81 & 6.30 \\
\hline Test-5-Na-TT-3 & 18 & 0.2228 & 30.8095 & 3/16/12 10:17 & 23.4 & 3/19/12 10:17 & 25.0 & 8.52 & 15.14 & 6.62 \\
\hline Test-5-Na-M-1 & 19 & 0.2220 & 24.7771 & 2/14/12 11:11 & 23.3 & 2/17/12 11:11 & 25.0 & 8.53 & 14.07 & 5.54 \\
\hline Test-5-Na-M-2 & 20 & 0.2197 & 25.5016 & 2/10/12 10:42 & 23.3 & 2/13/12 10:37 & 25.2 & 8.67 & 14.38 & 5.71 \\
\hline Test-5-Na-M-3 & 21 & 0.2176 & 25.9030 & 2/14/12 11:14 & 23.5 & 2/17/12 11:13 & 25.0 & 8.43 & 14.24 & 5.81 \\
\hline Test-5-Na-M-4 & 22 & 0.2186 & 26.2121 & 2/14/12 11:16 & 23.6 & 2/17/12 11:15 & 25.0 & 8.57 & 14.43 & 5.86 \\
\hline Test-5-Na-M-5 & 23 & 0.2202 & 28.7022 & 2/14/12 11:18 & 23.4 & 2/17/12 11:16 & 25.0 & 8.43 & 15.02 & 6.59 \\
\hline Test-5-Na-M-6 & 24 & 0.2213 & 31.1901 & 2/14/12 11:20 & 23.1 & 2/17/12 11:17 & 25.0 & 8.51 & 15.67 & 7.16 \\
\hline Test-5-Na-N-1 & 25 & 0.2199 & 25.0256 & 2/24/12 13:40 & 25.0 & 2/27/12 13:40 & 25.1 & 8.52 & 13.58 & 5.06 \\
\hline Test-5-Na-N-2 & 26 & 0.2209 & 25.4414 & 2/10/12 10:45 & 23.2 & 2/13/12 10:38 & 25.2 & 8.63 & 14.26 & 5.63 \\
\hline Test-5-Na-N-3 & 27 & 0.2198 & 25.9245 & 2/24/12 13:41 & 23.4 & 2/27/12 13:41 & 25.0 & 8.44 & 15.08 & 6.64 \\
\hline Test-5-Na-N-4 & 28 & 0.2180 & 26.0331 & 2/24/12 13:44 & 23.4 & 2/27/12 13:43 & 25.0 & 8.47 & 15.17 & 6.70 \\
\hline Test-5-Na-N-5 & 29 & 0.2186 & 28.7700 & 2/24/12 13:45 & 23.4 & 2/27/12 13:44 & 25.0 & 8.52 & 15.34 & 6.82 \\
\hline Test-5-Na-N-6 & 30 & 0.2200 & 31.1883 & 2/24/12 13:47 & 23.5 & 2/27/12 13:46 & 25.0 & 8.40 & 16.34 & 7.94 \\
\hline Test-5-Na-O-1 & 31 & 0.2206 & 26.0259 & 2/24/12 13:49 & 23.5 & 2/27/12 13:49 & 25.0 & 8.44 & 14.48 & 6.04 \\
\hline Test-5-Na-O-2 & 32 & 0.2200 & 28.2928 & 2/24/12 13:52 & 23.4 & 2/27/12 13:52 & 25.0 & 8.47 & 15.37 & 6.90 \\
\hline Test-5-Na-O-3 & 33 & 0.2235 & 30.7049 & 2/10/12 10:46 & 23.0 & 2/13/12 10:39 & 25.2 & 8.56 & 15.69 & 7.13 \\
\hline Test-5-Na-P-1 & 34 & 0.2182 & 25.9357 & 2/24/12 13:54 & 23.4 & 2/27/12 13:53 & 25.0 & 8.54 & 14.62 & 6.08 \\
\hline Test-5-Na-P-2 & 35 & 0.2208 & 28.4036 & 2/24/12 13:57 & 23.6 & 2/27/12 13:57 & 25.0 & 8.39 & 15.06 & 6.67 \\
\hline Test-5-Na-P-3 & 36 & 0.2214 & 30.7870 & 2/10/12 10:48 & 23.1 & 2/13/12 10:40 & 25.2 & 8.61 & 15.55 & 6.94 \\
\hline Test-5-Na-U-1 & 37 & 0.2180 & 25.0587 & 2/24/12 13:59 & 23.6 & 2/27/12 13:58 & 25.0 & 8.53 & 13.86 & 5.33 \\
\hline Test-5-Na-U-2 & 38 & 0.2202 & 25.6184 & 2/10/12 10:50 & 23.2 & 2/13/12 10:41 & 25.2 & 8.54 & 13.28 & 4.74 \\
\hline
\end{tabular}


Table A.46. (contd)

\begin{tabular}{|c|c|c|c|c|c|c|c|c|c|c|}
\hline Sample & $\begin{array}{l}\text { Simulant ID } \\
\text { Used }\end{array}$ & $\begin{array}{l}\text { Resin } \\
\text { Added }\end{array}$ & $\begin{array}{l}\text { Simulant } \\
\text { Added }\end{array}$ & Resin Added & $\begin{array}{l}\text { Temp When } \\
\text { Added }\end{array}$ & Resin Removed & $\begin{array}{l}\text { Temp When } \\
\text { Removed }\end{array}$ & \multicolumn{3}{|c|}{ Sample Vial Weight, g } \\
\hline Test-5-Na-U-3 & 39 & 0.2215 & 25.6966 & $2 / 24 / 1214: 02$ & 23.3 & $2 / 27 / 1214: 02$ & 25.0 & 8.46 & 14.24 & 5.78 \\
\hline Test-5-Na-U-5 & 41 & 0.2201 & 28.7124 & 2/24/12 14:05 & 23.5 & 2/27/12 14:05 & 25.0 & 8.49 & 14.64 & 6.15 \\
\hline Test-5-Na-U-6 & 42 & 0.2215 & 31.0854 & 2/24/12 14:09 & 23.3 & 2/27/12 14:08 & 25.0 & 8.52 & 15.30 & 6.78 \\
\hline Test-5-Na-V-1 & 43 & 0.2230 & 24.8652 & 2/24/12 14:11 & 23.4 & 2/27/12 14:10 & 25.0 & 8.41 & 13.62 & 5.21 \\
\hline Test-5-Na-V-4 & 46 & 0.2201 & 26.2559 & 2/24/12 14:15 & 23.3 & 2/27/12 14:16 & 25.0 & 8.43 & 14.21 & 5.78 \\
\hline Test-5-Na-V-5 & 47 & 0.2201 & 28.6834 & 2/24/12 14:18 & 23.2 & 2/27/12 14:17 & 25.0 & 8.43 & 15.05 & 6.62 \\
\hline Test-5-Na-V-6 & 48 & 0.2217 & 31.1638 & 2/24/12 14:19 & 23.3 & 2/27/12 14:18 & 25.0 & 8.55 & 16.44 & 7.89 \\
\hline Test-5-Na-W-1 & 49 & 0.2191 & 25.8934 & 3/2/12 13:25 & 23.1 & 3/5/12 13:24 & 24.9 & 8.45 & 14.16 & 5.71 \\
\hline Test-5-Na-W-2 & 50 & 0.2200 & 28.4822 & 3/2/12 13:27 & 23.1 & 3/5/12 13:26 & 24.9 & 8.47 & 14.85 & 6.38 \\
\hline Test-5-Na-W-3 & 51 & 0.2233 & 30.7264 & $2 / 10 / 12$ 10:54 & 23.0 & 2/13/12 10:43 & 25.2 & 8.46 & 14.70 & 6.24 \\
\hline Test-5-Na-CC-2 & 56 & 0.2218 & 25.4572 & $2 / 10 / 12$ 10:59 & 23.5 & 2/13/12 10:45 & 25.2 & 8.57 & 14.60 & 6.03 \\
\hline Test-5-Na-CC-3 & 57 & 0.2196 & 25.8235 & 3/2/12 13:31 & 23.1 & 3/5/12 13:31 & 25.0 & 8.49 & 14.05 & 5.56 \\
\hline Test-5-Na-CC-4 & 58 & 0.2207 & 26.2880 & 3/2/12 13:33 & 23.0 & 3/5/12 13:32 & 25.0 & 8.53 & 14.02 & 5.49 \\
\hline Test-5-Na-CC-5 & 59 & 0.2191 & 28.8083 & 3/2/12 13:36 & 23.0 & 3/5/12 13:36 & 25.0 & 8.40 & 15.05 & 6.65 \\
\hline Test-5-Na-CC-6 & 60 & 0.2204 & 31.3754 & 3/2/12 13:39 & 23.0 & 3/5/12 13:38 & 25.0 & 8.46 & 15.48 & 7.02 \\
\hline Test-5-Na-DD-1 & 61 & 0.2215 & 25.0416 & 3/2/12 13:40 & 22.9 & 3/5/12 13:40 & 25.0 & 8.45 & 13.68 & 5.23 \\
\hline Test-5-Na-DD-2 & 62 & 0.2237 & 25.4940 & 2/10/12 11:02 & 23.2 & 2/13/12 10:46 & 25.2 & 8.59 & 14.01 & 5.42 \\
\hline Test-5-Na-DD-3 & 63 & 0.2181 & 25.9740 & 3/2/12 13:41 & 23.0 & 3/5/12 13:41 & 25.0 & 8.47 & 14.20 & 5.73 \\
\hline Test-5-Na-DD-4 & 64 & 0.2220 & 26.1801 & 3/2/12 13:43 & 22.9 & 3/5/12 13:42 & 25.0 & 8.44 & 14.00 & 5.56 \\
\hline Test-5-Na-DD-5 & 65 & 0.2190 & 28.7919 & 3/2/12 13:45 & 22.8 & 3/5/12 13:45 & 25.0 & 8.49 & 15.22 & 6.73 \\
\hline Test-5-Na-DD-6 & 66 & 0.2229 & 31.3991 & 3/2/12 13:46 & 22.8 & 3/5/12 13:46 & 25.1 & 8.36 & 15.31 & 6.95 \\
\hline
\end{tabular}


Table A.46. (contd)

\begin{tabular}{cccccccccc}
\hline Sample & $\begin{array}{c}\text { Simulant ID } \\
\text { Used }\end{array}$ & $\begin{array}{c}\text { Resin } \\
\text { Added }\end{array}$ & $\begin{array}{c}\text { Simulant } \\
\text { Added }\end{array}$ & Resin Added & $\begin{array}{c}\text { Temp When } \\
\text { Added }\end{array}$ & \multicolumn{2}{c}{$\begin{array}{c}\text { Temp When } \\
\text { Removed }\end{array}$} & \multicolumn{2}{c}{ Semoved } \\
Sample Vial Weight, g
\end{tabular}

Table A.47. Datasheet for $35^{\circ} \mathrm{C}$ Batch Loading Tests

\begin{tabular}{|c|c|c|c|c|c|c|c|c|c|c|}
\hline Sample & $\begin{array}{c}\text { Simulant ID } \\
\text { Used }\end{array}$ & $\begin{array}{l}\text { Resin } \\
\text { Added }\end{array}$ & $\begin{array}{l}\text { Simulant } \\
\text { Added }\end{array}$ & Resin Added & $\begin{array}{c}\text { Temp When } \\
\text { Added }\end{array}$ & Resin Removed & $\begin{array}{c}\text { Temp When } \\
\text { Removed }\end{array}$ & \multicolumn{3}{|c|}{ Sample Vial Weight, g } \\
\hline ID No. & & (g) & (g) & Date/Time & $\left({ }^{\circ} \mathrm{C}\right)$ & Date/Time & $\left({ }^{\circ} \mathrm{C}\right)$ & Tare & Gross & Net \\
\hline Test-5-Na-GG-1 & 72 & 0.2214 & 30.6308 & 2/3/12 10:41 & 35.0 & 2/6/12 10:41 & 34.8 & 8.54 & 14.81 & 6.27 \\
\hline Test-5-Na-GG-2 & 54 & 0.2253 & 30.7515 & 2/3/12 10:43 & 34.8 & 2/6/12 10:43 & 35.2 & 8.48 & 16.36 & 7.88 \\
\hline Test-5-Na-GG-3 & 36 & 0.2170 & 30.7809 & 2/3/12 10:44 & 34.9 & 2/6/12 10:44 & 35.0 & 8.64 & 16.83 & 8.19 \\
\hline Test-5-Na-PP-1 & 18 & 0.2222 & 30.8588 & 3/12/12 9:35 & 34.7 & 3/15/12 9:38 & 34.9 & 8.56 & 14.82 & 6.26 \\
\hline Test-5-Na-HH-1 & 69 & 0.2199 & 30.6352 & 2/3/12 10:47 & 35.2 & 2/6/12 10:46 & 34.9 & 8.48 & 16.92 & 8.44 \\
\hline Test-5-Na-HH-2 & 51 & 0.2167 & 30.7031 & 2/3/12 10:52 & 35.1 & 2/6/12 10:47 & 35.7 & 8.46 & 16.74 & 8.28 \\
\hline Test-5-Na-HH-3 & 33 & 0.2208 & 30.7555 & 2/3/12 10:53 & 35.5 & 2/6/12 10:48 & 35.5 & 8.56 & 16.78 & 8.22 \\
\hline Test-5-Na-PP-2 & 15 & 0.2196 & 30.7681 & 3/12/12 9:36 & 34.7 & 3/15/12 9:39 & 34.8 & 8.47 & 15.28 & 6.81 \\
\hline Test-5-Na-II-1 & 62 & 0.2262 & 25.5009 & 2/3/12 10:55 & 35.0 & 2/6/12 10:50 & 35.3 & 8.53 & 15.41 & 6.88 \\
\hline Test-5-Na-II-2 & 44 & 0.2194 & 25.6125 & 2/3/12 10:57 & 35.0 & 2/6/12 10:51 & 35.2 & 8.56 & 15.98 & 7.42 \\
\hline Test-5-Na-II-3 & 26 & 0.2193 & 25.5171 & 2/3/12 10:58 & 35.3 & 2/6/12 10:53 & 35.7 & 8.60 & 15.56 & 6.96 \\
\hline Test-5-Na-PP-3 & 8 & 0.2192 & 25.6220 & 3/12/12 9:38 & 34.8 & 3/15/12 9:40 & 34.8 & 8.45 & 14.20 & 5.75 \\
\hline Test-5-Na-JJ-1 & 56 & 0.2208 & 25.3575 & 2/3/12 11:01 & 35.4 & 2/6/12 10:55 & 35.6 & 8.61 & 15.02 & 6.41 \\
\hline Test-5-Na-JJ-2 & 38 & 0.2221 & 25.3418 & 2/3/12 11:03 & 34.6 & 2/6/12 10:56 & 35.2 & 8.60 & 16.12 & 7.52 \\
\hline Test-5-Na-JJ-3 & 20 & 0.2227 & 25.3067 & 2/3/12 11:06 & 35.3 & 2/6/12 10:58 & 34.9 & 8.54 & 15.28 & 6.74 \\
\hline Test-5-Na-PP-4 & 2 & 0.2192 & 25.5606 & 3/12/12 9:39 & 34.7 & 3/15/12 9:41 & 34.9 & 8.39 & 13.78 & 5.39 \\
\hline Test-5-Na-KK-1 & 53 & 0.2243 & 28.4964 & 2/3/12 11:10 & 35.4 & 2/6/12 11:00 & 35.3 & 8.51 & 16.65 & 8.14 \\
\hline Test-5-Na-KK-2 & 71 & 0.2284 & 28.3653 & 2/3/12 11:12 & 35.2 & 2/6/12 11:01 & 35.4 & 8.95 & 16.53 & 7.58 \\
\hline
\end{tabular}


Appendix B

Analytical Data 



\section{Appendix B}

\section{Analytical Data}

Table B.1. Column A1 Test Analytical Data $\left(\mathrm{T}=45^{\circ} \mathrm{C}\right.$, Flow rate $\left.=10.62 \mathrm{~mL} / \mathrm{min}\right)$

\begin{tabular}{|c|c|c|c|c|c|c|c|c|c|c|c|c|c|c|c|}
\hline Sample ID & $\begin{array}{l}\text { Loading Time } \\
\text { (min) }\end{array}$ & $\begin{array}{c}\mathrm{Cs} \\
(\mathrm{mg} / \mathrm{kg})\end{array}$ & $\begin{array}{c}\mathrm{Al} \\
(\mathrm{mg} / \mathrm{kg})\end{array}$ & $\begin{array}{c}\mathrm{Na} \\
(\mathrm{mg} / \mathrm{kg})\end{array}$ & $\begin{array}{c}\mathrm{K} \\
(\mathrm{mg} / \mathrm{kg})\end{array}$ & $\begin{array}{l}\text { OH-Free } \\
\text { (meq/mL) }\end{array}$ & $\begin{array}{l}\text { OH-Total } \\
\text { (meq/mL) }\end{array}$ & $\begin{array}{c}\mathrm{Cl} \\
(\mathrm{mg} / \mathrm{kg})\end{array}$ & $\begin{array}{c}\mathrm{NO}_{3} \\
(\mathrm{mg} / \mathrm{kg})\end{array}$ & $\begin{array}{c}\mathrm{NO}_{2} \\
(\mathrm{mg} / \mathrm{kg})\end{array}$ & $\begin{array}{c}\mathrm{PO}_{4} \\
(\mathrm{mg} / \mathrm{kg})\end{array}$ & $\begin{array}{c}\mathrm{SO}_{4} \\
(\mathrm{mg} / \mathrm{kg})\end{array}$ & $\begin{array}{c}\mathrm{C}_{2} \mathrm{O}_{4} \\
(\mathrm{mg} / \mathrm{kg})\end{array}$ & $\begin{array}{c}\text { TIC } \\
(\mathrm{mg} / \mathrm{kg})\end{array}$ & $\begin{array}{c}\text { TOC } \\
(\mathrm{mg} / \mathrm{kg})\end{array}$ \\
\hline A1-LD-00 & 0 & 5.19 & 3490 & 93700 & 1030 & 1.52 & 2.21 & $<64.1$ & 23000 & 9290 & 308 & 873 & 1210 & 8065 & 417 \\
\hline A1-LD-06 & 6 & 4.87 & 3470 & 90500 & 1010 & 1.50 & 2.18 & $<64.8$ & 22700 & 9060 & 302 & 865 & 1190 & 8010 & 415 \\
\hline A1-LD-12 & 12 & 3.38 & 3370 & 87900 & 962 & 1.47 & 2.13 & $<64.7$ & 22500 & 8990 & 322 & 824 & 1120 & 7905 & 405 \\
\hline A1-LD-18 & 18 & 3.06 & 3470 & 89100 & 966 & 1.47 & 2.13 & $<65.4$ & 22700 & 9060 & 300 & 838 & 1150 & 7905 & 394 \\
\hline A1-LD-24 & 24 & 2.77 & 3270 & 89900 & 964 & 1.47 & 2.14 & $<64.8$ & 22200 & 8860 & 295 & 828 & 1130 & 8100 & 422 \\
\hline A1-LD-36 & 36 & 2.28 & 3410 & 87300 & 984 & 1.46 & 2.14 & $<64.7$ & 21400 & 8990 & 295 & 839 & 1150 & 8010 & 412 \\
\hline A1-LD-48 & 48 & 1.95 & 3470 & 88900 & 974 & 1.47 & 2.16 & $<64.7$ & 22700 & 9030 & 282 & 819 & 1110 & 7990 & 421 \\
\hline A1-LD-60 & 60 & 1.66 & 3270 & 87600 & 965 & 1.48 & 2.15 & $<65.0$ & 22700 & 9090 & 291 & 831 & 1140 & 8220 & 414 \\
\hline A1-LD-80 & 80 & 1.41 & 3400 & 90100 & 959 & 1.46 & 2.12 & $<65.0$ & 22300 & 8910 & 283 & 822 & 1110 & 7890 & 419 \\
\hline A1-LD-120 & 120 & 1.13 & 3360 & 88900 & 981 & 1.47 & 2.13 & $<64.9$ & 22200 & 8870 & 293 & 826 & 1130 & 8065 & 424 \\
\hline A1-LD-180 & 180 & 0.899 & 3370 & 90400 & 983 & 1.47 & 2.14 & $<64.9$ & 22200 & 8890 & 293 & 835 & 1140 & 7795 & 409 \\
\hline A1-LD-240 & 240 & 0.795 & 3380 & 87900 & 959 & 1.46 & 2.13 & $<64.6$ & 22200 & 8890 & 296 & 832 & 1140 & 7795 & 411 \\
\hline A1-LD-600 & 600 & 0.676 & 3410 & 89100 & 960 & 1.47 & 2.13 & $<65.0$ & 22500 & 9020 & 285 & 821 & 1110 & 7835 & 418 \\
\hline A1-FD-CP & $\begin{array}{c}\text { Feed } \\
\text { Displacement }\end{array}$ & 0.498 & 2200 & 60100 & 644 & 0.884 & 0.962 & $<72.6$ & 13900 & 6160 & 193 & 533 & 750 & 4735 & 264 \\
\hline A1-EL-CP & Elution & 14.5 & 4.41 & 1320 & 65.5 & $<0.05$ & $<0.05$ & $<82.0$ & 2450 & $<82.0$ & $<82.0$ & $<82.0$ & $<82.0$ & $<25.0$ & $<10.0$ \\
\hline Target & -- & 4.86 & 3280 & 93200 & 951 & 1.20 & 2.01 & 0 & 23100 & 9430 & 326 & 856 & 1210 & 7960 & 408 \\
\hline
\end{tabular}


Table B.2. Column A2 Test Analytical Data $\left(T=45^{\circ} \mathrm{C}\right.$, Flow rate $\left.=14.16 \mathrm{~mL} / \mathrm{min}\right)$

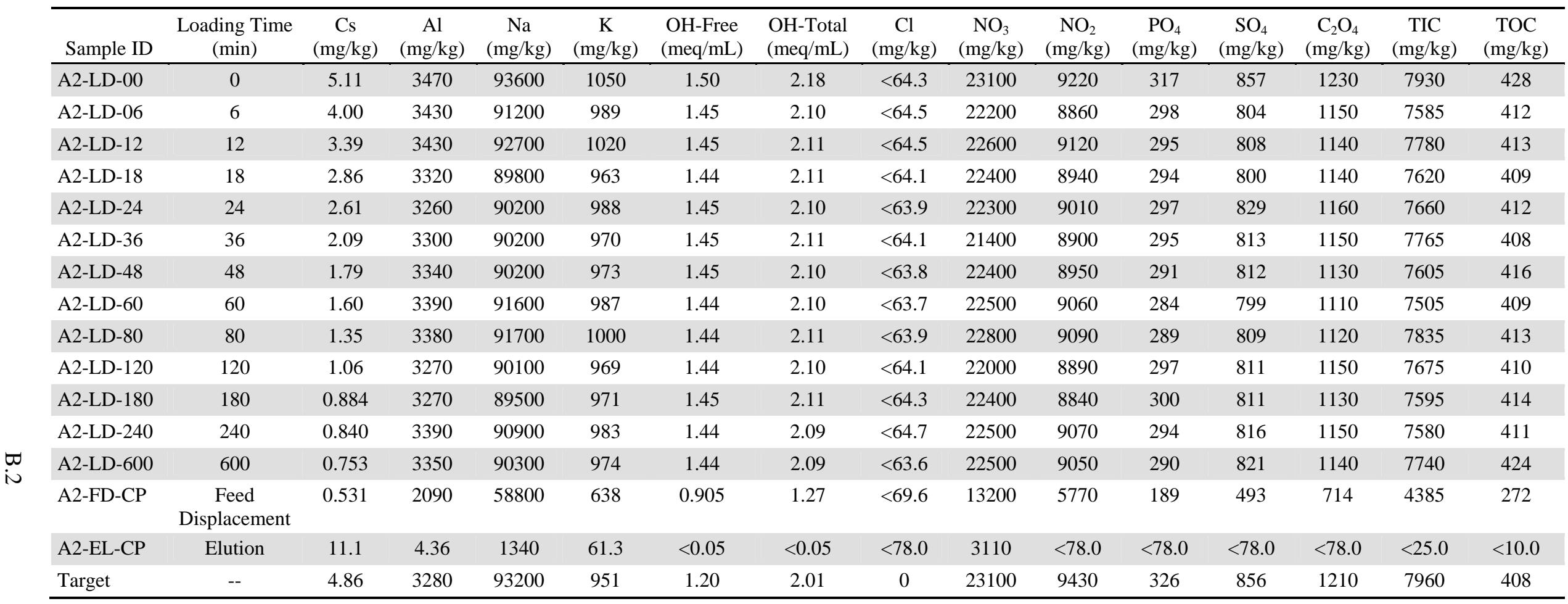


Table B.3. Column A3 Test Analytical Data $\left(\mathrm{T}=45^{\circ} \mathrm{C}\right.$, Flow rate $\left.=7.08 \mathrm{~mL} / \mathrm{min}\right)$

\begin{tabular}{|c|c|c|c|c|c|c|c|c|c|c|c|c|c|c|c|}
\hline Sample ID & $\begin{array}{l}\text { Loading Time } \\
\text { (min) }\end{array}$ & $\begin{array}{c}\mathrm{Cs} \\
(\mathrm{mg} / \mathrm{kg})\end{array}$ & $\begin{array}{c}\mathrm{Al} \\
(\mathrm{mg} / \mathrm{kg})\end{array}$ & $\begin{array}{c}\mathrm{Na} \\
(\mathrm{mg} / \mathrm{kg})\end{array}$ & $\begin{array}{c}\mathrm{K} \\
(\mathrm{mg} / \mathrm{kg})\end{array}$ & $\begin{array}{c}\text { OH-Free } \\
\text { (meq/mL) }\end{array}$ & $\begin{array}{l}\text { OH-Total } \\
(\mathrm{meq} / \mathrm{mL})\end{array}$ & $\begin{array}{c}\mathrm{Cl} \\
(\mathrm{mg} / \mathrm{kg})\end{array}$ & $\begin{array}{c}\mathrm{NO}_{3} \\
(\mathrm{mg} / \mathrm{kg})\end{array}$ & $\begin{array}{c}\mathrm{NO}_{2} \\
(\mathrm{mg} / \mathrm{kg})\end{array}$ & $\begin{array}{c}\mathrm{PO}_{4} \\
(\mathrm{mg} / \mathrm{kg})\end{array}$ & $\begin{array}{c}\mathrm{SO}_{4} \\
(\mathrm{mg} / \mathrm{kg})\end{array}$ & $\begin{array}{c}\mathrm{C}_{2} \mathrm{O}_{4} \\
(\mathrm{mg} / \mathrm{kg})\end{array}$ & $\begin{array}{c}\text { TIC } \\
\text { (mg/kg) }\end{array}$ & $\begin{array}{c}\text { TOC } \\
(\mathrm{mg} / \mathrm{kg})\end{array}$ \\
\hline A3-LD-00 & 0 & 5.27 & 3610 & 96100 & 1080 & 1.52 & 2.20 & $<32.1$ & 23200 & 9210 & 318 & 872 & 1250 & 8065 & 450 \\
\hline A3-LD-06 & 6 & 4.57 & 3550 & 94300 & 1040 & 1.47 & 2.13 & $<32.4$ & 22400 & 8830 & 307 & 852 & 1210 & 7715 & 423 \\
\hline A3-LD-12 & 12 & 3.89 & 3290 & 90900 & 1020 & 1.47 & 2.15 & $<32.3$ & 22600 & 8900 & 307 & 857 & 1250 & 8025 & 421 \\
\hline A3-LD-18 & 18 & 3.44 & 3370 & 91400 & 1020 & 1.44 & 2.11 & $<32.4$ & 22200 & 8800 & 301 & 843 & 1190 & 7625 & 412 \\
\hline A3-LD-24 & 24 & 3.11 & 3460 & 92300 & 1010 & 1.46 & 2.12 & $<32.4$ & 22900 & 9080 & 309 & 852 & 1210 & 7720 & 414 \\
\hline A3-LD-48 & 48 & 2.18 & 3290 & 91100 & 1010 & 1.46 & 2.13 & $<32.9$ & 22600 & 8970 & 293 & 839 & 1150 & 7955 & 426 \\
\hline A3-LD-60 & 60 & 1.92 & 3490 & 91700 & 997 & 1.45 & 2.11 & $<32.4$ & 22600 & 8950 & 300 & 855 & 1190 & 7930 & 421 \\
\hline A3-LD-80 & 80 & 1.60 & 3470 & 92400 & 997 & 1.45 & 2.12 & $<32.6$ & 22900 & 9070 & 299 & 872 & 1120 & 7960 & 421 \\
\hline A3-LD-120 & 120 & 1.24 & 3290 & 91100 & 1020 & 1.44 & 2.12 & $<32.4$ & 22200 & 8750 & 310 & 868 & 1150 & 7810 & 419 \\
\hline A3-LD-180 & 180 & 1.02 & 3570 & 92200 & 1020 & 1.46 & 2.12 & $<32.5$ & 22200 & 8790 & 303 & 849 & 1190 & 7755 & 418 \\
\hline A3-LD-240 & 240 & 0.942 & 3510 & 92800 & 1030 & 1.44 & 2.12 & $<32.3$ & 22300 & 8850 & 301 & 853 & 1180 & 8040 & 425 \\
\hline A3-FD-CP & $\begin{array}{c}\text { Feed } \\
\text { Displacement }\end{array}$ & 0.624 & 2100 & 58300 & 634 & 0.775 & 1.28 & $<36.1$ & 13100 & 5420 & 190 & 507 & 744 & 4250 & 285 \\
\hline A3-EL-CP & Elution & 20.4 & 2.99 & 1500 & 65.3 & $<0.05$ & $<0.05$ & $<39.8$ & 3110 & $<39.8$ & $<39.8$ & $<39.8$ & $<39.8$ & $<25.0$ & $<10.0$ \\
\hline Target & -- & 4.86 & 3280 & 93200 & 951 & 1.20 & 2.01 & 0 & 23100 & 9430 & 326 & 856 & 1210 & 7960 & 408 \\
\hline
\end{tabular}


Table B.4. Column A4 Test Analytical Data $\left(T=45^{\circ} \mathrm{C}\right.$, Flow rate $\left.=10.62 \mathrm{~mL} / \mathrm{min}\right)$

\begin{tabular}{|c|c|c|c|c|c|c|c|c|c|c|c|c|c|c|c|}
\hline Sample ID & $\begin{array}{l}\text { Loading Time } \\
\text { (min) }\end{array}$ & $\begin{array}{c}\mathrm{Cs} \\
(\mathrm{mg} / \mathrm{kg}) \\
\end{array}$ & $\begin{array}{c}\mathrm{Al} \\
(\mathrm{mg} / \mathrm{kg})\end{array}$ & $\begin{array}{c}\mathrm{Na} \\
(\mathrm{mg} / \mathrm{kg})\end{array}$ & $\begin{array}{c}\mathrm{K} \\
(\mathrm{mg} / \mathrm{kg})\end{array}$ & $\begin{array}{c}\text { OH-Free } \\
(\mathrm{meq} / \mathrm{mL})\end{array}$ & $\begin{array}{l}\text { OH-Total } \\
(\mathrm{meq} / \mathrm{mL})\end{array}$ & $\begin{array}{c}\mathrm{Cl} \\
(\mathrm{mg} / \mathrm{kg})\end{array}$ & $\begin{array}{c}\mathrm{NO}_{3} \\
(\mathrm{mg} / \mathrm{kg})\end{array}$ & $\begin{array}{c}\mathrm{NO}_{2} \\
(\mathrm{mg} / \mathrm{kg})\end{array}$ & $\begin{array}{c}\mathrm{PO}_{4} \\
(\mathrm{mg} / \mathrm{kg})\end{array}$ & $\begin{array}{c}\mathrm{SO}_{4} \\
(\mathrm{mg} / \mathrm{kg})\end{array}$ & $\begin{array}{c}\mathrm{C}_{2} \mathrm{O}_{4} \\
(\mathrm{mg} / \mathrm{kg})\end{array}$ & $\begin{array}{c}\text { TIC } \\
(\mathrm{mg} / \mathrm{kg})\end{array}$ & $\begin{array}{c}\text { TOC } \\
(\mathrm{mg} / \mathrm{kg})\end{array}$ \\
\hline A4-LD-00 & 0 & 5.37 & 3430 & 97100 & 1040 & 1.58 & 2.66 & $<19.4$ & 24000 & 9710 & 313 & 897 & 1310 & 7845 & 424 \\
\hline A4-LD-06 & 6 & 4.47 & 3540 & 93000 & 1040 & 1.46 & 2.14 & $<27.2$ & 22600 & 9190 & 290 & 835 & 1190 & 7540 & 412 \\
\hline A4-LD-12 & 12 & 3.63 & 3390 & 93900 & 1010 & 1.44 & 2.12 & $<40.8$ & 22300 & 9150 & 303 & 838 & 1180 & 7550 & 407 \\
\hline A4-LD-18 & 18 & 3.19 & 3720 & 92800 & 999 & 1.46 & 2.12 & $<27.0$ & 22900 & 9170 & 291 & 849 & 1210 & 7705 & 401 \\
\hline A4-LD-24 & 24 & 2.89 & 3570 & 94300 & 1030 & 1.46 & 2.16 & $<34.2$ & 22900 & 9340 & 298 & 861 & 1220 & 7610 & 409 \\
\hline A4-LD-48 & 48 & 2.00 & 3420 & 94200 & 1060 & 1.47 & 2.17 & $<30.9$ & 23100 & 9380 & 293 & 869 & 1200 & 7550 & 408 \\
\hline A4-LD-60 & 60 & 1.69 & 3310 & 90700 & 960 & 1.54 & 2.28 & $<30.9$ & 23100 & 9460 & 320 & 871 & 1210 & 7420 & 403 \\
\hline A4-LD-80 & 80 & 1.39 & 3270 & 90300 & 980 & 1.40 & 2.08 & $<26.3$ & 22100 & 9020 & 276 & 839 & 1140 & 7680 & 425 \\
\hline A4-LD-120 & 120 & 1.09 & 3440 & 90300 & 994 & 1.36 & 1.99 & $<27.7$ & 22300 & 8950 & 294 & 838 & 1200 & 7590 & 385 \\
\hline A4-LD-180 & 180 & 0.932 & 3370 & 91600 & 1010 & 1.42 & 2.08 & $<27.5$ & 22100 & 8930 & 283 & 825 & 1160 & 7485 & 415 \\
\hline A4-LD-240 & 240 & 0.865 & 3410 & 91400 & 1040 & 1.45 & 2.12 & $<29.4$ & 22400 & 9030 & 288 & 842 & 1180 & 7535 & 407 \\
\hline A4-FD-CP & $\begin{array}{c}\text { Feed } \\
\text { Displacement }\end{array}$ & 0.542 & 2100 & 55800 & 622 & 0.847 & 1.22 & $<33.0$ & 12800 & 5370 & 211 & 491 & 726 & 4100 & 266 \\
\hline Target & -- & 4.86 & 3280 & 93200 & 951 & 1.20 & 2.01 & 0 & 23100 & 9430 & 326 & 856 & 1210 & 7960 & 408 \\
\hline
\end{tabular}


Table B.5. Column A4B Test Analytical Data $\left(\mathrm{T}=60^{\circ} \mathrm{C}\right.$, Flow rate $\left.=0.08 \mathrm{~mL} / \mathrm{min}\right)$

\begin{tabular}{|c|c|c|c|c|c|c|c|c|c|c|c|c|c|c|c|}
\hline Sample ID & $\begin{array}{l}\text { Loading Time } \\
\text { (hr) }\end{array}$ & $\begin{array}{c}\mathrm{Cs} \\
(\mathrm{mg} / \mathrm{kg})\end{array}$ & $\begin{array}{c}\mathrm{Al} \\
(\mathrm{mg} / \mathrm{kg})\end{array}$ & $\begin{array}{c}\mathrm{Na} \\
(\mathrm{mg} / \mathrm{kg})\end{array}$ & $\begin{array}{c}\mathrm{K} \\
(\mathrm{mg} / \mathrm{kg})\end{array}$ & $\begin{array}{l}\text { OH-Free } \\
(\mathrm{meq} / \mathrm{mL})\end{array}$ & $\begin{array}{l}\text { OH-Total } \\
(\mathrm{meq} / \mathrm{mL})\end{array}$ & $\begin{array}{c}\mathrm{Cl} \\
(\mathrm{mg} / \mathrm{kg})\end{array}$ & $\begin{array}{c}\mathrm{NO}_{3} \\
(\mathrm{mg} / \mathrm{kg})\end{array}$ & $\begin{array}{c}\mathrm{NO}_{2} \\
(\mathrm{mg} / \mathrm{kg})\end{array}$ & $\begin{array}{c}\mathrm{PO}_{4} \\
(\mathrm{mg} / \mathrm{kg})\end{array}$ & $\begin{array}{c}\mathrm{SO}_{4} \\
(\mathrm{mg} / \mathrm{kg})\end{array}$ & $\begin{array}{c}\mathrm{C}_{2} \mathrm{O}_{4} \\
(\mathrm{mg} / \mathrm{kg})\end{array}$ & $\begin{array}{c}\text { TIC } \\
(\mathrm{mg} / \mathrm{kg})\end{array}$ & $\begin{array}{c}\text { TOC } \\
(\mathrm{mg} / \mathrm{kg})\end{array}$ \\
\hline A4B-LD-00 & 0 & 5.19 & 3590 & 94400 & 1090 & 1.49 & 2.17 & $<32.7$ & 22400 & 9320 & 298 & 797 & 1110 & 8065 & 421 \\
\hline A4B-LD-04 & 4 & 4.86 & 3490 & 90700 & 1050 & 1.42 & 2.09 & $<33.1$ & 21700 & 9120 & 292 & 786 & 1110 & 7835 & 410 \\
\hline A4B-LD-08 & 8 & 4.60 & 3440 & 91600 & 1030 & 1.43 & 2.10 & $<33.1$ & 21700 & 9030 & 284 & 789 & 1130 & 7675 & 410 \\
\hline A4B-LD-12 & 12 & 4.38 & 3510 & 93400 & 1060 & 1.43 & 2.10 & $<32.6$ & 21500 & 8830 & 276 & 805 & 1150 & 8055 & 415 \\
\hline A4B-LD-24 & 24 & 3.73 & 3530 & 91400 & 1090 & 1.44 & 2.11 & $<32.7$ & 21800 & 9060 & 282 & 785 & 1120 & 8135 & 406 \\
\hline A4B-LD-72 & 72 & 2.65 & 3630 & 95400 & 1110 & 1.47 & 2.16 & $<32.9$ & 22500 & 9450 & 285 & 805 & 995 & 8215 & 421 \\
\hline A4B-LD-120 & 120 & 2.88 & 3620 & 95400 & 1090 & 1.51 & 2.22 & $<32.7$ & 22600 & 9260 & 290 & 817 & 1060 & 8415 & 447 \\
\hline A4B-LD-168 & 168 & 2.99 & 3780 & 99100 & 1140 & 1.54 & 2.26 & $<32.5$ & 23400 & 9560 & 289 & 833 & 843 & 8985 & 458 \\
\hline A4B-LD-336 & 336 & 3.21 & 3900 & 102000 & 1160 & 1.62 & 2.39 & $<33.7$ & 24600 & 10200 & 308 & 884 & 794 & 8795 & 351 \\
\hline A4B-FD-CP & $\begin{array}{c}\text { Feed } \\
\text { Displacement }\end{array}$ & 2.00 & 2240 & 62400 & 2240 & 0.998 & 1.41 & $<36.4$ & 14200 & 6320 & 190 & 512 & 796 & 4705 & 369 \\
\hline A4B-EL-CP & Elution & 20.0 & 38.9 & 1270 & 39.5 & $<0.05$ & $<0.05$ & $<40.1$ & 3020 & $<40.1$ & $<40.1$ & $<40.1$ & $<40.1$ & $<25.0$ & $<10.0$ \\
\hline Target & -- & 4.86 & 3280 & 93200 & 951 & 1.20 & 2.01 & 0 & 23100 & 9430 & 326 & 856 & 1210 & 7960 & 408 \\
\hline
\end{tabular}


Table B.6. Column A5 Test Analytical Data $\left(\mathrm{T}=45^{\circ} \mathrm{C}\right.$, Flow rate $\left.=10.62 \mathrm{~mL} / \mathrm{min}\right)$

\begin{tabular}{|c|c|c|c|c|c|c|c|c|c|c|c|c|c|c|c|}
\hline Sample ID & $\begin{array}{l}\text { Loading Time } \\
\text { (min) }\end{array}$ & $\begin{array}{c}\mathrm{Cs} \\
(\mathrm{mg} / \mathrm{kg}) \\
\end{array}$ & $\begin{array}{c}\mathrm{Al} \\
(\mathrm{mg} / \mathrm{kg})\end{array}$ & $\begin{array}{c}\mathrm{Na} \\
(\mathrm{mg} / \mathrm{kg})\end{array}$ & $\begin{array}{c}\mathrm{K} \\
(\mathrm{mg} / \mathrm{kg})\end{array}$ & $\begin{array}{c}\text { OH-Free } \\
(\mathrm{meq} / \mathrm{mL})\end{array}$ & $\begin{array}{l}\text { OH-Total } \\
(\mathrm{meq} / \mathrm{mL})\end{array}$ & $\begin{array}{c}\mathrm{Cl} \\
(\mathrm{mg} / \mathrm{kg})\end{array}$ & $\begin{array}{c}\mathrm{NO}_{3} \\
(\mathrm{mg} / \mathrm{kg})\end{array}$ & $\begin{array}{c}\mathrm{NO}_{2} \\
(\mathrm{mg} / \mathrm{kg})\end{array}$ & $\begin{array}{c}\mathrm{PO}_{4} \\
(\mathrm{mg} / \mathrm{kg})\end{array}$ & $\begin{array}{c}\mathrm{SO}_{4} \\
(\mathrm{mg} / \mathrm{kg})\end{array}$ & $\begin{array}{c}\mathrm{C}_{2} \mathrm{O}_{4} \\
(\mathrm{mg} / \mathrm{kg})\end{array}$ & $\begin{array}{c}\text { TIC } \\
(\mathrm{mg} / \mathrm{kg})\end{array}$ & $\begin{array}{c}\text { TOC } \\
(\mathrm{mg} / \mathrm{kg})\end{array}$ \\
\hline A5-LD-00 & 0 & 5.15 & 3520 & 92900 & 1070 & 1.49 & 2.18 & $<32.4$ & 22500 & 9160 & 275 & 805 & 814 & 8065 & 346 \\
\hline A5-LD-06 & 6 & 4.18 & 3520 & 90200 & 1020 & 1.45 & 2.11 & $<32.7$ & 21600 & 8820 & 265 & 772 & 811 & 7875 & 336 \\
\hline A5-LD-12 & 12 & 3.53 & 3380 & 90000 & 1010 & 1.45 & 2.09 & $<33.2$ & 21600 & 8850 & 269 & 780 & 814 & 7555 & 337 \\
\hline A5-LD-18 & 18 & 3.12 & 3460 & 89900 & 1010 & 1.43 & 2.10 & $<32.9$ & 21400 & 9180 & 259 & 778 & 826 & 7525 & 325 \\
\hline A5-LD-24 & 24 & 2.83 & 3480 & 90600 & 1020 & 1.45 & 2.11 & $<32.6$ & 21400 & 8740 & 260 & 759 & 767 & 7740 & 326 \\
\hline A5-LD-48 & 48 & 1.90 & 3390 & 88500 & 1000 & 1.42 & 2.09 & $<32.8$ & 21400 & 8880 & 256 & 781 & 805 & 7440 & 325 \\
\hline A5-LD-60 & 60 & 1.69 & 3440 & 90800 & 990 & 1.43 & 2.08 & $<33.1$ & 21200 & 8800 & 262 & 769 & 802 & 7400 & 330 \\
\hline A5-LD-80 & 80 & 1.45 & 3400 & 89500 & 994 & 1.43 & 2.09 & $<32.7$ & 21600 & 8980 & 264 & 776 & 776 & 7675 & 327 \\
\hline A5-LD-120 & 120 & 1.19 & 3380 & 87800 & 990 & 1.43 & 2.09 & $<32.8$ & 21600 & 8910 & 270 & 772 & 818 & 7510 & 324 \\
\hline A5-LD-180 & 180 & 1.03 & 3410 & 87600 & 980 & 1.43 & 2.10 & $<32.7$ & 21500 & 9090 & 263 & 774 & 823 & 7685 & 325 \\
\hline A5-LD-240 & 240 & 1.01 & 3520 & 89600 & 1000 & 1.43 & 2.07 & $<32.8$ & 21700 & 9040 & 257 & 772 & 813 & 7690 & 330 \\
\hline A5-FD-CP & $\begin{array}{c}\text { Feed } \\
\text { Displacement }\end{array}$ & 0.734 & 2150 & 59100 & 650 & 0.926 & 1.32 & $<36.2$ & 13400 & 5610 & 192 & 479 & 510 & 4465 & 234 \\
\hline Target & -- & 4.86 & 3280 & 93200 & 951 & 1.20 & 2.01 & 0 & 23100 & 9430 & 326 & 856 & 1210 & 7960 & 408 \\
\hline
\end{tabular}


Table B.7. Column B1 Test Analytical Data $\left(\mathrm{T}=40^{\circ} \mathrm{C}\right.$, Flow rate $\left.=10.62 \mathrm{~mL} / \mathrm{min}\right)$

\begin{tabular}{|c|c|c|c|c|c|c|c|c|c|c|c|c|c|c|c|}
\hline Sample ID & $\begin{array}{l}\text { Loading Time } \\
(\mathrm{min})\end{array}$ & $\begin{array}{c}\mathrm{Cs} \\
(\mathrm{mg} / \mathrm{kg})\end{array}$ & $\begin{array}{c}\mathrm{Al} \\
(\mathrm{mg} / \mathrm{kg})\end{array}$ & $\begin{array}{c}\mathrm{Na} \\
(\mathrm{mg} / \mathrm{kg})\end{array}$ & $\begin{array}{c}\mathrm{K} \\
(\mathrm{mg} / \mathrm{kg}) \\
\end{array}$ & $\begin{array}{c}\text { OH-Free } \\
(\mathrm{meq} / \mathrm{mL})\end{array}$ & $\begin{array}{l}\text { OH-Total } \\
(\mathrm{meq} / \mathrm{mL})\end{array}$ & $\begin{array}{c}\mathrm{Cl} \\
(\mathrm{mg} / \mathrm{kg}) \\
\end{array}$ & $\begin{array}{c}\mathrm{NO}_{3} \\
(\mathrm{mg} / \mathrm{kg}) \\
\end{array}$ & $\begin{array}{c}\mathrm{NO}_{2} \\
(\mathrm{mg} / \mathrm{kg})\end{array}$ & $\begin{array}{c}\mathrm{PO}_{4} \\
(\mathrm{mg} / \mathrm{kg}) \\
\end{array}$ & $\begin{array}{c}\mathrm{SO}_{4} \\
(\mathrm{mg} / \mathrm{kg}) \\
\end{array}$ & $\begin{array}{c}\mathrm{C}_{2} \mathrm{O}_{4} \\
(\mathrm{mg} / \mathrm{kg}) \\
\end{array}$ & $\begin{array}{c}\mathrm{TIC} \\
(\mathrm{mg} / \mathrm{kg})\end{array}$ & $\begin{array}{c}\text { TOC } \\
(\mathrm{mg} / \mathrm{kg})\end{array}$ \\
\hline B1-LD-00 & 0 & 5.24 & 3570 & 96400 & 1030 & 1.50 & 2.19 & $<64.2$ & 22900 & 9160 & 311 & 835 & 1190 & 7980 & 426 \\
\hline B1-LD-06 & 6 & 4.05 & 3500 & 91400 & 952 & 1.46 & 2.13 & $<65.0$ & 22500 & 8980 & 306 & 821 & 1180 & 7820 & 409 \\
\hline B1-LD-12 & 12 & 3.53 & 3480 & 92900 & 975 & 1.46 & 2.13 & $<64.7$ & 22300 & 8930 & 303 & 829 & 1170 & 7965 & 412 \\
\hline B1-LD-18 & 18 & 3.03 & 3550 & 92600 & 974 & 1.46 & 2.13 & $<32.4$ & 21700 & 8800 & 286 & 815 & 1140 & 7965 & 409 \\
\hline B1-LD-24 & 24 & 2.63 & 3370 & 91800 & 983 & 1.47 & 2.13 & $<64.9$ & 22400 & 8970 & 293 & 806 & 1140 & 8060 & 416 \\
\hline B1-LD-48 & 48 & 1.86 & 3510 & 95300 & 971 & 1.46 & 2.12 & $<64.9$ & 22200 & 8860 & 294 & 815 & 1140 & 8075 & 414 \\
\hline B1-LD-60 & 60 & 1.62 & 3510 & 95800 & 985 & 1.46 & 2.13 & $<65.0$ & 22300 & 9040 & 293 & 823 & 1140 & 7755 & 406 \\
\hline B1-LD-80 & 80 & 1.38 & 3510 & 93200 & 973 & 1.46 & 2.13 & $<65.5$ & 22200 & 8850 & 294 & 835 & 1150 & 7915 & 413 \\
\hline B1-LD-120 & 120 & 1.09 & 3460 & 91900 & 963 & 1.45 & 2.12 & $<65.1$ & 22500 & 8990 & 292 & 810 & 1150 & 8415 & 413 \\
\hline B1-LD-180 & 180 & 0.877 & 3490 & 93400 & 972 & 1.44 & 2.11 & $<65.0$ & 22300 & 8930 & 302 & 825 & 1160 & 7880 & 411 \\
\hline B1-LD-240 & 240 & 0.768 & 3610 & 96600 & 976 & 1.46 & 2.12 & $<65.3$ & 22300 & 8930 & 294 & 823 & 1170 & 7840 & 415 \\
\hline B1-FD-CP & $\begin{array}{c}\text { Feed } \\
\text { Displacement }\end{array}$ & 0.415 & 1920 & 53700 & 560 & 0.720 & 0.832 & $<73.8$ & 12100 & 5300 & 169 & 458 & 659 & 4010 & 223 \\
\hline B1-EL-CP & Elution & 13.3 & $<2.00$ & 1200 & 60.5 & $<0.05$ & $<0.05$ & $<79.7$ & 2430 & $<79.7$ & $<79.7$ & $<79.7$ & $<79.7$ & $<25.0$ & $<10.0$ \\
\hline Target & -- & 4.86 & 3280 & 93200 & 951 & 1.20 & 2.01 & 0 & 23100 & 9430 & 326 & 856 & 1210 & 7960 & 408 \\
\hline
\end{tabular}


Table B.8. Column B2 Test Analytical Data $\left(T=40^{\circ} \mathrm{C}\right.$, Flow rate $\left.=14.16 \mathrm{~mL} / \mathrm{min}\right)$

\begin{tabular}{|c|c|c|c|c|c|c|c|c|c|c|c|c|c|c|c|}
\hline Sample ID & $\begin{array}{l}\text { Loading Time } \\
\text { (min) }\end{array}$ & $\begin{array}{c}\mathrm{Cs} \\
(\mathrm{mg} / \mathrm{kg})\end{array}$ & $\begin{array}{c}\mathrm{Al} \\
(\mathrm{mg} / \mathrm{kg})\end{array}$ & $\begin{array}{c}\mathrm{Na} \\
(\mathrm{mg} / \mathrm{kg})\end{array}$ & $\begin{array}{c}\mathrm{K} \\
(\mathrm{mg} / \mathrm{kg})\end{array}$ & $\begin{array}{l}\text { OH-Free } \\
\text { (meq/mL) }\end{array}$ & $\begin{array}{l}\text { OH-Total } \\
\text { (meq/mL) }\end{array}$ & $\begin{array}{c}\mathrm{Cl} \\
(\mathrm{mg} / \mathrm{kg})\end{array}$ & $\begin{array}{c}\mathrm{NO}_{3} \\
(\mathrm{mg} / \mathrm{kg})\end{array}$ & $\begin{array}{c}\mathrm{NO}_{2} \\
(\mathrm{mg} / \mathrm{kg})\end{array}$ & $\begin{array}{c}\mathrm{PO}_{4} \\
(\mathrm{mg} / \mathrm{kg})\end{array}$ & $\begin{array}{c}\mathrm{SO}_{4} \\
(\mathrm{mg} / \mathrm{kg})\end{array}$ & $\begin{array}{c}\mathrm{C}_{2} \mathrm{O}_{4} \\
(\mathrm{mg} / \mathrm{kg})\end{array}$ & $\begin{array}{c}\text { TIC } \\
(\mathrm{mg} / \mathrm{kg})\end{array}$ & $\begin{array}{c}\text { TOC } \\
(\mathrm{mg} / \mathrm{kg})\end{array}$ \\
\hline B2-LD-00 & 0 & 5.22 & 3590 & 92900 & 1020 & 1.49 & 2.18 & $<63.5$ & 23200 & 9300 & 297 & 834 & 1180 & 8130 & 413 \\
\hline B2-LD-06 & 6 & 4.09 & 3350 & 88600 & 974 & 1.45 & 2.10 & $<64.2$ & 22100 & 8850 & 287 & 802 & 1100 & 7620 & 400 \\
\hline B2-LD-12 & 12 & 3.38 & 3430 & 87900 & 1030 & 1.44 & 2.10 & $<63.7$ & 22000 & 8800 & 284 & 809 & 1110 & 7565 & 402 \\
\hline B2-LD-18 & 18 & 3.00 & 3620 & 90800 & 984 & 1.45 & 2.11 & $<63.7$ & 22400 & 8970 & 287 & 806 & 1110 & 7475 & 399 \\
\hline B2-LD-24 & 24 & 2.62 & 3320 & 89300 & 994 & 1.45 & 2.11 & $<63.6$ & 22400 & 8970 & 289 & 820 & 1110 & 7500 & 404 \\
\hline B2-LD-48 & 48 & 1.83 & 3430 & 90500 & 983 & 1.45 & 2.10 & $<63.9$ & 21900 & 8860 & 267 & 790 & 1070 & 7725 & 395 \\
\hline B2-LD-60 & 60 & 1.62 & 3470 & 90600 & 969 & 1.45 & 2.09 & $<63.8$ & 21900 & 8740 & 282 & 816 & 1090 & 7585 & 392 \\
\hline B2-LD-80 & 80 & 1.37 & 3590 & 90300 & 1000 & 1.43 & 2.09 & $<63.8$ & 22200 & 9040 & 276 & 809 & 1090 & 7555 & 396 \\
\hline B2-LD-120 & 120 & 1.08 & 3460 & 89500 & 972 & 1.45 & 2.11 & $<64.0$ & 22200 & 8860 & 281 & 794 & 1090 & 7570 & 396 \\
\hline B2-LD-180 & 180 & 0.888 & 3510 & 89500 & 979 & 1.45 & 2.10 & $<63.6$ & 22500 & 9000 & 268 & 786 & 1070 & 7660 & 399 \\
\hline B2-LD-240 & 240 & 0.803 & 3460 & 90500 & 957 & 1.44 & 2.09 & $<63.8$ & 22200 & 8850 & 283 & 812 & 1110 & 7710 & 402 \\
\hline B2-FD-CP & $\begin{array}{c}\text { Feed } \\
\text { Displacement }\end{array}$ & 0.426 & 1940 & 52500 & 556 & 0.707 & 0.822 & $<70.5$ & 11900 & 5100 & 162 & 446 & 621 & 3900 & 210 \\
\hline B2-EL-CP & Elution & 16.1 & 4.33 & 1320 & 64.5 & $<0.05$ & $<0.05$ & $<78.7$ & 3000 & $<78.7$ & $<78.7$ & $<78.7$ & $<78.7$ & $<25.0$ & $<10.0$ \\
\hline Target & -- & 4.86 & 3280 & 93200 & 951 & 1.20 & 2.01 & 0 & 23100 & 9430 & 326 & 856 & 1210 & 7960 & 408 \\
\hline
\end{tabular}


Table B.9. Column B3 Test Analytical Data $\left(\mathrm{T}=40^{\circ} \mathrm{C}\right.$, Flow rate $\left.=7.08 \mathrm{~mL} / \mathrm{min}\right)$

\begin{tabular}{|c|c|c|c|c|c|c|c|c|c|c|c|c|c|c|c|}
\hline Sample ID & $\begin{array}{l}\text { Loading Time } \\
(\min )\end{array}$ & $\begin{array}{c}\mathrm{Cs} \\
(\mathrm{mg} / \mathrm{kg})\end{array}$ & $\begin{array}{c}\mathrm{Al} \\
(\mathrm{mg} / \mathrm{kg})\end{array}$ & $\begin{array}{c}\mathrm{Na} \\
(\mathrm{mg} / \mathrm{kg})\end{array}$ & $\begin{array}{c}\mathrm{K} \\
(\mathrm{mg} / \mathrm{kg})\end{array}$ & $\begin{array}{c}\text { OH-Free } \\
(\mathrm{meq} / \mathrm{mL})\end{array}$ & $\begin{array}{l}\text { OH-Total } \\
(\mathrm{meq} / \mathrm{mL})\end{array}$ & $\begin{array}{c}\mathrm{Cl} \\
(\mathrm{mg} / \mathrm{kg})\end{array}$ & $\begin{array}{c}\mathrm{NO}_{3} \\
(\mathrm{mg} / \mathrm{kg})\end{array}$ & $\begin{array}{c}\mathrm{NO}_{2} \\
(\mathrm{mg} / \mathrm{kg})\end{array}$ & $\begin{array}{c}\mathrm{PO}_{4} \\
(\mathrm{mg} / \mathrm{kg})\end{array}$ & $\begin{array}{c}\mathrm{SO}_{4} \\
(\mathrm{mg} / \mathrm{kg})\end{array}$ & $\begin{array}{c}\mathrm{C}_{2} \mathrm{O}_{4} \\
(\mathrm{mg} / \mathrm{kg})\end{array}$ & $\begin{array}{c}\text { TIC } \\
\text { (mg/kg) }\end{array}$ & $\begin{array}{c}\text { TOC } \\
(\mathrm{mg} / \mathrm{kg})\end{array}$ \\
\hline B3-LD-00 & 0 & 5.48 & 3650 & 96800 & 1100 & 1.51 & 2.19 & $<32.3$ & 23700 & 9550 & 367 & 868 & 1200 & 8000 & 433 \\
\hline B3-LD-06 & 6 & 4.56 & 3500 & 93200 & 1040 & 1.45 & 2.11 & $<32.2$ & 22800 & 9220 & 318 & 807 & 1540 & 7860 & 421 \\
\hline B3-LD-12 & 12 & 3.95 & 3480 & 91900 & 1020 & 1.45 & 2.10 & $<32.4$ & 22800 & 9210 & 300 & 841 & 1180 & 8185 & 425 \\
\hline B3-LD-18 & 18 & 3.52 & 3430 & 93000 & 1070 & 1.46 & 2.12 & $<32.7$ & 22800 & 9240 & 317 & 839 & 1170 & 8015 & 423 \\
\hline B3-LD-24 & 24 & 3.16 & 3570 & 93700 & 1040 & 1.46 & 2.12 & $<32.5$ & 22500 & 9080 & 293 & 836 & 1160 & 7685 & 414 \\
\hline B3-LD-48 & 48 & 2.17 & 3620 & 92300 & 1030 & 1.44 & 2.11 & $<32.5$ & 22900 & 9210 & 287 & 829 & 1130 & 7845 & 413 \\
\hline B3-LD-60 & 60 & 1.91 & 3380 & 92200 & 977 & 1.45 & 2.10 & $<32.1$ & 22400 & 9020 & 286 & 833 & 1130 & 8155 & 420 \\
\hline B3-LD-80 & 80 & 1.57 & 3530 & 93000 & 1030 & 1.45 & 2.11 & $<32.3$ & 22500 & 9080 & 282 & 833 & 1120 & 7985 & 418 \\
\hline B3-LD-120 & 120 & 1.19 & 3490 & 92800 & 1040 & 1.44 & 2.11 & $<32.3$ & 22600 & 9170 & 296 & 840 & 1160 & 7855 & 418 \\
\hline B3-LD-180 & 180 & 0.926 & 3420 & 91900 & 1050 & 1.46 & 2.12 & $<34.7$ & 22600 & 9140 & 302 & 847 & 1220 & 8070 & 420 \\
\hline B3-LD-240 & 240 & 0.821 & 3540 & 92400 & 1020 & 1.45 & 2.11 & $<31.8$ & 22300 & 9010 & 290 & 825 & 1130 & 7820 & 429 \\
\hline B3-FD-CP & $\begin{array}{c}\text { Feed } \\
\text { Displacement }\end{array}$ & 0.442 & 1860 & 53300 & 575 & 0.697 & 1.14 & $<36.6$ & 11900 & 4990 & 180 & 465 & 665 & 3745 & 219 \\
\hline B3-EL-CP & Elution & 17.3 & 2.39 & 1360 & 64.9 & $<0.05$ & $<0.05$ & $<39.7$ & 3250 & $<39.7$ & $<39.7$ & $<39.7$ & $<39.7$ & $<25.0$ & $<10.0$ \\
\hline Target & -- & 4.86 & 3280 & 93200 & 951 & 1.20 & 2.01 & 0 & 23100 & 9430 & 326 & 856 & 1210 & 7960 & 408 \\
\hline
\end{tabular}


Table B.10. Column B4 Test Analytical Data $\left(\mathrm{T}=40^{\circ} \mathrm{C}\right.$, Flow rate $\left.=10.62 \mathrm{~mL} / \mathrm{min}\right)$

\begin{tabular}{|c|c|c|c|c|c|c|c|c|c|c|c|c|c|c|c|}
\hline Sample ID & $\begin{array}{l}\text { Loading Time } \\
\text { (min) }\end{array}$ & $\begin{array}{c}\mathrm{Cs} \\
(\mathrm{mg} / \mathrm{kg})\end{array}$ & $\begin{array}{c}\mathrm{Al} \\
(\mathrm{mg} / \mathrm{kg})\end{array}$ & $\begin{array}{c}\mathrm{Na} \\
(\mathrm{mg} / \mathrm{kg})\end{array}$ & $\begin{array}{c}\mathrm{K} \\
(\mathrm{mg} / \mathrm{kg})\end{array}$ & $\begin{array}{l}\text { OH-Free } \\
\text { (meq/mL) }\end{array}$ & $\begin{array}{l}\text { OH-Total } \\
(\mathrm{meq} / \mathrm{mL})\end{array}$ & $\begin{array}{c}\mathrm{Cl} \\
(\mathrm{mg} / \mathrm{kg})\end{array}$ & $\begin{array}{c}\mathrm{NO}_{3} \\
(\mathrm{mg} / \mathrm{kg})\end{array}$ & $\begin{array}{c}\mathrm{NO}_{2} \\
(\mathrm{mg} / \mathrm{kg})\end{array}$ & $\begin{array}{c}\mathrm{PO}_{4} \\
(\mathrm{mg} / \mathrm{kg})\end{array}$ & $\begin{array}{c}\mathrm{SO}_{4} \\
(\mathrm{mg} / \mathrm{kg})\end{array}$ & $\begin{array}{c}\mathrm{C}_{2} \mathrm{O}_{4} \\
(\mathrm{mg} / \mathrm{kg})\end{array}$ & $\begin{array}{c}\text { TIC } \\
(\mathrm{mg} / \mathrm{kg})\end{array}$ & $\begin{array}{c}\text { TOC } \\
(\mathrm{mg} / \mathrm{kg})\end{array}$ \\
\hline B4-LD-00 & 0 & 5.20 & 3640 & 94700 & 1080 & 1.49 & 2.17 & $<48.8$ & 22700 & 9180 & 369 & 851 & 1200 & 7960 & 426 \\
\hline B4-LD-06 & 6 & 4.18 & 3410 & 90200 & 1020 & 1.45 & 2.10 & $<49.8$ & 22400 & 9080 & 303 & 843 & 1220 & 7585 & 413 \\
\hline B4-LD-12 & 12 & 3.59 & 3340 & 93500 & 1030 & 1.43 & 2.10 & $<49.4$ & 22400 & 9120 & 301 & 820 & 1170 & 7515 & 405 \\
\hline B4-LD-18 & 18 & 3.12 & 3410 & 93000 & 1030 & 1.45 & 2.10 & $<49.3$ & 22000 & 8910 & 287 & 809 & 1150 & 7640 & 404 \\
\hline B4-LD-24 & 24 & 2.75 & 3510 & 92700 & 1020 & 1.46 & 2.11 & $<48.5$ & 21700 & 8830 & 292 & 819 & 1150 & 7775 & 406 \\
\hline B4-LD-48 & 48 & 1.90 & 3390 & 93600 & 1040 & 1.44 & 2.09 & $<49.4$ & 22400 & 9080 & 291 & 835 & 1170 & 7655 & 407 \\
\hline B4-LD-60 & 60 & 1.67 & 3430 & 91900 & 1050 & 1.44 & 2.09 & $<49.3$ & 22300 & 9120 & 281 & 829 & 1080 & 7570 & 407 \\
\hline B4-LD-80 & 80 & 1.40 & 3550 & 93900 & 1070 & 1.44 & 2.09 & $<49.5$ & 22000 & 8950 & 281 & 817 & 1120 & 7710 & 409 \\
\hline B4-LD-120 & 120 & 1.09 & 3520 & 92900 & 1010 & 1.44 & 2.09 & $<49.8$ & 22100 & 8950 & 298 & 833 & 1170 & 7710 & 412 \\
\hline B4-LD-180 & 180 & 0.891 & 3690 & 93400 & 1020 & 1.44 & 2.09 & $<49.0$ & 22100 & 8940 & 294 & 832 & 1180 & 7840 & 410 \\
\hline B4-LD-240 & 240 & 0.800 & 3480 & 93500 & 1030 & 1.45 & 2.11 & $<49.7$ & 22200 & 9000 & 295 & 843 & 1160 & 7940 & 411 \\
\hline B4-FD-CP & $\begin{array}{c}\text { Feed } \\
\text { Displacement }\end{array}$ & 0.418 & 1790 & 50800 & 536 & 0.640 & 1.07 & $<55.6$ & 11000 & 4670 & 190 & 420 & 626 & 3800 & 210 \\
\hline Target & -- & 4.86 & 3280 & 93200 & 951 & 1.20 & 2.01 & 0 & 23100 & 9430 & 326 & 856 & 1210 & 7960 & 408 \\
\hline
\end{tabular}


Table B.11. Column B4B Test Analytical Data $\left(T=55^{\circ} \mathrm{C}\right.$, Flow rate $\left.=0.08 \mathrm{~mL} / \mathrm{min}\right)$

\begin{tabular}{|c|c|c|c|c|c|c|c|c|c|c|c|c|c|c|c|}
\hline Sample ID & $\begin{array}{l}\text { Loading Time } \\
(\mathrm{hr})\end{array}$ & $\begin{array}{c}\mathrm{Cs} \\
(\mathrm{mg} / \mathrm{kg})\end{array}$ & $\begin{array}{c}\mathrm{Al} \\
(\mathrm{mg} / \mathrm{kg})\end{array}$ & $\begin{array}{c}\mathrm{Na} \\
(\mathrm{mg} / \mathrm{kg})\end{array}$ & $\begin{array}{c}\mathrm{K} \\
(\mathrm{mg} / \mathrm{kg})\end{array}$ & $\begin{array}{l}\text { OH-Free } \\
(\mathrm{meq} / \mathrm{mL})\end{array}$ & $\begin{array}{l}\text { OH-Total } \\
(\mathrm{meq} / \mathrm{mL})\end{array}$ & $\begin{array}{c}\mathrm{Cl} \\
(\mathrm{mg} / \mathrm{kg})\end{array}$ & $\begin{array}{c}\mathrm{NO}_{3} \\
(\mathrm{mg} / \mathrm{kg})\end{array}$ & $\begin{array}{c}\mathrm{NO}_{2} \\
(\mathrm{mg} / \mathrm{kg})\end{array}$ & $\begin{array}{c}\mathrm{PO}_{4} \\
(\mathrm{mg} / \mathrm{kg})\end{array}$ & $\begin{array}{c}\mathrm{SO}_{4} \\
(\mathrm{mg} / \mathrm{kg})\end{array}$ & $\begin{array}{c}\mathrm{C}_{2} \mathrm{O}_{4} \\
(\mathrm{mg} / \mathrm{kg})\end{array}$ & $\begin{array}{c}\text { TIC } \\
(\mathrm{mg} / \mathrm{kg})\end{array}$ & $\begin{array}{c}\text { TOC } \\
(\mathrm{mg} / \mathrm{kg})\end{array}$ \\
\hline B4B-LD-00 & 0 & 5.25 & 3630 & 93600 & 1090 & 1.48 & 2.15 & $<32.8$ & 22100 & 9370 & 280 & 814 & 1110 & 8050 & 403 \\
\hline B4B-LD-04 & 4 & 4.86 & 3460 & 91700 & 1050 & 1.42 & 2.08 & $<32.8$ & 21600 & 8950 & 272 & 793 & 1130 & 7995 & 398 \\
\hline B4B-LD-08 & 8 & 4.60 & 3590 & 93800 & 1090 & 1.41 & 2.07 & $<32.7$ & 21400 & 8870 & 269 & 777 & 1090 & 8035 & 403 \\
\hline B4B-LD-12 & 12 & 4.27 & 3520 & 90400 & 1050 & 1.43 & 2.11 & $<32.8$ & 21600 & 9200 & 261 & 783 & 1070 & 8070 & 399 \\
\hline B4B-LD-24 & 24 & 3.49 & 3480 & 91500 & 1050 & 1.42 & 2.08 & $<33.2$ & 21800 & 8930 & 264 & 790 & 1050 & 7865 & 411 \\
\hline B4B-LD-120 & 120 & 2.67 & 3680 & 96700 & 1120 & 1.49 & 2.19 & $<32.6$ & 22800 & 9690 & 273 & 825 & 1100 & 8520 & 441 \\
\hline B4B-LD-168 & 168 & 2.76 & 3730 & 94800 & 1120 & 1.54 & 2.25 & $<32.4$ & 23200 & 9420 & 276 & 830 & 1010 & 8385 & 462 \\
\hline B4B-LD-336 & 336 & 3.12 & 4300 & 107000 & 1240 & 1.82 & 2.64 & $<31.6$ & 28100 & 11000 & 419 & 1000 & 1350 & 9725 & 545 \\
\hline B4B-FD-CP & $\begin{array}{c}\text { Feed } \\
\text { Displacement }\end{array}$ & 2.38 & 2970 & 79700 & 905 & 1.32 & 1.88 & $<33.4$ & 20200 & 7900 & 315 & 731 & 1600 & 6530 & 607 \\
\hline B4B-EL-CP & Elution & 27.1 & 18.8 & 1310 & 47.0 & $<0.05$ & $<0.05$ & $<39.7$ & 3190 & $<39.7$ & $<39.7$ & $<39.7$ & $<39.7$ & $<25.0$ & $<10.0$ \\
\hline
\end{tabular}


Table B.12. Column B5 Test Analytical Data $\left(\mathrm{T}=40^{\circ} \mathrm{C}\right.$, Flow rate $\left.=10.62 \mathrm{~mL} / \mathrm{min}\right)$

\begin{tabular}{|c|c|c|c|c|c|c|c|c|c|c|c|c|c|c|c|}
\hline Sample ID & $\begin{array}{l}\text { Loading Time } \\
\text { (min) }\end{array}$ & $\begin{array}{c}\mathrm{Cs} \\
(\mathrm{mg} / \mathrm{kg})\end{array}$ & $\begin{array}{c}\mathrm{Al} \\
(\mathrm{mg} / \mathrm{kg})\end{array}$ & $\begin{array}{c}\mathrm{Na} \\
(\mathrm{mg} / \mathrm{kg})\end{array}$ & $\begin{array}{c}\mathrm{K} \\
(\mathrm{mg} / \mathrm{kg})\end{array}$ & $\begin{array}{l}\text { OH-Free } \\
\text { (meq/mL) }\end{array}$ & $\begin{array}{l}\text { OH-Total } \\
(\mathrm{meq} / \mathrm{mL})\end{array}$ & $\begin{array}{c}\mathrm{Cl} \\
(\mathrm{mg} / \mathrm{kg})\end{array}$ & $\begin{array}{c}\mathrm{NO}_{3} \\
(\mathrm{mg} / \mathrm{kg})\end{array}$ & $\begin{array}{c}\mathrm{NO}_{2} \\
(\mathrm{mg} / \mathrm{kg})\end{array}$ & $\begin{array}{c}\mathrm{PO}_{4} \\
(\mathrm{mg} / \mathrm{kg})\end{array}$ & $\begin{array}{c}\mathrm{SO}_{4} \\
(\mathrm{mg} / \mathrm{kg})\end{array}$ & $\begin{array}{c}\mathrm{C}_{2} \mathrm{O}_{4} \\
(\mathrm{mg} / \mathrm{kg})\end{array}$ & $\begin{array}{c}\text { TIC } \\
\text { (mg/kg) }\end{array}$ & $\begin{array}{c}\text { TOC } \\
(\mathrm{mg} / \mathrm{kg})\end{array}$ \\
\hline B5-LD-00 & 0 & 5.13 & 3640 & 91400 & 1050 & 1.49 & 2.17 & $<32.5$ & 23800 & 9350 & 345 & 852 & 909 & 7980 & 338 \\
\hline B5-LD-06 & 6 & 4.07 & 3490 & 88600 & 984 & 1.43 & 2.08 & $<32.8$ & 22700 & 8920 & 313 & 832 & 895 & 7400 & 327 \\
\hline B5-LD-12 & 12 & 3.43 & 3430 & 89100 & 985 & 1.43 & 2.09 & $<32.9$ & 22800 & 8910 & 307 & 844 & 919 & 7515 & 328 \\
\hline B5-LD-18 & 18 & 3.02 & 3470 & 89000 & 973 & 1.45 & 2.12 & $<32.8$ & 23000 & 9030 & 348 & 808 & 919 & 8030 & 328 \\
\hline B5-LD-24 & 24 & 2.61 & 3330 & 88800 & 977 & 1.43 & 2.07 & $<32.7$ & 22300 & 8800 & 313 & 839 & 922 & 7620 & 318 \\
\hline B5-LD-48 & 48 & 1.78 & 3430 & 89600 & 1010 & 1.44 & 2.09 & $<32.8$ & 22700 & 8870 & 304 & 814 & 850 & 7695 & 338 \\
\hline B5-LD-60 & 60 & 1.55 & 3430 & 88000 & 981 & 1.44 & 2.10 & $<32.9$ & 23300 & 9040 & 341 & 843 & 907 & 7475 & 329 \\
\hline B5-LD-80 & 80 & 1.32 & 3990 & 89100 & 977 & 1.44 & 2.10 & $<32.6$ & 23200 & 9060 & 311 & 821 & 873 & 8005 & 338 \\
\hline B5-LD-120 & 120 & 1.06 & 3440 & 88700 & 969 & 1.45 & 2.11 & $<32.9$ & 22700 & 8830 & 304 & 811 & 859 & 7730 & 323 \\
\hline B5-LD-180 & 180 & 0.876 & 3400 & 87300 & 962 & 1.44 & 2.09 & $<33.0$ & 22200 & 8900 & 284 & 827 & 884 & 7535 & 320 \\
\hline B5-LD-240 & 240 & 0.813 & 3450 & 89200 & 993 & 1.44 & 2.09 & $<32.8$ & 22500 & 8870 & 318 & 837 & 875 & 7840 & 336 \\
\hline B5-FD-CP & $\begin{array}{c}\text { Feed } \\
\text { Displacement }\end{array}$ & 0.504 & 2000 & 54600 & 584 & 0.879 & 1.24 & $<35.3$ & 13400 & 5360 & 230 & 482 & 533 & 4125 & 195 \\
\hline Target & -- & 4.86 & 3280 & 93200 & 951 & 1.20 & 2.01 & 0 & 23100 & 9430 & 326 & 856 & 1210 & 7960 & 408 \\
\hline
\end{tabular}


Table B.13. Column C1 Test Analytical Data $\left(\mathrm{T}=30^{\circ} \mathrm{C}\right.$, Flow rate $\left.=10.62 \mathrm{~mL} / \mathrm{min}\right)$

\begin{tabular}{|c|c|c|c|c|c|c|c|c|c|c|c|c|c|c|c|}
\hline Sample ID & $\begin{array}{l}\text { Loading Time } \\
\text { (min) }\end{array}$ & $\begin{array}{c}\mathrm{Cs} \\
(\mathrm{mg} / \mathrm{kg})\end{array}$ & $\begin{array}{c}\mathrm{Al} \\
(\mathrm{mg} / \mathrm{kg})\end{array}$ & $\begin{array}{c}\mathrm{Na} \\
(\mathrm{mg} / \mathrm{kg})\end{array}$ & $\begin{array}{c}\mathrm{K} \\
(\mathrm{mg} / \mathrm{kg})\end{array}$ & $\begin{array}{c}\text { OH-Free } \\
(\mathrm{meq} / \mathrm{mL})\end{array}$ & $\begin{array}{l}\text { OH-Total } \\
\text { (meq/mL) }\end{array}$ & $\begin{array}{c}\mathrm{Cl} \\
(\mathrm{mg} / \mathrm{kg})\end{array}$ & $\begin{array}{c}\mathrm{NO}_{3} \\
(\mathrm{mg} / \mathrm{kg})\end{array}$ & $\begin{array}{c}\mathrm{NO}_{2} \\
(\mathrm{mg} / \mathrm{kg})\end{array}$ & $\begin{array}{c}\mathrm{PO}_{4} \\
(\mathrm{mg} / \mathrm{kg})\end{array}$ & $\begin{array}{c}\mathrm{SO}_{4} \\
(\mathrm{mg} / \mathrm{kg})\end{array}$ & $\begin{array}{c}\mathrm{C}_{2} \mathrm{O}_{4} \\
(\mathrm{mg} / \mathrm{kg})\end{array}$ & $\begin{array}{c}\text { TIC } \\
(\mathrm{mg} / \mathrm{kg})\end{array}$ & $\begin{array}{c}\text { TOC } \\
(\mathrm{mg} / \mathrm{kg})\end{array}$ \\
\hline C1-LD-00 & 0 & 4.94 & 3360 & 92600 & 1080 & 1.48 & 2.15 & $<32.8$ & 23700 & 9240 & 341 & 844 & 861 & 8045 & 301 \\
\hline C1-LD-06 & 6 & 4.05 & 3040 & 88100 & 979 & 1.44 & 2.09 & $<33.1$ & 22900 & 8890 & 359 & 809 & 800 & 7550 & 288 \\
\hline C1-LD-12 & 12 & 3.63 & 3190 & 89600 & 1010 & 1.42 & 2.07 & $<32.9$ & 22500 & 8810 & 310 & 816 & 789 & 7750 & 286 \\
\hline C1-LD-18 & 18 & 3.25 & 3170 & 89000 & 1020 & 1.43 & 2.08 & $<32.8$ & 22800 & 8890 & 342 & 802 & 806 & 7575 & 288 \\
\hline C1-LD-24 & 24 & 2.94 & 3260 & 89800 & 1010 & 1.44 & 2.10 & $<33.0$ & 22700 & 8860 & 282 & 808 & 776 & 7750 & 288 \\
\hline C1-LD-36 & 36 & 2.47 & 3180 & 88500 & 999 & 1.43 & 2.09 & $<33.1$ & 22000 & 8840 & 342 & 809 & 808 & 7625 & 286 \\
\hline C1-LD-48 & 48 & 2.17 & 3090 & 89100 & 1000 & 1.42 & 2.08 & $<33.1$ & 22700 & 8820 & 338 & 823 & 759 & 7445 & 285 \\
\hline C1-LD-60 & 60 & 1.92 & 3160 & 89900 & 1030 & 1.42 & 2.07 & $<32.8$ & 22600 & 8840 & 330 & 812 & 741 & 7650 & 287 \\
\hline C1-LD-80 & 80 & 1.63 & 3180 & 89300 & 1010 & 1.44 & 2.11 & $<33.0$ & 22500 & 8720 & 297 & 845 & 852 & 7695 & 287 \\
\hline C1-LD-120 & 120 & 1.25 & 3190 & 90200 & 1020 & 1.42 & 2.09 & $<32.9$ & 22700 & 8840 & 343 & 831 & 801 & 7470 & 284 \\
\hline C1-LD-180 & 180 & 0.933 & 3070 & 89000 & 1010 & 1.43 & 2.08 & $<32.8$ & 23000 & 8960 & 319 & 789 & 773 & 7445 & 287 \\
\hline C1-LD-240 & 240 & 0.822 & 3230 & 90100 & 1030 & 1.42 & 2.07 & $<32.8$ & 22700 & 8830 & 299 & 850 & 797 & 7610 & 288 \\
\hline C1-LD-600 & 600 & 0.583 & 3190 & 89000 & 1010 & 1.41 & 2.06 & $<32.9$ & 22500 & 8770 & 304 & 831 & 783 & 7750 & 285 \\
\hline C1-FD-CP & $\begin{array}{c}\text { Feed } \\
\text { Displacement }\end{array}$ & 0.370 & 1860 & 55100 & 612 & 0.868 & 1.23 & $<47.9$ & 13400 & 5300 & 192 & 470 & 505 & 4125 & 208 \\
\hline C1-EL-CP & Elution & 15.2 & 4.29 & 1260 & 64.6 & $<0.05$ & $<0.05$ & $<40.2$ & 3340 & $<40.2$ & $<40.2$ & $<40.2$ & $<40.2$ & $<25.0$ & $<10.0$ \\
\hline Target & -- & 4.86 & 3280 & 93200 & 951 & 1.20 & 2.01 & 0 & 23100 & 9430 & 326 & 856 & 1210 & 7960 & 408 \\
\hline
\end{tabular}


Table B.14. Column C2 Test Analytical Data $\left(\mathrm{T}=30^{\circ} \mathrm{C}\right.$, Flow rate $\left.=14.16 \mathrm{~mL} / \mathrm{min}\right)$

\begin{tabular}{|c|c|c|c|c|c|c|c|c|c|c|c|c|c|c|c|}
\hline Sample ID & $\begin{array}{l}\text { Loading Time } \\
\text { (min) }\end{array}$ & $\begin{array}{c}\mathrm{Cs} \\
(\mathrm{mg} / \mathrm{kg})\end{array}$ & $\begin{array}{c}\mathrm{Al} \\
(\mathrm{mg} / \mathrm{kg})\end{array}$ & $\begin{array}{c}\mathrm{Na} \\
(\mathrm{mg} / \mathrm{kg})\end{array}$ & $\begin{array}{c}\mathrm{K} \\
(\mathrm{mg} / \mathrm{kg})\end{array}$ & $\begin{array}{l}\text { OH-Free } \\
\text { (meq/mL) }\end{array}$ & $\begin{array}{l}\text { OH-Total } \\
\text { (meq/mL) }\end{array}$ & $\begin{array}{c}\mathrm{Cl} \\
(\mathrm{mg} / \mathrm{kg})\end{array}$ & $\begin{array}{c}\mathrm{NO}_{3} \\
(\mathrm{mg} / \mathrm{kg})\end{array}$ & $\begin{array}{c}\mathrm{NO}_{2} \\
(\mathrm{mg} / \mathrm{kg})\end{array}$ & $\begin{array}{c}\mathrm{PO}_{4} \\
(\mathrm{mg} / \mathrm{kg})\end{array}$ & $\begin{array}{c}\mathrm{SO}_{4} \\
(\mathrm{mg} / \mathrm{kg})\end{array}$ & $\begin{array}{c}\mathrm{C}_{2} \mathrm{O}_{4} \\
(\mathrm{mg} / \mathrm{kg})\end{array}$ & $\begin{array}{c}\text { TIC } \\
(\mathrm{mg} / \mathrm{kg})\end{array}$ & $\begin{array}{c}\text { TOC } \\
(\mathrm{mg} / \mathrm{kg})\end{array}$ \\
\hline C2-LD-00 & 0 & 5.07 & 3470 & 92300 & 1110 & 1.48 & 2.17 & $<32.5$ & 23500 & 9150 & 306 & 877 & 856 & 7995 & 292 \\
\hline C2-LD-06 & 6 & 4.10 & 3290 & 90900 & 1040 & 1.43 & 2.09 & $<32.8$ & 22800 & 8820 & 303 & 795 & 812 & 7735 & 290 \\
\hline C2-LD-12 & 12 & 3.53 & 3310 & 90800 & 1040 & 1.43 & 2.10 & $<32.8$ & 22800 & 8840 & 315 & 821 & 827 & 7815 & 287 \\
\hline C2-LD-18 & 18 & 3.17 & 3470 & 92200 & 1050 & 1.51 & 2.24 & $<32.6$ & 24000 & 9220 & 347 & 842 & 811 & 8430 & 308 \\
\hline C2-LD-24 & 24 & 2.83 & 3330 & 91100 & 1040 & 1.44 & 2.10 & $<32.9$ & 23000 & 8910 & 282 & 827 & 796 & 7905 & 286 \\
\hline C2-LD-48 & 48 & 1.97 & 3350 & 89900 & 1030 & 1.44 & 2.11 & $<32.9$ & 22800 & 8820 & 315 & 814 & 757 & 7885 & 291 \\
\hline C2-LD-60 & 60 & 1.73 & 3380 & 89600 & 1020 & 1.44 & 2.08 & $<32.8$ & 23000 & 8890 & 293 & 806 & 754 & 7555 & 286 \\
\hline C2-LD-80 & 80 & 1.44 & 3300 & 89300 & 1020 & 1.44 & 2.10 & $<32.6$ & 22900 & 8890 & 271 & 825 & 796 & 7755 & 284 \\
\hline C2-LD-120 & 120 & 1.09 & 3290 & 88800 & 1000 & 1.42 & 2.08 & $<34.0$ & 22700 & 8900 & 284 & 823 & 762 & 7855 & 287 \\
\hline C2-LD-180 & 180 & 0.874 & 3370 & 89800 & 1020 & 1.44 & 2.08 & $<32.9$ & 22800 & 8800 & 322 & 817 & 789 & 8005 & 293 \\
\hline C2-LD-240 & 240 & 0.768 & 3350 & 89700 & 1020 & 1.42 & 2.07 & $<32.8$ & 22800 & 8930 & 290 & 815 & 775 & 7875 & 287 \\
\hline C2-FD-CP & $\begin{array}{c}\text { Feed } \\
\text { Displacement }\end{array}$ & 0.370 & 1970 & 57000 & 610 & 0.879 & 1.24 & 42.8 & 13400 & 5230 & 179 & 492 & 591 & 4195 & 220 \\
\hline C2-EL-CP & Elution & 13.8 & 6.72 & 1230 & 63.6 & $<0.05$ & $<0.05$ & $<40.2$ & 3230 & $<40.2$ & $<40.2$ & $<40.2$ & $<40.2$ & $<25.0$ & 13.7 \\
\hline Target & -- & 4.86 & 3280 & 93200 & 951 & 1.20 & 2.01 & 0 & 23100 & 9430 & 326 & 856 & 1210 & 7960 & 408 \\
\hline
\end{tabular}


Table B.15. Column C3 Test Analytical Data $\left(T=30^{\circ} \mathrm{C}\right.$, Flow rate $\left.=7.08 \mathrm{~mL} / \mathrm{min}\right)$

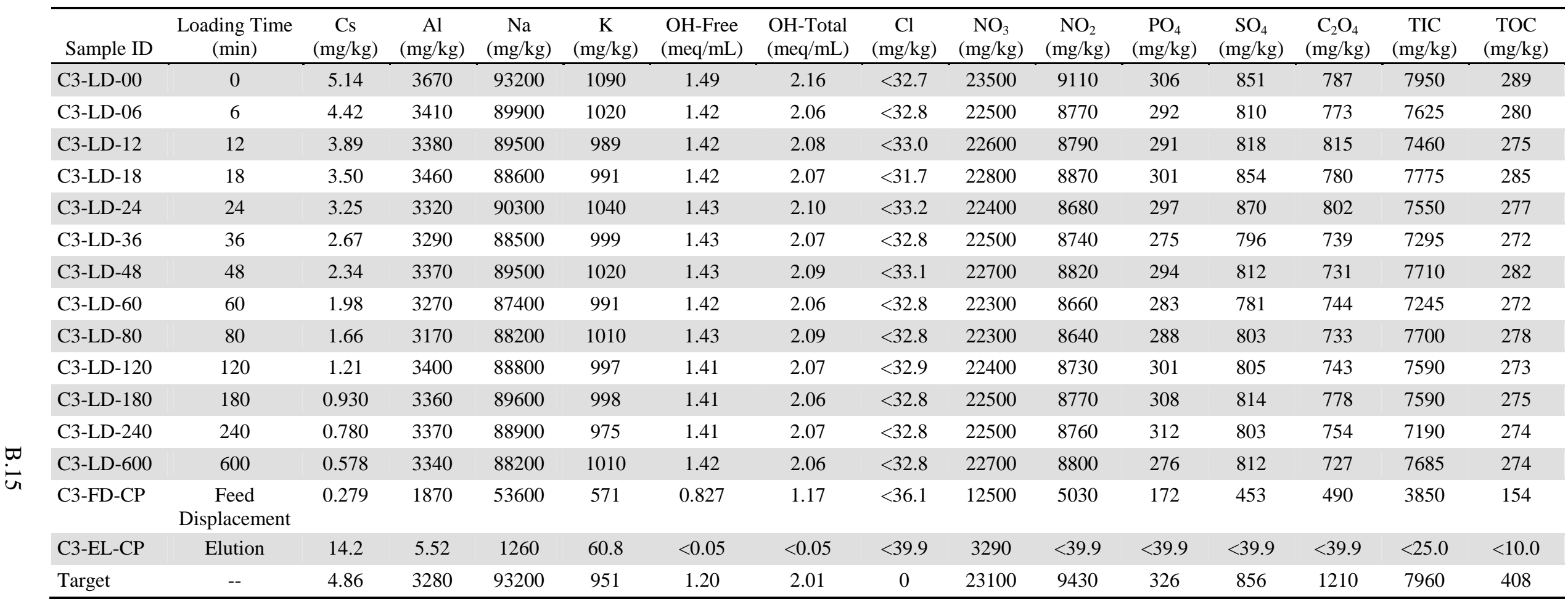


Table B.16. Column C4 Test Analytical Data $\left(\mathrm{T}=30^{\circ} \mathrm{C}\right.$, Flow rate $\left.=10.62 \mathrm{~mL} / \mathrm{min}\right)$

\begin{tabular}{|c|c|c|c|c|c|c|c|c|c|c|c|c|c|c|c|}
\hline Sample ID & $\begin{array}{l}\text { Loading Time } \\
\text { (min) }\end{array}$ & $\begin{array}{c}\mathrm{Cs} \\
(\mathrm{mg} / \mathrm{kg})\end{array}$ & $\begin{array}{c}\mathrm{Al} \\
(\mathrm{mg} / \mathrm{kg})\end{array}$ & $\begin{array}{c}\mathrm{Na} \\
(\mathrm{mg} / \mathrm{kg})\end{array}$ & $\begin{array}{c}\mathrm{K} \\
(\mathrm{mg} / \mathrm{kg})\end{array}$ & $\begin{array}{c}\text { OH-Free } \\
(\mathrm{meq} / \mathrm{mL})\end{array}$ & $\begin{array}{l}\text { OH-Total } \\
(\mathrm{meq} / \mathrm{mL})\end{array}$ & $\begin{array}{c}\mathrm{Cl} \\
(\mathrm{mg} / \mathrm{kg})\end{array}$ & $\begin{array}{c}\mathrm{NO}_{3} \\
(\mathrm{mg} / \mathrm{kg})\end{array}$ & $\begin{array}{c}\mathrm{NO}_{2} \\
(\mathrm{mg} / \mathrm{kg})\end{array}$ & $\begin{array}{c}\mathrm{PO}_{4} \\
(\mathrm{mg} / \mathrm{kg})\end{array}$ & $\begin{array}{c}\mathrm{SO}_{4} \\
(\mathrm{mg} / \mathrm{kg})\end{array}$ & $\begin{array}{c}\mathrm{C}_{2} \mathrm{O}_{4} \\
(\mathrm{mg} / \mathrm{kg})\end{array}$ & $\begin{array}{c}\text { TIC } \\
(\mathrm{mg} / \mathrm{kg})\end{array}$ & $\begin{array}{c}\text { TOC } \\
(\mathrm{mg} / \mathrm{kg})\end{array}$ \\
\hline C4-LD-00 & 0 & 5.01 & 3440 & 94700 & 1120 & 1.51 & 2.20 & $<32.4$ & 24500 & 9510 & 322 & 864 & 796 & 8080 & 291 \\
\hline C4-LD-06 & 6 & 4.12 & 3260 & 90500 & 1050 & 1.44 & 2.10 & $<32.8$ & 23300 & 9050 & 294 & 833 & 763 & 7520 & 303 \\
\hline C4-LD-12 & 12 & 3.68 & 3260 & 91300 & 1060 & 1.43 & 2.08 & $<32.8$ & 23100 & 8970 & 290 & 808 & 745 & 7895 & 280 \\
\hline C4-LD-18 & 18 & 3.23 & 3250 & 89900 & 1040 & 1.44 & 2.10 & $<32.9$ & 23400 & 9080 & 287 & 841 & 750 & 7960 & 358 \\
\hline C4-LD-24 & 24 & 2.92 & 3310 & 91800 & 1080 & 1.43 & 2.11 & $<32.7$ & 23400 & 9050 & 312 & 835 & 755 & 7980 & 279 \\
\hline C4-LD-48 & 48 & 2.20 & 3350 & 95000 & 1070 & 1.51 & 2.23 & $<32.7$ & 24200 & 9330 & 284 & 857 & 762 & 8020 & 295 \\
\hline C4-LD-60 & 60 & 1.83 & 3200 & 90100 & 1040 & 1.45 & 2.10 & $<33.0$ & 23300 & 9040 & 323 & 843 & 819 & 7565 & 281 \\
\hline C4-LD-80 & 80 & 1.50 & 3260 & 91500 & 1070 & 1.47 & 2.16 & $<34.4$ & 24100 & 9320 & 329 & 892 & 848 & 8315 & 452 \\
\hline C4-LD-120 & 120 & 1.07 & 3270 & 90800 & 1040 & 1.42 & 2.08 & $<33.2$ & 23200 & 9000 & 292 & 831 & 750 & 8100 & 282 \\
\hline C4-LD-180 & 180 & 0.822 & 3290 & 90600 & 1030 & 1.43 & 2.10 & $<32.8$ & 23200 & 9010 & 279 & 812 & 731 & 7890 & 278 \\
\hline C4-LD-240 & 240 & 0.710 & 3240 & 89700 & 1010 & 1.41 & 2.05 & $<32.9$ & 22800 & 8780 & 284 & 816 & 746 & 7910 & 273 \\
\hline C4-FD-CP & $\begin{array}{c}\text { Feed } \\
\text { Displacement }\end{array}$ & 0.366 & 2050 & 57800 & 639 & 0.898 & 1.28 & 43.3 & 14500 & 5690 & 202 & 523 & 479 & 4385 & 188 \\
\hline Target & -- & 4.86 & 3280 & 93200 & 951 & 1.20 & 2.01 & 0 & 23100 & 9430 & 326 & 856 & 1210 & 7960 & 408 \\
\hline
\end{tabular}


Table B.17. Column C4B Test Analytical Data $\left(T=50^{\circ} \mathrm{C}\right.$, Flow rate $\left.=0.08 \mathrm{~mL} / \mathrm{min}\right)$

\begin{tabular}{|c|c|c|c|c|c|c|c|c|c|c|c|c|c|c|c|}
\hline Sample ID & $\begin{array}{l}\text { Loading Time } \\
\text { (hr) }\end{array}$ & $\begin{array}{c}\mathrm{Cs} \\
(\mathrm{mg} / \mathrm{kg})\end{array}$ & $\begin{array}{c}\mathrm{Al} \\
(\mathrm{mg} / \mathrm{kg})\end{array}$ & $\begin{array}{c}\mathrm{Na} \\
(\mathrm{mg} / \mathrm{kg})\end{array}$ & $\begin{array}{c}\mathrm{K} \\
(\mathrm{mg} / \mathrm{kg})\end{array}$ & $\begin{array}{c}\text { OH-Free } \\
(\mathrm{meq} / \mathrm{mL})\end{array}$ & $\begin{array}{l}\text { OH-Total } \\
\text { (meq/mL) }\end{array}$ & $\begin{array}{c}\mathrm{Cl} \\
(\mathrm{mg} / \mathrm{kg})\end{array}$ & $\begin{array}{c}\mathrm{NO}_{3} \\
(\mathrm{mg} / \mathrm{kg})\end{array}$ & $\begin{array}{c}\mathrm{NO}_{2} \\
(\mathrm{mg} / \mathrm{kg})\end{array}$ & $\begin{array}{c}\mathrm{PO}_{4} \\
(\mathrm{mg} / \mathrm{kg})\end{array}$ & $\begin{array}{c}\mathrm{SO}_{4} \\
(\mathrm{mg} / \mathrm{kg})\end{array}$ & $\begin{array}{c}\mathrm{C}_{2} \mathrm{O}_{4} \\
(\mathrm{mg} / \mathrm{kg})\end{array}$ & $\begin{array}{c}\text { TIC } \\
(\mathrm{mg} / \mathrm{kg})\end{array}$ & $\begin{array}{c}\text { TOC } \\
(\mathrm{mg} / \mathrm{kg})\end{array}$ \\
\hline C4B-LD-00 & 0 & 5.10 & 3530 & 98400 & 1160 & 1.49 & 2.17 & $<32.8$ & 24000 & 9300 & 328 & 878 & 820 & 7840 & 285 \\
\hline C4B-LD-04 & 4 & 5.52 & 3980 & 107000 & 1100 & 1.32 & 1.87 & $<32.7$ & 25900 & 10000 & 329 & 951 & 836 & 7190 & 294 \\
\hline C4B-LD-08 & 8 & 4.09 & 3220 & 89000 & 1050 & 1.41 & 2.08 & $<32.4$ & 23300 & 9070 & 304 & 835 & 778 & 8040 & 278 \\
\hline C4B-LD-12 & 12 & 3.82 & 3260 & 90300 & 1060 & 1.41 & 2.07 & $<32.8$ & 23400 & 9090 & 297 & 822 & 774 & 7865 & 277 \\
\hline C4B-LD-24 & 24 & 3.11 & 3300 & 91900 & 1080 & 1.43 & 2.09 & $<32.7$ & 23400 & 9050 & 305 & 829 & 761 & 7875 & 277 \\
\hline C4B-LD-72 & 72 & 2.19 & 3340 & 91900 & 1090 & 1.46 & 2.14 & 230 & 23800 & 9250 & 319 & 878 & 785 & 8350 & 285 \\
\hline C4B-LD-120 & 120 & 2.23 & 3410 & 95000 & 1130 & 1.45 & 2.13 & $<32.6$ & 24000 & 9310 & 314 & 862 & 806 & 8070 & 297 \\
\hline C4B-LD-168 & 168 & 2.44 & 3740 & 104000 & 1110 & 1.32 & 1.95 & $<43.4$ & 26300 & 10300 & 348 & 952 & 853 & 7355 & 302 \\
\hline C4B-LD-336 & 336 & 2.43 & 3110 & 87300 & 1090 & 1.50 & 2.19 & $<33.3$ & 24700 & 9210 & 336 & 866 & 849 & 8205 & 351 \\
\hline C4B-LD-504 & 504 & 2.55 & 3190 & 90000 & 1130 & 1.58 & 2.35 & $<33.2$ & 26000 & 9770 & 369 & 919 & 913 & 9215 & 392 \\
\hline C4B-FD-CP & $\begin{array}{c}\text { Feed } \\
\text { Displacement }\end{array}$ & 1.87 & 2280 & 71400 & 809 & 1.13 & 1.59 & $<39.1$ & 17800 & 6680 & 256 & 675 & 631 & 6050 & 370 \\
\hline C4B-EL-CP & Elution & 18.8 & 93.4 & 1240 & 38.2 & $<0.05$ & $<0.05$ & $<40.0$ & 3220 & $<40.0$ & $<40.0$ & $<40.0$ & $<40.0$ & $<25.0$ & $<10.0$ \\
\hline Target & -- & 4.86 & 3280 & 93200 & 951 & 1.20 & 2.01 & 0 & 23100 & 9430 & 326 & 856 & 1210 & 7960 & 408 \\
\hline
\end{tabular}


Table B.18. Column C5 Test Analytical Data $\left(\mathrm{T}=30^{\circ} \mathrm{C}\right.$, Flow rate $\left.=10.62 \mathrm{~mL} / \mathrm{min}\right)$

\begin{tabular}{|c|c|c|c|c|c|c|c|c|c|c|c|c|c|c|c|}
\hline Sample ID & $\begin{array}{l}\text { Loading Time } \\
\text { (min) }\end{array}$ & $\begin{array}{c}\mathrm{Cs} \\
(\mathrm{mg} / \mathrm{kg})\end{array}$ & $\begin{array}{c}\mathrm{Al} \\
(\mathrm{mg} / \mathrm{kg})\end{array}$ & $\begin{array}{c}\mathrm{Na} \\
(\mathrm{mg} / \mathrm{kg})\end{array}$ & $\begin{array}{c}\mathrm{K} \\
(\mathrm{mg} / \mathrm{kg})\end{array}$ & $\begin{array}{l}\text { OH-Free } \\
\text { (meq/mL) }\end{array}$ & $\begin{array}{l}\text { OH-Total } \\
(\mathrm{meq} / \mathrm{mL})\end{array}$ & $\begin{array}{c}\mathrm{Cl} \\
(\mathrm{mg} / \mathrm{kg})\end{array}$ & $\begin{array}{c}\mathrm{NO}_{3} \\
(\mathrm{mg} / \mathrm{kg})\end{array}$ & $\begin{array}{c}\mathrm{NO}_{2} \\
(\mathrm{mg} / \mathrm{kg})\end{array}$ & $\begin{array}{c}\mathrm{PO}_{4} \\
(\mathrm{mg} / \mathrm{kg})\end{array}$ & $\begin{array}{c}\mathrm{SO}_{4} \\
(\mathrm{mg} / \mathrm{kg})\end{array}$ & $\begin{array}{c}\mathrm{C}_{2} \mathrm{O}_{4} \\
(\mathrm{mg} / \mathrm{kg})\end{array}$ & $\begin{array}{c}\text { TIC } \\
\text { (mg/kg) }\end{array}$ & $\begin{array}{c}\text { TOC } \\
(\mathrm{mg} / \mathrm{kg})\end{array}$ \\
\hline C5-LD-00 & 0 & 5.08 & 3040 & 90500 & 1070 & 1.46 & 2.15 & $<32.5$ & 23900 & 8900 & 326 & 847 & 956 & 7970 & 331 \\
\hline C5-LD-06 & 6 & 4.46 & 2980 & 89600 & 1030 & 1.44 & 2.11 & $<32.6$ & 23300 & 8720 & 311 & 814 & 1160 & 7750 & 400 \\
\hline C5-LD-12 & 12 & 3.92 & 2960 & 89400 & 1010 & 1.44 & 2.09 & $<32.5$ & 23200 & 8730 & 318 & 827 & 1180 & 7805 & 397 \\
\hline C5-LD-18 & 18 & 3.72 & 2990 & 89400 & 1030 & 1.43 & 2.07 & $<32.9$ & 23300 & 8710 & 303 & 818 & 1150 & 7735 & 395 \\
\hline C5-LD-24 & 24 & 3.43 & 2970 & 85000 & 1040 & 1.44 & 2.11 & $<32.9$ & 23300 & 8760 & 299 & 837 & 1170 & 7715 & 398 \\
\hline C5-LD-48 & 48 & 2.72 & 3010 & 89100 & 1030 & 1.43 & 2.09 & $<33.0$ & 23300 & 8750 & 296 & 825 & 1160 & 7770 & 402 \\
\hline C5-LD-60 & 60 & 2.46 & 2940 & 89200 & 1020 & 1.44 & 2.10 & $<32.9$ & 23300 & 8760 & 308 & 823 & 1150 & 7795 & 395 \\
\hline C5-LD-80 & 80 & 2.14 & 2990 & 79000 & 1010 & 1.44 & 2.10 & $<32.8$ & 23100 & 8660 & 281 & 832 & 1140 & 7840 & 391 \\
\hline C5-LD-120 & 120 & 1.80 & 2980 & 88700 & 1020 & 1.44 & 2.09 & $<33.2$ & 23800 & 8910 & 324 & 839 & 1170 & 7830 & 403 \\
\hline C5-LD-180 & 180 & 1.52 & 2980 & 87500 & 1040 & 1.44 & 2.09 & $<32.8$ & 23200 & 8710 & 337 & 809 & 1170 & 7770 & 399 \\
\hline C5-LD-240 & 240 & 1.35 & 2980 & 85500 & 1020 & 1.44 & 2.10 & $<32.9$ & 23400 & 8770 & 307 & 815 & 1160 & 7650 & 404 \\
\hline C5-FD-CP & $\begin{array}{c}\text { Feed } \\
\text { Displacement }\end{array}$ & 0.797 & 2020 & 56900 & 663 & 0.923 & 1.31 & $<35.6$ & 14600 & 5510 & 193 & 519 & 773 & 4605 & 273 \\
\hline Target & -- & 4.86 & 3280 & 93200 & 951 & 1.20 & 2.01 & 0 & 23100 & 9430 & 326 & 856 & 1210 & 7960 & 408 \\
\hline
\end{tabular}


Table B.19. Column D1 Test Analytical Data $\left(\mathrm{T}=25^{\circ} \mathrm{C}\right.$, Flow rate $\left.=10.62 \mathrm{~mL} / \mathrm{min}\right)$

\begin{tabular}{|c|c|c|c|c|c|c|c|c|c|c|c|c|c|c|c|}
\hline Sample ID & $\begin{array}{l}\text { Loading Time } \\
\text { (min) }\end{array}$ & $\begin{array}{c}\mathrm{Cs} \\
(\mathrm{mg} / \mathrm{kg})\end{array}$ & $\begin{array}{c}\mathrm{Al} \\
(\mathrm{mg} / \mathrm{kg})\end{array}$ & $\begin{array}{c}\mathrm{Na} \\
(\mathrm{mg} / \mathrm{kg})\end{array}$ & $\begin{array}{c}\mathrm{K} \\
(\mathrm{mg} / \mathrm{kg})\end{array}$ & $\begin{array}{c}\text { OH-Free } \\
(\mathrm{meq} / \mathrm{mL})\end{array}$ & $\begin{array}{l}\text { OH-Total } \\
\text { (meq/mL) }\end{array}$ & $\begin{array}{c}\mathrm{Cl} \\
(\mathrm{mg} / \mathrm{kg})\end{array}$ & $\begin{array}{c}\mathrm{NO}_{3} \\
(\mathrm{mg} / \mathrm{kg})\end{array}$ & $\begin{array}{c}\mathrm{NO}_{2} \\
(\mathrm{mg} / \mathrm{kg})\end{array}$ & $\begin{array}{c}\mathrm{PO}_{4} \\
(\mathrm{mg} / \mathrm{kg})\end{array}$ & $\begin{array}{c}\mathrm{SO}_{4} \\
(\mathrm{mg} / \mathrm{kg})\end{array}$ & $\begin{array}{c}\mathrm{C}_{2} \mathrm{O}_{4} \\
(\mathrm{mg} / \mathrm{kg})\end{array}$ & $\begin{array}{c}\text { TIC } \\
(\mathrm{mg} / \mathrm{kg})\end{array}$ & $\begin{array}{c}\text { TOC } \\
(\mathrm{mg} / \mathrm{kg})\end{array}$ \\
\hline D1-LD-00 & 0 & 4.97 & 3470 & 92200 & 1060 & 1.47 & 2.14 & $<32.8$ & 23500 & 9160 & 342 & 830 & 819 & 7745 & 295 \\
\hline D1-LD-06 & 6 & 4.28 & 3330 & 89700 & 1010 & 1.40 & 2.05 & $<32.8$ & 22500 & 8760 & 352 & 793 & 835 & 7555 & 302 \\
\hline D1-LD-12 & 12 & 3.64 & 3520 & 89900 & 1000 & 1.43 & 2.03 & $<32.8$ & 22400 & 8740 & 341 & 790 & 781 & 7410 & 284 \\
\hline D1-LD-18 & 18 & 3.29 & 3390 & 89200 & 1000 & 1.42 & 2.07 & $<32.9$ & 22700 & 8840 & 283 & 813 & 793 & 7715 & 277 \\
\hline D1-LD-24 & 24 & 2.99 & 3370 & 90200 & 994 & 1.42 & 2.08 & $<32.6$ & 22500 & 8780 & 304 & 841 & 809 & 7560 & 289 \\
\hline D1-LD-36 & 36 & 2.46 & 3430 & 89500 & 998 & 1.42 & 2.07 & $<32.6$ & 22800 & 8820 & 275 & 791 & 754 & 7485 & 282 \\
\hline D1-LD-48 & 48 & 2.13 & 3450 & 89400 & 997 & 1.42 & 2.06 & $<32.9$ & 22600 & 8790 & 350 & 840 & 768 & 7360 & 284 \\
\hline D1-LD-60 & 60 & 1.88 & 3510 & 89100 & 995 & 1.42 & 2.09 & $<32.9$ & 22600 & 8850 & 328 & 824 & 753 & 7635 & 287 \\
\hline D1-LD-80 & 80 & 1.57 & 3370 & 88700 & 985 & 1.44 & 2.08 & $<32.7$ & 22500 & 8720 & 293 & 826 & 784 & 7695 & 284 \\
\hline D1-LD-120 & 120 & 1.20 & 3340 & 90300 & 1010 & 1.43 & 2.09 & $<32.9$ & 22600 & 8870 & 300 & 813 & 779 & 7545 & 287 \\
\hline D1-LD-180 & 180 & 0.922 & 3470 & 89400 & 997 & 1.42 & 2.07 & $<32.8$ & 22700 & 8720 & 279 & 823 & 777 & 7465 & 285 \\
\hline D1-LD-240 & 240 & 0.791 & 3420 & 89200 & 988 & 1.42 & 2.07 & $<32.9$ & 22600 & 8820 & 332 & 818 & 798 & 7560 & 292 \\
\hline D1-LD-600 & 600 & 0.563 & 3480 & 90200 & 1000 & 1.42 & 2.06 & $<32.9$ & 22600 & 8830 & 291 & 801 & 752 & 7840 & 287 \\
\hline D1-FD-CP & $\begin{array}{c}\text { Feed } \\
\text { Displacement }\end{array}$ & 0.315 & 1950 & 53600 & 576 & 0.827 & 1.18 & $<36.5$ & 12700 & 5070 & 176 & 465 & 498 & 3940 & 172 \\
\hline D1-EL-CP & Elution & 15.8 & 7.16 & 1240 & 68.5 & $<0.05$ & $<0.05$ & $<39.9$ & 3410 & $<39.9$ & $<39.9$ & $<39.9$ & $<39.9$ & $<25.0$ & $<10.0$ \\
\hline Target & -- & 4.86 & 3280 & 93200 & 951 & 1.20 & 2.01 & 0 & 23100 & 9430 & 326 & 856 & 1210 & 7960 & 408 \\
\hline
\end{tabular}


Table B.20. Column D2 Test Analytical Data $\left(\mathrm{T}=25^{\circ} \mathrm{C}\right.$, Flow rate $\left.=14.16 \mathrm{~mL} / \mathrm{min}\right)$

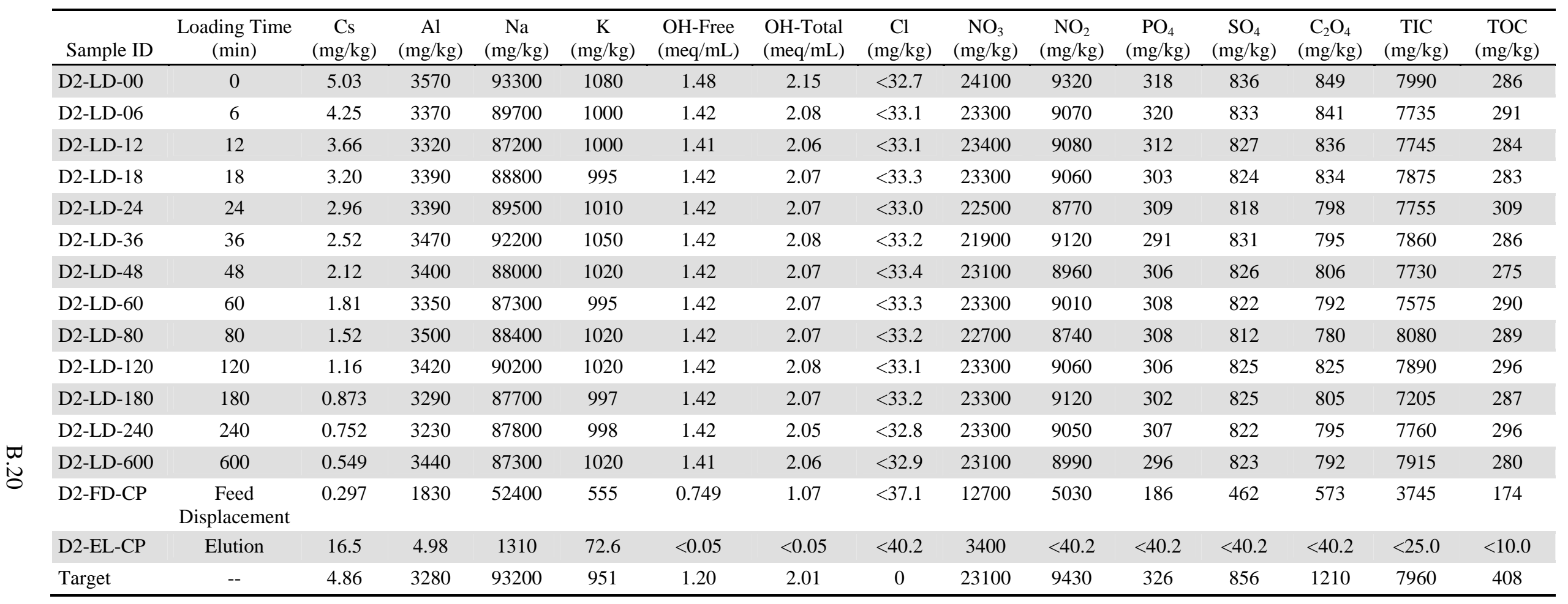


Table B.21. Column D3 Test Analytical Data $\left(\mathrm{T}=25^{\circ} \mathrm{C}\right.$, Flow rate $\left.=7.08 \mathrm{~mL} / \mathrm{min}\right)$

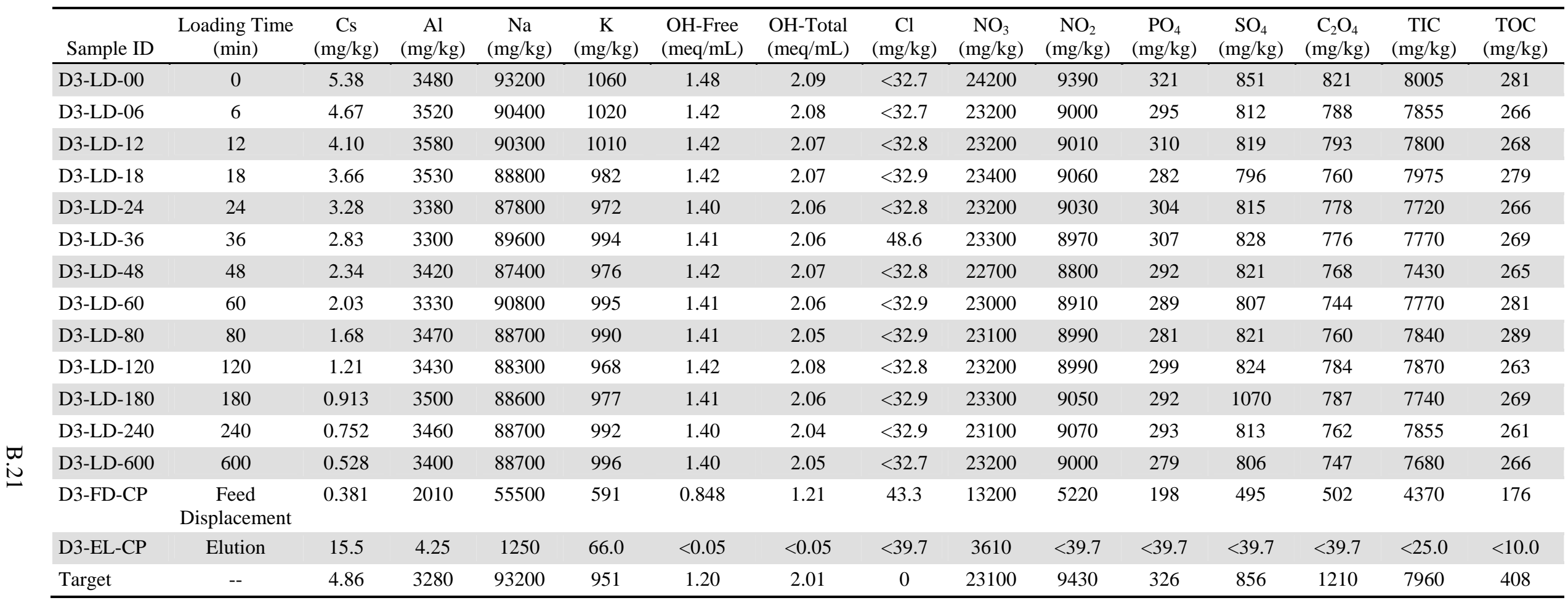


Table B.22. Column D4 Test Analytical Data $\left(\mathrm{T}=25^{\circ} \mathrm{C}\right.$, Flow rate $\left.=10.62 \mathrm{~mL} / \mathrm{min}\right)$

\begin{tabular}{|c|c|c|c|c|c|c|c|c|c|c|c|c|c|c|c|}
\hline Sample ID & $\begin{array}{l}\text { Loading Time } \\
(\mathrm{min})\end{array}$ & $\begin{array}{c}\mathrm{Cs} \\
(\mathrm{mg} / \mathrm{kg})\end{array}$ & $\begin{array}{c}\mathrm{Al} \\
(\mathrm{mg} / \mathrm{kg})\end{array}$ & $\begin{array}{c}\mathrm{Na} \\
(\mathrm{mg} / \mathrm{kg})\end{array}$ & $\begin{array}{c}\mathrm{K} \\
(\mathrm{mg} / \mathrm{kg})\end{array}$ & $\begin{array}{c}\text { OH-Free } \\
(\mathrm{meq} / \mathrm{mL})\end{array}$ & $\begin{array}{l}\text { OH-Total } \\
(\mathrm{meq} / \mathrm{mL})\end{array}$ & $\begin{array}{c}\mathrm{Cl} \\
(\mathrm{mg} / \mathrm{kg})\end{array}$ & $\begin{array}{c}\mathrm{NO}_{3} \\
(\mathrm{mg} / \mathrm{kg})\end{array}$ & $\begin{array}{c}\mathrm{NO}_{2} \\
(\mathrm{mg} / \mathrm{kg})\end{array}$ & $\begin{array}{c}\mathrm{PO}_{4} \\
(\mathrm{mg} / \mathrm{kg})\end{array}$ & $\begin{array}{c}\mathrm{SO}_{4} \\
(\mathrm{mg} / \mathrm{kg})\end{array}$ & $\begin{array}{c}\mathrm{C}_{2} \mathrm{O}_{4} \\
(\mathrm{mg} / \mathrm{kg})\end{array}$ & $\begin{array}{c}\text { TIC } \\
(\mathrm{mg} / \mathrm{kg})\end{array}$ & $\begin{array}{c}\text { TOC } \\
(\mathrm{mg} / \mathrm{kg})\end{array}$ \\
\hline D4-LD-00 & 0 & 5.03 & 3310 & 92100 & 1070 & 1.48 & 2.15 & $<32.4$ & 24200 & 9400 & 315 & 863 & 800 & 7590 & 289 \\
\hline D4-LD-06 & 6 & 4.09 & 3160 & 87900 & 1010 & 1.43 & 2.07 & $<33.1$ & 23100 & 8930 & 315 & 864 & 788 & 7700 & 288 \\
\hline D4-LD-12 & 12 & 3.62 & 3140 & 88200 & 1010 & 1.42 & 2.07 & $<33.1$ & 23200 & 8990 & 295 & 815 & 738 & 7650 & 273 \\
\hline D4-LD-18 & 18 & 3.29 & 3660 & 91100 & 1030 & 1.45 & 2.11 & $<49.5$ & 23000 & 8850 & 316 & 818 & 812 & 7635 & 290 \\
\hline D4-LD-24 & 24 & 2.86 & 3520 & 89200 & 1020 & 1.41 & 2.08 & $<49.4$ & 23000 & 8860 & 325 & 813 & 780 & 7700 & 275 \\
\hline D4-LD-48 & 48 & 2.02 & 3460 & 88300 & 1030 & 1.41 & 2.06 & $<50.3$ & 22900 & 8870 & 302 & 811 & 777 & 7710 & 279 \\
\hline D4-LD-60 & 60 & 1.76 & 3440 & 90100 & 1000 & 1.43 & 2.08 & $<49.4$ & 23000 & 8850 & 295 & 804 & 765 & 7700 & 281 \\
\hline D4-LD-80 & 80 & 1.43 & 3490 & 88300 & 1010 & 1.43 & 2.07 & $<52.7$ & 23000 & 8880 & 302 & 839 & 764 & 7705 & 281 \\
\hline D4-LD-120 & 120 & 1.08 & 3180 & 89500 & 1000 & 1.42 & 2.08 & $<32.8$ & 23300 & 9030 & 293 & 837 & 767 & 7705 & 284 \\
\hline D4-LD-180 & 180 & 0.826 & 3570 & 87600 & 998 & 1.42 & 2.07 & $<49.4$ & 22800 & 8830 & 306 & 834 & 785 & 7620 & 285 \\
\hline D4-LD-240 & 240 & 0.721 & 3490 & 88300 & 1000 & 1.41 & 2.07 & $<49.5$ & 22900 & 8880 & 311 & 821 & 787 & 7340 & 280 \\
\hline D4-FD-CP & $\begin{array}{c}\text { Feed } \\
\text { Displacement }\end{array}$ & 0.293 & 1860 & 58500 & 580 & 0.827 & 1.16 & $<37.0$ & 14000 & 5520 & 185 & 496 & 478 & 4135 & 166 \\
\hline Target & -- & 4.86 & 3280 & 93200 & 951 & 1.20 & 2.01 & 0 & 23100 & 9430 & 326 & 856 & 1210 & 7960 & 408 \\
\hline
\end{tabular}


Table B.23. Column D4B Test Analytical Data $\left(T=45^{\circ} \mathrm{C}\right.$, Flow rate $\left.=0.08 \mathrm{~mL} / \mathrm{min}\right)$

\begin{tabular}{|c|c|c|c|c|c|c|c|c|c|c|c|c|c|c|c|}
\hline Sample ID & $\begin{array}{c}\text { Loading Time } \\
\text { (hr) }\end{array}$ & $\begin{array}{c}\mathrm{Cs} \\
(\mathrm{mg} / \mathrm{kg})\end{array}$ & $\begin{array}{c}\mathrm{Al} \\
(\mathrm{mg} / \mathrm{kg})\end{array}$ & $\begin{array}{c}\mathrm{Na} \\
(\mathrm{mg} / \mathrm{kg})\end{array}$ & $\begin{array}{c}\mathrm{K} \\
(\mathrm{mg} / \mathrm{kg})\end{array}$ & $\begin{array}{c}\text { OH-Free } \\
(\mathrm{meq} / \mathrm{mL})\end{array}$ & $\begin{array}{l}\text { OH-Total } \\
\text { (meq/mL) }\end{array}$ & $\begin{array}{c}\mathrm{Cl} \\
(\mathrm{mg} / \mathrm{kg})\end{array}$ & $\begin{array}{c}\mathrm{NO}_{3} \\
(\mathrm{mg} / \mathrm{kg})\end{array}$ & $\begin{array}{c}\mathrm{NO}_{2} \\
(\mathrm{mg} / \mathrm{kg})\end{array}$ & $\begin{array}{c}\mathrm{PO}_{4} \\
(\mathrm{mg} / \mathrm{kg})\end{array}$ & $\begin{array}{c}\mathrm{SO}_{4} \\
(\mathrm{mg} / \mathrm{kg})\end{array}$ & $\begin{array}{c}\mathrm{C}_{2} \mathrm{O}_{4} \\
(\mathrm{mg} / \mathrm{kg})\end{array}$ & $\begin{array}{c}\text { TIC } \\
(\mathrm{mg} / \mathrm{kg})\end{array}$ & $\begin{array}{c}\text { TOC } \\
(\mathrm{mg} / \mathrm{kg})\end{array}$ \\
\hline D4B-LD-00 & 0 & 5.07 & 3300 & 93300 & 1100 & 1.51 & 2.20 & $<32.6$ & 24600 & 9480 & 327 & 846 & 807 & 8200 & 304 \\
\hline D4B-LD-04 & 4 & 4.69 & 3250 & 91400 & 1070 & 1.42 & 2.09 & $<32.8$ & 23600 & 9100 & 312 & 860 & 782 & 7745 & 276 \\
\hline D4B-LD-08 & 8 & 4.17 & 3180 & 89900 & 1040 & 1.42 & 2.05 & $<32.7$ & 23600 & 9160 & 316 & 848 & 784 & 7735 & 277 \\
\hline D4B-LD-12 & 12 & 3.95 & 3260 & 92400 & 1090 & 1.43 & 2.09 & $<32.9$ & 23600 & 9130 & 318 & 849 & 785 & 7625 & 280 \\
\hline D4B-LD-24 & 24 & 2.98 & 3190 & 90400 & 1050 & 1.42 & 2.09 & $<32.5$ & 23400 & 9110 & 307 & 850 & 775 & 7815 & 280 \\
\hline D4B-LD-72 & 72 & 1.90 & 3190 & 93400 & 1110 & 1.42 & 2.08 & $<32.6$ & 23200 & 9000 & 300 & 865 & 798 & 7960 & 285 \\
\hline D4B-LD-120 & 120 & 3.79 & 3220 & 90900 & 1060 & 1.46 & 2.13 & 36.9 & 23900 & 9280 & 319 & 878 & 792 & 7990 & 294 \\
\hline D4B-LD-168 & 168 & 2.04 & 3310 & 92300 & 1100 & 1.48 & 2.17 & $<32.7$ & 24400 & 9440 & 327 & 871 & 795 & 8025 & 305 \\
\hline D4B-LD-336 & 336 & 2.02 & 3450 & 89600 & 1040 & 1.48 & 2.18 & $<33.8$ & 24400 & 8890 & 329 & 852 & 823 & 8320 & 336 \\
\hline D4B-LD-504 & 504 & 2.19 & 3760 & 90100 & 1130 & 1.57 & 2.34 & $<32.8$ & 25600 & 9460 & 343 & 898 & 871 & 9140 & 372 \\
\hline D4B-LD-672 & 672 & & & & & 1.88 & 2.79 & $<32.5$ & 30100 & 11100 & 430 & 1120 & 1020 & 10750 & 434 \\
\hline D4B-LD-720 & 720 & & & & & 1.91 & 2.83 & $<32.5$ & 30000 & 11100 & 405 & 1050 & 969 & 10750 & 437 \\
\hline D4B-FD-CP & $\begin{array}{c}\text { Feed } \\
\text { Displacement }\end{array}$ & 1.74 & 2730 & 69500 & 844 & 1.20 & 1.74 & $<38.8$ & 18600 & 7200 & 277 & 673 & 896 & 6055 & 397 \\
\hline D4B-EL-CP & Elution & 25.9 & 58.7 & 1220 & 46.3 & $<0.05$ & $<0.05$ & $<39.8$ & 3630 & $<39.8$ & $<39.8$ & $<39.8$ & $<39.8$ & $<25.0$ & $<10.0$ \\
\hline Target & -- & 4.86 & 3280 & 93200 & 951 & 1.20 & 2.01 & 0 & 23100 & 9430 & 326 & 856 & 1210 & 7960 & 408 \\
\hline
\end{tabular}


Table B.24. Column D5 Test Analytical Data $\left(\mathrm{T}=25^{\circ} \mathrm{C}\right.$, Flow rate $\left.=10.62 \mathrm{~mL} / \mathrm{min}\right)$

\begin{tabular}{|c|c|c|c|c|c|c|c|c|c|c|c|c|c|c|c|}
\hline Sample ID & $\begin{array}{l}\text { Loading Time } \\
\text { (min) }\end{array}$ & $\begin{array}{c}\mathrm{Cs} \\
(\mathrm{mg} / \mathrm{kg})\end{array}$ & $\begin{array}{c}\mathrm{Al} \\
(\mathrm{mg} / \mathrm{kg})\end{array}$ & $\begin{array}{c}\mathrm{Na} \\
(\mathrm{mg} / \mathrm{kg})\end{array}$ & $\begin{array}{c}\mathrm{K} \\
(\mathrm{mg} / \mathrm{kg})\end{array}$ & $\begin{array}{c}\text { OH-Free } \\
\text { (meq/mL) }\end{array}$ & $\begin{array}{l}\text { OH-Total } \\
(\mathrm{meq} / \mathrm{mL})\end{array}$ & $\begin{array}{c}\mathrm{Cl} \\
(\mathrm{mg} / \mathrm{kg})\end{array}$ & $\begin{array}{c}\mathrm{NO}_{3} \\
(\mathrm{mg} / \mathrm{kg})\end{array}$ & $\begin{array}{c}\mathrm{NO}_{2} \\
(\mathrm{mg} / \mathrm{kg})\end{array}$ & $\begin{array}{c}\mathrm{PO}_{4} \\
(\mathrm{mg} / \mathrm{kg})\end{array}$ & $\begin{array}{c}\mathrm{SO}_{4} \\
(\mathrm{mg} / \mathrm{kg})\end{array}$ & $\begin{array}{c}\mathrm{C}_{2} \mathrm{O}_{4} \\
(\mathrm{mg} / \mathrm{kg})\end{array}$ & $\begin{array}{c}\text { TIC } \\
(\mathrm{mg} / \mathrm{kg})\end{array}$ & $\begin{array}{c}\text { TOC } \\
(\mathrm{mg} / \mathrm{kg})\end{array}$ \\
\hline D5-LD-00 & 0 & 5.07 & 3410 & 89300 & 1020 & 1.47 & 2.14 & $<32.7$ & 24500 & 8960 & 319 & 838 & 1020 & 7870 & 343 \\
\hline D5-LD-06 & 6 & 4.39 & 3380 & 85500 & 998 & 1.44 & 2.09 & $<32.7$ & 23600 & 8640 & 308 & 825 & 1140 & 7835 & 411 \\
\hline D5-LD-12 & 12 & 3.99 & 3200 & 77100 & 942 & 1.47 & 2.13 & $<32.9$ & 23000 & 8870 & 312 & 836 & 1190 & 6425 & 349 \\
\hline D5-LD-18 & 18 & 3.66 & 3420 & 78500 & 975 & 1.45 & 2.11 & $<32.8$ & 23500 & 8610 & 305 & 807 & 1140 & 7720 & 391 \\
\hline D5-LD-24 & 24 & 3.35 & 3390 & 85800 & 992 & 1.43 & 2.08 & $<33.3$ & 23300 & 8500 & 293 & 834 & 1150 & 7705 & 399 \\
\hline D5-LD-48 & 48 & 2.57 & 3400 & 86800 & 976 & 1.48 & 2.15 & $<26.8$ & 23600 & 9110 & 330 & 849 & 1150 & 6490 & 407 \\
\hline D5-LD-60 & 60 & 2.37 & 3460 & 88400 & 1020 & 1.42 & 2.08 & $<33.1$ & 23700 & 8620 & 324 & 827 & 1110 & 7695 & 394 \\
\hline D5-LD-80 & 80 & 2.00 & 3430 & 87000 & 1000 & 1.42 & 2.08 & $<32.8$ & 23500 & 8540 & 320 & 827 & 1140 & 7875 & 411 \\
\hline D5-LD-120 & 120 & 1.63 & 3490 & 79300 & 1010 & 1.44 & 2.09 & $<32.9$ & 22900 & 8790 & 308 & 817 & 1170 & 8035 & 396 \\
\hline D5-LD-180 & 180 & 1.29 & 3470 & 79800 & 1010 & 1.43 & 2.10 & $<33.0$ & 23400 & 8520 & 308 & 820 & 1140 & 7795 & 396 \\
\hline D5-LD-240 & 240 & 1.10 & 3360 & 83100 & 967 & 1.45 & 2.11 & $<33.0$ & 23400 & 8580 & 341 & 817 & 1160 & 7725 & 407 \\
\hline D5-FD-CP & $\begin{array}{c}\text { Feed } \\
\text { Displacement }\end{array}$ & 0.496 & 1900 & 50300 & 558 & 0.843 & 1.19 & $<36.8$ & 13100 & 4930 & 181 & 490 & 672 & 4085 & 249 \\
\hline Target & -- & 4.86 & 3280 & 93200 & 951 & 1.20 & 2.01 & 0 & 23100 & 9430 & 326 & 856 & 1210 & 7960 & 408 \\
\hline
\end{tabular}


Table B.25. Datasheet for $50^{\circ} \mathrm{C}$ Batch Loading Tests

\begin{tabular}{|c|c|c|c|c|c|c|c|c|c|c|c|}
\hline \multirow[b]{2}{*}{ Sample ID } & \multirow[b]{2}{*}{$\begin{array}{c}\text { Simulant ID } \\
\text { Used }\end{array}$} & \multicolumn{5}{|c|}{ Initial Concentrations } & \multicolumn{5}{|c|}{ Final Concentrations } \\
\hline & & Cs (mg/kg) & $\begin{array}{c}\mathrm{Na} \\
(\mathrm{mg} / \mathrm{kg})\end{array}$ & $\mathrm{K}(\mathrm{mg} / \mathrm{kg})$ & $\begin{array}{l}\mathrm{OH} \\
(\mathrm{M}) \\
\end{array}$ & $\begin{array}{c}\mathrm{NO}_{3} \\
(\mathrm{mg} / \mathrm{kg})\end{array}$ & Cs (mg/kg) & $\begin{array}{c}\mathrm{Na} \\
(\mathrm{mg} / \mathrm{kg})\end{array}$ & $\mathrm{K}(\mathrm{mg} / \mathrm{kg})$ & $\begin{array}{l}\mathrm{OH} \\
(\mathrm{M}) \\
\end{array}$ & $\begin{array}{c}\mathrm{NO}_{3} \\
(\mathrm{mg} / \mathrm{kg})\end{array}$ \\
\hline Test-5-Na-LL-1 & $1 \mathrm{~A}$ & 0.679 & 2340 & 193 & 0.101 & 72.3 & 0.0100 & 2370 & 137 & 0.0947 & 72.2 \\
\hline Test-5-Na-LL-2 & $2 \mathrm{~A}$ & 0.653 & 11300 & 191 & 0.100 & 5280 & 0.0184 & 11400 & 172 & 0.0953 & 5480 \\
\hline Test-5-Na-LL-3 & $3 \mathrm{~A}$ & 0.677 & 16400 & 193 & 0.100 & 8640 & 0.0266 & 17000 & 179 & 0.0950 & 8670 \\
\hline Test-5-Na-LL-4 & $4 \mathrm{~A}$ & 0.631 & 21600 & 189 & 0.100 & 12000 & 0.0301 & 22500 & 181 & 0.0951 & 12100 \\
\hline Test-5-Na-LL-5 & $5 \mathrm{~A}$ & 0.481 & 47800 & 148 & 0.101 & 36600 & 0.0775 & 61200 & 188 & 0.0941 & 36700 \\
\hline Test-5-Na-LL-6 & $6 \mathrm{~A}$ & 0.580 & 90200 & 442 & 0.100 & 55200 & 0.132 & 92300 & 448 & 0.0931 & 54600 \\
\hline Test-5-Na-MM-1 & $7 \mathrm{~A}$ & 0.657 & 2310 & 1870 & 0.101 & 687 & 0.0474 & 2490 & 1670 & 0.0966 & 696 \\
\hline Test-5-Na-MM-2 & $8 \mathrm{~A}$ & 0.656 & 11300 & 1880 & 0.100 & 5910 & 0.0633 & 11700 & 1850 & 0.0958 & 6020 \\
\hline Test-5-Na-MM-3 & $9 \mathrm{~A}$ & 0.658 & 16300 & 1880 & 0.101 & 9080 & 0.0757 & 17400 & 1870 & 0.0958 & 9110 \\
\hline Test-5-Na-MM-4 & $10 \mathrm{~A}$ & 0.643 & 21900 & 1900 & 0.101 & 12500 & 0.0801 & 22600 & 1850 & 0.0957 & 12500 \\
\hline Test-5-Na-MM-5 & $11 \mathrm{~A}$ & 0.607 & 58300 & 1810 & 0.100 & 36600 & 0.136 & 61200 & 1890 & 0.0942 & 36900 \\
\hline Test-5-Na-MM-6 & $12 \mathrm{~A}$ & 0.659 & 107000 & 2080 & 0.0997 & 55200 & 0.176 & 93000 & 1780 & 0.0928 & 55100 \\
\hline Test-5-Na-NN-1 & $13 \mathrm{~A}$ & 0.738 & 21600 & 199 & 0.993 & 71.6 & 0.0388 & 22600 & 185 & 0.983 & 70.9 \\
\hline Test-5-Na-NN-2 & $14 \mathrm{~A}$ & 0.030 & 59400 & 191 & 0.988 & 25100 & $<0.00879$ & 59500 & 188 & 0.978 & 25300 \\
\hline Test-5-Na-NN-3 & $15 \mathrm{~A}$ & 0.596 & 92100 & 181 & 0.993 & 46000 & 0.118 & 84300 & 185 & 0.978 & 46800 \\
\hline Test-5-Na-OO-1 & $16 \mathrm{~A}$ & 0.793 & 21600 & 1890 & 0.993 & 659 & 0.0890 & 22500 & 1870 & 0.978 & 662 \\
\hline Test-5-Na-OO-2 & $17 \mathrm{~A}$ & 0.613 & 58400 & 1840 & 0.993 & 25800 & 0.134 & 60800 & 1870 & 0.978 & 25900 \\
\hline Test-5-Na-OO-3 & $18 \mathrm{~A}$ & 0.604 & 90500 & 1720 & 0.993 & 47200 & 0.198 & 93500 & 1780 & 0.972 & 47300 \\
\hline Test-5-Na-I-1 & 19 & 63.6 & 2300 & 186 & 0.0984 & 73.7 & 3.20 & 2350 & 144 & 0.0965 & 71.3 \\
\hline Test-5-Na-I-2 & 20 & 64.9 & 10700 & 180 & 0.0983 & 5680 & 9.52 & 10600 & 166 & 0.0910 & 5850 \\
\hline Test-5-Na-I-3 & 21 & 63.0 & 16400 & 193 & 0.0990 & 8210 & 12.2 & 16400 & 188 & 0.0937 & 8240 \\
\hline Test-5-Na-I-4 & 22 & 63.6 & 22200 & 187 & 0.0985 & 10800 & 14.9 & 21500 & 180 & 0.0904 & 11300 \\
\hline Test-5-Na-I-5 & 23 & 57.9 & 59200 & 178 & 0.0988 & 35500 & 26.8 & 58200 & 172 & 0.0921 & 35300 \\
\hline Test-5-Na-I-6 & 24 & 53.3 & 89100 & 164 & 0.0985 & 55000 & 31.2 & 90500 & 166 & 0.0937 & 54600 \\
\hline Test-5-Na-J-1 & 25 & 68.6 & 2270 & 1920 & 0.0980 & 649 & 9.05 & 2470 & 1600 & 0.0965 & 693 \\
\hline Test-5-Na-J-2 & 26 & 64.4 & 10800 & 1840 & 0.0955 & 6190 & 14.2 & 10800 & 1770 & 0.0904 & 6430 \\
\hline Test-5-Na-J-3 & 27 & 66.4 & 16400 & 1910 & 0.0974 & 8660 & 16.8 & 16400 & 1780 & 0.0953 & 8750 \\
\hline
\end{tabular}


Table B.25. (contd)

\begin{tabular}{|c|c|c|c|c|c|c|c|c|c|c|c|}
\hline \multirow[b]{2}{*}{ Sample ID } & \multirow[b]{2}{*}{$\begin{array}{l}\text { Simulant ID } \\
\text { Used }\end{array}$} & \multicolumn{5}{|c|}{ Initial Concentrations } & \multicolumn{5}{|c|}{ Final Concentrations } \\
\hline & & Cs (mg/kg) & $\begin{array}{c}\mathrm{Na} \\
(\mathrm{mg} / \mathrm{kg})\end{array}$ & $\mathrm{K}(\mathrm{mg} / \mathrm{kg})$ & $\begin{array}{l}\mathrm{OH} \\
(\mathrm{M})\end{array}$ & $\begin{array}{c}\mathrm{NO}_{3} \\
(\mathrm{mg} / \mathrm{kg})\end{array}$ & Cs (mg/kg) & $\begin{array}{c}\mathrm{Na} \\
(\mathrm{mg} / \mathrm{kg})\end{array}$ & $\mathrm{K}(\mathrm{mg} / \mathrm{kg})$ & $\begin{array}{l}\mathrm{OH} \\
(\mathrm{M})\end{array}$ & $\begin{array}{c}\mathrm{NO}_{3} \\
(\mathrm{mg} / \mathrm{kg})\end{array}$ \\
\hline Test-5-Na-J-4 & 28 & 64.5 & 21100 & 1860 & 0.0988 & 11700 & 18.9 & 21500 & 1750 & 0.0950 & 11800 \\
\hline Test-5-Na-J-5 & 29 & 60.1 & 58400 & 1810 & 0.0985 & 34700 & 27.0 & 57800 & 1730 & 0.0936 & 34100 \\
\hline Test-5-Na-J-6 & 30 & 56.0 & 90700 & 1810 & 0.0976 & 53800 & 32.5 & 91000 & 1700 & 0.0927 & 54500 \\
\hline Test-5-Na-K-1 & 31 & 68.0 & 22200 & 193 & 0.969 & 97.7 & 10.0 & 21800 & 171 & 0.983 & 65.3 \\
\hline Test-5-Na-K-2 & 32 & 61.5 & 59800 & 195 & 0.985 & 23600 & 23.1 & 60100 & 188 & 0.983 & 24000 \\
\hline Test-5-Na-K-3 & 33 & 54.6 & 88700 & 170 & 0.995 & 45100 & 27.4 & 89400 & 170 & 0.974 & 45300 \\
\hline Test-5-Na-L-1 & 34 & 66.5 & 22100 & 1940 & 0.986 & 629 & 14.6 & 21400 & 1810 & 0.988 & 665 \\
\hline Test-5-Na-L-2 & 35 & 60.2 & 58500 & 1810 & 0.986 & 24400 & 24.5 & 58700 & 1790 & 0.983 & 24100 \\
\hline Test-5-Na-L-3 & 36 & 54.5 & 87900 & 1670 & 0.995 & 46200 & 28.8 & 88500 & 1670 & 0.974 & 44600 \\
\hline Test-5-Na-Q-1 & 37 & 67.5 & 2280 & 186 & 0.0982 & 90.2 & 3.00 & 2270 & 145 & 0.0850 & 69.9 \\
\hline Test-5-Na-Q-2 & 38 & 58.8 & 11000 & 183 & 0.0988 & 5660 & 7.62 & 11100 & 176 & 0.0968 & 5580 \\
\hline Test-5-Na-Q-3 & 39 & 67.5 & 16600 & 190 & 0.0981 & 8110 & 12.6 & 16900 & 189 & 0.0953 & 8180 \\
\hline Test-5-Na-Q-4 & 40 & 65.6 & 22000 & 189 & 0.0984 & 11100 & 14.8 & 21600 & 183 & 0.0953 & 11200 \\
\hline Test-5-Na-Q-5 & 41 & 53.8 & 58000 & 197 & 0.0980 & 33900 & 22.1 & 57400 & 191 & 0.0939 & 33700 \\
\hline Test-5-Na-Q-6 & 42 & 59.0 & 89300 & 178 & 0.0974 & 53600 & 33.2 & 89300 & 175 & 0.0934 & 54000 \\
\hline Test-5-Na-R-1 & 43 & 71.1 & 2270 & 1900 & 0.0986 & 656 & 10.6 & 2360 & 1690 & 0.0971 & 693 \\
\hline Test-5-Na-R-2 & 44 & 79.0 & 10700 & 1840 & 0.0951 & 6310 & 18.6 & 11000 & 1790 & 0.0925 & 6180 \\
\hline Test-5-Na-R-3 & 45 & 65.4 & 16600 & 1930 & 0.0984 & 8710 & 17.4 & 16600 & 1840 & 0.0961 & 8730 \\
\hline Test-5-Na-R-4 & 46 & 66.7 & 21700 & 1890 & 0.0985 & 11700 & 20.4 & 21500 & 1850 & 0.0943 & 11700 \\
\hline Test-5-Na-R-5 & 47 & 69.5 & 58600 & 1840 & 0.0978 & 34700 & 34.2 & 58500 & 1820 & 0.0946 & 33900 \\
\hline Test-5-Na-R-6 & 48 & 59.0 & 89600 & 1740 & 0.0977 & 53900 & 28.1 & 87500 & 1720 & 0.0937 & 54700 \\
\hline Test-5-Na-S-1 & 49 & 65.9 & 21900 & 187 & 0.988 & 68.1 & 8.47 & 21700 & 164 & 0.972 & 68.1 \\
\hline Test-5-Na-S-2 & 50 & 66.2 & 58200 & 204 & 0.988 & 23400 & 23.3 & 58800 & 198 & 0.983 & 23400 \\
\hline Test-5-Na-S-3 & 51 & 55.8 & 87900 & 174 & 0.989 & 46300 & 28.5 & 90100 & 174 & 0.979 & 42700 \\
\hline Test-5-Na-T-1 & 52 & 63.3 & 21500 & 1920 & 0.993 & 624 & 12.7 & 21500 & 1800 & 0.983 & 655 \\
\hline Test-5-Na-T-2 & 53 & 60.2 & 57500 & 1750 & 0.995 & 25900 & 24.5 & 58800 & 1750 & 0.984 & 23300 \\
\hline Test-5-Na-T-3 & 54 & 53.6 & 88600 & 1660 & 0.995 & 47200 & 28.4 & 89200 & 1690 & 0.979 & 42600 \\
\hline
\end{tabular}


Table B.25. (contd)

\begin{tabular}{|c|c|c|c|c|c|c|c|c|c|c|c|}
\hline \multirow[b]{2}{*}{ Sample ID } & \multirow[b]{2}{*}{$\begin{array}{l}\text { Simulant ID } \\
\text { Used }\end{array}$} & \multicolumn{5}{|c|}{ Initial Concentrations } & \multicolumn{5}{|c|}{ Final Concentrations } \\
\hline & & Cs (mg/kg) & $\begin{array}{c}\mathrm{Na} \\
(\mathrm{mg} / \mathrm{kg})\end{array}$ & K (mg/kg) & $\begin{array}{l}\mathrm{OH} \\
(\mathrm{M})\end{array}$ & $\begin{array}{c}\mathrm{NO}_{3} \\
(\mathrm{mg} / \mathrm{kg})\end{array}$ & Cs (mg/kg) & $\begin{array}{c}\mathrm{Na} \\
(\mathrm{mg} / \mathrm{kg})\end{array}$ & $\mathrm{K}(\mathrm{mg} / \mathrm{kg})$ & $\begin{array}{l}\mathrm{OH} \\
(\mathrm{M})\end{array}$ & $\begin{array}{c}\mathrm{NO}_{3} \\
(\mathrm{mg} / \mathrm{kg})\end{array}$ \\
\hline Test-5-Na-Y-1 & 55 & 647 & 2230 & 190 & 0.101 & 134 & 159 & 2340 & 160 & 0.0978 & 131 \\
\hline Test-5-Na-Y-2 & 56 & 637 & 10800 & 179 & 0.0945 & 5750 & 317 & 11000 & 171 & 0.0898 & 5660 \\
\hline Test-5-Na-Y-3 & 57 & 637 & 16600 & 195 & 0.101 & 8050 & 340 & 16700 & 185 & 0.0964 & 8250 \\
\hline Test-5-Na-Y-4 & 58 & 617 & 21400 & 186 & 0.101 & 11100 & 358 & 21700 & 181 & 0.0960 & 11100 \\
\hline Test-5-Na-Y-5 & 59 & 578 & 58000 & 189 & 0.100 & 34300 & 420 & 57700 & 181 & 0.0944 & 34000 \\
\hline Test-5-Na-Y-6 & 60 & 536 & 89600 & 183 & 0.100 & 53500 & 424 & 88600 & 178 & 0.0932 & 52200 \\
\hline Test-5-Na-Z-1 & 61 & 651 & 2170 & 1880 & 0.0986 & 713 & 258 & 2370 & 1690 & 0.0955 & 748 \\
\hline Test-5-Na-Z-2 & 62 & 629 & 10800 & 1860 & 0.0990 & 6330 & 350 & 11300 & 1840 & 0.0905 & 6240 \\
\hline Test-5-Na-Z-3 & 63 & 639 & 16300 & 1930 & 0.101 & 8810 & 359 & 16200 & 1790 & 0.0960 & 8620 \\
\hline Test-5-Na-Z-4 & 64 & 622 & 21500 & 1950 & 0.101 & 11600 & 385 & 21200 & 1840 & 0.0969 & 11700 \\
\hline Test-5-Na-Z-5 & 65 & 560 & 58000 & 1850 & 0.100 & 34700 & 405 & 57600 & 1780 & 0.0942 & 34600 \\
\hline Test-5-Na-Z-6 & 66 & 519 & 89600 & 1780 & 0.100 & 54000 & 430 & 89600 & 1710 & 0.0940 & 53200 \\
\hline Test-5-Na-AA-1 & 67 & 629 & 21100 & 192 & 0.993 & 129 & 297 & 22900 & 197 & 0.978 & 123 \\
\hline Test-5-Na-AA-2 & 68 & 574 & 57600 & 189 & 0.983 & 23300 & 500 & 75200 & 235 & 0.972 & 23600 \\
\hline Test-5-Na-AA-3 & 69 & 521 & 88300 & 183 & 0.989 & 46200 & 391 & 86200 & 178 & 0.979 & 44100 \\
\hline Test-5-Na-BB-1 & 70 & 628 & 21200 & 1910 & 0.988 & 712 & 330 & 23000 & 1970 & 0.983 & 719 \\
\hline Test-5-Na-BB-2 & 71 & 562 & 52800 & 1740 & 0.995 & 25600 & 404 & 56900 & 1700 & 0.979 & 24100 \\
\hline Test-5-Na-BB-3 & 72 & 528 & 88700 & 1690 & 0.995 & 47300 & 408 & 86300 & 1630 & 0.979 & 44500 \\
\hline
\end{tabular}


Table B.26. Datasheet for $25^{\circ} \mathrm{C}$ Batch Loading Tests

\begin{tabular}{|c|c|c|c|c|c|c|c|c|c|c|c|}
\hline \multirow[b]{2}{*}{ Sample ID } & \multirow[b]{2}{*}{$\begin{array}{c}\text { Simulant ID } \\
\text { Used }\end{array}$} & \multicolumn{5}{|c|}{ Initial Concentrations } & \multicolumn{5}{|c|}{ Final Concentrations } \\
\hline & & Cs (mg/kg) & $\begin{array}{c}\mathrm{Na} \\
(\mathrm{mg} / \mathrm{kg})\end{array}$ & $\mathrm{K}(\mathrm{mg} / \mathrm{kg})$ & $\begin{array}{l}\mathrm{OH} \\
(\mathrm{M}) \\
\end{array}$ & $\begin{array}{c}\mathrm{NO}_{3} \\
(\mathrm{mg} / \mathrm{kg}) \\
\end{array}$ & Cs (mg/kg) & $\begin{array}{c}\mathrm{Na} \\
(\mathrm{mg} / \mathrm{kg})\end{array}$ & $\mathrm{K}(\mathrm{mg} / \mathrm{kg})$ & $\begin{array}{l}\mathrm{OH} \\
(\mathrm{M}) \\
\end{array}$ & $\mathrm{NO}_{3}(\mathrm{mg} / \mathrm{kg})$ \\
\hline Test-5-Na-QQ-1 & $1 \mathrm{~A}$ & 0.679 & 2340 & 193 & 0.101 & 72.3 & $<0.00997$ & 2260 & 132 & 0.0969 & 71.6 \\
\hline Test-5-Na-QQ-2 & $2 \mathrm{~A}$ & 0.653 & 11300 & 191 & 0.100 & 5280 & 0.0183 & 11000 & 167 & 0.0955 & 5330 \\
\hline Test-5-Na-QQ-3 & $3 \mathrm{~A}$ & 0.677 & 16400 & 193 & 0.100 & 8640 & 0.0178 & 16600 & 171 & 0.0948 & 8490 \\
\hline Test-5-Na-QQ-4 & $4 \mathrm{~A}$ & 0.631 & 21600 & 189 & 0.100 & 12000 & 0.0214 & 22100 & 181 & 0.0945 & 11700 \\
\hline Test-5-Na-QQ-5 & $5 \mathrm{~A}$ & 0.481 & 47800 & 148 & 0.101 & 36600 & 0.0345 & 59300 & 183 & 0.0937 & 41900 \\
\hline Test-5-Na-QQ-6 & $6 \mathrm{~A}$ & 0.580 & 90200 & 442 & 0.100 & 55200 & 0.0658 & 92200 & 438 & 0.0921 & 67700 \\
\hline Test-5-Na-RR-1 & $7 \mathrm{~A}$ & 0.657 & 2310 & 1870 & 0.101 & 687 & 0.0284 & 2390 & 1620 & 0.0863 & 853 \\
\hline Test-5-Na-RR-2 & $8 \mathrm{~A}$ & 0.656 & 11300 & 1880 & 0.100 & 5910 & 0.0386 & 11000 & 1770 & 0.0951 & 5690 \\
\hline Test-5-Na-RR-3 & $9 \mathrm{~A}$ & 0.658 & 16300 & 1880 & 0.101 & 9080 & 0.0381 & 16500 & 1780 & 0.0942 & 9060 \\
\hline Test-5-Na-RR-4 & $10 \mathrm{~A}$ & 0.643 & 21900 & 1900 & 0.101 & 12500 & 0.0530 & 22200 & 1830 & 0.0945 & 12600 \\
\hline Test-5-Na-RR-5 & $11 \mathrm{~A}$ & 0.607 & 58300 & 1810 & 0.100 & 36600 & 0.0745 & 58100 & 1780 & 0.0928 & 36000 \\
\hline Test-5-Na-RR-6 & $12 \mathrm{~A}$ & 0.659 & 107000 & 2080 & 0.0997 & 55200 & 0.0931 & 89300 & 1670 & 0.0920 & 54600 \\
\hline Test-5-Na-SS-1 & $13 \mathrm{~A}$ & 0.738 & 21600 & 199 & 0.993 & 71.6 & 0.0196 & 21600 & 174 & 0.983 & 72.4 \\
\hline Test-5-Na-SS-2 & $14 \mathrm{~A}$ & 0.030 & 59400 & 191 & 0.988 & 25100 & $<0.00878$ & 59300 & 184 & 0.972 & 24800 \\
\hline Test-5-Na-SS-3 & $15 \mathrm{~A}$ & 0.596 & 92100 & 181 & 0.993 & 46000 & 0.0696 & 89800 & 177 & 0.978 & 46300 \\
\hline Test-5-Na-TT-1 & $16 \mathrm{~A}$ & 0.793 & 21600 & 1890 & 0.993 & 659 & 0.0689 & 22200 & 1820 & 0.983 & 661 \\
\hline Test-5-Na-TT-2 & $17 \mathrm{~A}$ & 0.613 & 58400 & 1840 & 0.993 & 25800 & 0.0655 & 58300 & 1800 & 0.993 & 25600 \\
\hline Test-5-Na-TT-3 & $18 \mathrm{~A}$ & 0.604 & 90500 & 1720 & 0.993 & 47200 & 0.0929 & 90400 & 1760 & 0.978 & 46400 \\
\hline Test-5-Na-M-1 & 19 & 63.6 & 2300 & 186 & 0.0984 & 73.7 & 2.16 & 2300 & 136 & 0.0861 & 70.7 \\
\hline Test-5-Na-M-2 & 20 & 64.9 & 10700 & 180 & 0.0983 & 5680 & 7.03 & 10900 & 173 & 0.0917 & 5510 \\
\hline Test-5-Na-M-3 & 21 & 63.0 & 16400 & 193 & 0.0990 & 8210 & 8.00 & 17000 & 183 & 0.0952 & 8130 \\
\hline Test-5-Na-M-4 & 22 & 63.6 & 22200 & 187 & 0.0985 & 10800 & 10.5 & 21900 & 176 & 0.0901 & 11200 \\
\hline Test-5-Na-M-5 & 23 & 57.9 & 59200 & 178 & 0.0988 & 35500 & 18.5 & 58300 & 173 & 0.0925 & 35300 \\
\hline Test-5-Na-M-6 & 24 & 53.3 & 89100 & 164 & 0.0985 & 55000 & 25.1 & 90200 & 172 & 0.0937 & 54500 \\
\hline Test-5-Na-N-1 & 25 & 68.6 & 2270 & 1920 & 0.0980 & 649 & 6.35 & 2470 & 1610 & 0.0955 & 718 \\
\hline Test-5-Na-N-2 & 26 & 64.4 & 10800 & 1840 & 0.0955 & 6190 & 12.4 & 11000 & 1740 & 0.0953 & 6070 \\
\hline
\end{tabular}


Table B.26. (contd)

\begin{tabular}{|c|c|c|c|c|c|c|c|c|c|c|c|}
\hline \multirow[b]{2}{*}{ Sample ID } & \multirow[b]{2}{*}{$\begin{array}{c}\text { Simulant ID } \\
\text { Used }\end{array}$} & \multicolumn{5}{|c|}{ Initial Concentrations } & \multicolumn{5}{|c|}{ Final Concentrations } \\
\hline & & Cs (mg/kg) & $\begin{array}{c}\mathrm{Na} \\
(\mathrm{mg} / \mathrm{kg})\end{array}$ & K (mg/kg) & $\begin{array}{l}\mathrm{OH} \\
(\mathrm{M})\end{array}$ & $\begin{array}{c}\mathrm{NO}_{3} \\
(\mathrm{mg} / \mathrm{kg})\end{array}$ & Cs (mg/kg) & $\begin{array}{c}\mathrm{Na} \\
(\mathrm{mg} / \mathrm{kg})\end{array}$ & $\mathrm{K}(\mathrm{mg} / \mathrm{kg})$ & $\begin{array}{l}\mathrm{OH} \\
(\mathrm{M})\end{array}$ & $\mathrm{NO}_{3}(\mathrm{mg} / \mathrm{kg})$ \\
\hline Test-5-Na-N-3 & 27 & 66.4 & 16400 & 1910 & 0.0974 & 8660 & 10.6 & 16600 & 1790 & 0.0945 & 9010 \\
\hline Test-5-Na-N-4 & 28 & 64.5 & 21100 & 1860 & 0.0988 & 11700 & 12.1 & 22000 & 1820 & 0.0940 & 11800 \\
\hline Test-5-Na-N-5 & 29 & 60.1 & 58400 & 1810 & 0.0985 & 34700 & 21.0 & 59700 & 1780 & 0.0937 & 34800 \\
\hline Test-5-Na-N-6 & 30 & 56.0 & 90700 & 1810 & 0.0976 & 53800 & 25.8 & 91000 & 1730 & 0.0908 & 54400 \\
\hline Test-5-Na-O-1 & 31 & 68.0 & 22200 & 193 & 0.969 & 97.7 & 5.08 & 22100 & 166 & 0.983 & 70.4 \\
\hline Test-5-Na-O-2 & 32 & 61.5 & 59800 & 195 & 0.985 & 23600 & 13.8 & 59600 & 185 & 0.978 & 23200 \\
\hline Test-5-Na-O-3 & 33 & 54.6 & 88700 & 170 & 0.995 & 45100 & 21.1 & 89900 & 173 & 0.979 & 45400 \\
\hline Test-5-Na-P-1 & 34 & 66.5 & 22100 & 1940 & 0.986 & 629 & 9.70 & 22000 & 1760 & 0.983 & 680 \\
\hline Test-5-Na-P-2 & 35 & 60.2 & 58500 & 1810 & 0.986 & 24400 & 16.6 & 59500 & 1780 & 0.978 & 24000 \\
\hline Test-5-Na-P-3 & 36 & 54.5 & 87900 & 1670 & 0.995 & 46200 & 23.3 & 88500 & 1690 & 0.984 & 42600 \\
\hline Test-5-Na-U-1 & 37 & 67.5 & 2280 & 186 & 0.0982 & 90.2 & 2.06 & 2290 & 132 & 0.0963 & 76.8 \\
\hline Test-5-Na-U-2 & 38 & 58.8 & 11000 & 183 & 0.0988 & 5660 & 5.13 & 11100 & 174 & 0.0915 & 5610 \\
\hline Test-5-Na-U-3 & 39 & 67.5 & 16600 & 190 & 0.0981 & 8110 & 8.39 & 16900 & 180 & 0.0930 & 8030 \\
\hline Test-5-Na-U-4 & 40 & 65.6 & 22000 & 189 & 0.0984 & 11100 & 9.72 & 22100 & 183 & 0.0932 & 11100 \\
\hline Test-5-Na-U-5 & 41 & 53.8 & 58000 & 197 & 0.0980 & 33900 & 15.7 & 58700 & 188 & 0.0934 & 34000 \\
\hline Test-5-Na-U-6 & 42 & 59.0 & 89300 & 178 & 0.0974 & 53600 & 29.3 & 106000 & 199 & 0.0926 & 53500 \\
\hline Test-5-Na-V-1 & 43 & 71.1 & 2270 & 1900 & 0.0986 & 656 & 6.35 & 2300 & 1580 & 0.0957 & 709 \\
\hline Test-5-Na-V-2 & 44 & 79.0 & 10700 & 1840 & 0.0951 & 6310 & 14.1 & 11100 & 1760 & 0.0900 & 6090 \\
\hline Test-5-Na-V-3 & 45 & 65.4 & 16600 & 1930 & 0.0984 & 8710 & 11.7 & 16800 & 1820 & 0.0927 & 8650 \\
\hline Test-5-Na-V-4 & 46 & 66.7 & 21700 & 1890 & 0.0985 & 11700 & 15.3 & 22500 & 1860 & 0.0936 & 11500 \\
\hline Test-5-Na-V-5 & 47 & 69.5 & 58600 & 1840 & 0.0978 & 34700 & 26.7 & 58300 & 1780 & 0.0925 & 34900 \\
\hline Test-5-Na-V-6 & 48 & 59.0 & 89600 & 1740 & 0.0977 & 53900 & 21.7 & 91200 & 1710 & 0.0922 & 53700 \\
\hline Test-5-Na-W-1 & 49 & 65.9 & 21900 & 187 & 0.988 & 68.1 & 5.39 & 21300 & 163 & 0.972 & 67.0 \\
\hline Test-5-Na-W-2 & 50 & 66.2 & 58200 & 204 & 0.988 & 23400 & 18.1 & 57800 & 189 & 0.978 & 23300 \\
\hline Test-5-Na-W-3 & 51 & 55.8 & 87900 & 174 & 0.989 & 46300 & 21.8 & 90200 & 171 & 0.979 & 44400 \\
\hline Test-5-Na-X-1 & 52 & 63.3 & 21500 & 1920 & 0.993 & 624 & 8.67 & 21600 & 1770 & 0.983 & 651 \\
\hline Test-5-Na-X-2 & 53 & 60.2 & 57500 & 1750 & 0.995 & 25900 & 19.0 & 57900 & 1710 & 0.979 & 24400 \\
\hline
\end{tabular}


Table B.26. (contd)

\begin{tabular}{|c|c|c|c|c|c|c|c|c|c|c|c|}
\hline \multirow[b]{2}{*}{ Sample ID } & \multirow[b]{2}{*}{$\begin{array}{c}\text { Simulant ID } \\
\text { Used }\end{array}$} & \multicolumn{5}{|c|}{ Initial Concentrations } & \multicolumn{5}{|c|}{ Final Concentrations } \\
\hline & & Cs (mg/kg) & $\begin{array}{c}\mathrm{Na} \\
(\mathrm{mg} / \mathrm{kg}) \\
\end{array}$ & $\mathrm{K}(\mathrm{mg} / \mathrm{kg})$ & $\begin{array}{l}\mathrm{OH} \\
(\mathrm{M}) \\
\end{array}$ & $\begin{array}{c}\mathrm{NO}_{3} \\
(\mathrm{mg} / \mathrm{kg}) \\
\end{array}$ & Cs (mg/kg) & $\begin{array}{c}\mathrm{Na} \\
(\mathrm{mg} / \mathrm{kg})\end{array}$ & $\mathrm{K}(\mathrm{mg} / \mathrm{kg})$ & $\begin{array}{l}\mathrm{OH} \\
(\mathrm{M})\end{array}$ & $\mathrm{NO}_{3}(\mathrm{mg} / \mathrm{kg})$ \\
\hline Test-5-Na-X-3 & 54 & 53.6 & 88600 & 1660 & 0.995 & 47200 & 23.3 & 88700 & 1650 & 0.979 & 45100 \\
\hline Test-5-Na-CC-1 & 55 & 647 & 2230 & 190 & 0.101 & 134 & 158 & 2380 & 171 & 0.0972 & 127 \\
\hline Test-5-Na-CC-2 & 56 & 637 & 10800 & 179 & 0.0945 & 5750 & 284 & 11000 & 172 & 0.0949 & 5960 \\
\hline Test-5-Na-CC-3 & 57 & 637 & 16600 & 195 & 0.101 & 8050 & 326 & 16700 & 189 & 0.0951 & 8170 \\
\hline Test-5-Na-CC-4 & 58 & 617 & 21400 & 186 & 0.101 & 11100 & 345 & 22000 & 189 & 0.0947 & 11300 \\
\hline Test-5-Na-CC-5 & 59 & 578 & 58000 & 189 & 0.100 & 34300 & 387 & 59100 & 191 & 0.0950 & 34400 \\
\hline Test-5-Na-CC-6 & 60 & 536 & 89600 & 183 & 0.100 & 53500 & 396 & 91000 & 182 & 0.0945 & 53800 \\
\hline Test-5-Na-DD-1 & 61 & 651 & 2170 & 1880 & 0.0986 & 713 & 214 & 2360 & 1970 & 0.0953 & 752 \\
\hline Test-5-Na-DD-2 & 62 & 629 & 10800 & 1860 & 0.0990 & 6330 & 314 & 10500 & 1760 & 0.0948 & 6480 \\
\hline Test-5-Na-DD-3 & 63 & 639 & 16300 & 1930 & 0.101 & 8810 & 343 & 17100 & 1960 & 0.0962 & 8720 \\
\hline Test-5-Na-DD-4 & 64 & 622 & 21500 & 1950 & 0.101 & 11600 & 348 & 21200 & 1910 & 0.0947 & 11700 \\
\hline Test-5-Na-DD-5 & 65 & 560 & 58000 & 1850 & 0.100 & 34700 & 387 & 60100 & 1890 & 0.0944 & 33700 \\
\hline Test-5-Na-DD-6 & 66 & 519 & 89600 & 1780 & 0.100 & 54000 & 402 & 90800 & 1840 & 0.0943 & 53700 \\
\hline Test-5-Na-EE-1 & 67 & 629 & 21100 & 192 & 0.993 & 129 & 250 & 22000 & 191 & 0.983 & 123 \\
\hline Test-5-Na-EE-2 & 68 & 574 & 57600 & 189 & 0.983 & 23300 & 353 & 60700 & 193 & 0.983 & 23700 \\
\hline Test-5-Na-EE-3 & 69 & 521 & 88300 & 183 & 0.989 & 46200 & 377 & 86900 & 180 & 0.974 & 44900 \\
\hline Test-5-Na-FF-1 & 70 & 628 & 21200 & 1910 & 0.988 & 712 & 306 & 22000 & 1940 & 0.978 & 714 \\
\hline Test-5-Na-FF-2 & 71 & 562 & 52800 & 1740 & 0.995 & 25600 & 377 & 56400 & 1720 & 0.979 & 24800 \\
\hline Test-5-Na-FF-3 & 72 & 528 & 88700 & 1690 & 0.995 & 47300 & 400 & 87600 & 1680 & 0.979 & 46000 \\
\hline
\end{tabular}


Table B.27. Datasheet for $35^{\circ} \mathrm{C}$ Batch Loading Tests

\begin{tabular}{|c|c|c|c|c|c|c|c|c|c|c|c|}
\hline \multirow[b]{2}{*}{ Sample ID } & \multirow[b]{2}{*}{$\begin{array}{c}\text { Simulant ID } \\
\text { Used }\end{array}$} & \multicolumn{5}{|c|}{ Initial Concentrations } & \multicolumn{5}{|c|}{ Final Concentrations } \\
\hline & & Cs (mg/kg) & $\begin{array}{c}\mathrm{Na} \\
(\mathrm{mg} / \mathrm{kg})\end{array}$ & $\mathrm{K}(\mathrm{mg} / \mathrm{kg})$ & $\begin{array}{l}\mathrm{OH} \\
(\mathrm{M}) \\
\end{array}$ & $\begin{array}{c}\mathrm{NO}_{3} \\
(\mathrm{mg} / \mathrm{kg})\end{array}$ & Cs (mg/kg) & $\begin{array}{c}\mathrm{Na} \\
(\mathrm{mg} / \mathrm{kg})\end{array}$ & $\mathrm{K}(\mathrm{mg} / \mathrm{kg})$ & $\begin{array}{l}\mathrm{OH} \\
(\mathrm{M}) \\
\end{array}$ & $\mathrm{NO}_{3}(\mathrm{mg} / \mathrm{kg})$ \\
\hline Test-5-Na-GG-1 & 72 & 528 & 88700 & 1690 & 0.995 & 47300 & 389 & 86300 & 1650 & 0.982 & 46600 \\
\hline Test-5-Na-GG-2 & 54 & 53.6 & 88600 & 1660 & 0.995 & 47200 & 23.2 & 89800 & 1680 & 0.989 & 47200 \\
\hline Test-5-Na-GG-3 & 36 & 54.5 & 87900 & 1670 & 0.995 & 46200 & 26.0 & 89300 & 1680 & 0.979 & 46900 \\
\hline Test-5-Na-PP-1 & $18 \mathrm{~A}$ & 0.604 & 90500 & 1720 & 0.993 & 47200 & 0.120 & 90200 & 1730 & 0.978 & 46800 \\
\hline Test-5-Na-HH-1 & 69 & 521 & 88300 & 183 & 0.989 & 46200 & 370 & 88900 & 180 & 0.979 & 46200 \\
\hline Test-5-Na-HH-2 & 51 & 55.8 & 87900 & 174 & 0.989 & 46300 & 25.0 & 88700 & 171 & 0.984 & 46100 \\
\hline Test-5-Na-HH-3 & 33 & 54.6 & 88700 & 170 & 0.995 & 45100 & 23.1 & 89100 & 167 & 0.979 & 45800 \\
\hline Test-5-Na-PP-2 & $15 \mathrm{~A}$ & 0.596 & 92100 & 181 & 0.993 & 46000 & 0.0668 & 90600 & 175 & 0.983 & 46400 \\
\hline Test-5-Na-II-1 & 62 & 629 & 10800 & 1860 & 0.0990 & 6330 & 306 & 10700 & 1760 & 0.0948 & 6300 \\
\hline Test-5-Na-II-2 & 44 & 79.0 & 10700 & 1840 & 0.0951 & 6310 & 17.1 & 11100 & 1780 & 0.0917 & 6260 \\
\hline Test-5-Na-II-3 & 26 & 64.4 & 10800 & 1840 & 0.0955 & 6190 & 12.9 & 10900 & 1770 & 0.0905 & 6260 \\
\hline Test-5-Na-PP-3 & $8 \mathrm{~A}$ & 0.656 & 11300 & 1880 & 0.100 & 5910 & 0.0490 & 11000 & 1770 & 0.0954 & 6030 \\
\hline Test-5-Na-JJ-1 & 56 & 637 & 10800 & 179 & 0.0945 & 5750 & 286 & 10900 & 167 & 0.0894 & 5750 \\
\hline Test-5-Na-JJ-2 & 38 & 58.8 & 11000 & 183 & 0.0988 & 5660 & 5.40 & 10800 & 166 & 0.0884 & 5690 \\
\hline Test-5-Na-JJ-3 & 20 & 64.9 & 10700 & 180 & 0.0983 & 5680 & 6.97 & 10900 & 168 & 0.0880 & 5730 \\
\hline Test-5-Na-PP-4 & $2 \mathrm{~A}$ & 0.653 & 11300 & 191 & 0.100 & 5280 & 0.0192 & 11100 & 170 & 0.0963 & 5450 \\
\hline Test-5-Na-KK-1 & 53 & 60.2 & 57500 & 1750 & 0.995 & 25900 & 20.5 & 56700 & 1700 & 0.979 & 25300 \\
\hline Test-5-Na-KK-2 & 71 & 562 & 52800 & 1740 & 0.995 & 25600 & 381 & 57900 & 1730 & 0.984 & 25600 \\
\hline
\end{tabular}



PNNL-21645

WTP-RPT-223, Rev 0

\section{Distribution*}

No. of

Copies

6 Bechtel National, Inc.

SM Barnes

FW Damerow

DL Herting

JL Meehan

DJ Sherwood

WTP R\&T Docs
H4-02

H4-02

H4-02

H4-02

$\mathrm{H} 4-02$

H4-02
No. of

Copies

5 Battelle-Pacific Northwest National Laboratory

GN Brown

P7-25

RA Peterson

P7-22

DE Rinehart

RL Russell

K6-24

Project File

Information Release (pdf)
K6-24

K3-52

*All distribution will be made electronically. 




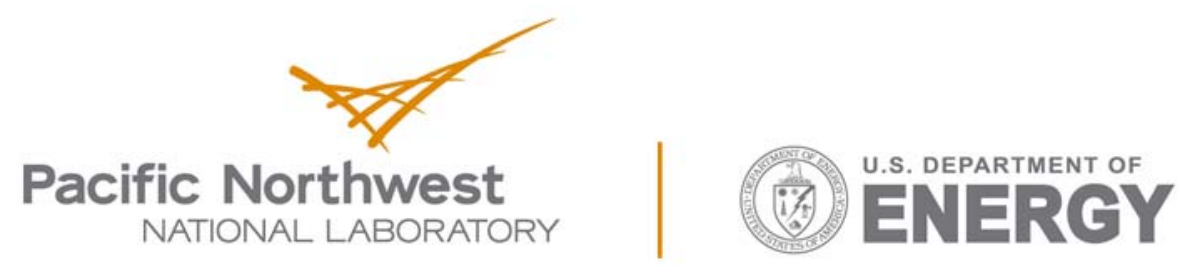

Proudly Operated by Battelle Since 1965

902 Battelle Boulevard

P.O. Box 999

Richland, WA 99352

1-888-375-PNNL (7665)

www.pnnl.gov 